\title{
HERANÇA DA REAÇÃO DE Capsicum spp. AO OÍDIO (Leveillula taurica (LEV.) ARN.)
}

\section{SALLY FERREIRA BLAT}

\author{
Tese apresentada à Escola Superior de \\ Agricultura "Luiz de Queiroz", \\ Universidade de São Paulo, para obtenção \\ do Título de Doutor em Agronomia, Área \\ de Concentração: Fitotecnia.
}

P I R A C I C A B A

Estado de São Paulo - Brasil

Fevereiro - 2004 


\title{
HERANÇA DA REAÇÃO DE Capsicum spp. AO OÍDIO (Leveillula taurica (LEV.) ARN.)
}

\author{
SALLY FERREIRA BLAT \\ Engenheira Agrônoma
}

Orientador: Prof. Dr. CYRO PAULINO DA COSTA

\begin{abstract}
Tese apresentada à Escola Superior de Agricultura "Luiz de Queiroz" Universidade de São Paulo, para obtenção do Título de Doutor em Agronomia, Área de Concentração: Fitotecnia.
\end{abstract}

P I R A C I C A B A

Estado de São Paulo - Brasil

Fevereiro - 2004 


\title{
Dados Internacionais de Catalogação na Publicação (CIP)
} DIVISÃO DE BIBLIOTECA E DOCUMENTAÇÃO - ESALQ/USP

\author{
Blat, Sally Ferreira \\ Herança da reação de Capsicum spp. ao oídio (Leveillula taurica (Lev.) Arn.) / \\ Sally Ferreira Blat. - - Piracicaba, 2004. \\ 153 p. : il. \\ Tese (doutorado) - Escola Superior de Agricultura Luiz de Queiroz, 2004. \\ Bibliografia. \\ 1. Oídio 2. Pimenta 3. Pimentão 4. Resistência genética vegetal I. Título
}

CDD 635.643

\section{"Permitida a cópia total ou parcial deste documento, desde que citada a fonte - $\mathrm{O}$ autor"}


Aos meus pais Maria Helena e Salvador

Pela dedicação, incentivo e confiança

A minha irmã Katy e meu cunhado Brito

Pelo carinho em todos os momentos

\section{Ofereço}

Ao meu marido Julio Cesar,

Pela compreensão, apoio e amor

Dedico 


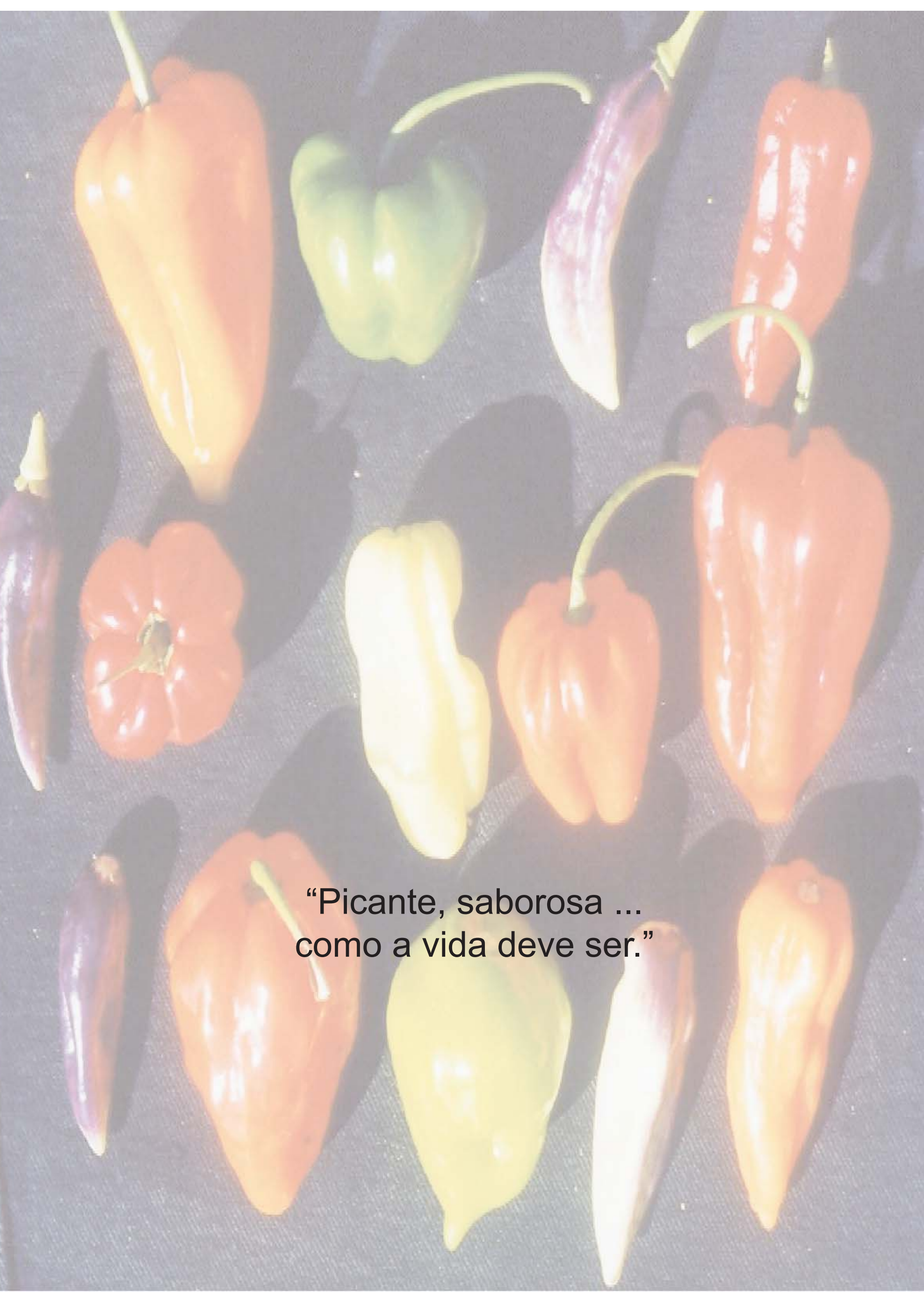




\section{AGRADECIMENTOS}

À Deus, por ser generoso nas minhas conquistas;

À Escola Superior de Agricultura "Luiz de Queiroz", pela oportunidade de aperfeiçoamento;

À FAPESP, pelo suporte financeiro e concessão da bolsa de doutorado;

Ao Prof. Dr. Cyro Paulino da Costa, pela valiosa orientação, amizade e paciência, as quais jamais serão esquecidas. Tenho a honra de ter sido sua orientada;

Ao Prof. Dr. Roland Vencovsky, pelos seus preciosos ensinamentos, auxílio nas análises e amizade, minha sincera gratidão e admiração;

Ao Fernando C. Sala (Gambé), pelo convívio, apoio e ajuda prestada durante o desenvolvimento da pesquisa;

A minha grande amiga Silvana C. S. Bueno, pelo companheirismo, horas de descontração e carinho;

A todos os meus colegas, em especial, Valéria, Cecília, Sergio e Marcelo Bregagnholi, pelo carinho;

À amiga Juliana Boscariol, pelo apoio em todos os momentos;

Aos professores, funcionários e secretárias do Departamento de Produção Vegetal e do curso de Fitotecnia, especialmente Helena, Célia e Bete, pela colaboração durante o curso;

A secretária de pós-graduação em Fitotecnia, Luciane, pela atenção especial e auxílio; Aos funcionários temporários, Rogério, Donizete, Francisco e Miguel, pelo auxílio nos experimentos;

Aos funcionários da biblioteca, pelo atendimento prestado;

A todos que tive a oportunidade de conhecer e conviver e que direta ou indiretamente contribuíram para a realização deste trabalho. 


\section{SUMÁRIO}

Página

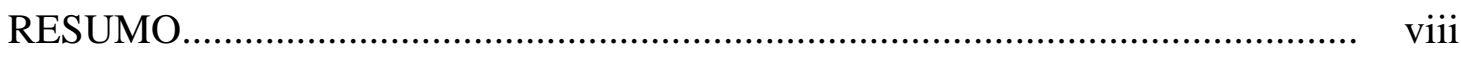

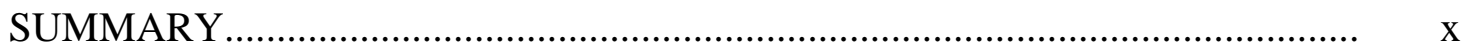

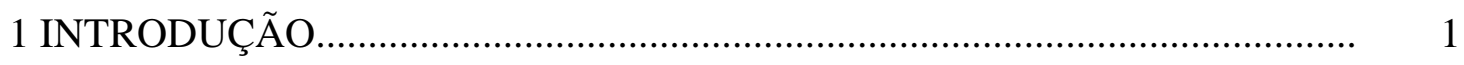

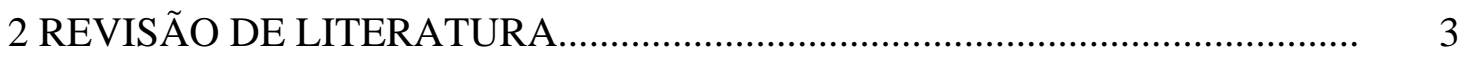

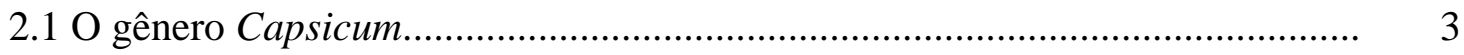

2.2 Importância e ocorrência do oídio (Leveillula taurica)................................... 4

2.3 Sintomatologia e caracterização................................................................. 5

2.4 Herança e ocorrência de resistência a Leveillula taurica em Capsicum............ 9

3 HERANÇA DA REAÇÃO DE Capsicum annuum AO OÍDIO.......................... 14

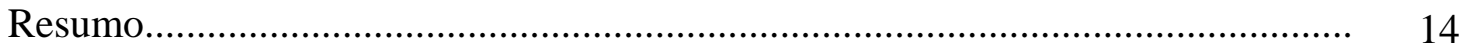

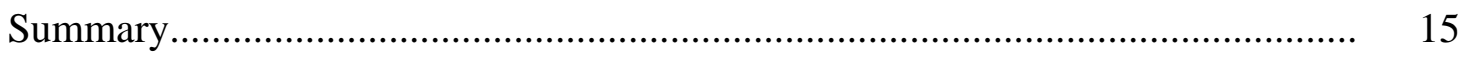

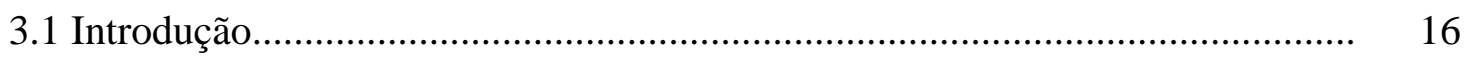

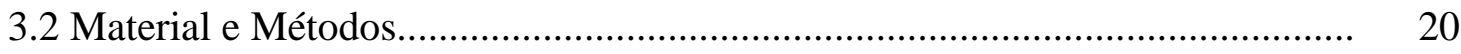

3.3 Resultados e Discussão....................................................................... 35

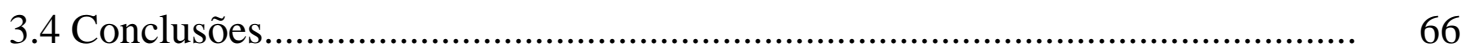

4 HERANÇA DA REAÇÃO DE Capsicum baccatum AO OÍDIO........................ 67

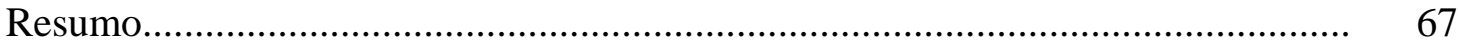

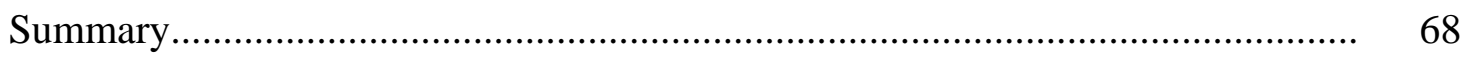

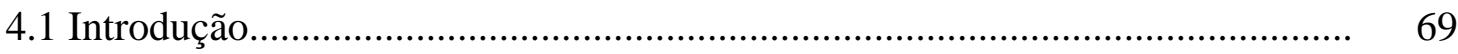


4.2 Material e Métodos.........................................................................................

4.3 Resultados e Discussão................................................................................ 82

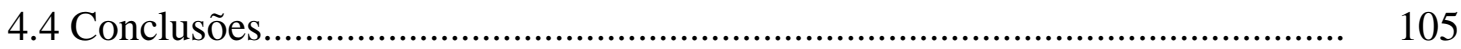

5 HERANÇA DA REAÇÃO DE Capsicum chinense AO OÍDIO........................... 106

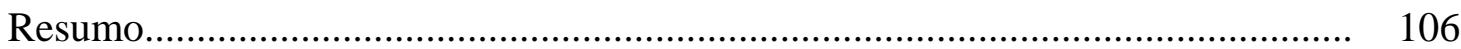

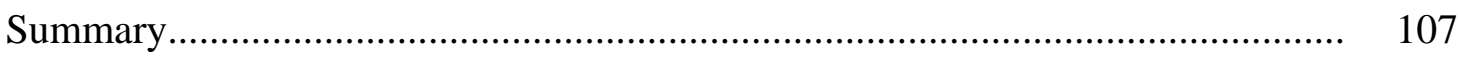

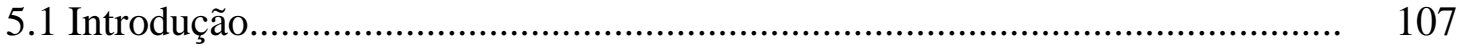

5.2 Material e Métodos.................................................................................. 110

5.3 Resultados e Discussão........................................................................... 120

5.4 Conclusões........................................................................................... 138

6 CONCLUSÕES GERAIS.......................................................................... 139

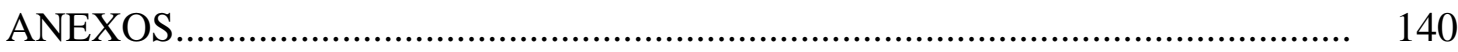

REFERÊNCIAS BIBLIOGRÁFICAS............................................................... 147 


\title{
HERANÇA DA REAÇÃO DE Capsicum spp AO OÍDIO (Leveillula taurica (LEV.) ARN.)
}

\author{
Autora: SALLY FERREIRA BLAT \\ Orientador: Prof. Dr. CYRO PAULINO DA COSTA
}

\section{RESUMO}

O oídio do pimentão e pimenteiras, causado pelo fungo Leveillula taurica, tem sido considerado atualmente a doença mais séria do cultivo protegido, causando perdas de até $75 \%$. O uso de fungicidas é ineficaz sendo a melhor maneira de controle através da resistência genética. As fontes de resistência ao oídio encontradas em Capsicum annuum L., não tem sido satisfatórias por apresentarem resistência parcial e as melhores fontes ocorrem nas espécies C. baccatum e C. chinense. Existem poucos estudos sobre a herança da resistência nessas espécies. O objetivo deste trabalho foi de triar os acessos da coleção de Capsicum da ESALQ/USP, identificando possíveis fontes de resistência nas espécies $C$. annuum, $C$. baccatum e $C$. chinense e obter informações sobre a herança da reação de pimentão e pimentas ao oídio. Para isso 156 acessos de Capsicum foram triados e posteriormente cruzamentos entre progenitores resistentes versus suscetíveis e resistentes versus resistentes foram obtidos. As gerações $F_{2}$ e alguns retrocruzamentos foram obtidos. As avaliações das reações ao oídio foram feitas na fase de frutificação, através de uma escala de notas de acordo com a severidade da doença de 1 (resistente) a 5 (altamente suscetível). Foram estimados: o número de locos segregantes, os coeficientes de herdabilidade, os progressos esperados na seleção e o tipo de ação gênica envolvida. Foram avaliadas também as reações dos híbridos entre progenitores resistentes. Dentre os materiais triados em C. annuum apenas 5\% foram considerados 
resistentes, em C. baccatum 84\% e em C. chinense 85\%. A herança da resistência aooídio em Capsicum mostrou ser poligênica. As herdabilidades e ganhos de seleção estimados foram altos, indicando boas perspectivas de progresso seletivo. Os progenitores resistentes em Capsicum annuum possuem diferentes mecanismos genéticos e expressões de resistência. Enquanto em C. baccatum e C. chinense os mecanismos de resistência mostraram ser os mesmos, havendo alelismo entre as fontes. A fonte de resistência do pimentão HV-12 foi a melhor para o uso no melhoramento. 


\title{
INHERITANCE REACTION IN Capsicum spp. TO POWDERY MILDEW (Leveillula taurica (LEV.) ARN.)
}

\author{
Author: SALLY FERREIRA BLAT \\ Adviser: Prof. Dr. CYRO PAULINO DA COSTA
}

\section{SUMMARY}

Powdery mildew caused by the fungus Leveillula taurica, is considered the most serious greenhouse sweet pepper disease, causing losses up to $75 \%$. Its control by fungicide is ineffective, and the best way to control would be by genetic resistance. Powdery mildew resistance sources identified in Capsicum annuum L. have been unsatisfactory because they have partial resistance. The best resistant sources seem to be found in the species $C$. baccatum and C. chinense. However, the resistance inheritance has not been studied in these hot pepper species, except for $C$. annuum, with few published pappers. The present study aimed to screen the Capsicum ESALQ/USP collection accesses, to identify potential resistance sources in C. annuum, C. baccatum and $C$. chinense and elucidate the reaction inheritance to powdery mildew in sweet pepper and hot pepper. A total 156 Capsicum access were tested. Crosses among resistant and susceptible progenitors and among resistant ones were carried out. $F_{2}$ and backcrosses generations were obtained. Reactions evaluations to powdery mildew were carried out during the fruit production using rating system based on score disease severity using scale varying from 1 (resistant) to 5 (highly susceptible). Estimation of segregating loci number, heritability and expected selection gains was made, to investigate the gene action and to evaluate the reaction to powdery mildew from resistant versus resistant single hybrids. Only 5\% of the C. annuum accesses evaluated 
were considered to be resistant, in contrast with $84 \%$ and $85 \%$ obtained for C. baccatum and $C$. chinense, respectively. Resistance inheritance to powdery mildew in Capsicum spp. was found to be polygenic. In view of the high heritability and selection gains estimates, good selection progresses are expected. The genetic systems controlling resistance in the Capsicum annuum progenitors have different genetic mechanisms and expressions of resistance, while in C. baccatum and C. chinense showed to be the same in each ones with allelism between the sources. The sweet pepper HV-12 was the best source to use in breeding. 


\section{INTRODUÇÃO}

O pimentão pertence à família Solanaceae, gênero Capsicum e espécie Capsicum annuum L. O gênero é originário da América Tropical e bem distribuído por toda América latina. A produção mundial de pimentas e pimentões ocupa cerca de 1,3 milhão de hectares e a exportação de produtos derivados de pimentas e pimentões nos últimos anos trouxe divisas para o Brasil de US\$ 735,8 mil. Apenas a comercialização de sementes de Capsicum no país envolve recursos da ordem de 1,5 milhão de dólares (Bertão, 1993, CNPH, 2001). No Brasil a produção concentra-se principalmente nos estados de São Paulo e Minas Gerais, onde foram cultivados cerca de 5000 ha em 1998, atingindo uma produção de 120 mil toneladas (Souza, 2000).

O cultivo de pimentão em estufa e o uso híbridos têm sido os fatores responsáveis pelo incremento na produtividade e qualidade. Junto a essa demanda crescente pela plasticultura, surgiu uma nova doença a partir de 1994, a qual vem preocupando os produtores pelos seus enormes danos causados e seu difícil controle; o oídio, causado pelo fungo Leveillula taurica. O uso de fungicidas sistêmicos e com especificidade para o controle não tem funcionado. Além do mais o uso de fungicidas sistêmicos de maneira indiscriminada poderá induzir e promover o surgimento de raças resistentes do patógeno ao fungicida (Palti, 1988, Bergamin Filho et al., 1995).

A melhor maneira de controlar $L$. taurica é através de variedades com resistência genética. Existem relatos na literatura com referência a resistência de pimentão e pimentas ao patógeno (Shifriss et al., 1992, Daubeze, et al., 1995). Tudo parece indicar que as melhores fontes de resistência foram identificadas nas espécies de Capsicum chinense e C. baccatum. A resistência ao oídio encontrada em Capsicum annuum L., não tem sido satisfatória por apresentar resistência parcial (Shifriss et al., 1992). 
Postulou-se que a coleção de germoplasma de Capsicum da ESALQ/USP constituída de mais de 200 acessos poderia ser triada para identificação de fontes de resistência à Leveillula taurica. O objetivo dessa pesquisa foi: identificar fontes de resistência nas diferentes espécies de Capsicum e obter informações sobre a herança da resistência, podendo através dessas contribuir para programas de melhoramento genético de pimentão e pimentas resistentes ao oídio. 


\section{REVISÃO DE LITERATURA}

\subsection{O gênero Capsicum}

Todas as formas de pimentão e pimentas utilizadas pelo homem pertencem ao gênero Capsicum. O nome científico do gênero deriva segundo alguns autores de Kapso (picar) e outros Kapsakes (cápsula). Inclui-se na família das solananceas.

Existem várias hipóteses sobre o local e modo de evolução das espécies de Capsicum. A mais aceita é a de Mc Leod et al. (1982) que sugeriram que uma porção importante do gênero se originou em uma área nuclear na Bolívia Sul-Central com subseqüentes migrações aos Andes e terras baixas da Amazônia acompanhada pela radiação e especialização. Segundo Costa (1977), os pimentões e as pimentas têm sua origem na América tropical, na mesma região do milho, tendo pelo menos um centro de origem na América do Sul, outro no México e distribuição por toda América Latina.

No gênero Capsicum o número de espécies varia entre os autores, sendo cerca de 25 espécies. Porém todos eles concordam na existência de apenas cinco espécies domesticadas: C. annuum L. var annuum (pimentão), C. baccatum L. var. pendulum (Wild.) (pimenta dedo-de moça), C. chinense Jacq (pimenta de cheiro), C. frutescens L. (pimenta malagueta) e C. pubescens Ruiz \& Pavon. As demais espécies são semidomesticadas e silvestres. C. annuum apresenta flores solitárias, corola branca sem manchas difusas na base das pétalas, é a espécie mais domesticada, cultivada e que apresenta maior variabilidade, sendo representada por pimentões e algumas pimentas. $C$. chinense apresenta duas ou mais flores em cada nó, corola branca-esverdeada sem manchas difusas na base das pétalas, possui uma constituição marcante na base do cálice em formato de sino. C. baccatum apresenta flores solitárias, corola branca-esverdeada, com manchas amarelas difusas na base das pétalas. $C$. frutescens é semelhante a $C$. 
annuum, com a diferença que produz corola branca-esverdeada e frutos de formato diferente e de sabor picante, e C. pubescens que apresenta flores solitárias, corola púrpura sem manchas difusas na base das pétalas e sementes de coloração escura. Essas últimas quatro espécies se destacam pela por serem boas fontes de resistência a pragas e doenças (Reifschneider et al., 1998).

Uma das maiores características desse gênero é a sua alta variabilidade de tipos de frutos, cores, formas, tamanhos e intensidade de sabor picante (Capsaicina).

\subsection{Importância e ocorrência do oídio (Leveillula taurica)}

Os agentes causais de oídios são fungos parasitas biotróficos obrigatórios, que dependem do hospedeiro vivo para seu crescimento e reprodução, e não possuem fase saprófita. Em razão de ser um patógeno obrigatório, o mesmo deve se adaptar constantemente ao hospedeiro, implicando uma alta especificidade na relação patógenohospedeiro, caracterizando um relacionamento altamente evoluído e complexo (Stadnik \& Rivera, 2001).

O oídio da pimenta e pimentão tem uma ampla gama de distribuição. Ocorre na região Mediterrânea e Asiática (Palti, 1988; Sulinam et al. 1999), mas o pimentão é o único hospedeiro entre as solanáceas em que o oídio tem sido registrado nos países na África (região do Saara), bem como em muitas regiões da América do Sul e Central, e da Austrália.

O primeiro relato de ocorrência de Leveillula taurica em pimentão no Brasil foi na região do DF (Boiteux ${ }^{1}$ et al., 1994 citados por Souza, 2000). Alguns autores citam o gênero Oidiopsis, entretanto outros se referem ao fungo como provável anamorfo de $L$. taurica (Braun², 1987; citados por Souza, 2000). Sinagaglia et al. (1995), encontrou $L$ taurica, na sua forma anamórfica de Oidiopsis taurica causando sérios prejuízos em plantio de pimentão no sistema de plasticultura na região de Itupeva-SP.

\footnotetext{
${ }^{1}$ BOITEUX, L.S.; SANTOS, J.R.M.;LOPES, C.A. First record of powdery of sweet pepper Capsicum annuum incited by Leveillula taurica in Brazil. Fitopatologia Brasileira, 19 (supl.), p. 304, 1994.

${ }^{2}$ BRAUN, U. A monograph of the Erysiphales (powdery mildew). Nova Hedwigia (suppl), n. 89. Sluttgart, Germany; J. Craner, 1987. 700p.
} 
Plantios sucessivos de pimentão e tomate nas regiões Sudeste, Centro-oeste e Nordeste do Brasil resultaram no estabelecimento desta forma de oídio, que atualmente é responsável por elevados danos econômicos à cultura.

Atualmente o oídio ocorre nas principais áreas produtoras da América, desde cultivos em campo em regiões tropicais até em cultivos protegidos em regiões de clima temperado (Damicone \& Sutherland, 1999). Estes autores citam que o aumento do cultivo de pimentão em hidroponia poderia estar favorecendo a ocorrência do Leveillula.

L. taurica é um patógeno que pode também infectar vários grupos de plantas como o tomate (Correl et al., 1987) e outras solanaceas (Palti, 1988), alcachofra, pepino (Molot \& Lecoq, 1986), quiabo, algodão, fava (Nour, 1958), alho porro, cebola e muitas outras (Palti, 1988, Daubeze et al., 1995).

Desconhece-se a existência de raças de O. taurica (Mulge \& Anand, 1997), possivelmente pelo fato da resistência genética ser rara. Quatro hospedeiros específicos de isolados de L. taurica foram estudados por Molot et a.l. (1990), observou-se que quatro isolados de diferentes espécies hospedeiras foram capazes de infectar os quatro hospedeiros.

O oídio do tomate causado por L. taurica foi encontrado em culturas de tomate, pimentão, algodão, alcachofra e cebola da Califórnia. As características morfológicas de L. taurica foram similares em todos os hospedeiros. Todos os isolados testados, exceto um para a alcachofra, foram capazes de infectar o tomateiro e aparentemente apresentaram a mesma raça fisiológica do patógeno (Correl et al., 1987).

\subsection{Sintomatologia e caracterização}

Os agentes causais de oídios são fungos da classe dos Ascomicetos, família Erysiphaceae. Oidiopsis taurica (E. S. Salmon) é o estádio, assexual, anamorfico e conidial encontrado nas espécies de Leveillula. O fungo produz hifas claras e septadas, que formam um micélio branco ou cinza claro. As hifas dão origem a conidióforos curtos, eretos e não ramificados, a partir dos quais se desenvolvem os conídios, arranjados em cadeia. Os conídios são hialinos, unicelulares, de forma ligeiramente retangular a ovalada ou oblonga. As hifas formam também haustórios, que são estruturas 
especializadas na retirada de nutrientes diretamente das células do hospedeiro. Estas estruturas, provenientes do intumescimento das extremidades das hifas que penetram no interior das células, permitem que o fungo exerça uma forma evoluída de parasitismo, proporcionando uma longa convivência entre patógeno e hospedeiro (Bergamin Filho et al., 1995).

O estadio sexual, teleomorfo ou cleistotecial é denominado Leveillula (Lév.) G. Arnaud. Neste estadio, o micélio forma corpos de frutificação do tipo cleistotécio, claros no início, posteriormente escuros, de modo a tornarem-se bem visíveis, em contraste com o micélio branco. Segundo Braun (1980) o diâmetro do ascoma de L. taurica varia entre 120 e $280 \mu \mathrm{m}$, possui coloração marrom escura com apêndices bem desenvolvidos e numerosos, com mais de vinte ascas em cada cleistotécio de forma cilíndrica a clavada, variando de $60-120 \mu \mathrm{m} \times 25-45 \mu \mathrm{m}$. As ascas frequentemente possuem dois ascósporos. Esta fase perfeita nunca foi encontrada em pimentão (Palti, 1988).

O oídio penetra pelos estômatos e a característica que diferencia dos demais oídios é o fato deste desenvolver micélio interno causando necrose de algumas células, principalmente localizada no parênquima lacunoso. Produzem dois tipos de conídios (primário de formato laceolado e secundário de formato cilíndrico) que ao germinarem produzem tubos germinativos bastante prolongados, que no momento da infecção desenvolvem lobos de adesão na superfície epidérmica do tecido. Após a colonização do tecido de plantas suscetíveis ocorre a emergência de uma grande quantidade de conidióforos através da abertura ostiolar. Esta característica da doença interfere nas trocas gasosas das plantas afetadas (Café Filho et al., 2001)

Em pimentão, antes do surgimento dos sintomas, verificam-se inicialmente sinais do patógeno na região abaxial. Com o desenvolvimento da infecção, as colônias pulverulentas brancas resultantes da massa conidial progridem e coalescem. Concomitantemente, no ponto da face adaxial foliar correspondente surgem manchas cloróticas. Mais tarde, o pecíolo torna-se amarelecido, formando uma zona de abscisão próxima à interseção com o caule, provocando defoliação (Palti, 1988; Daubeze et al., 1995). Deste modo a defoliação é um dos mais marcantes e prejudiciais sintomas de oídio do pimentão. 
O fenômeno de abscisão foliar pode ser atribuído a ação de hormônios produzidos pelo patógeno (Wiese \& Devay, 1970), hormônios produzidos pelas plantas hospedeiras após infecção pelo patógeno (Williamson, 1950), ou inibidores da ação de enzimas das plantas hospedeiras (Sequeira \& Steeves, 1954). No patossistema pimentão versus $O$. taurica, a abscisão foliar pode ainda ser influenciada por manganês e efeito hormonal da auxina (Reuveni et al., 1976), ou por elevada atividade da isoenzimas de peroxidase no pedúnculo foliar (Reuveni \& Pearl, 1979).

Os primeiros sintomas e sinais são sempre encontrados em plantas mais adultas e folhas mais velhas, que são mais suscetíveis ao patógeno. Plantas jovens são imunes, independentemente da variedade (Souza \& Café Filho, 2000).

Lima (2002), verificou uma correlação negativa, mas altamente significativa entre o número de dias do transplante ao florescimento com os graus de resistência. Existem indícios que a medida que o genótipo floresce mais precocemente ocorre maior predisposição para suscetibilidade. Assim a precocidade no florescimento e frutificação poderá ser considerada na expressão da doença.

Damicone \& Sutherland (1999), em pimentão cultivado no sistema de hidroponia em Oklahoma, tiveram níveis de defoliações de 50 a 75\% nos cultivares Valência, Lavender Islander, Sweet Chocolate, Aladdin, Purple Beauty, Golden Summer, Chocolate Beauty, Early Sunsation, Fat N’Sassy, Lilac, Sweet Rainbow Mix e Ivory. Conseqüentemente os frutos da plantas infectadas foram pequenos e sem padrão.

Velasquez-Valle \& Valle-Garcia (1999) observaram que a incidência de oídio nos campos de pimentão em Zacatecas, México, foi alta onde havia adensamento de plantas e alta umidade. Esta incidência variou de 35 à $80 \%$ na cultivar Ancho e de 0 à 55\% na pimenta Mirasol. Nos países do mediterrâneo, Ásia Central e oeste e regiões subtropicais, as perdas de produção causadas por Leveillula taurica em pimentão em campo chegaram a 30-40\% (Palti, $1971^{3}$, citado por Daubeze, 1995).

Cerkauskas et al. (1999), em Ontário, Canadá relataram a incidência de oídio do pimentão em casa de vegetação nas cvs. Oberon e Triplo 4, e na cv. Fireflame de

\footnotetext{
${ }^{3}$ PALTI, J. Biological characteristics, distribuition and control of Leveillula taurica (Lev.) Arn.
}

Phytopathol. Medit., v. 10, p. 139-153, 1971. 
pimenta. O nível de perdas foi de 10 à 15\%. As lesões apareceram das folhas mais velhas para as mais novas em plantas de pimentão, inicialmente como manchas brancas na fase inferior das folhas. Outra ocorrência de Leveillula taurica no Canadá, foi relatada também por Cerkauskas (2003) em British Columbia, em um cultivo orgânico em casa de vegetação. Além de perdas foliares da ordem de até $80 \%$, prejuízos na produção de frutos de 2 a 4 quilos por metro quadrado foram notados.

Quanto as condições de umidade e temperatura ideais para o desenvolvimento da epidemia do oídio do pimentão, existem vários relatos de autores.

Segundo Smith et al. (1999), L. taurica (= Oidiopsis taurica) é o único entre os oídios que tem hábito de crescimento interno. As hifas do fungo crescem dentro do tecido do hospedeiro, preferencialmente mais do que na superfície do tecido das folhas, fato comum aos oídios que infectam a maioria dos hospedeiros. Os esporos do oídio do pimentão, diferente da maioria dos tipos dos oídios contém água suficiente para seu crescimento e podem germinar em condições de umidade relativamente baixa. A germinação pode ocorrer na faixa de 40 a 90\%, com o ótimo a 90\%. Essa água adicional que os esporos contém, torna-os suscetíveis a romper-se na presença de água livre, como em chuvas e irrigação por aspersão.

Segundo Molot et al. (1990), contrariamente às espécies de Erysiphe e Sphaerotheca, L. taurica necessita de alta umidade relativa para a germinação e crescimento do tubo germinativo. Reuveni \& Rotem (1973) estudando os efeitos das combinações de temperaturas e umidade relativa no desenvolvimento da doença em pimentão e tomate verificou que em pimentão a epidemia foi favorecida pela alta umidade relativa (85-95\%), enquanto o oídio do tomateiro se desenvolveu mais em baixa umidade relativa (50\%).

Já segundo Shifriss et al. (1992) em cultivo protegido, a ausência de precipitação, baixa umidade e a temperatura em torno de $32^{\circ} \mathrm{C}$ favoreceram o estabelecimento do patógeno. Do mesmo modo, no cultivo de campo, a doença foi favorecida em época seca (Chen ${ }^{4}$ et al., 1996, citados por Souza, 2000).

\footnotetext{
${ }^{4}$ CHEN, Y.K.; CHEIN, C.C.; CHEN, L.C. Occurence of powdery mildew on golden callo lily in Taiwan. Ann. Phytopathol. Soc. Jap. , v. 62, p.580-83, 1996.
} 
Com relação a temperatura Reuveni et al. (1974) observaram que a maior taxa de defoliação em pimentão ocorreu na temperatura de $20^{\circ} \mathrm{C}$, sendo esta a temperatura ótima para o desenvolvimento da doença e que além da abscisão em folhas com alta taxa de esporulação, o patógeno pode também induzir um desbalanço hormonal, possivelmente relacionado com a síntese de etileno, ocasionando a queda de folhas sem sintomas aparentes.

\subsection{Herança e ocorrência de resistência a Leveillula taurica em Capsicum}

A resistência a Oídios pode ser vista como a capacidade do hospedeiro em evitar ou atrasar a penetração e/ou o subseqüente desenvolvimento do patógeno. Resumidamente, os hospedeiros podem reagir ao patógeno pela formação de papilas, reações de hipersensibilidade, síntese de compostos antimicrobianos e/ou por alterações metabólicas em seus tecidos. A reação de resistência ou suscetibilidade do hospedeiro a determinado patógeno é característica geneticamente herdada. Análises genéticas da resistência do hospedeiro e avirulência do patógeno confirmam para interações entre oídios e seus hospedeiros, a teoria gene-a-gene (Flor 1942). Segundo esta teoria, para cada gene de resistência (R) no hospedeiro existe um gene de avirulência no patógeno (AVR). A teoria gene-a-gene é comum em interações planta-patógeno e reflete a capacidade das plantas em reconhecerem o patógeno invasor (Stadnik \& Rivera, 2001).

Variações na resistência a um patógeno podem ser expressas contínua ou descontinuamente em uma população segregante, dependendo do número de genes de resistência que estão envolvidos. Se a variação é contínua, ocorre um gradiente entre suscetibilidade e resistência e muitos genes de resistência estão envolvidos, sendo a resistência poligênica. Caso a variação seja descontínua, os indivíduos de uma população segregante enquadram-se em classes bem definidas de resistência ou suscetibilidade, e admite-se que a resistência é controlada por um (monogênica) ou poucos genes (oligogênica) (Mather \& Jinks, 1984).

Outro fator de fundamental importância na caracterização de grupos de resistência é o período de latência, pois corresponde ao tempo dispendido pelo patógeno nos processos de infecção e colonização. O processo do oídio do pimentão obedece as 
características do processo temporal típicas de doenças policíclicas sensu Van Der Plank (1963). Neste tipo de doenças, o período de latência é uma das variáveis que mais influencia a velocidade de crescimento da epidemia; quanto maior o tempo decorrido entre a inoculação e a reprodução, menor o número de gerações produzidas por ciclo do hospedeiro reduzindo a taxa de infecção (Amorim, 1995).

Chander (1994), verificou através de seus estudos que a atividade da fenilalanina amônia-lise (PAL) e níveis de fenóis totais e flavonoides, bem como a atividade da peroxidade, estavam presentes em maiores proporções na cv. IHR 517 de Capsicum que mostrou-se resistente a $L$. taurica do que na cv suscetível IHR 423.

As melhores fontes de resistência no gênero Capsicum foram identificadas nas espécies de Capsicum chinense e C. baccatum. O tipo de resistência encontrada em Capsicum annuum L., não tem sido satisfatória por apresentar resistência parcial (Shifriss et al., 1992). Ullasa et al. (1981) testaram a resistência de 300 acessos e variedades de Capsicum, à Leveillula taurica na Índia. Eles encontraram três espécies sendo resistentes, C. microcarpum, C. pendulum e C. pubescens e treze linhagens não melhoradas de Capsicum annuum sendo moderadamente resistentes.

Blazquez (1976), testou pimentas do tipo pungente e não pungente, das quais quatro do tipo não pungente foram completamente resistentes e somente Jalapeño do tipo pungente, foi suscetível. Bidari et al. (1985), testaram 60 variedades, somente Puri Orange 2, mostrou-se tolerante.

Blancard et al. (1995), avaliando a espécie Capsicum annuum, encontrou uma fonte de resistência no acesso PM687, e verificou que esta resistência pode estar associada à queda das primeiras flores.

Bechir (1993), testou 13 acessos de pimentão para resistência a Leveillula taurica sob condições naturais de infecção em casa de vegetação na Tunísia. Todas as folhas de cada planta foram marcadas visualmente seguindo a escala de notas de Molot e Lecoq, 1986, dando uma nota de 0 à 5. O haplodiplóide HV 106 foi suscetível como as variedades Beldi, Semmene e Nabeul 2. Os acessos PM681 e PM 687 foram parcialmente resistentes, enquanto que as linhagens PM803, HV12 e HV13 foram muito resistentes. O crescimento do micélio foi rapidamente restringido em PM803, havendo 
coalescência de lesões necróticas que induziram uma queda prematura de folhas como se fosse uma reação de hipersensibilidade. Contudo, na área foliar de HV12 e HV13 ocorreram somente algumas manchas cloróticas pequenas.

Sulinam et al. (1999), objetivando testar a agressividade de muitos isolados de $L$. taurica em diferentes locais, testaram duas variedades de pimentão "Vania e PM687". Plantas com cinco semanas de idade foram inoculadas com suspensão de $10^{5}$ conídios/ml. A reação varietal foi avaliada com base na escala da severidade da doença com notas de 0 à 5 . A avaliação foi feita em intervalos de 7 dias após a inoculação até 49 dias. Todos os isolados de L. taurica foram patogênicos considerando o padrão suscetível. As menores notas somente foram observadas na linhagem parcialmente resistente, PM687 para quatro dos seis isolados (P45, P46,P31, P49), e nenhum sintoma foi observado para os outros dois isolados (P32 e P38).

Ahmed et al. (1998) avaliaram um total de 36 linhagens de pimentão para resistência a Leveillula taurica. A avaliação foi realizada sob condições de infecção natural em dois locais (Nesheshiba e Abu Haraz). Uma escala de notas de 1 (extremamente suscetível) a 9 (altamente resistente) foi usada. As avaliações das reações ocorreram quando as plantas tinham 3 a 4 meses de idade na fase de frutificação. A incidência da doença foi similar nos dois locais, pois em ambos locais as linhagens suscetíveis foram altamente infectadas. Contudo a média da primeira avaliação foi maior que da segunda avaliação, sugerindo que a reação de resistência em estádios mais avançados próximos a maturidade pode ser alterada. Deste modo, a seleção para resistência deve ser realizada na fase final de frutificação do pimentão, para uma melhor identificação da reação do pimentão.

Zewdie (1994), avaliaram 44 linhagens para incidência de oídio (0-100\%) em Nazareth, Ethiopia. A incidência foi severa na maioria das linhagens. O registro da doença apareceu nas linhagens PBC376, PBC210, PBC233, PBC266, PBC270, PBC374 e PBC378. As folhas colonizadas pelo patógeno caíram após alguns dias. A linhagem PBC376 mostrou maior tolerância na produção do que a padrão suscetível. Os acessos PBC151 e PBC171, pertencentes à espécie Capsicum baccatum e C. chinense, mostraram alto nível de resistência em condições de campo. 
Muneem et al. (1995), avaliaram 150 acessos do Serviço de Introdução de Plantas do USDA, para reação à mancha foliar, oídio e podridão do fruto numa escala de 0-9. Os padrões de suscetibilidade para mancha foliar, oídio e podridão do fruto foram respectivamente: IC92298, IC92299 e P-2072. Os acessos IC99910, IC99912, IC92150, P-1718, P-1939, N-1015, EC362901, EC362910, EC362913, EC362925, EC362934, EC362935 e EEC3637 foram resistentes às manchas foliares, oídio e podridão de fruto.

O oídio em tomate pode ser causado por Leveillula taurica. Uma resistência monogênica dominante devido ao gene Lv foi identificada na Bulgária a partir de um cruzamento entre $L$. esculentum e $L$. chilense. Mais tarde a resistência foi também demonstrada em uma linhagem na Costa Rica, mas ainda é desconhecido o alelismo com o gene Lv. O gene Lv até o momento não tem sido incorporado em variedades comerciais (Cuartero, 1999).

Quanto a genética da herança Daubeze et al. (1989) concluíram em seus estudos que pelo menos três genes estariam relacionados no controle da resistência. Shifriss et al. (1992) avaliaram a linhagem HV12, seu cruzamento com o parental 1646 suscetível, híbridos $F_{1}$, geração $F_{2}$ e retrocruzamentos e com base nos resultados obtidos concluíram também que a resistência seria controlada por três pares de genes recessivos independentes. Já Daubeze et al. (1995) sugeriram que três fatores estariam envolvidos na fase inicial do ciclo de resistência ao oídio, caracterizando uma ação gênica parcialmente dominante para a suscetibilidade e cinco fatores envolvendo epistasia governariam esta resistência na fase final da epidemia, indicando que a resistência é controlada por vários genes. Mulge \& Anand (1997) testaram a resistência de oídio em pimentão usando linhagens e uma variedade comercial como testemunha. Observaramse os sintomas do oídio nos parentais e híbridos confirmando uma natureza dominante da resistência, a qual pode ser explorada em combinações heteróticas.

Murthy \& Deshpande (1997), utilizando-se de fontes indianas na elucidação da herança da resistência ao oídio, relataram que esta seria de natureza dominante e controlada poligenicamente. Efeitos gênicos aditivos $\mathrm{x}$ aditivos foram verificados em todos os cruzamentos. 
Souza (2000), avaliou a reação a L.. taurica em acessos do Banco de Germoplasma de Capsicum da Embrapa Hortaliças, além de híbridos e variedades comerciais. Identificaram-se oito acessos imunes: HV12, 4638 e pimentas como ABE (CNPH 36), Kurimoto (CNPH 38), Nélio redonda (CNPH 50), Nélio Fina 2 (CNPH 52), Escabeche (CNPH 279) e Malagueta (CNPH 288). Um fato interessante observado foi que na espécie C. annuum $L$. $70 \%$ dos materiais foi moderadamente suscetível a $L$. taurica. Nas espécies $C$. baccatum, $C$. frutescens e $C$. chinense a situação se inverteu, ocorrendo menor número de acessos suscetíveis e muitos resistentes.

Lima (2002), com o objetivo de identificar fontes de resistência em Capsicum ao oídio, em telado e casa de vegetação, testaram 104 genótipos (83 de C. annuum, 11 de $C$. chinense, seis de $C$. baccatum e quatro de $C$. frutescens) inoculando artificialmente ( $10^{4}$ conídios/ml) em telado e naturalmente em casa de vegetação. Cerca de $68 \%$ dos genótipos avaliados em telado foram considerados altamente suscetíveis (AS), 8,7\% moderadamente suscetíveis (MS), 7,8\% moderadamente resistentes (MR), 11,5\% resistentes (R) e 4\% foram altamente resistentes (AR). Dos genótipos avaliados em casa de vegetação, 56\% foram AS; 16\% MS, 11\% MR, 10\% R e 8\% foram AR. Observou também que os genótipos resistentes apresentaram período de latência superior aos genótipos suscetíveis e que o genótipos Magali (AS), apresentou média de freqüência estomatal e número de estômatos significativamente superior em relação a média do genótipo HV-12 (AR), em ambas as faces foliares. 


\title{
3 HERANÇA DA REAÇÃO DE Capsicum annuum AO OÍDIO
}

\author{
Autora: SALLY FERREIRA BLAT \\ Orientador: Prof. Dr. CYRO PAULINO DA COSTA
}

\section{Resumo}

O uso de fungicidas no controle do oídio do pimentão tem se mostrado ineficaz. Tudo parece indicar que a resistência genética será a melhor forma de controle dessa doença, porém as fontes de resistência identificadas em Capsicum annuum L. são mínimas e não tem sido satisfatórias por apresentarem resistência parcial. Atualmente todos os híbridos disponíveis no mercado mundial de sementes de pimentão são altamente suscetíveis ao oídio e a herança da reação tem sido pouco estudada. Com isso o objetivo deste trabalho foi triar os acessos da coleção de C. annuum L. da ESALQ/USP, identificando possíveis fontes de resistência nesta espécie e obter informações sobre a herança da reação de pimentão e pimentas ao oídio. Foram testados 99 acessos de C. annuum para identificar fontes de resistência e suscetibilidade. A partir de três acessos resistentes, foram feitos cruzamentos entre si e também com linhagens altamente suscetíveis ao oídio, resistentes ao PVY, TSWV e TMV. Foram obtidas as gerações $F_{1}, F_{2}$ e retrocruzamentos. As avaliações das reações ao oídio foram feitas na fase de frutificação, através de uma escala de notas de acordo com a severidade da doença de 1 (resistente) a 5 (altamente suscetível). Foram estimados: número de locos segregantes, coeficientes de herdabilidade, tipo de ação gênica envolvida nos cruzamentos, progressos esperados e observados na seleção e avaliadas as reações dos híbridos entre progenitores resistentes. Entre os acessos triados apenas 5\% foram considerados resistentes; destacando-se as pimentas Chilli e \#124, além do pimentão 
HV-12. A herança da reação ao oídio no cruzamento HV-12 x 609 mostrou ser de natureza aditiva e para os demais cruzamentos além da ação aditiva, detectaram-se efeitos dominantes e epistáticos. A herança foi caracterizada como recessiva e governada por pelo menos quatro pares de genes. As herdabilidades e ganhos de seleção estimados foram altos e os progressos observados com a seleção na geração $F_{3}$ confirmaram esses resultados variando de $34,7 \%$ a 45,0\%. O mecanismo de resistência dos progenitores resistentes \#124, Chilli e HV-12 têm diferenças de expressão e possivelmente de natureza genética.

\section{INHERITANCE REACTION IN Capsicum annuUm TO POWDERY MILDEW}

Author: SALLY FERREIRA BLAT

Adviser: Prof. Dr. CYRO PAULINO DA COSTA

\section{Summary}

The use of fungicides to control powdery mildew in sweet pepper has been ineffective. Genetic resistance is the best way to control this disease. However, resistance sources identified in Capsicum annuum L. are rare and most of them are showed partial resistance. Up to now, all sweet pepper hybrids available in worldwide are highly susceptible to powdery mildew. There have been few studies about resistance reaction inheritance. Therefore, this study aimed to screen the C. annuum L. ESALQ/USP collection to identify potential resistance source and to elucidate inheritance sweet and hot pepper reaction to powdery mildew. Ninety-nine access of $C$. annuum L. were evaluated and screened. Crossings were carried out among three identified resistant accesses, and with lines highly susceptible to powdery mildew, but resistant to viruses. $F_{1}, F_{2}$ and backcross generations were obtained. Reaction evaluations of powdery mildew were carried out during the fruit production by using a rating system based on score disease severity using scales varying from 1 (resistant) to 5 (highly susceptible). Estimation of segregating loci number, heritability and expected and actual selection gains was made, to investigate the gene action involved in the 
crosses and to evaluate the reaction to powdery mildew of hybrids obtained from crossing between resistant progenitors. Considering the evaluated materials, only 5\% were considered resistant, being Chilli and \#124 hot peppers and HV-12 sweet pepper the best ones. It could be concluded that the powdery mildew reaction based on HV-12 x 609 crossing is of additive nature, while the others crossings showed dominant and epistatic effects, besides the additive action. Resistance was characterized as being recessive and due to at least four pairs of genes. The heritability and selection gains estimates were high, and $\mathrm{F}_{3}$ generation selection progresses observed range, from $34.7 \%$ to $45.0 \%$, supporting such results. The resistance mechanisms of \#124, Chilli and HV-12 showed differences in their expression.

\subsection{Introdução}

O pimentão foi desenvolvido na Europa após a descoberta da América, através da introdução de inúmeras amostras de germoplasma de pimenta. Deve ter sido selecionado pela ausência de pungência, frutos maiores e maior capacidade de autofecundação. Os

pimentões que foram introduzidos no Brasil vieram da Espanha e constituíram o tipo Casca Dura (Costa, 1977). Foi domesticado na América Central, provavelmente no México e se expandiu rapidamente pelo mundo, sendo difícil encontrar algum lugar onde não se utiliza algum de seus produtos (Nuez, 1996, Bertão, 1993). É uma hortaliça rica em vitamina $\mathrm{C}, \mathrm{A}, \mathrm{B} 1$ e $\mathrm{B} 2$ e minerais como cálcio, ferro e fósforo.

Pertencente ao gênero Capsicum e espécie C. annuum L. está entre as 10 hortaliças mais consumidas no mercado brasileiro e mundial. Estima-se que dos 13 mil hectares de área cultivada no Brasil, 1000ha são destinados ao cultivo protegido. O mercado de sementes de pimentão no Brasil é estimado em US\$ 3 milhões/ano, dos quais US\$ 600 a 900 mil estão relacionados ao segmento de pimentão de estufa. Na Europa (Espanha e Itália) e no nordeste dos Estados Unidos e Canadá onde predomina o cultivo protegido de pimentão, o mercado de sementes é estimado respectivamente em US\$ 38 milhões e US\$ 4 milhões. Nos últimos anos a exportação de produtos derivados de pimentas e pimentões gerou divisas para o Brasil da ordem de US\$ 735,8 mil (CNPH, 2001). 
A produtividade média brasileira no período de 1996 a 2000 teve um aumento médio de $300 \%$, passando de 10,4 para 32,6 toneladas por hectare. A distribuição do plantio de pimentão concentra-se na região sudeste, sendo que os estados de São Paulo e Minas Gerais, representam 43\% do plantio nacional, sendo seguidos pela região nordeste (31\%), sul (20\%), centro-oeste (5\%) e norte (1\%). (CNPH, 2001). Na região sudeste, São Paulo destaca-se como o maior produtor com 8.291 hectares, produzindo 70 mil toneladas e gerando 4.543 empregos.

Existem inúmeras doenças que limitam a produção de pimentão. Atualmente o Oídio, causado por Leveillula taurica tem sido a doença mais destrutiva e preocupante para os produtores dessa cultura em estufa, pois além de causar enormes perdas, seu controle com uso de fungicidas não tem sido eficaz. $\mathrm{O}$ uso de controles alternativos como leite de vaca, fosfato monopotássico, tem sido testado, porém com efeitos limitados. A melhor maneira de controle do oídio do pimentão seria através de variedades com resistência genética.

Daubeze et al. (1989), avaliando a evolução da doença em acessos e gerações de C. annuum, cruzaram a linhagem resistente H3 com a suscetível Vania. Di-haploides foram obtidos de $\mathrm{F}_{1} \mathrm{~s}$ por cultura "in vitro" e tratados com colchicina. Quando 77 linhagens dihaploides foram comparadas com os parentais e respectivas gerações $F_{1}$ em condições de infecção artificiais, aproximadamente 18 foram equivalentes ao parental resistente. Pelo menos três genes estariam relacionados no controle da resistência.

Shifriss et al. (1992) avaliaram a linhagem HV-12, seu cruzamento com o parental 1646 suscetível, obtendo híbridos $F_{1}$, geração $F_{2}$ e retrocruzamentos. As reações dos materiais genéticos foram avaliadas sob condições epidêmicas de oídio na fase de frutificação. Os sintomas das plantas nas gerações $F_{1}, F_{2}$ e retrocruzamentos apareceram um mês mais tarde do que no parental suscetível. Postulou-se que a linhagem HV-12 teria dois mecanismos de resistência sendo um de restrição a colonização e disseminação do patógeno e outro de retenção foliar. As plantas híbridas $F_{1}$ foram todas intermediárias, sendo classificadas como moderadamente resistentes. Na geração $F_{2}$ num total de 410 plantas, 194 foram suscetíveis, 202 moderadamente resistentes e 14 foram resistentes. Quando o retrocruzamento foi feito para o parental suscetível, todas as 
plantas se mostraram suscetíveis, já o retrocruzado para o parental resistente HV-12 aumentou a freqüência gênica para resistência, sendo num total de 72 plantas avaliadas, cinco suscetíveis, 40 moderadamente resistentes e 27 resistentes. $\mathrm{O}$ autor concluiu que a resistência é controlada por três pares de genes recessivos independentes.

Daubeze et al. (1995) avaliaram a linhagem H3 resistente, seu híbrido obtido com a linhagem suscetível Vania, geração $F_{2}$ e retrocruzamentos. $O$ experimento foi conduzido em campo sob condições naturais de infecção na França e na Sicília (Itália). Foi avaliada a intensidade de esporulação com uma escala de 0 a 5 e a proporção da área foliar doente por planta de acordo com uma escala quantitativa de 0 a 5 . Os resultados mostraram que o $F_{1}$ teve nota intermediária em relação a seus parentais indicando uma herança quantitativa. A análise genética sugeriu que três fatores estariam envolvidos na fase inicial do ciclo de resistência do H3 ao oídio, caracterizando uma ação gênica parcialmente dominante para a suscetibilidade e cinco fatores envolvendo epistasia governariam esta resistência na fase final da epidemia. Estes resultados indicaram que a resistência é controlada por vários genes. Nas gerações $F_{2}$, e nos retrocruzamentos com o parental resistente foi observado um aumento da freqüência de plantas resistentes evidenciando que a resistência a L. taurica é oligogênica e de dominância incompleta.

Mulge \& Anand (1997) testaram a resistência ao oídio do pimentão usando linhagens e uma variedade comercial como testemunha. Observaram-se sintomas de oídio nos parentais e seus híbridos confirmando uma natureza dominante da resistência, a qual pode ser explorada em combinações heteróticas para produção.

Murthy \& Deshpande (1997), estudando a herança da resistência ao oídio, utilizaram cinco progenitores na produção de quatro híbridos; dois progenitores resistentes (PMR-10/95 K e II HR-1238), um moderadamente resistente (II HR-2200) e dois suscetíveis ao oídio (II HR-2881 e II HR-1515). As seis gerações desses cruzamentos foram reavaliadas para reação ao oídio sob alta pressão de inóculo. Os dados das reações foram sujeitos a um teste X-quadrado, teste de epistasia e análise de variância com base na média das seis gerações. A resistência ao oídio destas fontes indianas foi dominante mas controlada poligenicamente. Detectaram-se efeitos gênicos 
aditivos $\mathrm{x}$ aditivos em todos os quatro cruzamentos. Houve diferenças de alelismo quanto a resistência de PMR-10/95 K e II HR-1238.

Souza (2000), avaliou a reação a L. taurica em acessos do Banco de Germoplasma de Capsicum da Embrapa Hortaliças, além de híbridos e variedades comerciais. Identificaram-se oito acessos imunes: HV-12, 4638 e pimentas como ABE (CNPH 36), Kurimoto (CNPH 38), Nélio redonda (CNPH 50), Nélio fina 2 (CNPH 52), Escabeche (CNPH 279) e Malagueta (CNPH 288). Estabeleceu também uma hierarquia da reação de materiais comerciais sendo o híbrido Reinger foi classificado com medianamente resistente, Magnata, Elisa e Margarita suscetíveis, enquanto que Magali e California Wonder foram altamente suscetíveis. A maioria dos materiais (70\%) de Capsicum annuum foi moderadamente suscetível a L. taurica. Nas espécies C. baccatum, C. frutescens e $C$. chinense a situação foi diferente, ocorrendo maior número de acessos resistentes.

Lima (2002) verificou que na espécie C. annuum sob telado, 85\% dos acessos testados foram altamente suscetíveis e 10\% foram moderadamente suscetíveis. Um acesso foi moderadamente resistente (Sweet Pepper Blue Star), dois foram resistentes (MC-5 e WIR 2370), um foi altamente resistente (Pimenta) e apenas o HV-12 foi considerado imune. Em condições de casa de vegetação $68 \%$ dos acessos foram altamente suscetíveis e $20 \%$ moderadamente suscetível. Oito foram moderadamente resistentes (PI 187331, PI 1750, Myr 10, Hyb. Pepper- pep 1226-VP, 4090-P, 4109-P, 4665-P e Tico), um foi resistente (Bell Boy) e o acesso CNPH 1424, foi considerado altamente resistente.

Como revisado, existem relatos na literatura com referência a resistência de $C$. annuum ao patógeno, porém as poucas fontes de resistência encontradas não tem sido satisfatórias por apresentarem resistência parcial (Shifriss et al., 1992). Observou-se também que a herança da resistência nessa espécie não foi completamente elucidada. Devido a grande importância dessa doença e sabendo-se que atualmente $100 \%$ dos híbridos encontrados no mercado são altamente suscetíveis ao oídio visou-se através desse estudo: (a) triar os acessos da coleção de C. annuum da ESALQ/USP, identificando possíveis fontes de resistência nesta espécie e (b) obter maiores 
informações sobre a herança dessa resistência, para auxiliar programas de melhoramento genético visando obter variedades ou híbridos de pimentão resistentes ao oídio.

\subsection{Material e Métodos}

\subsubsection{Triagem da coleção de Capsicum annuum L.}

Visando fazer uma triagem da coleção de Capsicum da ESALQ/USP para identificar os materiais resistentes e os suscetíveis ao oídio, foram testados 99 acessos de C. annuum. Nas Tabelas 7 e 8, constam as identificações dos acessos e suas respectivas origens.

\subsubsection{Produção de mudas, condução, inoculação e avaliação}

O experimento foi instalado e conduzido em túnel de plástico alto, no Departamento de Produção Vegetal da Escola Superior de Agricultura "Luiz de Queiroz", no município de Piracicaba, SP, que está a uma latitude de $22^{\circ} 42^{\prime} 30^{\prime \prime}$ sul, longitude $47^{\circ} 38^{\prime} 00^{\prime \prime}$ oeste e uma altitude de $546 \mathrm{~m}$ (Kuabara, 1984). Segundo a classificação de Köppen, o clima da região é Cwa: subtropical úmido, com três meses mais secos (jun./jul./ago.), chuvas de verão e seca de inverno, temperatura do mês mais quente maior que $22^{\circ} \mathrm{C}$ e média de $21,4^{\circ} \mathrm{C}$.

A semeadura foi realizada em setembro de 2000, em bandejas de poliestireno expandido de 128 células, contendo substrato para hortaliças (Gioplant $($ ). Posteriormente as mudas foram transplantadas em dezembro de 2000 para vasos plásticos de oito litros contendo uma mistura na proporção de 3:2:1 de areia lavada, vermiculita e turfa.

O delineamento experimental foi em blocos casualizados com parcelas de uma planta por vaso e quatro repetições, totalizando 396 plantas.

A irrigação foi feita através de um sistema fechado de gotejamento no sistema intermitente, sendo acionado eletronicamente por um temporizador, regulado para atender o tempo de irrigação necessitado pelas plantas. Para o tutoramento das plantas foram instalados mourões de madeira de 2,0m de altura, onde foram esticados fitilhos ao 
longo das linhas de cultivo e as plantas foram presas a uma haste de bambu de $1 \mathrm{~m}$ em cada vaso.

A adubação foi feita através de fertirrigação usando na fase de muda o adubo Kristalon ${ }^{\circledR}$ 13-40-13, 1g/l visando um bom enraizamento das mesmas. Após o transplante foi usado o adubo Kristalon ${ }^{\circledR}$ 12-12-36 mais micronutrientes, nitrato de cálcio, $\mathrm{Ca} / \mathrm{B}$ e sulfato de magnésio, diluídos em 250 litros de água, aplicados duas vezes por semana. A adubação foi monitorada através da condutividade elétrica permanecendo em $1,7 \mathrm{EC}(1 \mathrm{~g} / 1 \mathrm{~L})$.

No controle preventivo de pragas e doenças foi utilizado Confidor ${ }^{\circledR}$ (Imidacloprid), Vertimec ${ }^{\circledR}$ (Abamectina) e Aplaud ${ }^{\circledR}$ (Buprofezin) nas dosagens recomendadas. Nenhum tipo de fungicida foi usado para não interferir na reação do hospedeiro ao patógeno.

O inóculo inicial foi obtido e mantido em plantas de pimentão suscetíveis e com alto grau de esporulação. As plantas disseminadoras e com inoculo primário de oídio foram intercaladas a cada quinze vasos (1:15) dos acessos de Capsicum a serem triados, permitindo assim uma eficiente disseminação e progresso da doença.

A avaliação da reação dos acessos ao oídio foi efetuada a partir do surgimento dos sintomas, iniciando-se na fase de frutificação. Foi utilizada uma escala de notas de acordo com a severidade da doença, proposta por Ullasa et al. (1981) (Tabela 1). O nível de severidade da doença foi estabelecido através do critério visual, folhas com diferentes expressões de sintomas foram coletadas e copiadas por um medidor de área foliar (Leaf Área Meter, modelo LI-3000 da Licor) obtendo-se a área foliar total e lesionada. Com base nessas medidas estimou-se a severidade da doença. Usando estes modelos referenciais, foi possível padronizar a avaliação da reação do hospedeiro através de notas de 1 a 5 (Tabela 1). As avaliações foram feitas a cada sete dias por seis semanas consecutivas.

Para melhor visualização, as fotografias colocadas no anexo B caracterizam as notas utilizadas de acordo com os estágios e severidade da doença. 
Tabela 1. Escala de notas para avaliação da reação de Capsicum à Leveillula taurica

\begin{tabular}{ccc}
\hline Notas & Sintomas & Reação \\
\hline 1 & Resistente, sem sintomas & $\mathrm{R}$ \\
2 & Moderadamente resistente, com 10\% da área foliar afetada & MR \\
3 & Moderadamente suscetível, com 11-20\% da área foliar afetada & MS \\
4 & Suscetível, com 21-50\% da área foliar afetada & $\mathrm{S}$ \\
5 & Altamente suscetível, com 51\% ou mais da área foliar afetada & $\mathrm{AS}$ \\
\hline
\end{tabular}

Adotou-se também testemunhas referenciais, cujas reações ao oídio são conhecidas na literatura e por produtores, para efeito comparativo na avaliação, monitoramento da epidemia e caracterização da reação dos acessos de pimenta e pimentão ao oídio (Tabela 2).

Tabela 2. Testemunhas referenciais de resistência e suscetibilidade de Capsicum annuum com relação a reação à Leveillula taurica

\begin{tabular}{clc}
\hline Hospedeiros referenciais & Procedência & Reação \\
\hline HV12 & INRA, França & $\mathrm{R}$ \\
Magali R & Sakata Agroflora & $\mathrm{S}$ \\
Margarita & Syngenta/Rogers & $\mathrm{S}$ \\
\hline
\end{tabular}

\subsubsection{Análise estatística}

Os dados obtidos nas seis avaliações foram submetidos à análise estatística pelo método GLIM, realizado com auxílio do Professor José Eduardo Corrente do Departamento de Ciências Exatas da ESALQ/USP. O software "GLIM" utiliza-se de um modelo logístico acumulado, onde se supõe que a distribuição original dos dados é Poisson. Deste modo, com as estimativas dos pontos de corte da análise original, caracterizou-se a reação dos acessos resistentes através das estimativas dos efeitos dos parâmetros (os acessos) ajustados e seus respectivos desvios-padrão.

As médias da sexta avaliação final foram submetidas também a Teste de Tukey a $5 \%$ de probabilidade, com o objetivo de comparar os resultados das duas análises. A análise de variância consta no anexo A. 


\subsubsection{Herança da reação}

Visando obter informações sobre a herança da reação ao oídio obtiveram-se estimativas do número de locos, coeficiente de herdabilidade, progresso esperado na seleção e o tipo de ação gênica envolvida. Híbridos entre progenitores resistentes também foram feitos com o objetivo de avaliar suas reações e determinar possível alelismo e expressões dos mecanismos de resistência dos progenitores.

\subsubsection{Estimação de parâmetros genéticos}

Com base na reação dos acessos ao oídio feita na primeira etapa de triagem, identificando as fontes de resistência e suscetibilidade, efetuaram-se cruzamentos de acessos resistentes x suscetíveis para determinação do modo de herança (Tabela 3). Na obtenção da geração $F_{1}$ foram utilizados seis progenitores os quais diferiram quanto a suas reações e características agronômicas descritas a seguir.

Pimentão HV-12 - Variedade obtida de um cruzamento entre uma cultivar de pimenta Etíope "H3" resistente e um pimentão tipo Lamuyo suscetível, "Vânia". Plantas haplóides foram obtidas a partir de cultura de anteras de plantas $F_{1}$. Posteriormente os haplóides androgeneticos foram diploidizados com uso de colchicina e selecionadas para resistência ao oídio. Apresenta frutos tipo cônico longo, 2 a 3 lóculos, polpa fina, sem valor comercial. É altamente resistente ao oídio.

Pimenta Chilli - Pimenta de frutos pequenos, com 2 lóculos, cônica vermelha, precoce, altamente pungente. É resistente ao oídio.

Pimenta \#124 - Pimenta originária de uma coleção da Filipinas, da Universidade da Filipinas, Los Baños. Possui frutos de formato cônico, bem pequenos, de 5 a $10 \mathrm{~cm}$, cor vermelho, bastante tardia. É resistente ao oídio.

Pimenta 609 - linhagem $\mathrm{F}_{5}$ derivada pelo método genealógico originalmente do híbrido experimental da Peto Seed PS 374594. É uma linhagem homozigótica para resistência ao PVY/PeMV (gene Pvr4) e TSWV (gene Sw). Possivelmente segrega para o gene Bs2 que confere resistência à Mancha Bacteriana Xanthomonas axonopodis, raças 1, 2 e 3). Seus frutos são tipo quadrado (Yolo Wonder), relação comprimento largura 1:1, fruto maduro vermelho, polpa grossa, quatro lóculos. Apresenta coloração amarelada das 
anteras e hipocótilo verde com completa ausência de antocianina na parte aérea e fruto maduro. É altamente suscetível ao oídio.

Pimentões 428 e 442 - linhagens $F_{4}$ derivadas por seleção genealógica do híbrido Commandant da firma Rogers, homozigóticas para resistência ao PVY/PeMV (gene Pvr4). Apresenta frutos tipo retangular, relação comprimento largura $2: 1$, de três a quatro lóculos e polpa grossa. Possui antocianina no hipocótilo e anteras com coloração púrpura. Originalmente o híbrido Commandant era resistente a Mancha bacteriana Xanthomonas axonopodis. São altamente suscetíveis ao oídio.

A hibridação foi feita com botões florais no estádio anterior à antese, através da emasculação eliminando-se as pétalas e anteras com auxílio de uma pinça histológica e posterior polinização dos botões florais antes da antese (Nuez et al., 1996). Cada botão polinizado foi identificado com uma etiqueta descrevendo o cruzamento. Os frutos resultantes da autofecundação foram eliminados para evitar a concorrência no desenvolvimento dos frutos $F_{1}$. Essas sementes híbridas foram produzidas entre os meses de abril e junho de 2001.

Tabela 3. Relação dos híbridos de pimentão e pimenta

\begin{tabular}{cc}
\hline Híbridos & Reações dos progenitores \\
\hline HV $-12 \times 609$ & resistente $\times$ suscetível \\
$442 \times$ HV -12 & suscetível x resistente \\
$428 \times$ HV -12 & suscetível x resistente \\
Chilli x 609 & resistente x suscetível \\
$\# 124 \times 609$ & resistente x suscetível \\
\hline
\end{tabular}

\subsection{Produção de mudas, condução, inoculação e avaliação dos híbridos $\left(F_{1}\right)$ e progenitores}

As mudas da geração $F_{1}$, progenitores e testemunhas suscetíveis foram obtidas em bandejas de poliestireno expandido usando substrato para hortaliças marca Gioplant ${ }^{\circledR}$. O transplante das mudas foi realizado no mês de outubro de 2001, para vasos plásticos de oito litros contendo mistura de solo, vermiculita e turfa, na proporção de 3:1:1. Os vasos 
foram colocados em quatro linhas duplas, com espaçamento de $1,0 \mathrm{~m}$ entre linhas na estufa.

Os tratos culturais foram os mesmos que os realizados no experimento de triagem, apresentados no item 3.2.1.1 O delineamento experimental foi inteiramente casualizado com parcelas de três plantas por vaso, três repetições e 13 tratamentos sendo cinco híbridos, seis progenitores e duas testemunhas suscetíveis, totalizando 117 plantas.

A inoculação, disseminação e avaliação, foram feitas do mesmo modo que o apresentado no item 3.2.1.1. Adotou-se o critério de suspender as avaliações quando as testemunhas referenciais de suscetibilidade, Magali $\mathrm{R}$ e Margarita, obtiveram nota máxima 5.

A geração $F_{1}$ foi avaliada em duas etapas, sendo a primeira na ocasião de sua obtenção e posteriormente na avaliação da geração $F_{2}$.

\subsection{Retrocruzamentos}

Visando aumentar a freqüência gênica e genotípica de plantas resistentes ao oídio, para finalidade de melhoramento e também contribuir para elucidar a herança da resistência, fez-se retrocruzamentos dos híbridos HV-12 x 609 e 442 x HV-12 para o progenitor resistente $\mathrm{HV}-12$.

Devido à falta de espaço na estufa, a geração de retrocruzamentos foi avaliada concomitantemente junto com a avaliação da espécie C. baccatum em janeiro de 2003.

\subsection{Produção de mudas, condução, inoculação e avaliação das gerações $F_{2}, F_{1}$, retrocruzamentos e progenitores}

A geração $F_{2}$ foi obtida a partir da autofecundação dos híbridos $\left(F_{1}\right)$.

Segundo a literatura, a herança que governa a resistência em Capsicum annuum L.

é complexa e poligênica (Daubeze et al., 1995 e Murthy \& Deshpande, 1997), sendo controlada por três genes recessivos (Shifriss et al, 1992). Com base nesta informação 
postulou-se que o tamanho ideal da população $F_{2}$ deveria ser em torno de 600 a 700 plantas para cada população $\mathrm{F}_{2}$ avaliada.

As semeaduras foram feitas em bandejas de poliestireno expandido, preenchida com substrato GII, da empresa Gioplanta. O transplante das mudas foi realizado no mês de maio de 2002 para vasos plásticos de oito litros, contendo substrato formulado pela Multiplanta Substrato Agrícola com a seguinte composição: casca de Pinus composta, granulação $10 \mathrm{~mm}$, vermiculita expandida, turfa processada, macro e micro nutrientes, fosfato super simples, Humix, areia (5\%) e elemento dispersante de umidade. Os tratos culturais realizados foram os mesmos das etapas anteriores. (item 3.2.1.1.).

O delineamento experimental foi inteiramente casualizado usando cinco plantas por vaso, totalizando 4.852 plantas (Tabela 4):

Tabela 4. Número de plantas (n) avaliadas por geração

\begin{tabular}{lclc}
\hline \multicolumn{1}{c}{ Gerações } & n & \multicolumn{1}{c}{ Gerações } & n \\
\hline$(\mathrm{HV}-12 \times 609) \mathrm{P}_{1}$ & 40 & $\left(\right.$ Chilli x 609) $\mathrm{P}_{1}$ & 45 \\
$\mathrm{P}_{2}$ & 39 & $\mathrm{P}_{2}$ & 39 \\
$\mathrm{~F}_{1}$ & 72 & $\mathrm{~F}_{1}$ & 25 \\
$\mathrm{~F}_{2}$ & 589 & $\mathrm{~F}_{2}$ & 735 \\
Retro $\mathrm{P}_{1}$ & 200 & & \\
$(442 \times \mathrm{HV}-12) \mathrm{P}_{1}$ & 52 & $(\# 124 \times 609) \mathrm{P}_{1}$ & 40 \\
$\mathrm{P}_{2}$ & 40 & $\mathrm{P}_{2}$ & 39 \\
$\mathrm{~F}_{1}$ & 65 & $\mathrm{~F}_{1}$ & 23 \\
$\mathrm{~F}_{2}$ & 700 & $\mathrm{~F}_{2}$ & 1093 \\
Retro $\mathrm{P}_{2}$ & 200 & & \\
$(428 \times \mathrm{HV}-12) \mathrm{P}_{1}$ & 37 & Testemunhas & \\
$\mathrm{P}_{2}$ & 40 & Magali R & 45 \\
$\mathrm{~F}_{1}$ & 26 & Margarita & \\
$\mathrm{F}_{2}$ & 633 & & \\
\hline
\end{tabular}


A inoculação, disseminação e avaliação, foram feitas do mesmo modo descrito no item 3.2.2.1.1; sendo que a proporção de linhas espalhadoras da doença neste experimento foi de 1:20. Foi feita apenas uma avaliação quando as plantas estavam em plena frutificação, determinando a reação da planta ao patógeno. Adotou-se o critério da avaliação quando as plantas testemunhas, Magali R e Margarita, atingiram nota máxima 5.

\subsection{Avaliação da qualidade e características dos frutos}

Os frutos das plantas $\mathrm{F}_{2}$ dos cruzamentos HV- 12 × 609, 442 x HV-12 e 428 x HV12 , que tiveram notas entre 1 e 2 para resistência; foram colhidos individualmente e caracterizados quanto suas qualidades, avaliando-se o comprimento em classes, curto, médio e longo; formato de acordo com a relação comprimento/largura, cônico, quadrado e retangular e número de lóculos. Amostras de frutos dos progenitores e geração $F_{1}$ correspondentes também foram colhidas e avaliadas quanto a qualidade de seus frutos. De acordo com esses parâmetros os frutos foram subdivididos nos seguintes tipos:

Cônico curto - Frutos de formato cônico com até $10 \mathrm{~cm}$ de comprimento e com dois a três lóculos.

Cônico médio (tipo híbrido Nathalie) - Frutos de formato cônico, 11 a $14 \mathrm{~cm}$ de comprimento, com dois a três lóculos.

Cônico longo (tipo híbrido Magali R) - Frutos de formato cônico, 14 a $16 \mathrm{~cm}$ de comprimento, com dois a três lóculos.

Quadrado (tipo Yolo Wonder) - Frutos de formato quadrado, relação comprimento-largura de 1:1, com quatro lóculos.

Retangular médio (tipo híbrido Máximo ou Margarita) - Frutos de formato retangular, relação comprimento-largura de 2:1, com três a quatro lóculos.

Retangular longo (tipo híbrido Valdor) - Frutos de formato retangular, relação comprimento-largura de 3:1, com três a quatro lóculos. 
$\mathrm{O}$ anexo $\mathrm{C}$ mostra a variabilidade de tipos de frutos obtidos na geração $\mathrm{F}_{2}$.

\subsection{Seleção}

\subsection{Produção de mudas, condução, inoculação e avaliação de gerações $F_{3}$}

Progênies $F_{3}$ dos cruzamentos HV-12 x 609, 442 x HV-12 e 428 x HV-12, cujas médias das gerações $F_{1}$ e $F_{2}$ foram melhores para resistência ao oídio, foram obtidas e selecionadas a partir de plantas da geração $\mathrm{F}_{2}$. Os caracteres avaliados para a seleção das plantas $F_{2}$ foram, plantas resistentes com notas 1 e 2 e tipos de frutos desejáveis nos diversos segmentos do mercado (descritos no item anterior). Os frutos maduros selecionados foram colhidos individualmente e as sementes obtidas constituíram as progênies $\mathrm{F}_{3}$. Nas etapas de seleção teve-se a seguinte situação: no cruzamento HV-12 x 609 , o número total de plantas avaliadas na geração $\mathrm{F}_{2}$ foi 589 sendo selecionadas 144 , o que corresponde a uma porcentagem de seleção de $24,4 \%$. Para o cruzamento 442 x HV12 o número total na geração $F_{2}$ foi de 700 plantas sendo selecionadas 231, o que corresponde a uma seleção de $33 \%$ e para $428 \times$ HV-12 o número total de plantas avaliadas na geração $F_{2}$ foi de 633 plantas sendo selecionadas 48 , sendo a porcentagem de seleção 7,6\%.

A semeadura das progênies foi realizada no mês de janeiro de 2003, em bandejas de 128 células. Com base na genealogia dos progenitores suscetíveis ao oídio 609, 442 e 428 e resistentes ao PVY/PeMV, praticou-se uma triagem prévia das progênies $\mathrm{F}_{3}$ para resistência ao PVY4m visando-se identificar a homozigosidade e heterogosidade da reação a virose. Segundo Palloix (1992), Boiteux et al. (1996) e Echer (2001), a herança ao PYY raça M é governada por um gene dominante, o que facilita sua incorporação e agregação com a resistência ao oídio.

O inóculo de PVY raça M para o teste foi obtido e fornecido por Echer (2001) já purificado, filtrado e multiplicado, na variedadede pimentão Magda. As plantas das progênies foram inoculadas duas vezes, nas folhas cotiledonares aos 29 dias após a semeadura e na terceira folha aos 36 dias após a semeadura. O modo de inoculação foi mecanicamente, usando como fonte de inóculo extratos de folhas de pimentão da 
cultivar Magda infectada. O extrato foi obtido através da maceração de folhas frescas com solução tampão de fosfato de potássio 0,02M ( $\mathrm{pH} 7$ ). A face superior das folhas a serem inoculadas, foi pulverizada com carborundum, e em seguida o inóculo foi aplicado através da fricção das folhas com algodão umedecido no extrato de folhas. Logo após a inoculação as folhas foram lavadas com água para remoção do excesso de inóculo (Nagai, 1983).

As avaliações foram realizadas aos 17 e 29 dias após a última inoculação, através da contagem das plantas com base na presença ou ausência de sintomas visuais. A reação de suscetibilidade foi caracterizada pela presença de sintoma sistêmico (mosaico ou mosqueado). As mudas que apresentaram sintomas do vírus foram eliminadas na fase de muda e as sem sintomas transplantadas para vasos plásticos de oito litros contendo substrato da Multiplanta Substratos Agrícolas ${ }^{\circledR}$. A condução e tratos culturais nessa fase foram semelhantes aos descritos nos itens anteriores (item . 3.2.1.1).

$\mathrm{Na}$ fase de frutificação, as plantas foram avaliadas para reação ao oídio da mesma forma já descrita nos itens anteriores para as gerações $F_{1}$ e $F_{2}$.

\subsection{Análise biométrica dos dados}

Para a realização das análises biométricas foram utilizados os dados das gerações, $\mathrm{P}_{1}, \mathrm{P}_{2}, \mathrm{~F}_{1}, \mathrm{~F}_{2}$. Como havia sido comentado anteriormente (item 3.2.2.1.1.), os progenitores $\mathrm{e}$ as gerações $\mathrm{F}_{1}$ foram avaliadas em duas etapas, na ocasião de sua obtenção e novamente junto a avaliação da geração $F_{2}$. Para que todas as gerações tivessem influência das mesmas condições ambientais, foram utilizados para o cálculo das análises os dados referentes a segunda avaliação.

O número de plantas dentro de cada classe de notas foi totalizado e a partir disso, estimadas as médias ponderadas [m], o somatório dos efeitos de aditividade [a] e dominância [d], usando o método de escala conjunta proposto por Cavali e descrito por Mather e Jinks (1981), baseado nas médias esperadas do caráter para as gerações, desconsiderando os efeitos epistáticos. Visando determinar os tipos de ação gênica 
envolvidas no modelo genético aditivo-dominante, tem-se os seguintes valores esperados:

$$
\begin{gathered}
\mathrm{E}\left[\overline{\mathrm{Y}}_{(\mathrm{PR})}\right]=\mathrm{m}-[\mathrm{a}] \\
\mathrm{E}\left[\overline{\mathrm{Y}}_{(\mathrm{PS})}\right]=\mathrm{m}+[\mathrm{a}] \\
\mathrm{E}\left[\overline{\mathrm{Y}}_{(\mathrm{F} 1)}\right]=\mathrm{m}+[\mathrm{d}] \\
\mathrm{E}\left[\overline{\mathrm{Y}}_{(\mathrm{F} 2)}\right]=\mathrm{m}+(1 / 2)[\mathrm{d}]
\end{gathered}
$$

Sendo: $\mathrm{m}=$ média geral do caráter;

[a] = somatório dos efeitos aditivos;

[d] = somatório dos efeitos de dominância;

$\mathrm{E}[\overline{\mathrm{Y}}]=$ esperança matemática da média das gerações $\mathrm{P}_{\mathrm{R}}$ (progenitor resistente), $\mathrm{P}_{\mathrm{S}}$ (progenitor suscetível), $\mathrm{F}_{1}, \mathrm{~F}_{2}$.

Admitindo que a maioria dos genes favoráveis para as características estudadas estão acumuladas em uma das linhagens genitoras e os desfavoráveis na outra e que as médias esperadas são expressáveis conforme acima, foi possível estimar os efeitos de m, [a] e [d] considerando as médias das diversas gerações.

Após o cálculo das variâncias foi feito um ajuste do número de graus de liberdade conjunto, para citações de heterogeneidade nas variâncias das gerações conforme Gomes (1990).

A adequação do modelo genético aditivo-dominante, adotado com base nos três parâmetros, m, [a] e [d] foi verificada pelo teste t por meio de contrastes entre médias segundo Gomes (1990). Nesses testes comparou-se a média observada da geração $F_{2}$ com seu valor esperado, conforme o modelo. Em caso de significância do teste t, adotouse modelo com efeitos epistáticos, componentes das médias das gerações $(\mathrm{PR}=\mathrm{m}-[\mathrm{a}]+$ [i]; PS $=\mathrm{m}+[\mathrm{a}]+[\mathrm{i}] ; \mathrm{F}_{1}=\mathrm{m}+[\mathrm{d}]+[1]$ e $\left.\mathrm{F}_{2}=\mathrm{m}+(1 / 2)[\mathrm{d}]+(1 / 4)[1]\right)$, além dos efeitos aditivo e dominante. Para mensurar esses efeitos, considerou-se o conteúdo genético do contraste:

$$
\mathrm{C}=\overline{\mathrm{Y}}_{\mathrm{F} 2}-(1 / 4)\left(\overline{\mathrm{Y}}_{\mathrm{PR}}+\overline{\mathrm{Y}}_{\mathrm{PS}}+2 \overline{\mathrm{Y}}_{\mathrm{F} 1}\right)
$$


Cuja esperança matemática é

$$
\mathrm{E}(\mathrm{C})=(1 / 2)[\mathrm{i}]+(1 / 4)[1]
$$

Nesta esperança de C, o parâmetro [i] é a soma dos efeitos epistáticos do tipo aditivo $\mathrm{x}$ aditivo e o parâmetro [1] a soma dos efeitos epistáticos do tipo dominante $\mathrm{x}$ dominante (Mather e Jinks, 1981). Evidentemente E(C) será nula no caso de ausência de efeitos epistáticos. No modelo epistático não foi usada da geração retrocruzamento, pois esta foi avaliada em época diferente a da geração $\mathrm{F}_{2}$, além do mais se sabe que o oídio é uma doença bastante influenciada pelo ambiente.

Foram construídos histogramas de distribuição de freqüência de plantas para a realização de uma análise exploratória dos dados, com o intuito de visualizar melhor o comportamento das médias dentro de cada classe de notas nas diferentes gerações.

$\mathrm{O}$ número de locos segregantes na geração $\mathrm{F}_{2}$ foi estimado somente para casos onde as reações dos progenitores eram contrastantes, de duas formas. Com base na freqüência dos extremos resistentes manifestados no genitor resistente em cada cruzamento e baseado na fórmula para número mínimo de genes segregantes de Burton (1951):

$$
\mathrm{n}_{\mathrm{g}}=\frac{0,25\left(0,75-\beta+\beta^{2}\right) \alpha^{\underline{2}}}{\sigma_{\mathrm{g}}^{2}}
$$

Onde, $\alpha=\mathrm{P}_{2}-\mathrm{P}_{1}$, sendo $\mathrm{P}_{2}$ a média do progenitor mais alto, $\beta=\left(\mathrm{F}_{1}-\right.$ $\left.\mathrm{P}_{1}\right) / \alpha$, sendo $F_{1}$ e $P_{1}$, as médias das gerações $F_{1}$ e do progenitor 1 e $\sigma_{g}^{2}$ a variância genética em $\mathrm{F}_{2}$.

Podem ocorrer diferenças na estimativa do número de genes calculada pela freqüência e pela fórmula. Pela fórmula, se está mais sujeito a possibilidade de erros de estimação, pois ela envolve um número de estimativas (médias e variâncias) maior se comparado ao método das freqüências. Convém observar que a expressão de $\mathrm{n}_{g}$ subestima o número de locos segregantes na presença de ligação gênica e nos casos em que as linhagens progenitoras não são completamente contratantes. Apesar disso os dois procedimentos foram usados para confrontar e reforçar os resultados. 
Os coeficientes de herdabilidade também foram calculados para cada cruzamento de acordo com Vencovsky \& Barriga (1992), conforme segue:

$$
\mathrm{h}^{2}=\sigma_{\mathrm{g}}^{2} / \sigma_{\mathrm{f}}^{2}
$$

onde, $\mathrm{h}^{2}=$ coeficiente de herdabilidade

$\sigma_{\mathrm{g}}^{2}=$ variância genética

$\sigma_{\mathrm{f}}^{2}=$ variância fenotípica

A variância genética e a variância fenotípica foram estimadas por:

$$
\begin{gathered}
\sigma_{\mathrm{g}}^{2}=\sigma_{\mathrm{F} 2}^{2}\left[\left(\sigma_{\mathrm{P} 1}^{2}+\sigma_{\mathrm{P} 2}^{2}+2 \sigma_{\mathrm{F} 1}^{2}\right) / 4\right] \\
\sigma_{\mathrm{f}}^{2}=\sigma_{\mathrm{F} 2}^{2}
\end{gathered}
$$

A partir dos coeficientes de herdabilidade foram calculados os ganhos de seleção esperados para a geração $F_{3}$. Simulou-se seleção das plantas com notas 1 e 2 .

$$
\mathrm{Gs} \leq \mathrm{ds} \cdot \mathrm{h}^{2}
$$

Onde, Gs = ganho de seleção

ds = diferencial de seleção

$\mathrm{h}^{2}=$ coeficiente de herdabilidade

Sendo o diferencial de seleção calculado por:

$$
\mathrm{ds}=\overline{\mathrm{y}}_{\mathrm{s}}-\overline{\mathrm{Y}}_{\mathrm{F} 2}
$$

Onde, $\overline{\mathrm{y}}_{\mathrm{s}}=$ média geral das progênies selecionadas.

$\overline{\mathrm{y}}_{\mathrm{F} 2}=$ média da geração $\mathrm{F}_{2}$.

Os coeficientes de herdabilidade e os ganhos de seleção foram calculados com base na herdabilidade no sentido amplo. Essa estimativa do progresso (Gs) é adequada em casos de ausência de dominância. Havendo evidência de dominância o valor de Gs estará super estimado, servindo apenas como referencial.

$\mathrm{O}$ progresso observado na geração $\mathrm{F}_{3}$ com a seleção de plantas notas 1 e 2 (resistentes) foi calculado pela diferença entre a média observada na geração $F_{3}$ com a seleção e a média esperada na geração $F_{3}$ sem seleção. Sendo a média esperada na geração $\mathrm{F}_{3}$ sem seleção dada por: 


$$
\begin{gathered}
\mathrm{F}_{3} \text { (esper). }=\mathrm{MP}+[(\mathrm{F} 2-\mathrm{MP}) / 2] \text { ou } \\
\mathrm{F}_{3} \text { (esper). }=\mathrm{MP}+1 / 4 \mathrm{H}
\end{gathered}
$$

Onde, MP é a média dos progenitores, $F_{2}$ é a média da geração $F_{2}$ observada e $H$ é heterose.

As análises biométricas foram feitas com auxílio do Prof. Dr. Roland Vencovsky do Departamento de Genética da ESALQ/USP.

\subsubsection{Reação de híbridos resistentes ao oídio em C. annuum}

Visando determinar a existência de alelismo ou não entre as fontes de resistência identificadas; foram feitos cruzamentos entre esses progenitores com posterior obtenção das gerações segregantes (Tabela 5). Foram utilizados três progenitores, HV-12, \#124 e Chilli. Suas características assim como o modo de hibridação estão descritos no item 3.2.2.1.

Tabela 5. Relação dos híbridos

\begin{tabular}{cc}
\hline Híbridos & Reações dos progenitores \\
\hline$\# 124 \times \mathrm{HV}-12$ & resistente $\mathrm{x}$ resistente \\
Chilli x HV-12 & resistente $\mathrm{x}$ resistente \\
\hline
\end{tabular}

\subsection{Produção de mudas, condução, inoculação e avaliação dos híbridos $\left(F_{1}\right)$ e progenitores}

A produção das mudas e tratos culturais foram feitos do mesmo modo que o descrito no item 3.2.1.1. O delineamento experimental foi inteiramente casualizado usando três plantas por vaso, três repetições e sete tratamentos sendo, dois híbridos, três progenitores e duas testemunhas suscetíveis, totalizando 63 plantas.

Os critérios de inoculação e o modo de avaliação das reações foram os mesmos apresentados no item 3.2.1.1 


\subsection{Produção de mudas, condução, inoculação e avaliação $\operatorname{dos} F_{2}, F_{1}$, e progenitores}

A produção das mudas das gerações $F_{2}, F_{1}$ e progenitores e os tratos culturais foram semelhantes ao já relatado no item 3.2.1.1. O delineamento experimental foi inteiramente casualizado utilizando-se cinco plantas por vaso, totalizando 2.104 plantas: (Tabela 6):

Tabela 6. Número de plantas avaliadas por geração

\begin{tabular}{lc}
\hline \multicolumn{1}{c}{ Gerações } & $\mathbf{N}^{\mathbf{0}}$ de plantas \\
\hline$\left(\#\right.$ 124 x HV-12) $\mathrm{P}_{1}$ & 40 \\
$\mathrm{P}_{2}$ & 40 \\
$\mathrm{~F}_{1}$ & 55 \\
$\mathrm{~F}_{2}$ & 928 \\
$\left(\right.$ Chilli x HV-12) $\mathrm{P}_{1}$ & 45 \\
$\mathrm{P}_{2}$ & 40 \\
$\mathrm{~F}_{1}$ & 61 \\
$\mathrm{~F}_{2}$ & 815 \\
Testemunha Magali R & 45 \\
Testemunha Margarita & 45 \\
\hline
\end{tabular}

A inoculação, disseminação e avaliação, foram feitas do mesmo modo que o descrito no item 3.2.2.1.1.

\subsection{Análise biométrica dos dados}

Feita as avaliações, o número de plantas dentro de cada classe de notas foi totalizado e estimadas as médias ponderadas [m], o somatório dos efeitos de aditividade [a] e dominância [d] visando verificar a presença dos efeitos envolvidos no modelo genético aditivo-dominante. Verificou-se a adequação do modelo pelo teste t por meio de contrastes entre médias segundo Gomes (1990). Em caso de significância do teste t, 
adotou-se modelo com efeitos epistáticos. Um melhor detalhamento dessa análise foi descrito no item 3.2.2.1.5

Histogramas de distribuição das gerações foram feitos para visualizar melhor o comportamento das médias dentro de cada classe de notas nas diferentes gerações.

\subsection{Resultados e Discussão}

\subsubsection{Triagem da coleção de capsicum annuum $\mathrm{L}$.}

Dos acessos de C. annuum testados, apenas 5\% do total foram considerados resistentes ao oídio (L. taurica). Essa baixa freqüência de fontes de resistência ao oídio em C. annuum concorda com Lima (2002) e Souza \& Café-Filho (2003). Pela análise GLIM apenas os acessos que apresentaram as menores notas (1 a 3), e que as mantiveram constantes ao longo das avaliações foram considerados resistentes (Tabela 7, Figura 1). O período de latência é um importante parâmetro na expressão da reação de resistência do hospedeiro. No caso do oídio, o progresso da doença obedece às características de progresso temporal típicas de doenças policíclicas sensu. A taxa de progresso é consistentemente reduzida de acordo com o nível de resistência horizontal do hospedeiro (Souza, 2000).

O acesso HV-12, já descrito por Bechir (1993), Shifriss et al., (1992), Daubeze et al., (1995), Souza (2000) e Lima (2002), confirmou-se o mais resistente sem nenhum sintoma, mantendo nota 1 da $1^{\text {a }}$ até a última avaliação; destacando-se assim como a melhor fonte e tipo de resistência a ser usada no melhoramento de pimentão à L. taurica (Tabela 7, Figura 1). Segundo Shifriss et al., (1992), o HV-12 tem dois mecanismos de resistência ao oídio, sendo um de resistência à inoculação e disseminação e outro relacionado com a capacidade de retenção foliar sob alta pressão do patógeno (foto anexo D).

Além do HV-12, dois acessos se destacaram como fontes de resistência na espécie C. annuum, Chilli e \#124, que apresentaram médias 1,75 e 2,25 (Tabela 7, Figura 1). Além dessas duas pimentas resistentes ao oídio, outras como Jalapeno 2 e Catie 8063, apresentaram uma reação diferenciada do HV-12, denominada "fleck" (manchas necróticas) resultante de um tipo de reação de hipersensibilidade do hospedeiro ao 
patógeno, como um possível e efetivo mecanismo de defesa. A planta pode ser infectada pelo patógeno, porém os sintomas se restringem a pontuações, micro-lesões necróticas sem esporulação (foto anexo D). O mecanismo de hipersensibilidade do hospedeiro restringe a esporulação e disseminação do patógeno, como descrito por Carver et al. (1995) e Zeyen et al. (1995). Segundo os mesmos autores, nesta reação ocorre morte celular no local de penetração do patógeno. A morte celular é associada a gene (s) maior (es) condicionando incompatibilidade hospedeiro-patógeno. Esta reação se restringe geralmente à célula epidérmica diretamente colonizada, porém as células adjacentes e do mesófilo também podem morrer em conseqüência da patogênese. De acordo com Lima (2002), genótipos resistentes apresentam períodos de latência mais prolongados caracterizados pela presença de manchas cloróticas que progridem para necroses bem delimitadas.

Esta reação de manchas necróticas ocorre quando existe uma forte pressão do patógeno. É uma situação experimental quando existe grande proporção de acessos suscetíveis em relação aos resistentes, havendo uma alta pressão de inóculo. Em condições de cultivos isolados, sem pressão de inóculo, esses acessos poderiam exibir resistências equivalentes a do HV-12. Este fenômeno de interferência de parcelas é amplamente conhecido na literatura sobre resistência de hospedeiros à patógenos.

Os demais acessos da coleção foram suscetíveis, geralmente com média de notas 5 a partir da terceira avaliação, concordando com Shifriss et al., (1992), Stadnik \& Rivera (2001). Entre os acessos altamente suscetíveis testados neste trabalho, que também foram testados por Lima (2002) com equivalente reação, estão PI 187331, Myr 10 e Myr 29. (Tabela 8).

Entre os híbridos comerciais testados, Reinger, Natalie, Margarita, Magali R e Magda, foram classificados como suscetíveis (nota 4) a altamente suscetíveis (nota 5), concordando com os resultados relatados por Lima (2002) e Souza (2000). Convém destacar que Souza (2000), relatou que o híbrido de pimentão Reinger foi moderadamente resistente, o que não foi observado, pois o mesmo mostrou-se altamente suscetível. 
Uma das possíveis explicações do fato de que a suscetibilidade ao oídio é comum em C. annuum poderia ser devido ao seu processo de domesticação, onde os genes que conferem resistência foram perdidos durante o processo de seleção (Reifschneider et al., 2000). O desenvolvimento de variedades e híbridos de pimentão restringiram a variabilidade e aumentaram a vulnerabilidade à doenças.

Tabela 7. Relação dos acessos resistentes e médias de suas reações em cada avaliação.

C. annuum. 2001

\begin{tabular}{llcccccc}
\hline & & \multicolumn{7}{c}{ Média de notas por avaliação (Dias) } \\
\multicolumn{1}{c}{ Acessos } & Origem & $\mathbf{7}$ & $\mathbf{1 4}$ & $\mathbf{2 1}$ & $\mathbf{2 8}$ & $\mathbf{3 5}$ & $\mathbf{4 2}$ \\
\hline HV-12 & INRA & 1,00 & 1,00 & 1,00 & 1,00 & 1,00 & $1,00 \mathrm{E}$ \\
Chilli & Índia & 1,00 & 1,75 & 1,75 & 1,75 & 1,75 & $1,75 \mathrm{DE}$ \\
$\# 124$ & Filipinas & 1,50 & 2,00 & 2,00 & 2,00 & 2,00 & $2,25 \mathrm{CDE}$ \\
Catie 8063 & Costa Rica & 1,25 & 1,25 & 2,25 & 2,25 & 2,75 & $3,00 \mathrm{ABCDE}$ \\
Jalapeño 2 & Brasil & 1,25 & 1,25 & 2,25 & 2,75 & 3,00 & $3,00 \mathrm{ABCDE}$ \\
\hline
\end{tabular}

1. Médias seguidas pela mesma letra na coluna, não diferem entre si, ao nível de $5 \%, 1,25$ pelo teste de Tukey.

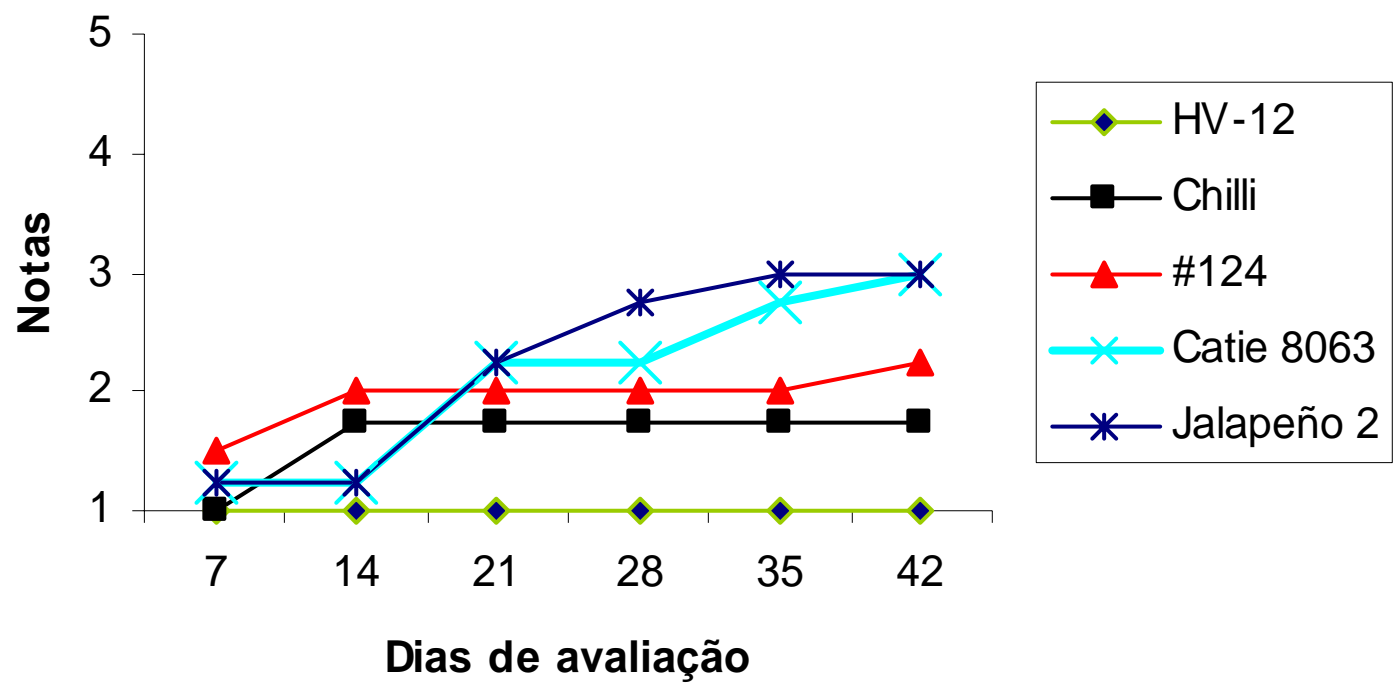

Figura 1 - Progresso da doença dos acessos resistentes de C. annuum L 
Tabela 8. Relação dos acessos suscetíveis e médias de suas reações. C. annuum. 2001

\begin{tabular}{|c|c|c|}
\hline Acessos & Origem & Médias $^{1}$ \\
\hline CNPH 32 & Brasil & $3,00 \mathrm{ABCD}$ \\
\hline BGH 3884 & Brasil & $3,00 \mathrm{ABCD}$ \\
\hline \# 138 & Filipinas & $3,00 \mathrm{ABCD}$ \\
\hline BGH 3883 & Brasil & $3,00 \mathrm{ADCD}$ \\
\hline BGH 3759 & Brasil & $3,00 \mathrm{ABCD}$ \\
\hline Morrones & Portugal & $3,25 \mathrm{ABCD}$ \\
\hline Mulato Dulce & Portugal & $3,25 \mathrm{ABCD}$ \\
\hline Calahora & México & $3,50 \mathrm{ABCD}$ \\
\hline CNPH 185 & Brasil & $3,50 \mathrm{ABCD}$ \\
\hline IAC \#218 & Colômbia & $3,50 \mathrm{ABCD}$ \\
\hline IAC \#63 & Colômbia & $3,50 \mathrm{ABCD}$ \\
\hline Ají Rojo \#258 & Bolívia & $3,50 \mathrm{ABCD}$ \\
\hline BGH 3717 & Brasil & $3,75 \mathrm{ABCD}$ \\
\hline Mexicana Tosello & México & $3,75 \mathrm{ABCD}$ \\
\hline Arivivi \# 142 & Bolívia & $3,75 \mathrm{ABCD}$ \\
\hline Magda & Agroflora & $3,75 \mathrm{ABCD}$ \\
\hline \# 125 & Filipinas & $4,00 \mathrm{ABC}$ \\
\hline Mulato V-2 & México & $4,00 \mathrm{ABC}$ \\
\hline Catie 7300 \#121 & Costa Rica & $4,00 \mathrm{ABC}$ \\
\hline Malagueta & Brasil & $4,00 \mathrm{ABC}$ \\
\hline Argentina \#3 & Brasill & $4,00 \mathrm{ABC}$ \\
\hline CNPH 40 & Brasil & $4,00 \mathrm{ABC}$ \\
\hline Jalapeno 3 & Brasil & $4,00 \mathrm{ABC}$ \\
\hline BGH 3886 & Brasil & $4,00 \mathrm{ABC}$ \\
\hline Marconi & USA & $4,00 \mathrm{ABC}$ \\
\hline ICA \#64 & Colômbia & $4,00 \mathrm{ABC}$ \\
\hline Magali R & Agroflora & $4,00 \mathrm{ABC}$ \\
\hline Ano todo & Brasil & $4,25 \mathrm{ABC}$ \\
\hline BGH 3058 & Brasil & $4,25 \mathrm{ABC}$ \\
\hline CNPH 144 & Brasil & $4,25 \mathrm{ABC}$ \\
\hline Florida VR-4 & USA & $4,25 \mathrm{ABC}$ \\
\hline Kancluster & USA & $4,25 \mathrm{ABC}$ \\
\hline PI 187331 & USA & $4,25 \mathrm{ABC}$ \\
\hline BGH 3758 & Brasil & $4,25 \mathrm{ABC}$ \\
\hline Pimenta verde & Brasil & $4,25 \mathrm{ABC}$ \\
\hline Avelar & Brasil & $4,50 \mathrm{AB}$ \\
\hline BGH 3058 & Brasil & $4,50 \mathrm{AB}$ \\
\hline BGH 3464 & Brasil & $4,50 \mathrm{AB}$ \\
\hline BGH 3743 & Brasil & $4,50 \mathrm{AB}$ \\
\hline BGH 3888 & Brasil & $4,50 \mathrm{AB}$ \\
\hline Maalab & Filipinas & $4,50 \mathrm{AB}$ \\
\hline PI 188476 & USA & $4,50 \mathrm{AB}$ \\
\hline
\end{tabular}


Tabela 8. Relação dos acessos suscetíveis e médias de suas reações. C. annuum. 2001

\begin{tabular}{|c|c|c|}
\hline Acessos & Origem & Médias ${ }^{1}$ \\
\hline $\mathrm{R}-17$ & Filipinas & $4,50 \mathrm{AB}$ \\
\hline BG 3883 & Brasil & $4,50 \mathrm{AB}$ \\
\hline BGH 5112 & Brasil & $4,50 \mathrm{AB}$ \\
\hline Ancho & México & $4,75 \mathrm{AB}$ \\
\hline BGH 3756 & Brasil & $4,75 \mathrm{AB}$ \\
\hline BGH 4016 & Brasil & $4,75 \mathrm{AB}$ \\
\hline IAC 8 Mogi & Colômbia & $4,75 \mathrm{AB}$ \\
\hline IAC \# 132 & Colômbia & $4,75 \mathrm{AB}$ \\
\hline Myr 29 & Brasil & $4,75 \mathrm{AB}$ \\
\hline BGH 3887 & Brasil & $4,75 \mathrm{AB}$ \\
\hline Khomernhu & Bolívia & $4,75 \mathrm{AB}$ \\
\hline Locarte & Paraguai & $4,75 \mathrm{AB}$ \\
\hline Reinger & Syngenta & $4,75 \mathrm{AB}$ \\
\hline Natalie & Syngenta & $4,75 \mathrm{AB}$ \\
\hline Margarita & Syngenta & $4,75 \mathrm{AB}$ \\
\hline$\# 132$ & Filipinas & $5,00 \mathrm{~A}$ \\
\hline \#36 & Filipinas & $5,00 \mathrm{~A}$ \\
\hline$\# 5$ & Brasil & $5,00 \mathrm{~A}$ \\
\hline Agronomico 10 & Brasil & $5,00 \mathrm{~A}$ \\
\hline BGH 3744 & Brasil & $5,00 \mathrm{~A}$ \\
\hline BGH 3890 & Brasil & $5,00 \mathrm{~A}$ \\
\hline BGH 3896 & Brasil & $5,00 \mathrm{~A}$ \\
\hline BGH 3878 & Brasil & $5,00 \mathrm{~A}$ \\
\hline BGH 3978 & Brasil & $5,00 \mathrm{~A}$ \\
\hline BGH 3464 & Brasil & $5,00 \mathrm{~A}$ \\
\hline BGH 3757 & Brasil & $5,00 \mathrm{~A}$ \\
\hline BGH 3881 & Brasil & $5,00 \mathrm{~A}$ \\
\hline BGH 3889 & Brasil & $5,00 \mathrm{~A}$ \\
\hline BGH 3891 & Brasil & $5,00 \mathrm{~A}$ \\
\hline Caprioglio & Itália & $5,00 \mathrm{~A}$ \\
\hline Catarino Cascabel & México & $5,00 \mathrm{~A}$ \\
\hline CNPH 145 & Brasil & $5,00 \mathrm{~A}$ \\
\hline CNPH 146 & Brasil & $5,00 \mathrm{~A}$ \\
\hline CNPH 162 & Brasil & $5,00 \mathrm{~A}$ \\
\hline CNPH 294 & Brasil & $5,00 \mathrm{~A}$ \\
\hline Corno di Toro & Itália & $5,00 \mathrm{~A}$ \\
\hline El Saltenito & México & $5,00 \mathrm{~A}$ \\
\hline IAC \#12 & Colômbia & $5,00 \mathrm{~A}$ \\
\hline IAC \# 131 & Colômbia & $5,00 \mathrm{~A}$ \\
\hline Jalapeño 1 & México & $5,00 \mathrm{~A}$ \\
\hline Jalapeño (cica) $\mathrm{N}^{\mathrm{o}} 1$ & México & $5,00 \mathrm{~A}$ \\
\hline Myr 10 & Brasil & $5,00 \mathrm{~A}$ \\
\hline
\end{tabular}


Tabela 8. Relação dos acessos suscetíveis e médias de suas reações. C. annuum. 2001

\begin{tabular}{lcc}
\hline \multicolumn{1}{c}{ Acessos } & Origem & Médias $^{\mathbf{1}}$ \\
\hline Pimenta Orn. Picante P01 & Brasil & $5,00 \mathrm{~A}$ \\
Pimenta Picante P001 & Brasil & $5,00 \mathrm{~A}$ \\
Pimenta Roque & México & $5,00 \mathrm{~A}$ \\
$\# 17$ & Filipinas & $5,00 \mathrm{~A}$ \\
BG 3757 & Brasil & $5,00 \mathrm{~A}$ \\
RFG/FAO \#858 & Guatemala & $5,00 \mathrm{~A}$ \\
Pimenta Doce IH-1744 & Brasil & $5,00 \mathrm{~A}$ \\
Arivivi \#261 & Bolívia & $5,00 \mathrm{~A}$ \\
Pimenta Ornamental & Brasil & $5,00 \mathrm{~A}$ \\
Ají-Rojo 265 & Bolívia & $5,00 \mathrm{~A}$ \\
\hline 1. Médias seguidas pela mesma letra na coluna, não diferem entre si, ao nível de 5\%, pelo teste de Tukey.
\end{tabular}

\subsubsection{Herança da reação}

\subsubsection{Estimação de parâmetros genéticos}

Os progenitores confirmaram os mesmos tipos de reações já apresentadas na etapa de triagem. O HV-12 comportou-se como altamente resistente (nota 1) e as duas outras fontes de resistência encontradas, Chilli e \#124, confirmaram suas reações típicas de hipersensibilidade anteriormente descritas (item 3.3.1) (Tabela 9).

A resistência da variedade HV-12 é duradoura e consistente, sua reação no Brasil funcionou tanto para os isolados de L. taurica em Piracicaba/SP (Blat, 2002), como de Brasília/DF (Souza, 2000 e Lima, 2002). Foi também resistente na Tunísia (Bechir, 1993), Israel (Shifriss et al., 1992), França e Itália (Daubeze et al., 1995). É uma forte evidência de que as populações de L. taurica não são variáveis em sua patogenicidade e agressividade. A reação do HV-12 até o presente momento tem sido relatada como consistente e estável, sem evidências de que sua resistência tenha sido superada por raças mais patogênicas de L. taurica. Esse tipo de resistência é altamente desejável para ser explorada no melhoramento genético visando obter variedades e híbridos resistentes ao oídio.

Os progenitores 609, 442 e 428, mantiveram sua alta suscetibilidade, apresentando nota máxima 5 com médias 5,00 nas primeiras avaliações tanto nos experimento de triagem e de obtenção da geração $F_{1}$ e posteriormente 4,64, 4,56 e 4,60 na segunda avaliação na avaliação da geração $\mathrm{F}_{2}$ (Tabela 10). Todas essas linhagens de pimentão 
apresentam resistência às viroses PVYm (gene Pvr4), TSWV (gene Sw) e TMV (gene L1) podendo posteriormente em gerações mais avançadas, serem selecionadas e agregadas concomitantemente com a resistência ao oídio.

As testemunhas suscetíveis, Magali $\mathrm{R}$ e Margarita e os progenitores suscetíveis apresentaram intensa esporulação seguida de forte defoliação e queimadura dos frutos pelo sol.

Os híbridos HV-12 x 609, 442 x HV-12 e 428 x HV-12, nas duas avaliações tiveram o maior número de plantas concentrado na nota 3 , sendo uma reação intermediária em relação a dos progenitores, (Tabela 9, fig. 2 a 4) com médias 3,00, 3,44 e 3,55 na primeira avaliação e 2,87, 3,00 e 3,58 na segunda avaliação respectivamente (Tabela 10), concordando com Shifriss et al. (1992). Segundo Daubeze et al. (1995), o retardamento na expressão de suscetibilidade das linhagens sugere que a expressão dos genes de resistência incompletos ou de resistência parcial, pode ser progressivamente revelada com o tempo e depende de ocorrência de infecção secundária. Convém destacar que a avaliação precoce pode revelar fenótipos com reação intermediária, mas somente uma avaliação tardia é que pode detectar e identificar acessos altamente resistentes, similares ao HV-12.

São bastante contrastantes as reações intermediárias de resistência desses híbridos quando comparados com o progresso da doença das linhagens suscetíveis que rapidamente chegam à nota máxima 5. Esta reação intermediária observada na geração $\mathrm{F}_{1}$ poderá ser valiosa no controle integrado do oídio se for associada com o uso de fungicidas ou algum controle alternativo, como leite de vaca, bicarbonato de sódio e fosfato monopotássico.

Nota-se que as reações das plantas dos cruzamentos Chilli x 609 e \#124 x 609, cujos progenitores resistentes diferiram do HV-12, foram mais suscetíveis apresentando médias nas gerações $F_{1}$ de 4,96 e 4,17 na segunda avaliação, e para as gerações $F_{2}$ de 4,74 e 4,00 respectivamente, evidenciando e confirmando com isso que a escolha do progenitor tem grande influência nos resultados dos cruzamentos e no sucesso de um programa de melhoramento (Tabela 10). Ao se observar a distribuição de indivíduos $\mathrm{F}_{2}$ dentro das diferentes classes verificou-se que para os cruzamentos HV-12 x 609, 442 x 
HV-12 e 428 x HV-12 a maior proporção de plantas esteve entre as classes 2 e 3 com $66,8 \%, 75,6 \%$ e 50,7\% e para, Chilli x 609 e \#124 x 609 a maior proporção mostrou-se na classe 5 , com 83,0\% e 46,7\% respectivamente (Figuras de 2 a 6).

A análise genética das gerações mostrou ausência de dominância no cruzamento HV-12 x 609, indicando ação gênica apenas aditiva, nos locos para os quais as linhagens diferem (Tabela 11). Apesar da falta de manifestação da dominância, não se pode afirmar que ela inexista. As médias que usamos para determinar a heterose são funções lineares de efeitos genéticos. Portanto, podem existir efeitos de sinais opostos que resultem em cancelamento dos mesmos, não havendo suas manifestações na expressão fenotípica. Os demais cruzamentos 442 x HV-12, 428 x HV-12, Chilli x 609 e \#124 x 609 apresentaram um valor de heterose significativo em relação à média dos pais, indicando a manifestação de dominância nos locos cuja atividade interfere no caráter ou que ela ocorre em uma parcela desses locos (Tabela 2). Em todos os cruzamentos que exibiram ação gênica dominante altamente significativa manifestaram na segregação em $\mathrm{F}_{2}$ efeitos epistáticos, demonstrando interação gênica, quando testados para este modelo, concordando com Daubeze et al. (1995). (Tabela 11). A base genética do caráter de resistência apresentada nos diversos cruzamentos mostra ter locos com graus de dominância variáveis, demonstrando ser uma herança complexa.

A dominância apresentada tendeu à suscetibilidade, indicando que a resistência é recessiva, concordando com os resultados obtidos por Shifriss et al (1992), Daubeze et al (1995). As médias das gerações $F_{2}$ foram de 2,79 (442 x HV-12), 3,48 (428 x HV-12), 4,74 (Chilli x 609) e 4,00 (\# 124 x 609) (Tabela 10). Desse modo, uma vez que o melhorista seleciona plantas resistentes, automaticamente estará avançando somente plantas homozigóticas, o que torna bastante eficiente o método seletivo.

Com base nestes resultados pode-se concluir que o componente genético da variância do cruzamento HV-12 x $609\left(\sigma_{\mathrm{g}}^{2}=\sigma_{\mathrm{a}}^{2}\right)$ é simplesmente aditiva e que nos demais cruzamentos esse componente contém efeitos aditivos, dominantes e epistático. $\left(\sigma^{2} g=\sigma^{2} a+\sigma^{2} d+\sigma^{2} i\right)$.

Se o objetivo for a exploração de híbridos, pode-se afirmar que a dominância e os efeitos epistáticos manifestados agiram desfavoravelmente aos interesses no 
melhoramento. Os valores positivos indicaram, no caso da heterose, que a média do caráter na geração $F_{1}$ foi maior que a média dos progenitores e no da epistasia, que a média de $\mathrm{F}_{2}$ observada foi maior do que a esperada.

As médias dos retrocruzamentos HV-12 x (HV-12 x 609) e HV-12 x (442 x HV12) (2,26 e 2,57) confirmaram os resultados obtidos por Daubeze et al. (1995), apresentando uma menor média de severidade da doença quando comparados as gerações $F_{2}$ (Tabela 10). É uma estratégia no melhoramento fazer só o retrocruzamento para o parental resistente, para aumentar a freqüência dos genes favoráveis de resistência ao oídio com suficiente variabilidade residual para posterior seleção quanto à qualidade de frutos.

O número de locos segregantes calculado confirmou os resultados obtidos por Shifriss et al. (1992), Daubeze et al. (1995) e Murthy \& Deshpande (1997). Para os cruzamentos HV-12 x 609 e \#124 x 609 existem no mínimo dois genes segregantes envolvidos na herança, enquanto para os cruzamentos 442 x HV-12 e 428 x HV-12 pelo menos três genes se manifestaram. No cruzamento Chilli x 609 os resultados calculados pela freqüência e pela fórmula de Burton (1951) diferiram, pelo cálculo das freqüências detectou-se no mínimo quatro genes segregantes, enquanto pela formula de Burton (1951), nove genes estariam governando a herança da resistência ao oídio. Nesse último caso, o número de genes estimado pela fórmula foi bem maior que o considerado pelas freqüências. Esse fato pode ter ocorrido pela baixa variância observada na geração $F_{2}$ $\left(\sigma^{2}=0,401\right)$ se comparada a dos progenitores $\left(\sigma_{\mathrm{P} 1}^{2}=0,255\right.$ e $\left.\sigma_{\mathrm{P} 2}^{2}=0,289\right)$. Esta pequena variância se deve ao grande número de plantas com nota 5 (610 plantas). Pode-se concluir com isso que os locos das linhagens progenitoras Chilli e 609 são mais divergentes do que o dos progenitores dos demais cruzamentos e que a herança da resistência ao oídio em $C$. annuum é poligênica e governada por pelo menos quatro pares de genes (Tabelas 9 e 10).

A esse respeito, sabe-se que heranças poligênicas geralmente demandam maior número de gerações de seleção para obtenção de homozigose, porém essas resistências são duráveis e mais difíceis de serem superadas pelo surgimento de raças mais patogênicas (Van der Plank, 1968). 
Sabe-se que quanto maior for o número de genes maior será a segregação e sua recombinação gênica na geração $F_{2}$ a ser explorada pelo melhorista. Os valores de herdabilidade foram altos, acima de $40 \%$, evidenciando uma boa possibilidade de ganho seletivo. Quanto maior for a herdabilidade, menos afetado pelas condições ambientais será o caráter. A população segregante em $\mathrm{F}_{2}$ do cruzamento 428 x HV-12 apresentou o maior grau de herdabilidade, 76,54\% enquanto que o cruzamento $442 \times \mathrm{xV}-12$ apresentou o menor, 54,96\%. Os ganhos de seleção estimados para as gerações $F_{3}$, apesar de superestimados também foram altos, evidenciando uma perspectiva favorável de progresso no programa de melhoramento para resistência ao oídio. Os maiores ganhos foram obtidos nos cruzamentos que apresentaram na geração $F_{2}$ maior média, ou mais suscetíveis. Esperaria-se um ganho de 35,2\% para Chilli x 609 e de 34,8\% para a geração $\mathrm{F}_{3}$ do cruzamento \#124 x 609, 34,8\% (Tabela 10). 
Tabela 9. Número de plantas em cada classe, de acordo com a escala de notas para resistência a Leveillula taurica sob condições de casa de vegetação. C. annuum. 2002

\begin{tabular}{|c|c|c|c|c|c|c|}
\hline \multicolumn{2}{|c|}{ Gerações ${ }^{1}$} & $\begin{array}{c}\text { R } \\
\text { Nota } 1 \\
\end{array}$ & $\begin{array}{c}\text { MR } \\
\text { Nota } 2 \\
\end{array}$ & $\begin{array}{c}\text { MS } \\
\text { Nota } 3 \\
\end{array}$ & $\begin{array}{c}\text { S } \\
\text { Nota } 4 \\
\end{array}$ & $\begin{array}{c}\text { AS } \\
\text { Nota } 5 \\
\end{array}$ \\
\hline & $\mathrm{PR}^{\bullet}$ & 9 & 0 & 0 & 0 & 0 \\
\hline \multirow[t]{2}{*}{$\mathrm{HV}-12$} & $\mathrm{PR}^{\bullet \bullet}$ & 40 & 0 & 0 & 0 & 0 \\
\hline & $\mathrm{PR}^{\bullet}$ & 0 & 9 & 0 & 0 & 0 \\
\hline \multirow[t]{2}{*}{ Chilli } & $\mathrm{PR}^{\bullet \bullet}$ & 22 & 23 & 0 & 0 & 0 \\
\hline & $\mathrm{PR}^{\bullet}$ & 0 & 9 & 0 & 0 & 0 \\
\hline \multirow[t]{2}{*}{ \#124 } & $\mathrm{PR}^{\bullet \bullet}$ & 17 & 23 & 0 & 0 & 0 \\
\hline & $\mathrm{PS}^{\bullet}$ & 0 & 0 & 0 & 0 & 9 \\
\hline \multirow[t]{2}{*}{609} & $\mathrm{PS}^{\bullet \bullet}$ & 0 & 0 & 1 & 12 & 26 \\
\hline & $\mathrm{PS}^{\bullet}$ & 0 & 0 & 0 & 0 & 9 \\
\hline \multirow[t]{2}{*}{442} & $\mathrm{PS}^{\bullet \bullet}$ & 0 & 0 & 7 & 9 & 36 \\
\hline & $\mathrm{PS}^{\bullet}$ & 0 & 0 & 0 & 0 & 9 \\
\hline \multirow[t]{2}{*}{428} & $\mathrm{PS}^{\bullet \bullet}$ & 0 & 0 & 0 & 15 & 22 \\
\hline & $\mathrm{TS}^{\bullet}$ & 0 & 0 & 0 & 0 & 9 \\
\hline \multirow[t]{2}{*}{ Magali R } & $\mathrm{TS}^{\bullet \bullet}$ & 0 & 0 & 0 & 0 & 45 \\
\hline & $\mathrm{TS}^{\bullet}$ & 0 & 0 & 0 & 0 & 9 \\
\hline \multirow[t]{2}{*}{ Margarita } & $\mathrm{TS}^{\bullet \bullet}$ & 0 & 0 & 0 & 0 & 45 \\
\hline & $\mathrm{F}_{1}^{\bullet}$ & 0 & 0 & 9 & 0 & 0 \\
\hline \multirow[t]{4}{*}{ HV-12 x 609} & $\mathrm{~F}_{1}^{\bullet \bullet}$ & 0 & 25 & 36 & 6 & 5 \\
\hline & $\mathrm{F}_{2} \bullet \bullet$ & 40 & 190 & 204 & 64 & 91 \\
\hline & $\mathrm{RC} \mathrm{PR}^{\bullet \bullet \bullet}$ & 55 & 63 & 62 & 14 & 6 \\
\hline & $\mathrm{F}_{1}^{\bullet}$ & 0 & 0 & 5 & 4 & 0 \\
\hline \multirow[t]{4}{*}{$442 \times \mathrm{HV}-12$} & $\mathrm{~F}_{1}^{\bullet \bullet}$ & 0 & 21 & 27 & 13 & 4 \\
\hline & $\mathrm{F}_{2} \bullet \bullet$ & 25 & 249 & 280 & 40 & 106 \\
\hline & $\mathrm{RC} \mathrm{PR}^{\bullet \bullet \bullet}$ & 35 & 51 & 86 & 20 & 8 \\
\hline & $\mathrm{F}_{1}^{\bullet}$ & 0 & 0 & 6 & 1 & 2 \\
\hline \multirow[t]{3}{*}{$428 \times \mathrm{HV}-12$} & $\mathrm{~F}_{1}^{\bullet \bullet}$ & 0 & 0 & 16 & 5 & 5 \\
\hline & $\mathrm{F}_{2}^{\bullet \bullet}$ & 18 & 172 & 149 & 75 & 219 \\
\hline & $\mathrm{F}_{1}^{\bullet}$ & 0 & 0 & 0 & 4 & 5 \\
\hline \multirow[t]{3}{*}{ Chilli x 609} & $\mathrm{~F}_{1}^{\bullet \bullet}$ & 0 & 0 & 0 & 1 & 24 \\
\hline & $\mathrm{F}_{2}^{\bullet \bullet}$ & 0 & 8 & 52 & 65 & 610 \\
\hline & $\mathrm{F}_{1}^{\bullet}$ & 0 & 0 & 0 & 8 & 9 \\
\hline \multirow[t]{2}{*}{ \# 124 x 609} & $\mathrm{~F}_{1}^{\bullet \bullet}$ & 0 & 0 & 3 & 13 & 7 \\
\hline & $\mathrm{F}_{2}^{\bullet \bullet}$ & 1 & 99 & 306 & 176 & 511 \\
\hline
\end{tabular}

- Resultados obtidos em fevereiro de 2002 (primeira avaliação) - na obtenção da geração $\mathrm{F}_{1}$.

• Resultados obtidos em setembro de 2002 (segunda avaliação) - na obtenção da geração $F_{2}$.

-・ Resultados obtidos em fevereiro de 2003.

1. PR - Progenitor resistente, PS - progenitor suscetível, RC PR - retrocruzamento, TS Testemunha suscetível 
Tabela 10. Estimativas de médias de notas, variâncias, do número de locos segregantes e da herdabilidade $\left(\mathrm{h}^{2}\right)$, nas diferentes gerações de cinco cruzamentos e ganho de seleção esperado em $\mathrm{F}_{3}$ (Gs). C. annuum. 2002

\begin{tabular}{|c|c|c|c|c|c|c|c|c|}
\hline \multirow{2}{*}{\multicolumn{2}{|c|}{ Gerações $^{1}$}} & \multirow[b]{2}{*}{$\mathbf{n}$} & \multirow[b]{2}{*}{ Médias } & \multirow[b]{2}{*}{ Variâncias } & \multicolumn{2}{|c|}{$\mathrm{N}^{0}$ locos } & \multirow{2}{*}{$\begin{array}{c}\mathbf{h}^{2} \\
(\%)\end{array}$} & \multirow{2}{*}{$\begin{array}{l}\text { Gs } \\
(\%)\end{array}$} \\
\hline & & & & & Freq & Form. & & \\
\hline \multirow[t]{2}{*}{$\mathrm{HV}-12$} & $\mathrm{PR}^{\bullet}$ & 9 & 1,00 & 0,000 & & & & \\
\hline & $\mathrm{PR}^{\bullet \bullet}$ & 40 & 1,00 & 0,000 & & & & \\
\hline \multirow[t]{2}{*}{ Chilli } & $\mathrm{PR}^{\bullet}$ & 9 & 2,00 & 0,000 & & & & \\
\hline & $\mathrm{PR}^{\bullet \bullet}$ & 45 & 1,51 & 0,255 & & & & \\
\hline \multirow[t]{2}{*}{$\# 124$} & $\mathrm{PR}^{\bullet}$ & 9 & 2,00 & 0,000 & & & & \\
\hline & $\mathrm{PR}^{\bullet \bullet}$ & 40 & 1,57 & 0,250 & & & & \\
\hline \multirow[t]{2}{*}{609} & $\mathrm{PS}^{\bullet}$ & 9 & 5,00 & 0,000 & & & & \\
\hline & $\mathrm{PS}^{\bullet \bullet}$ & 39 & 4,64 & 0,289 & & & & \\
\hline \multirow[t]{2}{*}{442} & $\mathrm{PS} \bullet$ & 9 & 5,00 & 0,000 & & & & \\
\hline & $\mathrm{PS} \bullet \bullet$ & 52 & 4,56 & 0,526 & & & & \\
\hline \multirow[t]{2}{*}{428} & $\mathrm{PS}^{\bullet}$ & 9 & 5,00 & 0,000 & & & & \\
\hline & $\mathrm{PS} \bullet \bullet$ & 37 & 4,60 & 0,248 & & & & \\
\hline \multirow[t]{2}{*}{ Magali R } & $\mathrm{TS}^{\bullet}$ & 9 & 5,00 & 0,000 & & & & \\
\hline & $\mathrm{TS}^{\bullet \bullet}$ & 45 & 5,00 & 0,000 & & & & \\
\hline \multirow[t]{2}{*}{ Margarita } & $\mathrm{TS}^{\bullet}$ & 9 & 5,00 & 0,000 & & & & \\
\hline & $\mathrm{TS}^{\bullet \bullet}$ & 45 & 5,00 & 0,000 & & & & \\
\hline \multirow[t]{4}{*}{ HV-12 x 609} & $\mathrm{~F}_{1}^{\bullet}$ & 9 & 3,00 & 0,000 & & & & \\
\hline & $\mathrm{F}_{1}^{\bullet \bullet}$ & 72 & 2,87 & 0,702 & & & & \\
\hline & $\mathrm{F}_{2} \bullet \bullet$ & 589 & 2,96 & 1,320 & $\geq 2$ & 2 & 67,95 & $-26,0$ \\
\hline & $\mathrm{RCPR}^{\bullet \bullet \bullet}$ & 200 & 2,26 & 1,073 & & & & \\
\hline \multirow[t]{4}{*}{$442 \times \mathrm{HV}-12$} & $\mathrm{~F}_{1}^{\bullet}$ & 9 & 3,44 & 0,278 & & & & \\
\hline & $\mathrm{F}_{1}^{\bullet \bullet}$ & 65 & 3,00 & 0,781 & & & & \\
\hline & $\mathrm{F}_{2} \bullet \bullet$ & 700 & 2,93 & 1,159 & $\geq 3$ & 3 & 54,96 & $-19,1^{\wedge}$ \\
\hline & $\mathrm{RCPR}^{\bullet \bullet \bullet}$ & 200 & 2,57 & 1,040 & & & & \\
\hline \multirow[t]{3}{*}{$428 \times \mathrm{HV}-12$} & $\mathrm{~F}_{1}^{\bullet}$ & 9 & 3,55 & 0,778 & & & & \\
\hline & $\mathrm{F}_{1} \bullet \bullet$ & 26 & 3,58 & 0,654 & & & & \\
\hline & $\mathrm{F}_{2} \bullet \bullet$ & 633 & 3,48 & 1,658 & $\geq 3$ & 2 & 76,54 & $-34,8^{\wedge}$ \\
\hline \multirow[t]{3}{*}{ Chilli x 609} & $\mathrm{~F}_{1}^{\bullet}$ & 9 & 4,55 & 0,278 & & & & \\
\hline & $\mathrm{F}_{1}^{\bullet \bullet}$ & 25 & 4,96 & 0,040 & & & & \\
\hline & $\mathrm{F}_{2}^{\bullet \bullet}$ & 735 & 4,74 & 0,401 & $\geq 4$ & 9 & 61,10 & $-35,2^{\boldsymbol{\Lambda}}$ \\
\hline \multirow[t]{3}{*}{$\# 124 \times 609$} & $\mathrm{~F}_{1}^{\bullet}$ & 9 & 4,11 & 0,111 & & & & \\
\hline & $\mathrm{F}_{1}^{\bullet \bullet}$ & 23 & 4,17 & 0,423 & & & & \\
\hline & $\mathrm{F}_{2} \bullet \bullet$ & 1093 & 4,00 & 1,119 & $\geq 2$ & 2 & 69,08 & $-34,8^{\wedge}$ \\
\hline
\end{tabular}

-Resultados obtidos em fevereiro de 2002 (primeira avaliação) - na obtenção da geração $\mathrm{F}_{1}$.

• Resultados obtidos em setembro de 2002 (segunda avaliação) - na obtenção da geração $F_{2}$.

- Resultados obtidos em fevereiro de 2003.

$\Delta$ Ganho de seleção superestimado, calculado em função de $\mathrm{h}^{2}$ no sentido amplo.

1. $\quad$ PR - Progenitor resistente, PS - progenitor suscetível, RC PR - retrocruzamento, TS Testemunha suscetível 
Tabela 11. Estimativas dos valores da heterose ( $\mathrm{H}$ e $\mathrm{H} \%)$ e de efeitos da epistasia (C) com significância pelo teste t. C. annuum. 2002

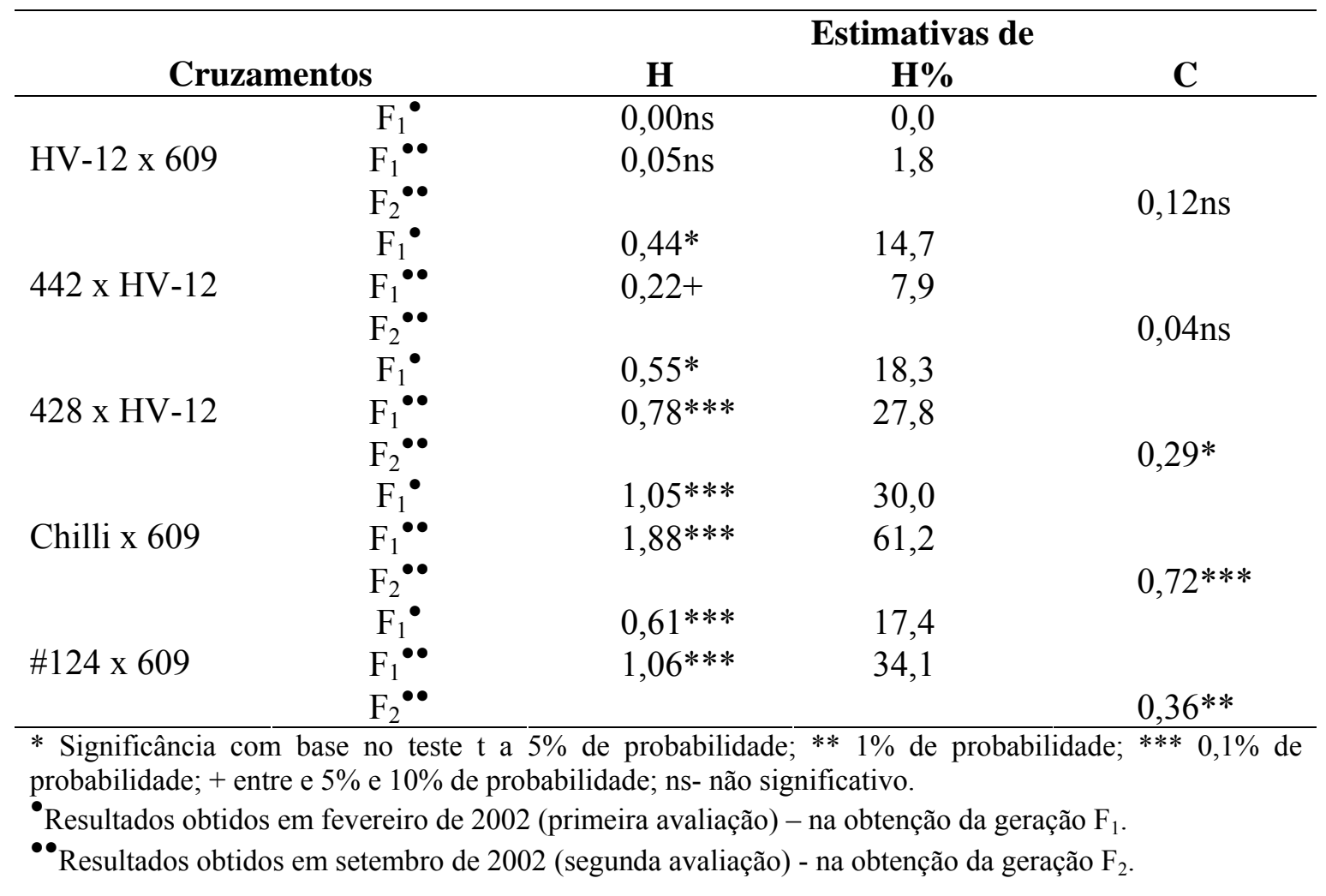



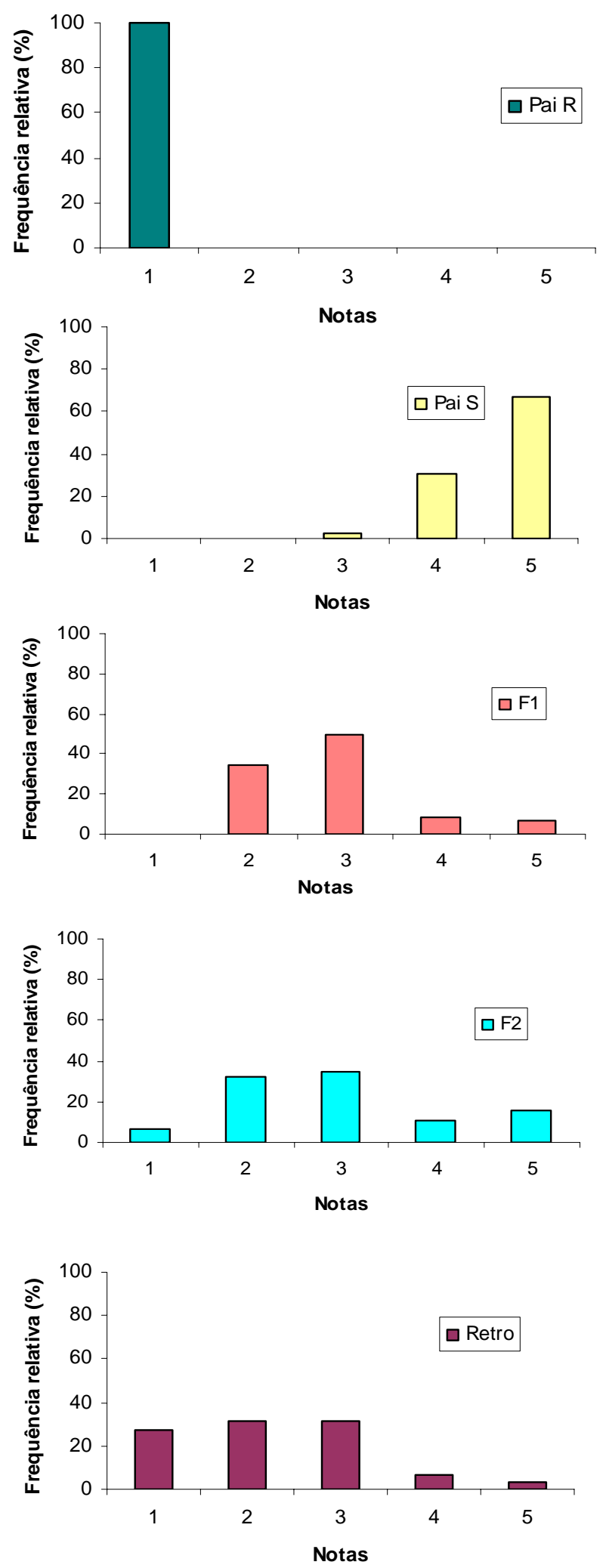

Figura 2 - Histograma de distribuição de freqüência de plantas em cada classe de notas nas gerações $\mathrm{P}_{\mathrm{R}}, \mathrm{P}_{\mathrm{S}}, \mathrm{F}_{1}, \mathrm{~F}_{2}, \mathrm{R}_{\mathrm{CR}}$ para o cruzamento HV-12 x 609. Capsicum annuum L. 2002 

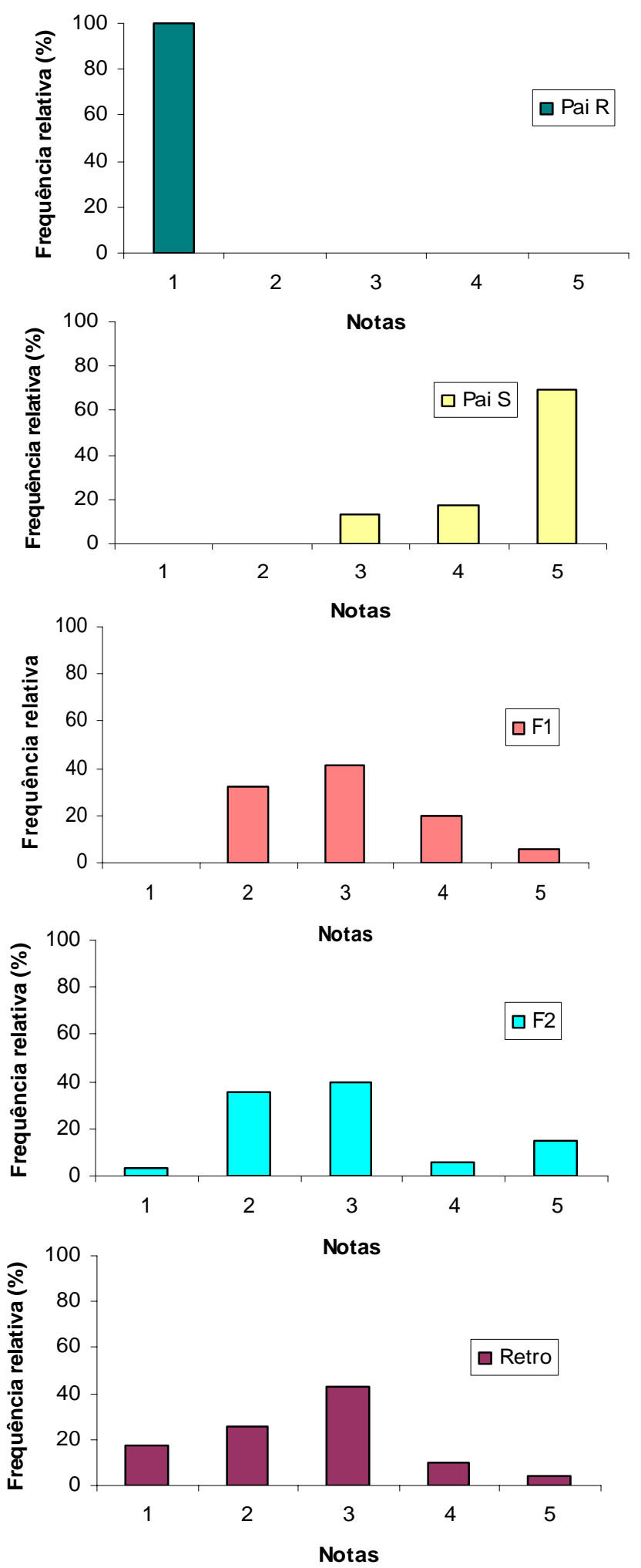

Figura 3 - Histograma de distribuição de freqüência de plantas em cada classe de notas nas gerações $\mathrm{P}_{\mathrm{R}}, \mathrm{P}_{\mathrm{S}}, \mathrm{F}_{1}, \mathrm{~F}_{2}, \mathrm{R}_{\mathrm{CR}}$ para o cruzamento $442 \times \mathrm{HV}-12$. Capsicum annuum L. 2002 

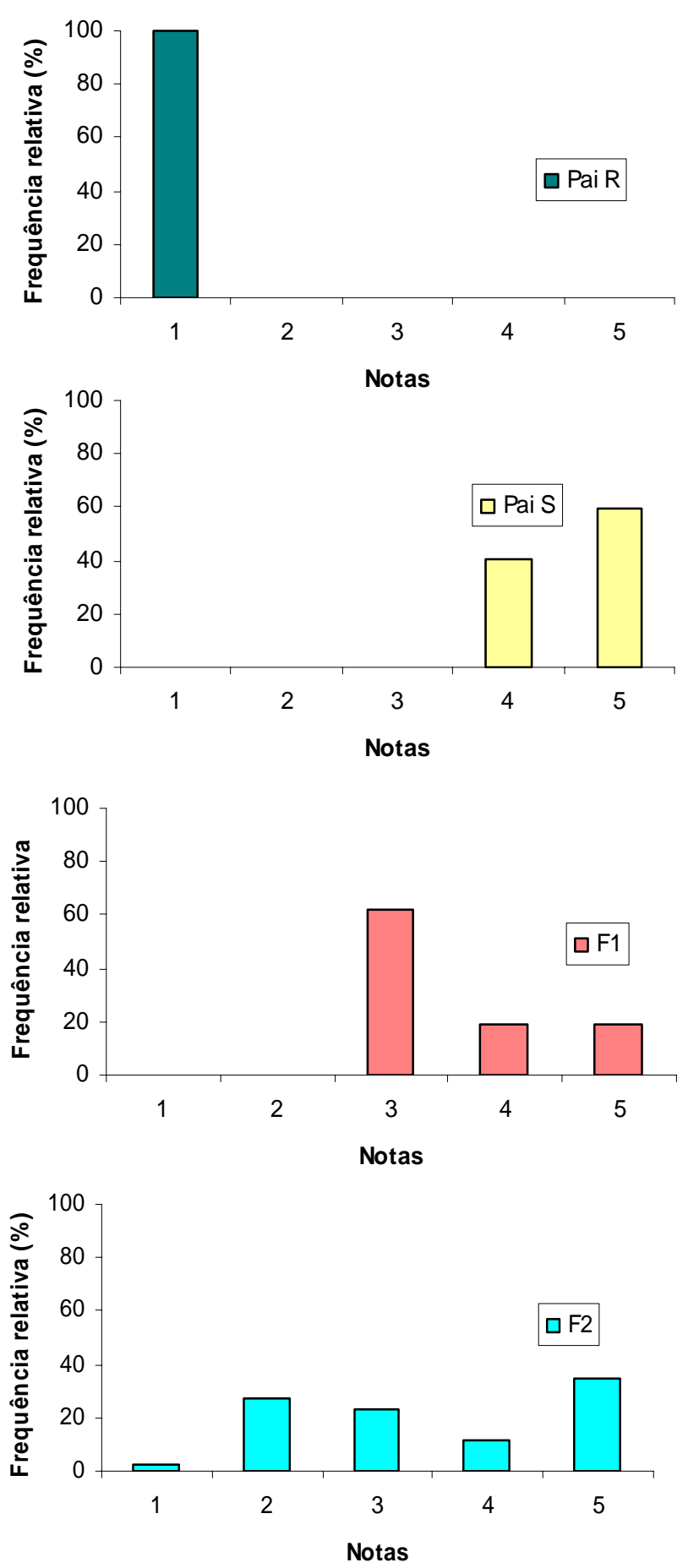

Figura 4 - Histograma de distribuição de freqüência de plantas em cada classe de notas nas gerações $\mathrm{P}_{\mathrm{R}}, \mathrm{P}_{\mathrm{S}}, \mathrm{F}_{1}$ e $\mathrm{F}_{2}$ para o cruzamento $428 \times \mathrm{HV}-12$. Capsicum annuum L. 2002 

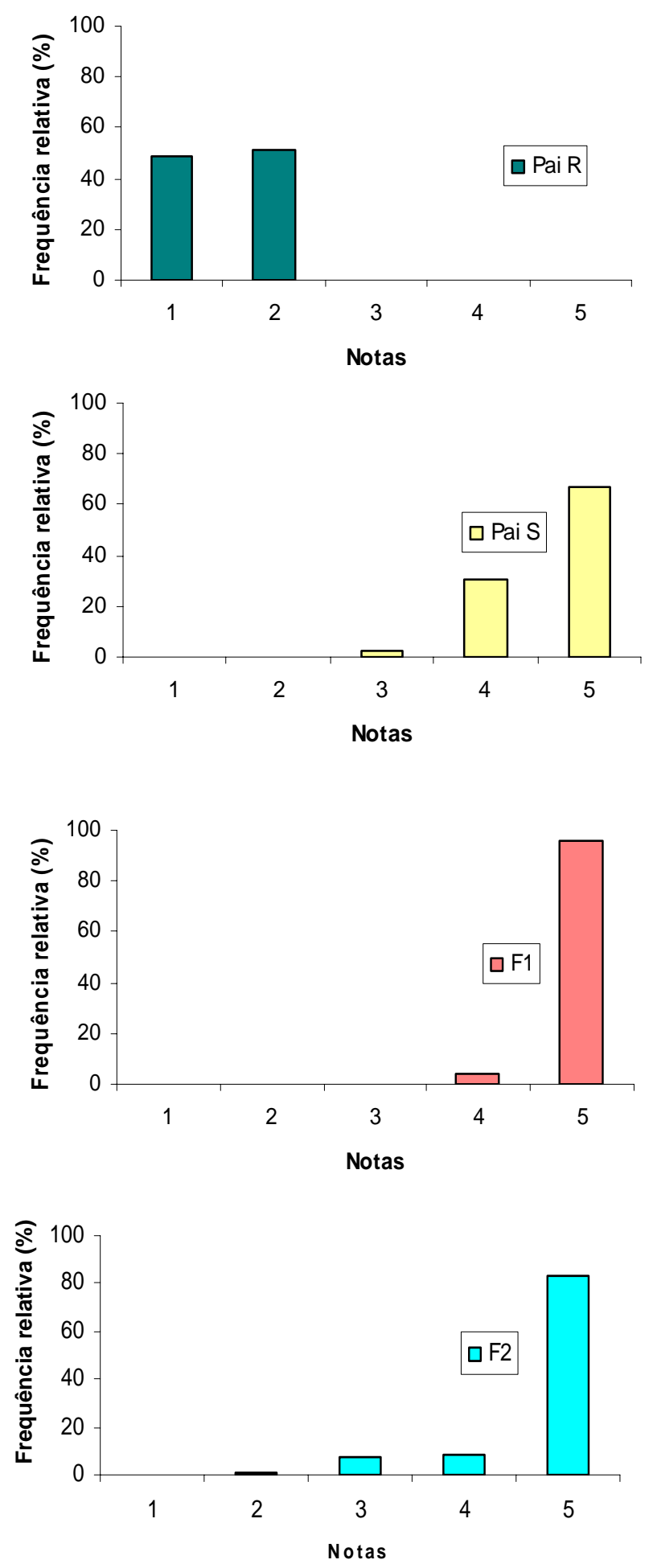

Figura 5 - Histograma de distribuição de freqüência de plantas em cada classe de notas nas gerações $\mathrm{P}_{\mathrm{R}}, \mathrm{P}_{\mathrm{S}}, \mathrm{F}_{1}$ e $\mathrm{F}_{2}$ para o cruzamento Chilli x 609. Capsicum annuum L. 2002 

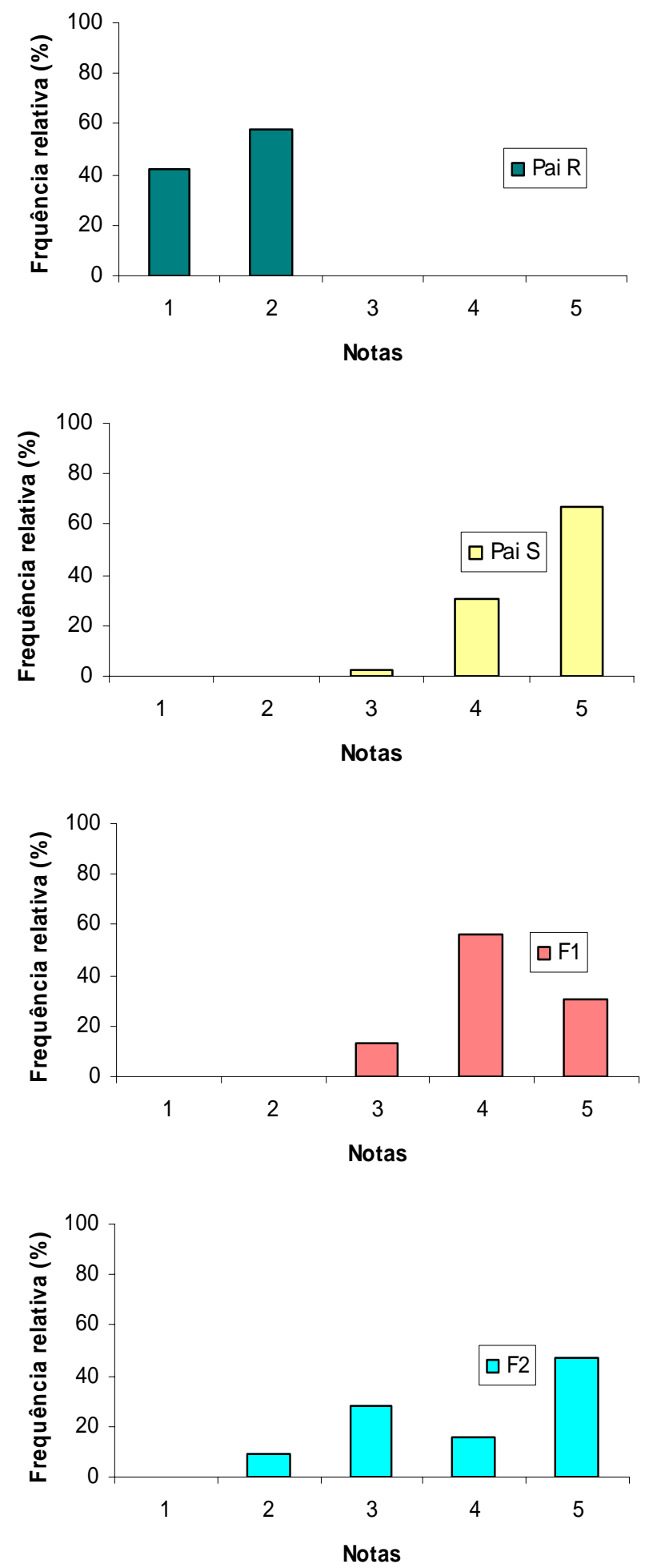

Figura 6 - Histograma de distribuição de freqüência de plantas em cada classe de notas nas gerações $\mathrm{P}_{\mathrm{R}}, \mathrm{P}_{\mathrm{S}}, \mathrm{F}_{1}$ e $\mathrm{F}_{2}$ para o cruzamento \#124 x 609. Capsicum annuum L. 2002 


\subsection{Avaliação da qualidade dos frutos}

O progenitor HV-12 apesar de ser uma excelente fonte de resistência ao oídio, tem frutos do tipo cônico longo, com espessura de polpa fina $(3 \mathrm{~mm})$, sem valor comercial. Os progenitores suscetíveis 609,442 e 428 destacam-se pelo tipo de fruto quadrado, polpa grossa, característica desejada pelo mercado de pimentão. O progenitor 609 apresentou frutos tipo Yolo Wonder ou quadrado, padrão no mercado norte americano e europeu. Os progenitores 428 e 442 apresentam ambos frutos tipo retangular médio, com polpa grossa de até $7 \mathrm{~mm}$ (Figuras, 7, 8 e 9).

Observou-se que na geração $F_{1}$ os frutos dos cruzamentos HV-12 x 609, 442 x HV-12 e 428 x HV-12 foram 100\% tipo retangular médio, mostrando ser um caráter de alta herdabilidade, sem efeito ambiental, onde o fenótipo representa o genótipo. As respectivas gerações $F_{2}$ derivadas dos cruzamentos com HV-12, apresentaram também as maiores proporções de frutos tipo retangular médio com $56,5 \%, 47,7 \%$ e $52,2 \%$ do total para cada cruzamento respectivamente. As segundas maiores proporções foram tipo cônico médio com $20 \%$ e 19,4\% para os cruzamentos HV-12 x 609 e 442 x 609 e retangular longo para $428 \times \mathrm{HV}-12$ com 22,1\%. Nos retrocruzamentos é interessante notar que quando se comparam os frutos dessa geração com a $F_{2}$, a proporção do tipo retangular médio reduziu de 56,5\% para 42,0\% no HV-12 x (HV-12 x 609) e de 47,7\% para $20,3 \%$ no HV-12 x (442 x HV-12) e aumentou em ambos o tipo do progenitor recorrente HV-12, cônico longo, de 9,4 para 14,8 e 9,7 para 25,4\% respectivamente (Figuras, 7, 8 e 9). Nesta geração não segregaram plantas com frutos do tipo Yolo Wonder, ou quadrados.

Formato de fruto de pimentão determina importantes segmentos varietais no mercado mundial. O segmento de pimentão quadrado é importante nos EUA, e norte da Europa, Japão e muitos países da América do Sul inclusive na região Nordeste do Brasil. $\mathrm{Na}$ Europa, em países como a França, o tipo retangular médio é bastante aceito. Existe ainda demanda do tipo de frutos retangular longo na Espanha e Itália principalmente no cultivo protegido. Os pimentões cônicos tanto longos tipo Italiano como curtos tipo Morrones, tem seus mercados específicos na Europa e na Ásia. No Brasil até o presente momento a preferência é para o tipo Casca Dura semi-cônico longo padronizado pelo 
híbrido Magali-R e retangular médio e longo para o cultivo de pimentões de estufas. No nordeste brasileiro a preferência é para o tipo quadrado.

Portanto, ampla variabilidade de tipos e formatos de frutos de pimentão resistentes ao oídio, será muito interessante no desenvolvimento de variedades e híbridos tanto para o mercado brasileiro como internacional. 

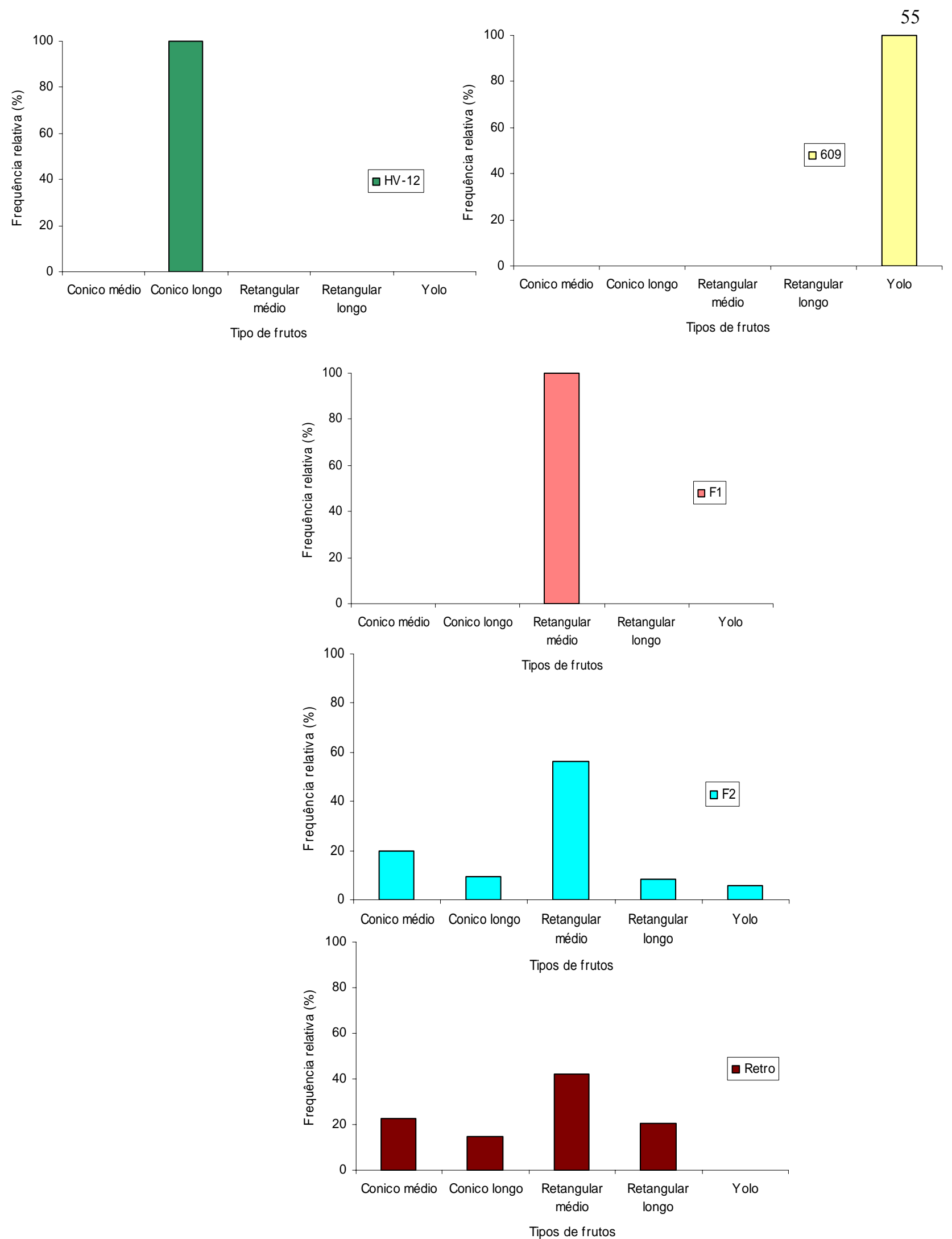

Figura 7 - Histograma de distribuição de freqüência do tipo de frutos nas gerações $P_{R}$, $\mathrm{P}_{\mathrm{S}}, \mathrm{F}_{1}, \mathrm{~F}_{2}, \mathrm{R}_{\mathrm{CR}}$ para o cruzamento HV-12 x 609. C. annuum. 2002 

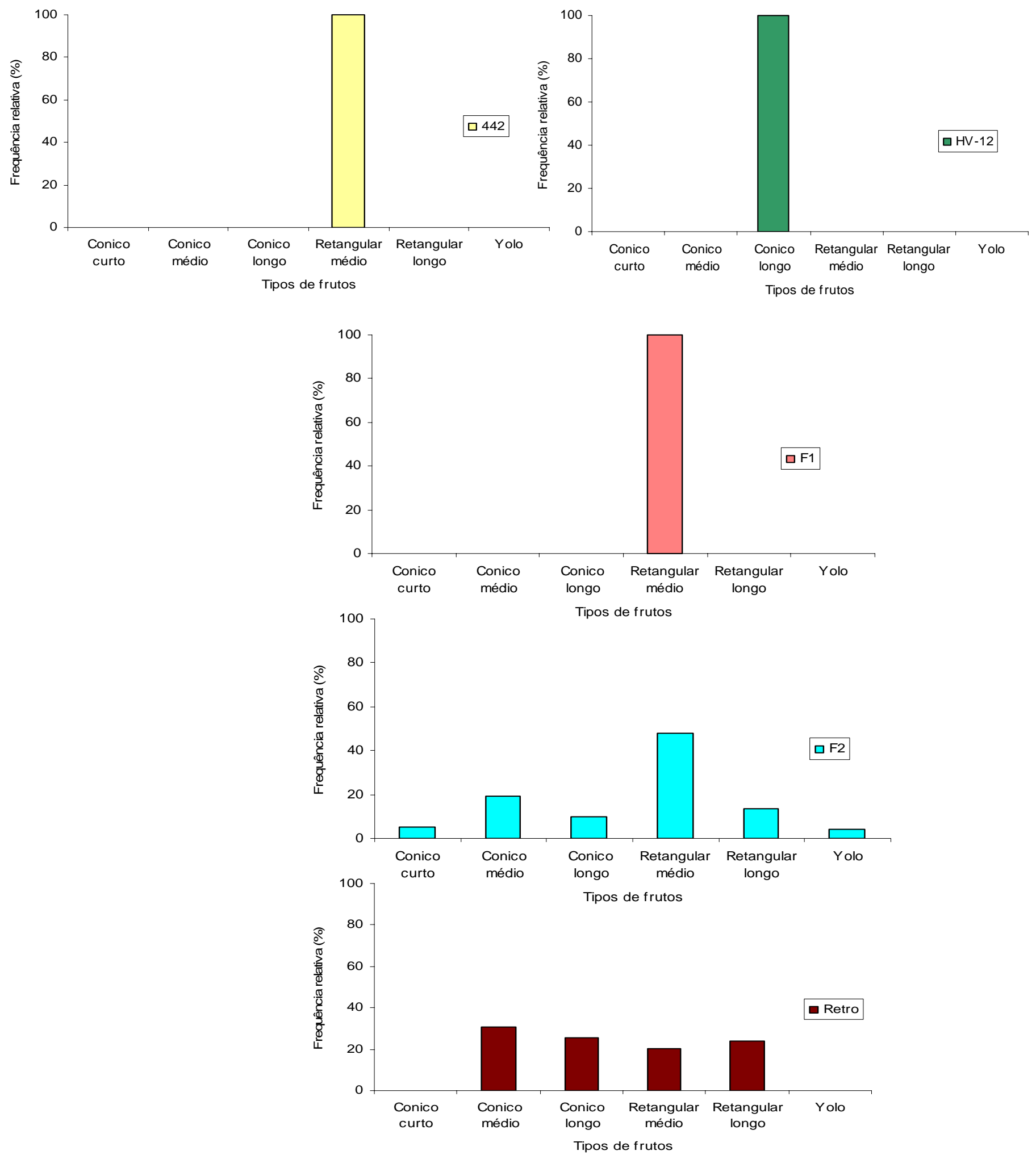

Figura 8 - Histograma de distribuição de freqüência do tipo de frutos nas gerações $\mathrm{P}_{\mathrm{R}}$, $\mathrm{P}_{\mathrm{S}}, \mathrm{F}_{1}, \mathrm{~F}_{2}, \mathrm{R}_{\mathrm{CR}}$ para o cruzamento $442 \times \mathrm{HV}-12$. C. annuum. 2002 

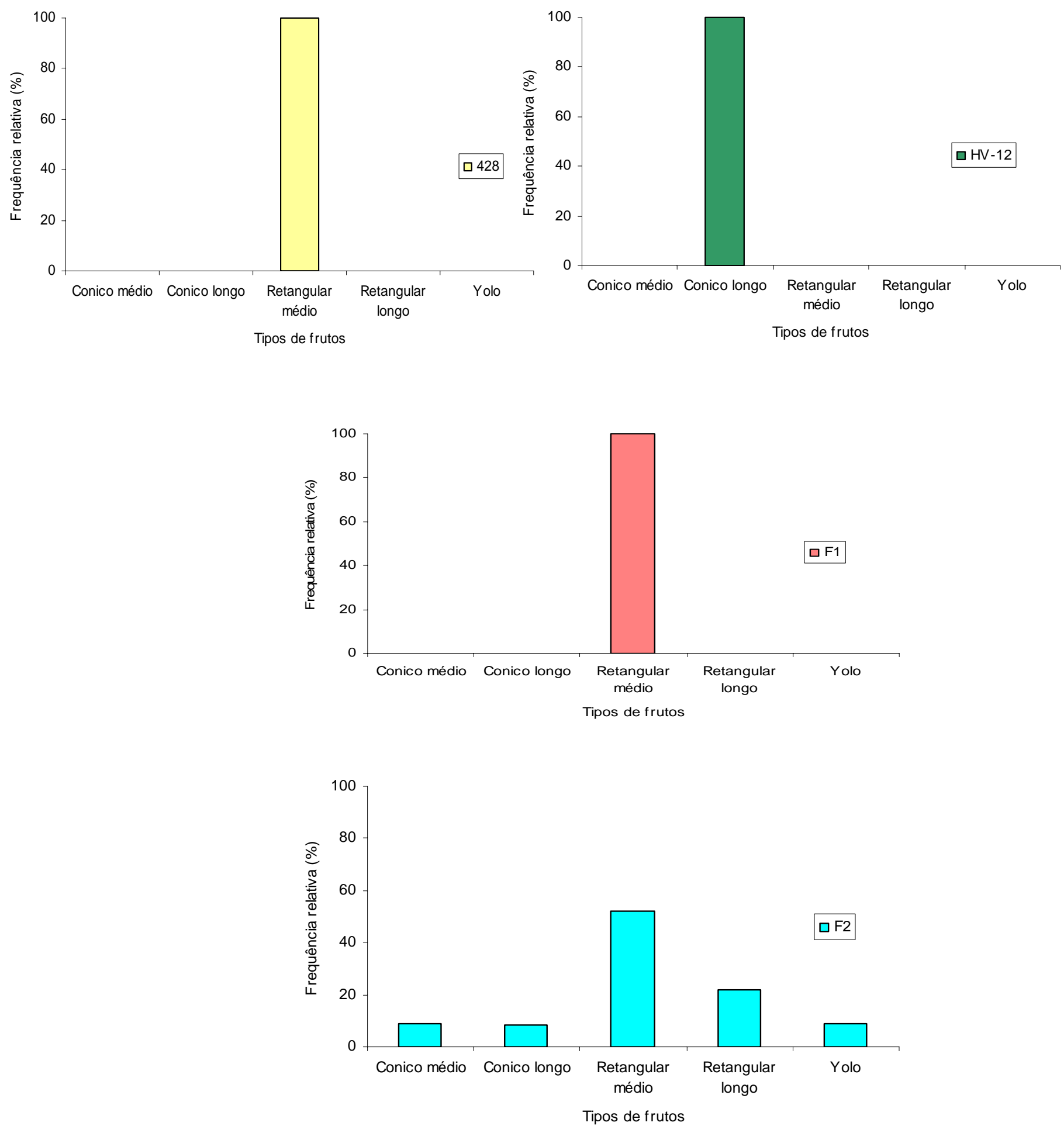

Figura 9 - Histograma de distribuição de freqüência do tipo de frutos das gerações $\mathrm{P}_{\mathrm{R}}$, $\mathrm{P}_{\mathrm{S}}, \mathrm{F}_{1}$ e $\mathrm{F}_{2}$ para o cruzamento 428 x HV-12. C. annuum. 2002 


\subsection{Seleção}

As reações dos progenitores, tanto resistentes HV-12 como suscetíveis 609, 442 e 428 e das testemunhas Magali R e Margarita mostraram que apesar das avaliações das gerações $F_{2}$ e $F_{3}$ terem sido feitas em épocas diferentes, os resultados podem ser comparados. Pela tabela 12, observa-se que esses progenitores e testemunhas mantiveram médias similares em ambas as avaliações, demonstrando que as pressões de inóculo de oídio utilizadas foram similares nas duas avaliações.

Os cruzamentos HV-12 x 609 e 442 x HV-12 confirmaram na geração $F_{3}$ a eficiência seletiva para resistência ao oídio feita na geração $F_{2}$. Apresentaram o maior número de plantas resistentes (nota 1 e 2 ) na geração $F_{3}$, sendo de $86 \%$ para $\mathrm{HV}-12$ x 609 e $78 \%$ para 442 x HV-12.

A seleção efetuada para resistência ao oídio foi muito eficiente, com resultados promissores. A média esperada sem seleção para a população $F_{3}$ do cruzamento $\mathrm{HV}-12$ x 609 seria de 2,89 e com a seleção foi de 1,59 tendo, portanto, um progresso real em média observado de 1,30 ou $45 \%$ da geração $F_{2}$ para a $F_{3}$. Para a geração $F_{3}$ do cruzamento 442 x HV-12, a média esperada sem seleção seria de 2,85, porém com a seleção foi de 1,80 , tendo um progresso em média de 1,05 ou 36,8\%. Finalmente para a geração $F_{3}$ do híbrido original 428 x HV-12 a média esperada sem seleção seria de 3,14, praticando-se a seleção passou a 2,05, obtendo um progresso de 1,09 em média ou de $34,7 \%$ (Tabela 12). As altas porcentagens no progresso de seleção confirmam a alta herdabilidade do caráter já descrita.

As melhores progênies $F_{3}$, mais uniformes e homozigóticas para resistência seriam avançadas e para obtenção das próximas gerações e a partir da geração $\mathrm{F}_{4}$ e $\mathrm{F}_{5}$ testadas para suas capacidades de combinação visando-se o desenvolvimento de híbridos de pimentão resistente ao oídio.

Convêm destacar com relação à triagem de virose que de um total de 126 progênies $\mathrm{F}_{3}$ no cruzamento $\mathrm{HV}-12$ x 609, 58 progênies estavam em homozigose para resistência ao PVY/PeMV, 50 estavam heterozigóticas e 23 homozigoticas para suscetibilidade. Para o cruzamento 442 x HV-12 esta proporção foi de 53 progênies homozigoticas resistentes, 52 heterozigoticas e 26 homozigoticas suscetíveis. Para 428 x 
HV-12, das 50 progênies avaliadas cerca de 15 apresentaram-se homozigóticas resistentes, 22 heterozogoticas e 13 homozigoticas suscetíveis.

Tabela 12. Número de plantas, médias observadas, médias esperadas sem seleção e progresso observado (\%) na geração $\mathrm{F}_{3}$. C. annuum. 2003

\begin{tabular}{|c|c|c|c|c|c|c|c|c|c|}
\hline \multirow{2}{*}{\multicolumn{2}{|c|}{ Gerações $^{1}$}} & \multirow{2}{*}{$\begin{array}{c}\mathbf{R} \\
\mathbf{1}\end{array}$} & \multirow{2}{*}{$\frac{\text { MR }}{2}$} & \multirow{2}{*}{$\begin{array}{c}\text { MS } \\
3\end{array}$} & \multirow{2}{*}{$\begin{array}{l}S \\
4\end{array}$} & \multirow{2}{*}{$\begin{array}{c}\text { AS } \\
5\end{array}$} & \multirow{2}{*}{$\begin{array}{l}\text { Médias } \\
\text { observ. }\end{array}$} & \multicolumn{2}{|c|}{ Médias e Progresso } \\
\hline & & & & & & & & s/ seleção & c/ seleção \\
\hline \multirow[t]{2}{*}{$\mathrm{HV}-12$} & $\mathrm{PR}^{\bullet \bullet}$ & 40 & 0 & 0 & 0 & 0 & 1,00 & & \\
\hline & $\mathrm{PR}^{\bullet \bullet \bullet \bullet ~}$ & 40 & 0 & 0 & 0 & 0 & 1,00 & & \\
\hline \multirow[t]{2}{*}{609} & $\mathrm{PS}^{\bullet \bullet}$ & 0 & 0 & 0 & 13 & 26 & 4,64 & & \\
\hline & $P S^{\bullet \bullet \bullet}$ & 0 & 0 & 1 & 12 & 26 & 4,67 & & \\
\hline \multirow[t]{2}{*}{442} & $\mathrm{PS}^{\bullet \bullet}$ & 0 & 0 & 7 & 8 & 36 & 4,56 & & \\
\hline & $P S^{\bullet \bullet \bullet}$ & 0 & 0 & 7 & 9 & 36 & 4,51 & & \\
\hline \multirow[t]{2}{*}{428} & $\mathrm{PS}^{\bullet \bullet}$ & 0 & 0 & 0 & 15 & 27 & 4,60 & & \\
\hline & $\mathrm{PS}^{\bullet \bullet \bullet}$ & 0 & 0 & 0 & 15 & 22 & 4,64 & & \\
\hline \multirow[t]{2}{*}{ Magali R } & $\mathrm{TS}^{\bullet \bullet}$ & 0 & 0 & 0 & 0 & 40 & 5,00 & & \\
\hline & $\mathrm{TS}^{\bullet \bullet \bullet \bullet}$ & 0 & 0 & 0 & 0 & 45 & 5,00 & & \\
\hline \multirow[t]{2}{*}{ Margarita } & $\mathrm{TS}^{\bullet \bullet}$ & 0 & 0 & 0 & 0 & 40 & 5,00 & & \\
\hline & $\mathrm{TS}^{\bullet \bullet \bullet \bullet}$ & 0 & 0 & 0 & 0 & 45 & 5,00 & & \\
\hline \multirow[t]{2}{*}{ HV-12 x 609} & $\mathrm{~F}_{2}^{\bullet \bullet}$ & 40 & 190 & 204 & 64 & 91 & 2,96 & & \\
\hline & $\mathrm{F}_{3} \bullet \bullet \bullet$ & 580 & 259 & 102 & 31 & 6 & 1,59 & 2,89 & $1,30(45,0 \%)$ \\
\hline \multirow[t]{2}{*}{$442 \times \mathrm{HV}-12$} & $\mathrm{~F}_{2}^{\bullet \bullet}$ & 25 & 249 & 280 & 40 & 106 & 2,93 & & \\
\hline & $\mathrm{F}_{3} \bullet \bullet \bullet$ & 266 & 183 & 103 & 13 & 7 & 1,80 & 2,85 & $1,05(36,8 \%)$ \\
\hline \multirow[t]{2}{*}{$428 \times \mathrm{HV}-12$} & $\mathrm{~F}_{2}^{\bullet \bullet}$ & 18 & 172 & 149 & 75 & 219 & 3,48 & & \\
\hline & $\mathrm{F}_{3} \bullet \bullet \bullet$ & 93 & 101 & 38 & 14 & 14 & 2,05 & 3,14 & $1,09(34,7 \%)$ \\
\hline
\end{tabular}

• Resultados obtidos em setembro de 2002 (segunda avaliação) - na obtenção da geração $\mathrm{F}_{2}$.

••• Resultados obtidos em maio de 2003 - na obtenção da geração $F_{3}$ após seleção em $F_{2}$.

1. $\quad$ PR - Progenitor resistente, PS - progenitor suscetível, TS - Testemunha suscetível.

\subsubsection{Reação de híbridos de pimenta resistentes ao oídio em C. annuum}

Os tipos de reações dos hospedeiros ao patógeno podem variar grandemente numa mesma espécie, dependendo do número de genes envolvidos. Van Der Plank (1968) relatou a existência de dois tipos de resistência, um controlado por poucos genes atuando contra raças específicas do patógeno e retardando o início de uma epidemia, denominado resistência vertical. O segundo tipo denominado resistência horizontal, é governado por muitos genes, cada qual apresentando pequeno efeito, que atuam contra várias raças do patógeno retardando e diminuindo o progresso da doença. A reação apresentada pela variedade HV-12 evidencia uma resistência tipo vertical, porém é possível a existência 
dos dois sistemas de resistência, o vertical e o horizontal, mas que um de seus genes, o principal e mais forte, de natureza oligogênica, determine a resistência. Por outro lado a resistência das fontes Chilli e \#124 mostrou-se tipo horizontal. A forte restrição e redução da esporulação, o pequeno número de lesões e o longo período de latência foram sintomas observados que destacaram e indicaram a natureza da resistência tipo horizontal.

Com base nesses tipos diferenciados de reações das fontes de resistência, HV-12, Chilli e \#124, têm-se a indicação de que os genótipos dos progenitores resistentes são diferentes.

Resistências do tipo horizontal são mais difíceis de serem superadas por eventuais surgimentos de raças mais patogênicas. No caso de ocorrência de algum tipo de mutação ou mecanismo que interfira na resistência, seriam necessários muitos genes de virulência do patógeno, interferindo em vários sítios de ação do hospedeiro. Outra característica típica da resistência horizontal é a grande influência que o ambiente pode ter sobre as reações, o que se confirmou nos progenitores Chilli e \#124, que tiveram suas reações variando entre as classes de notas, 1 e 2 (Tabela 13).

Os resultados obtidos das gerações $F_{1}$ e $F_{2}$ na segunda avaliação, confirmaram o que foi mencionado anteriormente sobre os sistemas genéticos dos progenitores resistentes. No cruzamento \#124 x HV-12, enquanto os progenitores apresentaram médias de 1,57 (\#124) e 1,00 (HV-12) as gerações $F_{1}$ e $F_{2}$ apresentaram médias de 2,71 e 2,88 respectivamente. O mesmo ocorreu cruzando a pimenta Chilli e HV-12 resistentes, com resultados ainda mais substanciais. A média da geração $F_{1}$ foi de 4,25, altamente suscetíveis enquanto a dos progenitores foi de 1,51 (Chilli) e 1,00 (HV-12). $\mathrm{Na}$ geração $\mathrm{F}_{2}$ houve grande segregação de reações ao oídio, com média de 3,05 (Tabela 14).

Quando foram testados os modelos aditivo-dominante e epistático, os contrastes envolvendo as médias das gerações $\mathrm{P}_{1}, \mathrm{P}_{2}, \mathrm{~F}_{1}$ e $\mathrm{F}_{2}$ para ambos os cruzamentos, foram significativos pelo teste $t$, mostrando que houve heterose em $F_{1}$ e efeitos epistáticos (Tabela 14). O fato de a heterose ter sido significativa indica que os progenitores são geneticamente diferentes e que há dominância pelo menos em alguns locos. 
Com base nos resultados pôde-se concluir que o sistema genético dos progenitores \#124, Chilli e HV-12 tem diferenças alélicas, ao menos em alguns locos, concordando com Murthy \& Deshpande (1997).

Para completa elucidação sobre o alelismo dessas fontes de resistência mais cruzamentos e gerações (retrocruzamentos) seriam necessários. Verificou-se que os sistemas genéticos são diferentes, porém não se poderia afirmar se seriam devidos a alelismo múltiplo ou diferentes locos (herança multifatorial). A hipótese que mais se enquadra é a segunda. Para melhor explicação tomou-se um exemplo conforme segue:

\begin{tabular}{lcc} 
Loco 1 & $\mathrm{S}$ & $\mathrm{s}$ \\
\multicolumn{1}{l}{ Loco 2 } & $\mathrm{T} \quad \mathrm{t}$ \\
$\mathrm{P}_{1}$ & ssTT (resistente) \\
$\mathrm{P}_{2}$ & $\mathrm{SStt}$ (resistente) \\
$\mathrm{F}_{1}$ & $\mathrm{SsTt}$ \\
$\mathrm{F}_{2}:$ &
\end{tabular}

\begin{tabular}{llllll}
\hline Genótipo & Frequência & Genótipo & frequência & genótipo & frequência \\
\hline Sstt & $1 / 16$ & SsTt & $2 / 16$ & ssTT & $1 / 16$ \\
Sstt & $2 / 16$ & SsTt & $4 / 16$ & SsTT & $2 / 16$ \\
SStt & $1 / 16$ & SSTt & $2 / 16$ & SsTT & $1 / 16$ \\
\hline
\end{tabular}

Nesse exemplo admitiram-se dois locos com dois alelos cada, com dominância no sentido da suscetibilidade. O progenitor 1 seria resistente por causa do gene ss e epistático pois TT não atuaria por causa de ss. O progenitor 2, seria resistente por causa de $t$ e epistático pois SS não atuaria diante de tt. $O F_{1}$ desse cruzamento teria a constituição genética SsTt, sendo mais suscetível que os progenitores resistentes, explicando assim nesta complementação gênica a suscetibilidade do $F_{1}$. Tomando-se o genótipo extremo recessivo (sstt) este teria que ter, no caso do cruzamento \#124 x HV- 
12, 58 plantas com esse genótipo (resistente, nota 1) e 51 plantas para Chilli x HV-12 e obteve-se 12 e 85 plantas respectivamente.

A primeira hipótese de alelismo múltiplo não explicaria de maneira alguma a epistasia apresentada nos cruzamentos e os tipos na geração $F_{2}$ teriam que ser mais próximos aos genótipos dos progenitores correspondentes, o que não ocorreu.

Tabela 13. Número de plantas em cada classe de acordo com a escala de notas para resistência a Leveillula taurica sob condições de casa de vegetação. C. annuum. 2002

\begin{tabular}{|c|c|c|c|c|c|c|}
\hline \multicolumn{2}{|c|}{ Gerações $^{1}$} & $\begin{array}{c}\text { R } \\
\text { Nota } 1 \\
\end{array}$ & $\begin{array}{c}\text { MR } \\
\text { Nota } 2 \\
\end{array}$ & $\begin{array}{c}\text { MS } \\
\text { Nota 3 }\end{array}$ & $\begin{array}{c}\text { S } \\
\text { Nota } 4 \\
\end{array}$ & $\begin{array}{c}\text { AS } \\
\text { Nota } 5 \\
\end{array}$ \\
\hline & $\mathrm{PR}^{\bullet}$ & 9 & 0 & 0 & 0 & 0 \\
\hline \multirow[t]{2}{*}{$\mathrm{HV}-12$} & $\mathrm{PR}^{\bullet \bullet}$ & 40 & 0 & 0 & 0 & 0 \\
\hline & $\mathrm{PR}^{\bullet}$ & 0 & 9 & 0 & 0 & 0 \\
\hline \multirow[t]{2}{*}{$\# 124$} & $\mathrm{PR}^{\bullet \bullet}$ & 17 & 23 & 0 & 0 & 0 \\
\hline & $\mathrm{PR}^{\bullet}$ & 0 & 6 & 3 & 0 & 0 \\
\hline \multirow[t]{2}{*}{ Chilli } & $\mathrm{PR}^{\bullet \bullet}$ & 22 & 23 & 0 & 0 & 0 \\
\hline & $\mathrm{TS}^{\bullet}$ & 0 & 0 & 0 & 0 & 9 \\
\hline \multirow[t]{2}{*}{ Magali R } & $\mathrm{TS}^{\bullet \bullet}$ & 0 & 0 & 0 & 0 & 45 \\
\hline & $\mathrm{TS}^{\bullet}$ & 0 & 0 & 0 & 0 & 9 \\
\hline \multirow[t]{2}{*}{ Margarita } & $\mathrm{TS}^{\bullet \bullet}$ & 0 & 0 & 0 & 0 & 45 \\
\hline & $\mathrm{F}_{1}^{\bullet}$ & 0 & 3 & 6 & 0 & 0 \\
\hline \multirow[t]{3}{*}{ \#124 x HV-12 } & $\mathrm{F}_{1}^{\bullet \bullet}$ & 0 & 20 & 31 & 4 & 0 \\
\hline & $\mathrm{F}_{2}^{\bullet \bullet}$ & 12 & 366 & 370 & 85 & 95 \\
\hline & $\mathrm{F}_{1}^{\bullet}$ & 0 & 0 & 0 & 6 & 3 \\
\hline \multirow{2}{*}{ Chilli x HV-12 } & $\mathrm{F}_{1}^{\bullet \bullet}$ & 0 & 0 & 13 & 20 & 28 \\
\hline & $\mathrm{F}_{2}^{\bullet \bullet}$ & 85 & 235 & 200 & 142 & 153 \\
\hline
\end{tabular}

- Resultados obtidos em fevereiro de 2002 (primeira avaliação) - na obtenção da geração $\mathrm{F}_{1}$.

•• Resultados obtidos em setembro de 2002 (segunda avaliação) - na obtenção da geração $\mathrm{F}_{2}$.

1. PR - Progenitor resistente, TS - Testemunha suscetível 
Tabela 14. Número total de plantas (n), estimativas de médias de notas, variâncias, dos valores da heterose $(\mathrm{H}$ e $\mathrm{H} \%)$ e epistasia (C) com significância pelo teste $\mathrm{t}$. C. annuum, 2002

\begin{tabular}{|c|c|c|c|c|c|c|c|}
\hline \multicolumn{2}{|c|}{ Gerações $^{1}$} & $\mathbf{n}$ & Médias & Variâncias & $\mathbf{H}$ & H\% & $\mathbf{C}$ \\
\hline & $\mathrm{PR}^{\bullet}$ & 9 & 1,00 & 0,000 & & & \\
\hline \multirow[t]{2}{*}{$\mathrm{HV}-12$} & $\mathrm{PR}^{\bullet \bullet}$ & 40 & 1,00 & 0,000 & & & \\
\hline & $\mathrm{PR}^{\bullet}$ & 9 & 2,00 & 0,000 & & & \\
\hline \multirow[t]{2}{*}{$\# 124$} & $\mathrm{PR}^{\bullet \bullet}$ & 40 & 1,57 & 0,250 & & & \\
\hline & $\mathrm{PR}^{\bullet}$ & 9 & 2,30 & 0,250 & & & \\
\hline \multirow[t]{2}{*}{ Chilli } & $\mathrm{PR}^{\bullet \bullet}$ & 45 & 1,51 & 0,255 & & & \\
\hline & $\mathrm{TS}^{\bullet}$ & 9 & 5,00 & 0,000 & & & \\
\hline \multirow[t]{2}{*}{ Magali R } & $\mathrm{TS}^{\bullet \bullet}$ & 45 & 5,00 & 0,000 & & & \\
\hline & $\mathrm{TS}^{\bullet}$ & 9 & 5,00 & 0,000 & & & \\
\hline \multirow[t]{2}{*}{ Margarita } & $\mathrm{TS}^{\bullet \bullet}$ & 45 & 5,00 & 0,000 & & & \\
\hline & $\mathrm{F}_{1}^{\bullet}$ & 9 & 2,67 & 0,250 & $1,17 * * *$ & 78,0 & \\
\hline \multirow[t]{3}{*}{ \#124 x HV-12 } & $\mathrm{F}_{1}^{\bullet \bullet}$ & 55 & 2,71 & 0,358 & $1,43 * * *$ & 111,7 & \\
\hline & $\mathrm{F}_{2}^{\bullet \bullet}$ & 928 & 2,88 & 0,933 & & & $0,88 * * *$ \\
\hline & $\mathrm{F}_{1}^{\bullet}$ & 9 & 4,3 & 0,250 & $2,65 * * *$ & 160,0 & \\
\hline \multirow[t]{2}{*}{ Chilli x HV-12 } & $\mathrm{F}_{1}^{\bullet \bullet}$ & 61 & 4,25 & 0,622 & $2,99 * * *$ & 238,2 & \\
\hline & $\mathrm{F}_{2}^{\bullet \bullet}$ & 815 & 3,05 & 1,630 & & & $0,30 * *$ \\
\hline
\end{tabular}

** Significância com base no teste t a $1 \%$ de probabilidade; *** $0,1 \%$ de probabilidade.

• Resultados obtidos em fevereiro de 2002 (primeira avaliação) - na obtenção da geração $\mathrm{F}_{1}$.

• Resultados obtidos em setembro de 2002 (segunda avaliação) - na obtenção da geração $\mathrm{F}_{2}$.

1. $\mathrm{PR}-$ Progenitor resistente, TS - Testemunha suscetível 

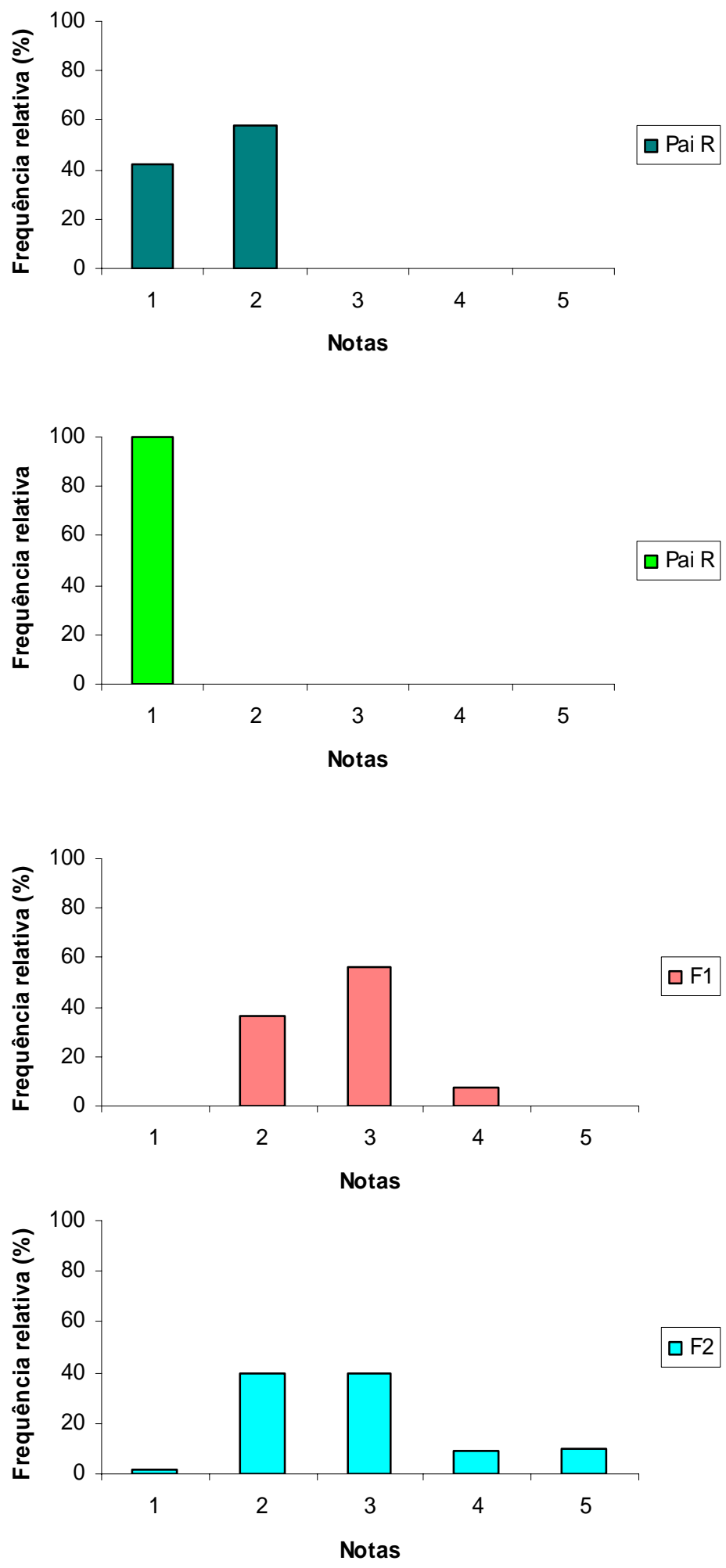

Figura 10 - Histograma de distribuição de freqüência do número de plantas em cada classe de notas das gerações PR, PR, F1 e F2 para o cruzamento \#124 x HV-12. C. annuum. 2002 

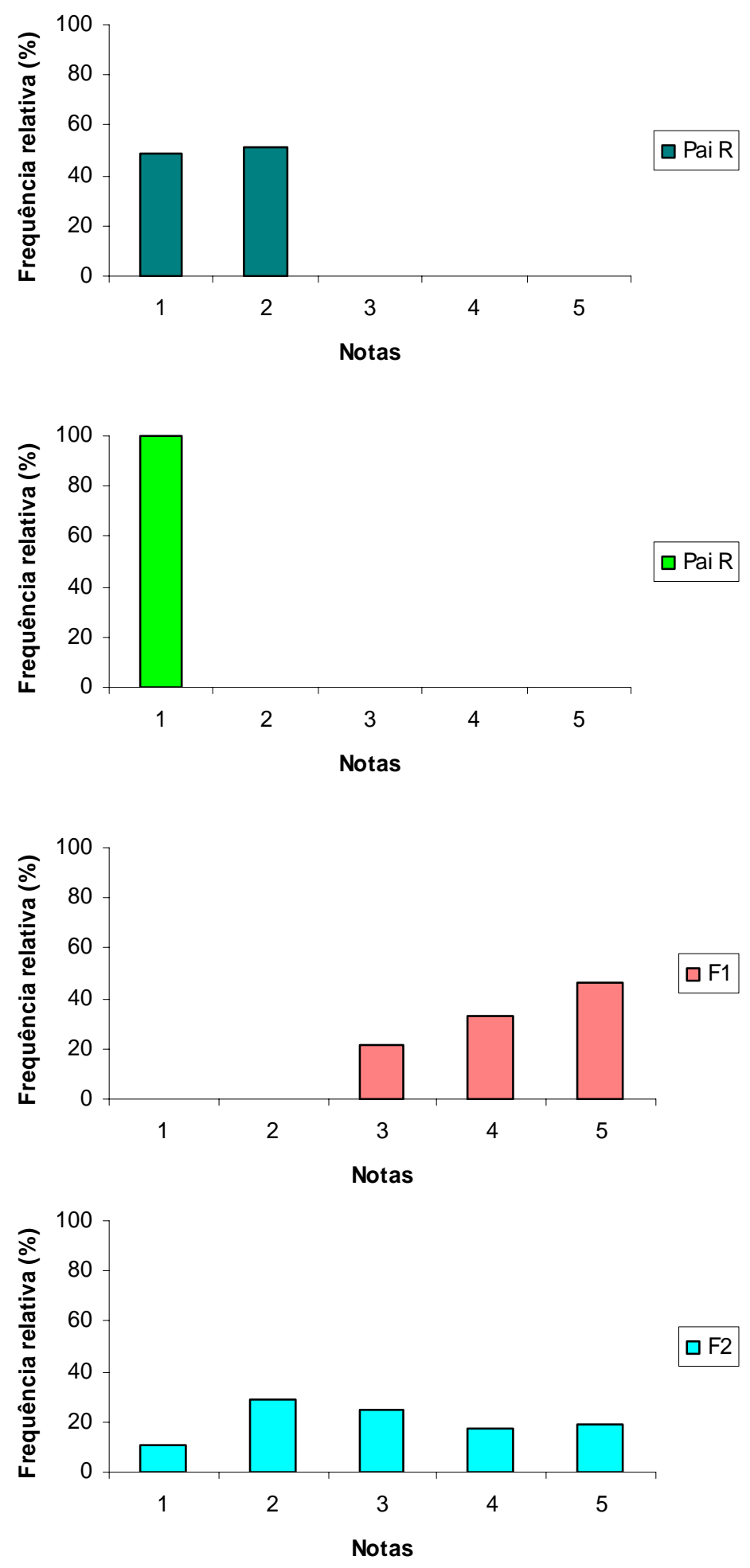

Figura 11 - Histograma de distribuição de freqüência do número de plantas em cada classe de notas das gerações PR, PR, F1 e F2 para o cruzamento Chilli x HV-12. C. annuum. 2002 


\subsection{Conclusões}

- Na espécie C. annuum, dos 99 acessos triados, apenas três foram considerados resistentes: HV-12, Chilli e \#124.

- A base genética da herança mostrou-se complexa com ação gênica de natureza aditiva para o cruzamento HV-12 x 609, aditiva e dominante para 442 x HV-12 e com efeitos dos três componentes de variância genética, aditiva, dominante e epistática, para 428 x HV-12, Chilli x 609 e \#124 x 609.

- A resistência ao oídio em C. annuum foi caracterizada como uma herança recessiva.

- Pelo menos quatro genes estão envolvidos na herança da reação ao oídio

- Os valores de herdabilidade e ganho de seleção estimado foram altos.

- $\mathrm{O}$ progresso de seleção para resistência ao oídio obtido na geração $F_{3}$ foi altamente eficiente.

- Os sistemas genéticos dos progenitores \#124, Chilli diferem do HV-12 quanto aos seus mecanismos genéticos e expressões de resistência. 


\title{
4 HERANÇA DA REAÇÃO DE Capsicum baccatum AO OÍDIO
}

\author{
Autora: SALLY FERREIRA BLAT \\ Orientador: Prof. Dr. CYRO PAULINO DA COSTA
}

\section{Resumo}

O uso de variedades com resistência genética seria a melhor forma de controle do oídio (Leveillula taurica) e as melhores fontes de resistência foram identificadas na espécie de Capsicum baccatum. Apesar disso é desconhecida à genética da herança dessa resistência nessa espécie. O objetivo deste trabalho foi triar os acessos da coleção de C. baccatum da ESALQ/USP, identificando as fontes de resistência além de obter informações sobre a herança dessa reação. Foram triados 37 acessos de C. baccatum. Posteriormente oito híbridos foram obtidos, sendo cinco feitos a partir de acessos resistentes versus suscetíveis e três feitos entre quatro acessos resistentes. As gerações $\mathrm{F}_{2}$ e um retrocruzamento também foram obtidos. As avaliações das reações ao oídio foram feitas na época da frutificação, através de uma escala de notas de acordo com a severidade da doença de 1 (resistente) a 5 (altamente suscetível). A partir das reações obtiveram-se: estimativas do número de locos segregantes, dos coeficientes de herdabilidade, dos progressos esperados com a seleção, o tipo de ação gênica envolvida e avaliadas as reações dos híbridos obtidos do cruzamento entre progenitores resistentes. Dentre os materiais triados $84 \%$ foram considerados resistentes. A herança em $C$. baccatum mostrou-se ser governada por no mínimo de dois a seis pares de genes com ação gênica envolvendo dominância e epistasia. A dominância e epistasia caracterizadas se mostraram negativas, a favor da resistência. As herdabilidades foram altas variando de $51,58 \%$ até $80,78 \%$. As reações dos híbridos e das gerações $F_{2}$ nos cruzamentos entre 
progenitores resistentes mostraram que os genótipos desses progenitores têm o mesmo sistema genético que controla a resistência, não indicando diferenças alélicas.

\title{
INHERITANCE REACTION IN Capsicum baccatum TO POWDERY MILDEW
}

\author{
Author: SALLY FERREIRA BLAT \\ Adviser: Prof. Dr. CYRO PAULINO DA COSTA
}

\section{Summary}

Genetically resistant varieties use is the best way to control powdery mildew (Leveillula taurica) and Capsicum baccatum is the best hot pepper source of resistance. So far, it is unknown its inheritance of powdery mildew for this specie. The present work aimed to screen 37 C. baccatum accesses from the ESALQ/USP Capsicum collection, to identify sources and to elucidate reaction inheritance to powdery mildew in this species. Eight hybrids were obtained, five between resistant and susceptible accesses and three from among four resistant parental crosses. $\mathrm{F}_{2}$ generations and backcrosses was obtained. Reaction evaluations of powdery mildew were carried out during the fruit production using a rating system based on score disease severity using scale varying from 1 (resistant) to 5 (highly susceptible). Reaction to powdery mildew allowed to estimate of segregating loci number, heritability, expected selection gains was made, gene action and to evaluated the reaction to powdery mildew of resistant versus resistant single hybrids. Eighty-four percent of the evaluated materials were considered resistant. Resistance in C. baccatum reaction to powdery mildew showed to be due of two to six pairs of genes with negative dominance and epistasis. Heritability estimates were high and ranged from $51.58 \%$ to $80.78 \%$. Reactions to powdery mildew of hybrids and their $\mathrm{F}_{2}$ generations from resistant progenitors crossing showed genetic similarities with no allelic difference among resistant sources. 


\subsection{Introdução}

As formas de pimenta utilizadas pelo homem pertencem ao gênero Capsicum, família Solanácea. Flores brancas com manchas amarelas difusas na base das pétalas da corola é a principal característica taxonômica da espécie C. baccatum. É originária da Mata Atlântica porém domesticada provavelmente na região das planícies subtropicais da Bolívia (Nuez, 1996). Conhecida como "Aji escabeche" no Peru e na Bolívia, apresenta uma distribuição mais extensiva na América do Sul. Sua ocorrência abrange o Peru Central, Norte da Argentina, Oeste do Paraguai, Sudeste do Brasil, Chile, Equador e Colômbia. É também cultivada na Costa Rica, Hawai, Sul dos EUA e Índia (Nuez, 1996, Bertão, 1993).

Destaca-se o teor vitamínico das pimentas apresentam valores em média de 11.000UI de vitamina A. Os teores de vitamina $C$ total variam de 160 a $245 \mathrm{mg} / 100 \mathrm{~g}$ conforme as espécies de pimenta. Quanto à composição mineral, os teores de cálcio, ferro e fósforo são bem inferiores se comparadas a outras hortaliças.

O sabor picante dos frutos provém da ação de uma substância denominada capsaicina que é acumulada pelas plantas no tecido da placenta e liberada pelo dano físico as células quando se extraem sementes ou corta-se o fruto. O princípio pungente varia de acordo com as cultivares, o local de cultivo, o grau de maturação, entre outros. As cultivares de média pungência (30.000 à 75.000 SHU) são empregadas na produção de picles e de páprica. Pimentas de alta pungência (75 à 120.000 SHU) são usadas na extração de oleoresinas e na produção de molhos caseiros e industrializados. As pimentas também são muito usadas na medicina pelas suas propriedades farmacológicas. Sua propriedade antioxidante pode previnir doenças degenerativas como o câncer, doenças cardiovasculares, Mal de Parkinson e Mal de Alzheimer, minimizando a ação de radicais livres (Reifschneider, 2000).

No Brasil a área plantada de pimenta e pimentão chega a 12.000ha. O volume comercializado do ano de 1998 no CEASA-MG foi de $170.785 \mathrm{~kg}$, sendo $300 \mathrm{~kg}$ de procedência do estado do Espírito Santo, 168.000 de Minas Gerais e 2.485 de São Paulo (FAO, 1999). 
Entre as doenças que afetam o gênero Capsicum está o oídio, causado por Leveillula taurica. Indica-se que as melhores fontes de resistência foram identificadas nas espécies de $C$. baccatum e $C$. chinense. Os acessos da espécie $C$. annuum apresentam baixos níveis de resistência quando comparados a essas duas espécies (Bidari, 1985; Anand et al., 1987; Souza, 2000, Blat, 2002 e Lima, 2002). Segundo Reifschneider et al. (2000), as espécies C. baccatum e C. chinense são bem menos difundidas do que C. annuum e provavelmente os genes que conferem resistência aos patógenos foram mantidos nos acessos durante o processo de domesticação.

Ullasa et al. (1981), testaram a resistência de 300 acessos e variedades de Capsicum, à Leveillula taurica. Encontraram quatro espécies resistentes, C. microcarpum, C. pendulum, C. pubescens e C. longidtilium, e treze linhagens não melhoradas de Capsicum annuum sendo moderadamente resistentes.

Blazquez (1976), testou pimentas do tipo pungente e não pungente, quatro do tipo não pungente foram completamente resistentes e somente Jalapeño foi suscetível. Bidari et al. (1985), testaram 60 variedades das quais somente Puri Orange 2, mostrou-se tolerante.

Zewdie (1994), avaliaram 44 linhagens para incidência de oídio. A incidência de oídio foi severa na maioria das linhagens. A linhagem PBC376 mostrou maior tolerância em produção do que o padrão suscetível. Os acessos PBC151 e PBC171, pertencentes à espécie Capsicum baccatum e C. chinense, mostraram alto nível de resistência em condições de campo.

Souza (2000), avaliou a reação dos acessos do Banco de Germoplasma de Capsicum da Embrapa hortaliças, híbridos e variedades comerciais à L. taurica. Identificaram-se oito acessos imunes: HV12, 4638 e pimentas como ABE (CNPH 36), Kurimoto (CNPH 38), Nélio redonda (CNPH 50), Nélio fina 2 (CNPH 52), Escabeche (CNPH 279) e Malagueta (CNPH 288). A maioria dos materiais (70\%) de Capsicum annuum foi moderadamente suscetível a L. taurica. Nas espécies C. baccatum, C. frutescens e C. chinense a situação se inverteu, ocorrendo menor número de acessos suscetíveis e muitos resistentes. 
Lima (2002) verificou em seus estudos que as espécies C. baccatum, C. chinense e C. frutescens foram pouco variáveis quanto a sua morfologia e apresentaram a maior proporção de acessos resistentes ao oídio, sendo assim indicadas na busca de fontes de resistência ao oídio. Entre os acessos testados em C. baccatum, um foi altamente resistente, dois foram resistentes e apenas um foi moderadamente resistente.

A reação de acessos de C. baccatum tem sido estudada, porém pouco se sabe sobre a herança dessa reação. O presente trabalho visou triar a coleção de C. baccatum da ESALQ/USP identificando os acessos resistentes e suscetíveis e obter informações sobre a genética dessa resistência.

\subsection{Material e Métodos}

\subsubsection{Triagem da coleção de Capsicum baccatum.}

A partir de 37 acessos da coleção de Capsicum baccatum da ESALQ/USP foi feita uma triagem visando-se identificar os materiais resistentes e os suscetíveis ao oídio. As Tabelas 7 e 8 mostram as origens de cada acesso testado.

\subsubsection{Produção de mudas, condução, inoculação e avaliação.}

O trabalho foi instalado e conduzido em ambiente protegido, no Departamento de Produção Vegetal da Escola Superior de Agricultura "Luiz de Queiroz", no município de Piracicaba, SP, que está a uma latitude de $22^{\circ} 42^{\prime} 30^{\prime \prime}$ sul, longitude $47^{\circ} 38^{\prime} 00^{\prime \prime}$ oeste e uma altitude de 546 m (Kuabara, 1984). Segundo a classificação de Köppen, o clima da região é Cwa: subtropical úmido, com três meses mais secos (jun./jul./ago.), chuvas de verão e seca de inverno, temperatura do mês mais quente maior que $22^{\circ} \mathrm{C}$ e média de $21,4^{\circ} \mathrm{C}$.

As mudas foram obtidas em bandejas de 128 células cada, preenchidas com substrato para hortaliças (Gioplant ${ }^{\circledR}$ ) A semeadura foi realizada no mês de setembro de 2000 sendo o transplantio feito 60 dias após esse para vasos plásticos de oito litros contendo uma mistura na proporção de 3:2:1 de areia lavada, vermiculita e turfa.

Os tratos culturais foram os convencionais para a cultura do pimentão em estufa. $\mathrm{O}$ sistema de irrigação adotado foi o de gotejamento, acionado eletronicamente por um 
temporizador, regulado para atender o tempo de irrigação necessitado pelas plantas. $\mathrm{O}$ tutoramento das plantas foi feito através de espaldeira dupla onde as duas linhas de plantas foram tutoradas por fios de arame. A adubação foi feita por fertirrigação, monitorada por um condutivimetro (1.7 EC), usando na fase de muda o produto Kristalon ${ }^{\circledR} 13-40-13,1 \mathrm{~g} / 1$ e após o transplante, o adubo Kristalon ${ }^{\circledR}$ 12-12-36 mais micronutrientes $(500 \mathrm{~g})$, nitrato de cálcio $(300 \mathrm{~g}), \mathrm{Ca} / \mathrm{B}(70 \mathrm{ml})$ e sulfato de magnésio (400g) em 250 litros de água, fornecidos ao tanque duas vezes por semana.

No controle preventivo de pragas e doenças foi utilizado Confidor ${ }^{\circledR}$ (Imidacloprid), Vertimec ${ }^{\circledR}$ (Abamectina) e Aplaud ${ }^{\circledR}$ (Buprofezin) nas dosagens recomendadas. Nenhum tipo de fungicida foi usado para não afetar a reação do hospedeiro ao patógeno.

Sabe-se que a principal forma de disseminação dos esporos do oídio é através do vento, com isso vasos com plantas de pimentão (C. annuum L.) de híbridos comerciais, com alto grau de esporulação foram intercaladas com vasos contendo os acessos a serem testados, na proporção de um vaso contendo plantas suscetíveis para cada 15 de acessos a serem testados, com a finalidade de disseminação da doença. A disseminação natural ocorreu de maneira eficaz e homogênea nas condições do cultivo protegido.

A avaliação da reação dos acessos ao oídio foi feita a cada sete dias por seis semanas consecutivas, iniciando-se na fase de frutificação. Esta foi realizada utilizando uma escala de notas de acordo com a severidade da doença, proposta por Ullasa et al. (1981) (Tabela 1). O nível de severidade da doença foi estabelecido através do critério visual, folhas com diferentes expressões de sintomas foram coletadas e copiadas por um medidor de área foliar (Leaf Área Meter, modelo LI-3000 da Licor) obtendo-se a área foliar total e lesionada. Com base nesta medida estimou-se a severidade da doença. Usando estes modelos referenciais, foi possível padronizar a avaliação da reação do hospedeiro através de notas de 1 a 5 (Tabela 1).

Adotou-se também testemunhas referenciais, cujas reações ao oídio são conhecidas na literatura, para efeito comparativo na avaliação, monitoramento da epidemia e caracterização da reação dos acessos de pimenta ao oídio (Tabela 2). 
Tabela 1. Escala de notas para avaliação da reação de Capsicum a Leveillula taurica

\begin{tabular}{ccc}
\hline Notas & Sintomas & Reação \\
\hline 1 & Resistente, sem sintomas & $\mathrm{R}$ \\
2 & Moderadamente resistente, com 10\% da área foliar afetada & $\mathrm{MR}$ \\
3 & Moderadamente suscetível, com 11-20\% da área foliar afetada & $\mathrm{MS}$ \\
4 & Suscetível, com 21-50\% da área foliar afetada & $\mathrm{S}$ \\
5 & Altamente suscetível, com 51\% ou mais da área foliar afetada & $\mathrm{AS}$ \\
\hline
\end{tabular}

Tabela 2. Testemunhas referenciais de resistência e suscetibilidade com relação à reação à Leveillula taurica

\begin{tabular}{clc}
\hline Hospedeiros referenciais & Procedência & Reação \\
\hline HV12 & INRA, França & $\mathrm{R}$ \\
Chapéu de Bispo & Brasil & $\mathrm{R}$ \\
Margarita & Syngenta/Rogers & $\mathrm{S}$ \\
Magali R & Sakata Agroflora & $\mathrm{S}$ \\
\hline
\end{tabular}

\subsubsection{Análise estatística.}

O delineamento experimental foi em blocos casualizados com parcelas de uma planta por vaso e quatro repetições, totalizando 160 plantas.

Os dados obtidos foram submetidos à análise estatística pelo método "GLIM", realizado com auxílio do Professor José Eduardo Corrente do Departamento de Ciências Exatas da ESALQ/USP. Na análise levaram em conta todos os dados das seis avaliações. O software GLIM utiliza-se de um modelo logístico acumulado, onde se supõe que a distribuição original dos dados é Poisson. Deste modo, com as estimativas dos pontos de corte da análise original, caracterizou-se a reação dos acessos resistentes através das estimativas dos efeitos dos parâmetros (acessos) ajustados e dos respectivos desviospadrão.

Às médias dos tratamentos (acessos) da $6^{\text {a }}$ avaliação final, foi aplicado teste de Tukey a 5\% de probabilidade, apenas para comparação das análises. A análise de variância consta no anexo A. 


\subsubsection{Herança da reação}

\subsubsection{Estimação de parâmetros genéticos.}

Com o objetivo de determinar o modo de herança da reação ao oídio em $C$. baccatum, seis acessos, três com reações de resistência e três de suscetibilidade, foram cruzados entre si no período de abril a junho de 2001, obtendo-se as gerações $\mathrm{F}_{1}$ (Tabela 3). O processo de hibridação foi feito através da emasculação de botões florais, seguidos de polinização usando flores recém abertas (Nuez et al., 1996). Em cada botão polinizado foi colocada uma etiqueta identificando o cruzamento. Para que os frutos híbridos tivessem seu desenvolvimento normal, os frutos provenientes da autofecundação natural da planta foram eliminados.

Tabela 3. Relação dos híbridos

\begin{tabular}{cc}
\hline Híbridos & Reações dos progenitores \\
\hline Ají \# 263 x Chapéu de Bispo & Suscetível x resistente \\
Ají \# 286 x Ají \# 263 & Resistente x suscetível \\
Ají Amarillo \# 269 x Chapéu de Bispo & Suscetível x resistente \\
Pimenta x Chapéu de Bispo & Suscetível x resistente \\
Ají \# 263 x BGH 2994 & Suscetível x resistente \\
\hline
\end{tabular}

\subsection{Produção de mudas, condução, inoculação e avaliação dos híbridos $\left(F_{1}\right)$ e progenitores.}

$\mathrm{Na}$ semeadura das gerações $\mathrm{F}_{1}$, progenitores e testemunhas suscetíveis foram utilizadas bandejas de poliestireno expandido de 128 células, usando substrato para hortaliças marca Gioplant®. O transplante das mudas foi realizado no mês de outubro de 2001, para vasos plásticos de oito litros contendo mistura de solo, vermiculita e turfa (turfa) na proporção de 3:1:1; colocadas em fileiras duplas, num total de quatro fileiras com espaçamento de $1,0 \mathrm{~m}$ entre elas.

Os tratos culturais foram os tradicionais do cultivo em estufa, já descritos no item 4.2.1.1. O delineamento experimental foi inteiramente casualizado com três plantas por vaso, três repetições e 13 tratamentos sendo cinco híbridos, seis progenitores e duas testemunhas suscetíveis, totalizando 117 plantas. 
A obtenção do inoculo, sua disseminação e as avaliações das gerações, foram semelhantes a da etapa de triagem, descrita no item 4.2.1.1, com a diferença de que se tomou como base para a finalização das avaliações as reações das testemunhas suscetíveis (Magali R e Margarita). Quando essas obtiveram nota máxima 5, foram suspensas as avaliações, considerando assim a nota dada naquele momento a cada acesso, sua reação final.

A geração $F_{1}$ foi avaliada em duas etapas, sendo a primeira na ocasião de sua obtenção e posteriormente na avaliação da geração $F_{2}$.

\subsection{Retrocruzamento}

O híbrido Ají \# 286 × Ají \# 263 foi retrocruzado para seu progenitor resistente, Ají \# 286, com o objetivo de aumentar a freqüência gênica e fenotípica de plantas resistentes, para fins de melhoramento e auxiliar no estudo da herança da reação ao oídio.

\subsection{Produção de mudas, condução, inoculação e avaliação dos $F_{2}, F_{1}$, retrocruzamento e progenitores.}

A geração $F_{2}$ foi obtida a partir da autofecundação dos híbridos $\left(F_{1}\right)$.

A semeadura das gerações foi realizada no mês de setembro de 2002 e o transplante no mês de novembro de 2002 para vasos plásticos de oito litros, contendo substrato formulado pela Multiplanta Substrato Agrícola com a seguinte composição: casca de Pinus composta, granulação $10 \mathrm{~mm}$, vermiculita expandida, turfa processada, macro e micro nutrientes fosfato super simples e Humix, areia (5\%) e elemento dispersante de umidade. Os tratos culturais realizados foram os mesmos das etapas anteriores. (item 4.2.1.1).

O delineamento experimental foi inteiramente casualizado com cinco plantas por vaso, totalizando 3.724 plantas (Tabela 4): 
Tabela 4. Número de plantas avaliadas por geração

\begin{tabular}{lcll}
\hline \multicolumn{1}{c}{ Gerações } & n & \multicolumn{1}{c}{ Gerações } & n \\
\hline (Ají \# 263 x Chapéu de Bispo) $P_{1}$ & 60 & (Pimenta x Chapéu de Bispo) $P_{1}$ & 48 \\
$P_{2}$ & 48 & $P_{2}$ & 48 \\
$F_{1}$ & 57 & $F_{1}$ & 60 \\
$F_{2}$ & 518 & $F_{2}$ & 590 \\
(Ají \# 286 x Ají \# 263) $P_{1}$ & 50 & $\left(\right.$ Ají \# 263 x BGH 2994) $P_{1}$ & 60 \\
$P_{2}$ & 60 & $P_{2}$ & 20 \\
$F_{1}$ & 25 & $F_{1}$ & 60 \\
$F_{2}$ & 574 & $F_{2}$ & 577 \\
Retro P & 56 & & \\
(Ají Amarillo \# 269 x C. de Bispo) $P_{1}$ & 40 & Testemunhas \\
$P_{2}$ & 48 & Magali R & 40 \\
$F_{1}$ & 45 & Margarita & 40 \\
$F_{2}$ & 600 & & \\
\hline
\end{tabular}

O estabelecimento da doença foi feito através de plantas de pimentão com alta esporulação, servindo como linhas espalhadoras da doença, na proporção de 1:20, como já descrito no item 4.2.2.1.1. Uma única avaliação diagnosticando a reação da planta ao patógeno foi realizada, quando as plantas estavam em plena frutificação. Adotou-se o critério da avaliação quando as plantas testemunhas, Magali R e Margarita, atingiram nota máxima 5.

\subsection{Análise biométrica dos dados.}

Para a realização das análises biométricas foram utilizados os dados das gerações, $\mathrm{P}_{1}, \mathrm{P}_{2}, \mathrm{~F}_{1}$ e $\mathrm{F}_{2}$ e retrocruzamento. Como havia sido comentado anteriormente, os progenitores e as gerações $F_{1}$ foram avaliadas em duas etapas, na ocasião de sua obtenção e novamente junto a avaliação da geração $F_{2}$. Para que todas as gerações 
tivessem influência das mesmas condições ambientais utilizaram-se para o cálculo das análises os dados referentes a segundo avaliação.

O número de plantas dentro de cada classe de notas foi totalizado e a partir disso, estimadas as médias ponderadas [m], o somatório dos efeitos de aditividade [a] e dominância [d], usando o método de escala conjunta proposto por Cavali e descrito por Mather e Jinks (1984), baseado nas médias esperadas do caráter para as gerações, desconsiderando os efeitos epistáticos. Visando determinar os tipos de ação gênica envolvidas no modelo genético aditivo-dominante, tem-se os seguintes valores esperados:

$$
\begin{gathered}
\mathrm{E}\left[\overline{\mathrm{Y}}_{(\mathrm{PR})}\right]=\mathrm{m}-[\mathrm{a}] \\
\mathrm{E}\left[\overline{\mathrm{Y}}_{(\mathrm{PS})}\right]=\mathrm{m}+[\mathrm{a}] \\
\mathrm{E}\left[\overline{\mathrm{Y}}_{(\mathrm{F} 1)}\right]=\mathrm{m}+[\mathrm{d}] \\
\mathrm{E}\left[\overline{\mathrm{Y}}_{(\mathrm{F} 2)}\right]=\mathrm{m}+(1 / 2)[\mathrm{d}] \\
\mathrm{E}\left[\overline{\mathrm{Y}}_{(\mathrm{RCPR})}\right]=\mathrm{m}-(1 / 2)[\mathrm{a}]+(1 / 2)[\mathrm{d}]
\end{gathered}
$$

Sendo: $\mathrm{m}=$ média geral do caráter;

$[\mathrm{a}]=$ somatório dos efeitos aditivos;

[d] = somatório dos efeitos de dominância;

$\mathrm{E}[\overline{\mathrm{Y}}]=$ esperança matemática da média das gerações $\mathrm{P}_{\mathrm{R}}, \mathrm{P}_{\mathrm{S}}, \mathrm{F}_{1}, \mathrm{~F}_{2}, \mathrm{RC}_{\mathrm{PR}}$.

Admitindo que a maioria dos genes favoráveis para as características estudadas estão acumuladas em uma das linhagens genitoras e os desfavoráveis na outra e que as médias esperadas são expressáveis conforme acima, foi possível estimar os efeitos de m, [a] e [d] considerando as médias das diversas gerações.

Após o cálculo das variâncias foi feito um ajuste do número de graus de liberdade conjunto, para citações de heterogeneidade nas variâncias das gerações conforme Gomes (1990).

A adequação do modelo genético aditivo-dominante, adotado com base nos três parâmetros, m, [a] e [d] foi verificada pelo teste t por meio de contrastes entre médias 
segundo Gomes (1990). Nesses testes comparou-se a média observada da geração $F_{2}$ com seu valor esperado, conforme o modelo. Em caso de significância do teste t, adotouse modelo com efeitos epistáticos, componentes das médias das gerações $(P R=m-[a]+$ $[\mathrm{i}] ; \mathrm{PS}=\mathrm{m}+[\mathrm{a}]+[\mathrm{i}] ; \mathrm{F}_{1}=\mathrm{m}+[\mathrm{d}]+[1] ; \mathrm{F}_{2}=\mathrm{m}+(1 / 2)[\mathrm{d}]+(1 / 4)[1]$ e $\mathrm{RC}_{\mathrm{PR}}=\mathrm{m}-(1 / 2)[\mathrm{a}]+$ $(1 / 2)[d]+(1 / 4)[1])$, além dos efeitos aditivo e dominante. Para mensurar esses efeitos, considerou-se o conteúdo genético do contraste:

$$
\mathrm{C}=\overline{\mathrm{Y}}_{\mathrm{F} 2}-(1 / 4)\left(\overline{\mathrm{Y}}_{\mathrm{PR}}+\overline{\mathrm{Y}}_{\mathrm{PS}}+2 \overline{\mathrm{Y}}_{\mathrm{F} 1}\right)
$$

Cuja esperança matemática é

$$
\mathrm{E}(\mathrm{C})=(1 / 2)[\mathrm{i}]+(1 / 4)[1]
$$

Nesta esperança de C, o parâmetro [i] é a soma dos efeitos epistáticos do tipo aditivo $\mathrm{x}$ aditivo e o parâmetro [1] a soma dos efeitos epistáticos do tipo dominante $\mathrm{x}$ dominante (Mather e Jinks, 1984). Evidentemente $\mathrm{E}(\mathrm{C})$ será nula no caso de ausência de efeitos epistáticos.

Histogramas de distribuição de freqüências de plantas foram construídos, com o intuito de visualizar melhor o comportamento das gerações em cada classe de notas.

$\mathrm{O}$ número de locos segregantes na geração $\mathrm{F}_{2}$ foi estimado somente para casos onde as reações dos progenitores eram contrastantes, de duas formas. Com base na freqüência dos extremos resistentes manifestados no genitor resistente em cada cruzamento e baseado na fórmula para número mínimo de genes segregantes de Burton (1951) citado por Vencovsky \& Barriga (1992):

$$
\operatorname{ng}=\frac{0,25\left(0,75-\beta+\beta^{2}\right) \underline{\alpha^{\underline{2}}}}{\sigma_{g}^{2}}
$$

Onde, $\alpha=\mathrm{P}_{2}-\mathrm{P}_{1}$, sendo $\mathrm{P}_{2}$ a média do progenitor mais alto, $\beta=\left(\mathrm{F}_{1}-\right.$ $\left.\mathrm{P}_{1}\right) / \alpha$, sendo $\mathrm{F}_{1}$ e $\mathrm{P}_{1}$, as médias das gerações $\mathrm{F}_{1}$ e do progenitor 1 e $\sigma_{\mathrm{g}}^{2}$ a variância genética em $\mathrm{F}_{2}$.

Podem ocorrer diferenças na estimativa do número de genes calculada pela freqüência e pela fórmula. Pela fórmula, se está mais sujeito a possibilidade de erros de 
estimação, pois ela envolve um número de estimativas (médias e variâncias) maior se comparado ao método das freqüências. Convém observar que a expressão de $\mathrm{n}_{\mathrm{g}}$ subestima o número de locos segregantes na presença de ligação gênica e nos casos em que as linhagens progenitoras não são completamente contratantes. Apesar disso os dois procedimentos foram usados para confrontar e reforçar os resultados.

Os coeficientes de herdabilidade também foram calculados para cada cruzamento conforme segue:

$$
\mathrm{h}^{2}=\sigma_{\mathrm{g}}^{2} / \sigma_{\mathrm{f}}^{2}
$$

onde, $\mathrm{h}^{2}=$ coeficiente de herdabilidade

$\sigma_{\mathrm{g}}^{2}=$ variância genética

$\sigma_{\mathrm{f}}^{2}=$ variância fenotípica

A variância genética e a variância fenotípica foram estimadas por:

$$
\begin{gathered}
\sigma_{\mathrm{g}}^{2}=\sigma_{\mathrm{F} 2}^{2}-\left[\left(\sigma_{\mathrm{P} 1}^{2}+\sigma_{\mathrm{P} 2}^{2}+2 \sigma_{\mathrm{F} 1}^{2}\right) / 4\right] \\
\sigma_{\mathrm{f}}^{2}=\sigma_{\mathrm{F} 2}^{2}
\end{gathered}
$$

A partir dos coeficientes de herdabilidade foram calculados os ganhos de seleção esperados para a geração $F_{3}$. Simulou-se seleção das plantas com notas 1 e 2 .

$$
\mathrm{Gs} \leq \mathrm{ds} \cdot \mathrm{h}^{2}
$$

Onde, Gs = ganho de seleção

ds $=$ diferencial de seleção

$\mathrm{h}^{2}=$ coeficiente de herdabilidade

Sendo o diferencial de seleção calculado por:

$$
\mathrm{ds}=\overline{\mathrm{Y}}_{\mathrm{s}}-\overline{\mathrm{Y}}_{\mathrm{F} 2}
$$

Onde, $\overline{\mathrm{y}}_{\mathrm{s}}=$ média geral das progênies selecionadas.

$\overline{\mathrm{y}}_{\mathrm{F} 2}=$ média da geração $\mathrm{F}_{2}$.

Os coeficientes de herdabilidade e os ganhos de seleção foram calculados com base na herdabilidade no sentido amplo. A estimativa do progresso (Gs) é adequada em 
casos de ausência de dominância. Havendo evidência de dominância o valor de Gs estará super estimado, servindo apenas como referencial.

As análises biométricas foram feitas com auxílio do Prof. Dr. Roland Vencovsky do Departamento de Genética da ESALQ/USP.

\subsubsection{Reação de híbridos resistentes ao oídio em C. baccatum.}

Cruzamentos entre quatro progenitores resistentes foram realizados com o objetivo de avaliar as reações das gerações obtidas desses cruzamentos, verificando se os mecanismos genéticos de resistência desses progenitores são similares (Tabela 5).

A técnica de hibridação já descrita no item 4.2.2.1 foi de emasculação seguida de polinização.

Tabela 5. Relação dos híbridos

\begin{tabular}{cc}
\hline Híbridos & Reações \\
\hline Ají \# 284 x Chapéu de Bispo & Resistente x resistente \\
Ají Amarillo \# 267 x Chapéu de Bispo & Resistente x resistente \\
BGH 0620 x Chapéu de Bispo & Resistente x resistente \\
\hline
\end{tabular}

4.2.2.2.1 Produção de mudas, condução, inoculação e avaliação dos híbridos $\left(F_{1}\right)$ e progenitores.

A produção das mudas, tratos culturais, inoculação e as avaliações foram realizadas da mesma maneira já descrita na etapa de triagem (item 4.2.1.1). O delineamento experimental foi inteiramente casualizado com três plantas por parcela, três repetições e 9 tratamentos sendo três híbridos, quatro progenitores e duas testemunhas suscetíveis, totalizando 81 plantas.

\subsection{Produção de mudas, condução, inoculação e avaliação $\operatorname{dos} F_{2}, F_{1}$, e progenitores.}

Os procedimentos metodológicos para a realização das etapas, desde a produção de mudas até as avaliações, foram realizadas da mesma forma já relatada no item 4.2.2.1.3. 
O delineamento experimental foi inteiramente casualizado com cinco plantas por vaso, compondo um total de 2244 plantas: (Tabela 6).

Tabela 6. Número de plantas avaliadas por geração de C. baccatum avaliadas segundo escala de notas

\begin{tabular}{lc}
\hline \multicolumn{1}{c}{ Gerações } & N $^{\mathbf{0}}$ de Plantas \\
\hline (Ají \# 284 x Chapéu de Bispo) $\mathrm{P}_{1}$ & 42 \\
$\mathrm{P}_{2}$ & 48 \\
$\mathrm{~F}_{1}$ & 30 \\
$\mathrm{~F}_{2}$ & 560 \\
(Ají Amarillo \# 267 x Chapéu de Bispo) $\mathrm{P}_{1}$ & 46 \\
$\mathrm{P}_{2}$ & 48 \\
$\mathrm{~F}_{1}$ & 53 \\
$\mathrm{~F}_{2}$ & 586 \\
$\left(\right.$ BGH 0620 x Chapéu de Bispo) $\mathrm{P}_{1}$ & 56 \\
$\mathrm{P}_{2}$ & 48 \\
$\mathrm{~F}_{1}$ & 59 \\
$\mathrm{~F}_{2}$ & 588 \\
Testemunhas & \\
Magali $\mathrm{R}$ & 40 \\
Margarita & 40 \\
\hline
\end{tabular}

\subsection{Análise biométrica dos dados.}

Para a realização das análises biométricas foram utilizados os dados das gerações, $\mathrm{P}_{1}, \mathrm{P}_{2} \mathrm{~F}_{1}$ e $\mathrm{F}_{2}$. Como havia sido comentado anteriormente, os progenitores e as gerações $F_{1}$ foram avaliadas em duas etapas, na ocasião de sua obtenção e novamente junto a avaliação da geração $F_{2}$. Para que todas as gerações tivessem influência das mesmas condições ambientais utilizaram-se para o cálculo das análises os dados referentes a $2^{\mathrm{a}}$ avaliação. 
Feita as avaliações, o número de plantas dentro de cada classe de notas foi totalizado e estimadas as médias ponderadas [m], o somatório dos efeitos de aditividade [a] e dominância [d] visando verificar se havia ou não diferenças entre os mecanismos genéticos dos progenitores. A adequação do modelo foi verificada pelo teste t por meio de contrastes entre médias segundo Gomes (1990). Em caso de significância do teste t, adotou-se modelo com efeitos epistáticos. Um melhor detalhamento dessa análise foi descrito no item 4.2.2.1.4.

Após o cálculo das variâncias foi feito um ajuste do número de graus de liberdade conjunto, para citações de heterogeneidade nas variâncias das gerações conforme Gomes (1990).

Histogramas de distribuição das gerações foram feitos para visualizar melhor o comportamento das médias dentro de cada classe de notas nas diferentes gerações.

\subsection{Resultados e Discussão}

\subsubsection{Triagem da coleção de Capsicum baccatum.}

Ao contrário do que ocorreu na espécie $C$. annuum pode-se observar que em $C$. baccatum $84 \%$ dos acessos testados foram considerados resistentes (Tabela 7). Esta proporção de alta incidência de acessos resistentes ao oídio na espécie C. baccatum também foi confirmada por Shifriss et al. (1992), Daubeze et al. (1995), Souza \& Café Filho (2000) e Lima (2002).

De acordo com a escala de notas utilizada na avaliação da doença, dentre os 37 acessos testados, 31 foram considerados de resistentes a moderadamente resistentes (médias 1 a 2,50), cinco foram moderadamente suscetíveis (de 2,75 a 3,50) e um foi suscetível $(4,50)$ (Tabelas 7 e 8 ). Esses resultados concordam na proporção de acessos resistentes obtidos por Lima (2002), em que entre os cinco acessos de C. baccatum testados, um foi altamente resistente, três foram resistentes e um foi moderadamente resistente.

O grau de esporulação verificado nos acessos de C. baccatum caracterizou-se por ser mais reduzido quando comparado com $C$. annuum. O único acesso que mais se destacou pela sua alta suscetibilidade foi o Aji \# 263 com média de 4,50 e grande 
esporulação. Segundo Reifschneider et al. (1998), o fato de as espécies C. baccatum, C. chinense e C. frutescens serem altamente resistentes deve-se ao processo de domesticação. Estas espécies são bem menos cultivadas do que C. annuum e possivelmente os genes de resistência a pragas e doenças foram preservados em sua domesticação.

Os acessos suscetíveis apresentaram médias relativamente baixas, variando de 2,75 à 3,50, com exceção do Aji\#263 que obteve médias de 4,50 (Tabela 8). A figura 1 mostra a evolução da infecção de oídio nos acessos de C. baccatum no período de avaliação. Se comparado aos acessos suscetíveis na espécie C. annuum, o período de latência desses acessos foi relativamente lento.

Um relato interessante que se pôde obter neste primeiro experimento foi que o acesso SGMO (tipo Chapéu de Frade), cedido pelo Dr. Robert Heyser ${ }^{1}$, melhorista de pimentão da Semins Vegetable Seeds, como padrão referencial de resistência ao oídio em C. baccatum, mostrou-se moderadamente suscetível, com média 3,5. Uma hipótese para explicar essa reação diferencial do acesso SGMO seria que a patogenicidade poderia ser devida a eventuais raças de Leveillula taurica, sendo as da Califórnia diferentes das que ocorrem no Brasil. Contudo, até o presente momento, não se acredita na existência de raças para o oídio do pimentão, sugerindo a explicação mais provável que os resultados seriam devidos as diferentes condições ambientais, conforme Lima (2002). Observou-se também que até a quarta avaliação o acesso SGMO obteve média 1,50 e somente nas duas últimas avaliações é que essa reação mudou drasticamente passando a 3,50 (Tabela 8). Variações de condições ambientais podem ter influenciado nessa mudança.

O sintoma de "flecks" observado em alguns acessos de C. annuum também ocorreu em C. baccatum com maior freqüência. É um tipo de reação de hipersensibilidade da planta ao patógeno, como um mecanismo de defesa. A planta é infectada pelo oídio, porém os sintomas restringem-se a pontuações, micro-lesões sem esporulação. Este sintoma também foi verificado por Lima (2002) que criou dentro da sua escala de avaliação de 0 a 5 , a nota 2 (manchas cloróticas restritas, sem

${ }^{1}$ Dr. Robert Heyser, comunicação pessoal (2001). 
esporulação), específica para este tipo de sintoma. De acordo com este autor, acessos resistentes apresentam períodos de latência mais prolongados, caracterizados pela presença de manchas cloróticas que progridem para necroses bem delimitadas. Posteriormente ocorre o amarelecimento dessas folhas, possivelmente pela ação da biossíntese de etileno e conseqüentemente ocorre a defoliação. É um mecanismo válido e funcional porque elimina a fonte de inoculo reduzindo a epidemia. Este tipo de sintoma é muito comum quando ocorre o fenômeno da adjacência de uma fonte esporulante e disseminadora de oídio próxima aos acessos resistentes.

Esse tipo de reação de hipersensibilidade é geralmente controlado por genes maiores e parece estar ligado a raça específica. Um conceito desenvolvido e estendido por Russel (1976) estudando a resistência de cultivares a ferrugem do trigo, mostrou que seis diferentes mecanismos de resistência podem operar em plantas adultas. (a) Um de resistência à deposição do esporo na planta, (b) resistência à germinação dos esporos em função da inibição dessa pela superfície da folha, (c) resistência à penetração do patógeno, (d) hipersensibilidade ocorrendo morte das células do hospedeiro no local de penetração, (e) resistência ao crescimento do patógeno, no qual o desenvolvimento do fungo é inibido reduzindo a infecção e esporulação, e (f) prolongamento do período de latência. 
Tabela 7. Listagem dos acessos resistentes pela análise GLIM e médias de suas reações, por avaliação. C. baccatum. 2001

\begin{tabular}{lcc}
\hline \multicolumn{1}{c}{ Acessos } & Origem & Médias \\
\hline Murupi IH 1492 & Manaus - PA & $1,00 \mathrm{E}$ \\
ICA \#60 & Colômbia & $1,00 \mathrm{E}$ \\
Pimenta II & Várzea Grande - MT & $1,00 \mathrm{E}$ \\
Habanera BG 592 & México & $1,00 \mathrm{E}$ \\
BGH 5025 & Viçosa - MG & $1,00 \mathrm{E}$ \\
BGH 4301 & Viçosa - MG & $1,00 \mathrm{E}$ \\
BGH 4176 & Viçosa - MG & $1,00 \mathrm{E}$ \\
BGH 2994 & Viçosa - MG & $1,00 \mathrm{E}$ \\
BGH 1603 & Viçosa - MG & $1,00 \mathrm{E}$ \\
RFG/FAO 553 & Gatemala & $1,00 \mathrm{E}$ \\
Chapéu de Bispo & Brasil & $1,25 \mathrm{DE}$ \\
Pim. Piranga & Brasil & $1,25 \mathrm{DE}$ \\
Pimenta Bode & Brasil & $1,25 \mathrm{DE}$ \\
ICA \# 65 & Colômbia & $1,25 \mathrm{DE}$ \\
Guarnica 243 & Bolívia & $1,25 \mathrm{DE}$ \\
BGH 4366 & Viçosa - MG & $1,25 \mathrm{DE}$ \\
BGH 1037 & Viçosa - MG & $1,25 \mathrm{DE}$ \\
BGH 1022 & Viçosa - MG & $1,25 \mathrm{DE}$ \\
Aji Amarillo \#67 & Bolívia & $1,25 \mathrm{DE}$ \\
Aji \#286 & Bolívia & $1,25 \mathrm{DE}$ \\
Yerba Mala 251 & Bolívia & $1,50 \mathrm{DE}$ \\
Pimenta Cambuci & Caraguatatuba-SP & $1,50 \mathrm{DE}$ \\
Aji Limo & Bolívia & $1,50 \mathrm{DE}$ \\
Aji Amarillo \#267 & Bolívia & $1,75 \mathrm{CDE}$ \\
Aji Hojo \#268 & Bolívia & $2,00 \mathrm{BCDE}$ \\
BGH 1675 & Viçosa - MG & $2,25 \mathrm{BCDE}$ \\
BGH 0620 & Viçosa - MG & $2,25 \mathrm{BCDE}$ \\
Arivivi \#212 & Bolívia & $2,25 \mathrm{BCDE}$ \\
Aji Amarillo \#60 & Bolívia & $2,25 \mathrm{BCDE}$ \\
Aji \#284 & Bolívia & $2,50 \mathrm{BCDE}$ \\
Pimenta Coração & Cuiabá - MT & $2,50 \mathrm{BCDE}$ \\
\hline 1. Médias seguidas pela mesma letra na coluna, não diferem entre si, ao nível de 5\% de probabilidade pelo \\
teste de Tukey. & & \\
& &
\end{tabular}


Tabela 8. Listagem dos acessos suscetíveis pela análise GLIM e médias de suas reações. C. baccatum. 2001

\begin{tabular}{|c|c|c|c|c|c|c|c|}
\hline \multirow[b]{2}{*}{ Acessos } & \multirow[b]{2}{*}{ Origem } & \multicolumn{6}{|c|}{ Média de notas por avaliação ${ }^{1}$ (Dias) } \\
\hline & & 7 & 14 & 21 & 28 & 35 & 42 \\
\hline Pimenta & Mogi Guaçu- SP & 1,00 & 1,00 & 1,75 & 2,50 & 2,75 & $2,75 \mathrm{BCD}$ \\
\hline Aji Amarillo \#264 & Bolívia & 1,00 & 1,00 & 1,75 & 2,25 & 2,50 & $2,75 \mathrm{BCD}$ \\
\hline Aji Amarillo \#269 & Bolívia & 1,00 & 1,00 & 1,75 & 2,00 & 2,75 & $3,25 \mathrm{ABC}$ \\
\hline SGMO & Seminis & 1,00 & 1,00 & 1,00 & 1,50 & 2,75 & $3,50 \mathrm{AB}$ \\
\hline ICA \#146 & Colômbia & 1,00 & 1,50 & 2,50 & 3,00 & 3,25 & $3,50 \mathrm{AB}$ \\
\hline Aji \#263 & Bolívia & 1,00 & 1,25 & 2,00 & 3,00 & 4,50 & $4,50 \mathrm{~A}$ \\
\hline
\end{tabular}

1. Médias seguidas pela mesma letra na coluna, não diferem entre si, ao nível de $5 \%$ de probabilidade, pelo teste de Tukey.

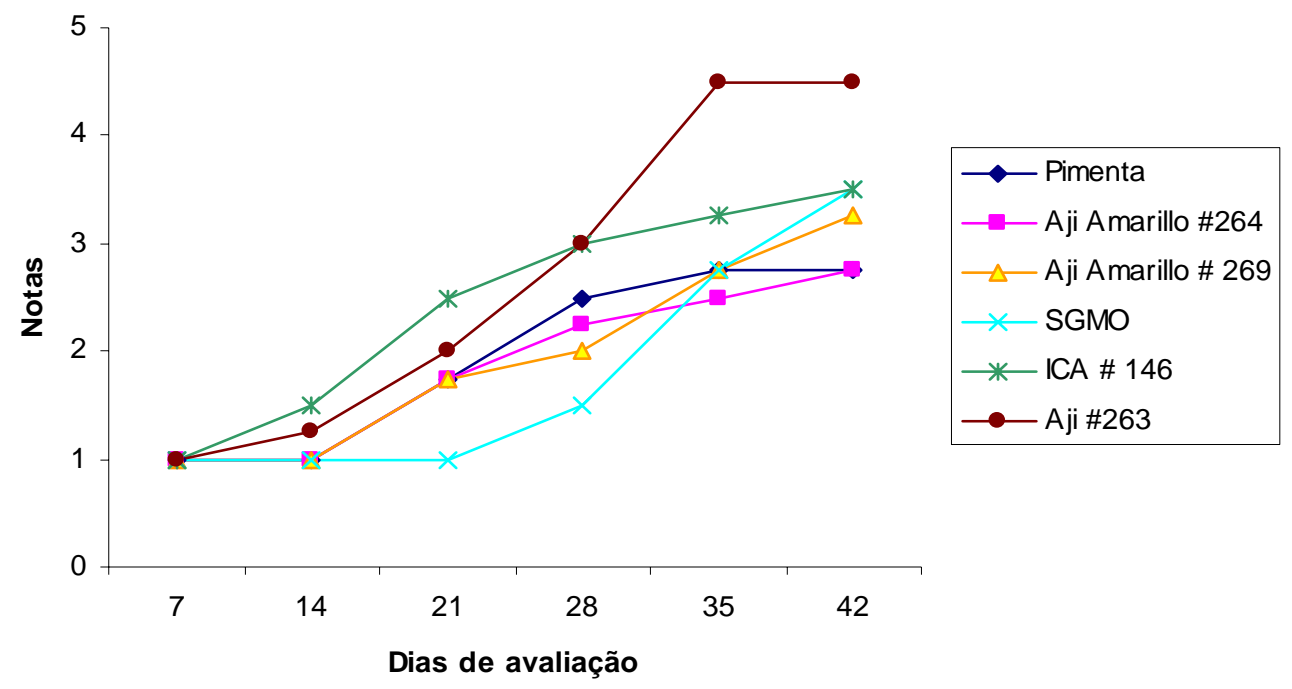

Figura 1 - Progresso da doença dos acessos suscetíveis de C.baccatum

\subsubsection{Herança da reação}

\subsubsection{Estimação de parâmetros genéticos.}

Os progenitores foram consistentes quanto suas reações de resistência ou suscetibilidade anteriormente devidamente discriminadas na etapa de triagem. É interessante notar que a reação de suscetibilidade em C. baccatum é diferente dos sintomas de oídio em C. annuum sendo menos acentuada e com menor esporulação. Com exceção do acesso Aji \# 263, cujas médias nas duas avaliações foram de 4,00 e 4,42 , os outros dois progenitores apresentaram reações de moderadamente suscetível a 
suscetível, com médias de 2,78 e 3,37 para Aji Amarillo \# 269; 2,55 e 3,52 para pimenta, diferindo bem dos materiais suscetíveis de $C$. annuum que rapidamente alcançaram a nota 5 (Tabela 10, Figuras de 2 a 6).

As médias das reações dos progenitores suscetíveis e das gerações $\mathrm{F}_{1}$ diferiram um pouco nas duas avaliações. As épocas para cada avaliação foram distintas, inclusive em anos diferentes, sugerindo efeitos ambientais diferentes. Segundo Lima (2002), as condições ambientais podem influenciar fortemente na infecção e colonização do hospedeiro. Daubeze et al. (1995), também obtiveram reações diferenciadas nas gerações $F_{1}$ nos seus dois anos de experimento, sugerindo que a intensidade da doença nesses dois anos foi diferente.

Observou-se também na espécie C. baccatum, tanto para os progenitores quanto para as gerações $F_{1}$, uma acentuada defoliação mesmo com baixos índices de suscetibilidade. Esse fenômeno foi também observado por Lima (2002), não somente em C. baccatum, como em C. chinense e C. frutescens, atribuindo tal fato à característica fenológica da planta e a variações de umidade e temperatura.

Analisando-se as médias obtidas na segunda avaliação principalmente, nota-se que as plantas da geração $F_{1}$ e $F_{2}$ tenderam a resistência, tendo a geração $F_{1}$ do cruzamento Aji \#263 x Chapéu de Bispo a maior média, 2,47 (Tabela 10). Pode-se observar que as maiores proporções de plantas da geração $F_{2}$ estão entre as notas 1 e 2, representando 51,9\% no cruzamento Aji \#263 x Chapéu de Bispo; 90,2\% em Aji \#286 x Aji \# 263; 59,2\% em Aji Amarillo \# 269 x Chapéu de Bispo; 72,6\% em Pimenta x Chapéu de Bispo e 92,7\% em Aji \# 263 x BGH 2994, respectivamente (Tabela 9, Figuras 2 a 6).

Entre os híbridos que mais se destacaram pela maior freqüência de plantas resistentes estão, Aji \#286 x Aji \#263, com médias de 1,36 e na geração $F_{2}$ média de 1,53 e também Aji \#263 x BGH 2994 com média de 1,07 na geração $F_{1}$ e 1,45 na geração $\mathrm{F}_{2}$ (Tabela 10).

Desconhece-se na literatura a herança da resistência e o tipo de ação gênica em relação ao oídio nas espécies de pimenta, C. baccatum e C. chinense. Pode-se dizer, com isso, que este estudo é inédito e de grande importância, pois são espécies que se destacam por suas fontes de resistência a várias doenças de doenças de Capsicum. 
Os resultados da análise genética indicaram que houve manifestação de dominância em quase todos os cruzamentos realizados. A heterose foi significativamente negativa em todos os cruzamentos; com exceção do Aji Amarillo \# 269 x Chapéu de Bispo, mostrando que houve diferenças entre a média dos pais e a da geração $F_{1}$, sendo essa inferior com menor severidade de oídio do que os progenitores (Tabela 11). Este fato é vantajoso quando o melhorista pretende explorar híbridos. O efeito da dominância da resistência em $C$. baccatum mostrou ser diferente e ao contrário da espécie $C$. annuum que foi recessiva. Esse tipo de resultado era esperado, pois na etapa de triagem notou-se que as espécies reagiram ao oídio de forma completamente oposta. Enquanto $84 \%$ dos acessos de C. baccatum foram resistentes, somente $5 \%$ dos acessos de $C$. annuum apresentaram a mesma reação de resistência. É valioso lembrar que a espécie de pimenta C. baccatum, assim como C. chinense e C. frutescens são espécies cujo melhoramento tem sido praticado de maneira menos intensiva pelo homem, sem erosão genética de genes valiosos.

Nos cruzamentos em que houve manifestação de dominância, também apresentaram na geração $\mathrm{F}_{2}$ epistasia altamente significativa e útil para um programa de melhoramento, pois assim como a heterose, a epistasia também foi negativa, indicando menor freqüência observada de plantas doentes na geração $F_{2}$.

Quando se fez o retrocruzamento de Aji \#286 x Aji \#263 para o respectivo progenitor resistente, observou-se que o número de plantas resistentes (nota 1) aumentou muito, tendo uma média de 1,07. Confirmando os resultados apresentados pela geração F2, houve manifestação de epistasia significativa na geração do retrocruzamento.

Pode-se dizer que nos cruzamentos Ají \# 263 x Chapéu de Bispo, Ají \# 286 x Ají \# 263, Pimenta x Chapéu de Bispo e Ají \# 263 x BGH 2994, o tipo de ação gênica detectada foi aditiva, dominante e epistática enquanto que para Ají Amarillo \# $269 \mathrm{x}$ Chapéu de Bispo foi somente aditiva.

O número de genes segregantes variou conforme o cruzamento e estimativas, mas de maneira geral as estimativas baseadas pelas freqüências foram próximas às calculadas pela fórmula de Burton (1951). No Aji \#263 x Chapéu de Bispo pelo menos dois locos segregantes manifestaram-se, para Aji \# 263 x BGH 2994, de três a cinco pares de genes 
mostraram-se envolvidos e para Aji \# 286 x Aji \# 263 no mínimo de quatro a seis genes governam a herança da resistência ao oídio (Tabela 10). Convêm lembrar que heranças envolvendo vários genes são difíceis de serem interpretadas no modelo mendeliano. Infere-se que quanto maior o número de genes maior será a dificuldade seletiva, maior influência ambiental. Além do mais características poligênicas, com quatro a cinco locos, implicam em estratégias de melhoramento com seleção recorrente para aumentar a freqüência de alelos favoráveis relacionados com maior resistência ao oídio.

Verificou-se que os valores de herdabilidade foram altos, acima de 50\% para todos os cruzamentos, indicando que provavelmente este caráter possa ser selecionado em gerações menos avançadas, utilizando-se de alta pressão de seleção. O cruzamento que mais se destacou foi Ají \# 263 x BGH 2994, mostrando que 80,78\% da superioridade da planta mãe foi retida na descendência. Esses resultados e parâmetros genéticos são de fundamental importância para o melhorista, pois mostram a grande variabilidade encontrada e que pode ser explorada na geração $\mathrm{F}_{2}$ (Tabela 10).

A alta herdabilidade com relação a resistência ao patógeno indica que o processo seletivo será eficiente nesta espécie de pimenta. O maior ganho de seleção foi estimado para a geração $\mathrm{F}_{3}$ do cruzamento Ají \# 263 x Chapéu de Bispo, esperando-se uma diminuição no valor da média de 27,6\%. Para as gerações $F_{3}$ de Ají \# 286 x Ají \# 263 e Ají \# 263 x BGH 2994, cujas médias das gerações $F_{1}$ e $F_{2}$ foram as menores, a expectativa será de um menor ganho, 7,2\% e 7,6\% respectivamente (Tabela 10 ). 
Tabela 9. Número de plantas em cada classe, de acordo com a escala de notas para resistência a Leveillula taurica em condições de casa de vegetação. C. baccatum. 2003

\begin{tabular}{|c|c|c|c|c|c|c|}
\hline Gerações $^{1}$ & & $\begin{array}{c}\text { R } \\
\text { Nota } 1 \\
\end{array}$ & $\begin{array}{c}\text { MR } \\
\text { Nota } 2\end{array}$ & $\begin{array}{c}\text { MS } \\
\text { Nota } 3\end{array}$ & $\begin{array}{c}\text { S } \\
\text { Nota } 4\end{array}$ & $\begin{array}{c}\text { AS } \\
\text { Nota } 5\end{array}$ \\
\hline & $\mathrm{PR}^{\bullet}$ & 4 & 5 & 0 & 0 & 0 \\
\hline \multirow[t]{2}{*}{ Chapéu de Bispo } & $\mathrm{PR}^{\bullet \bullet}$ & 24 & 24 & 0 & 0 & 0 \\
\hline & $\mathrm{PR}^{\bullet}$ & 9 & 0 & 0 & 0 & 0 \\
\hline \multirow[t]{2}{*}{ Ají \# 286} & $\mathrm{PR}^{\bullet \bullet}$ & 50 & 0 & 0 & 0 & 0 \\
\hline & $\mathrm{PR}^{\bullet}$ & 9 & 0 & 0 & 0 & 0 \\
\hline \multirow[t]{2}{*}{ BGH 2994} & $\mathrm{PR}^{\bullet \bullet}$ & 20 & 0 & 0 & 0 & 0 \\
\hline & $\mathrm{PS}^{\bullet}$ & 0 & 0 & 0 & 9 & 0 \\
\hline \multirow[t]{2}{*}{ Ají \# 263} & $\mathrm{PS}^{\bullet \bullet}$ & 0 & 0 & 0 & 35 & 25 \\
\hline & $\mathrm{PS}^{\bullet}$ & 0 & 2 & 7 & 0 & 0 \\
\hline \multirow[t]{2}{*}{ Ají Amarillo \# 269} & $\mathrm{PS}^{\bullet \bullet}$ & 0 & 0 & 25 & 15 & 0 \\
\hline & $\mathrm{PS}^{\bullet}$ & 0 & 4 & 5 & 0 & 0 \\
\hline \multirow[t]{2}{*}{ Pimenta } & $\mathrm{PS}^{\bullet \bullet}$ & 0 & 0 & 23 & 25 & 0 \\
\hline & $\mathrm{TS}^{\bullet}$ & 0 & 0 & 0 & 0 & 9 \\
\hline \multirow[t]{2}{*}{ Magali R } & $\mathrm{TS}^{\bullet \bullet}$ & 0 & 0 & 0 & 0 & 40 \\
\hline & $\mathrm{TS}^{\bullet}$ & 0 & 0 & 0 & 0 & 9 \\
\hline \multirow[t]{2}{*}{ Margarita } & $\mathrm{TS}^{\bullet \bullet}$ & 0 & 0 & 0 & 0 & 40 \\
\hline & $\mathrm{F}_{1}^{\bullet}$ & 0 & 5 & 4 & 0 & 0 \\
\hline \multirow[t]{3}{*}{ Ají \# 263 x Ch. de Bispo } & $\mathrm{F}_{1}^{\bullet \bullet}$ & 0 & 30 & 27 & 0 & 0 \\
\hline & $\mathrm{F}_{2}^{\bullet \bullet}$ & 115 & 154 & 148 & 79 & 22 \\
\hline & $\mathrm{F}_{1}^{\bullet}$ & 0 & 9 & 0 & 0 & 0 \\
\hline \multirow[t]{4}{*}{ Ají \# 286 x Ají \# 263} & $\mathrm{~F}_{1}^{\bullet \bullet}$ & 16 & 9 & 0 & 0 & 0 \\
\hline & $\mathrm{F}_{2}^{\bullet \bullet}$ & 333 & 185 & 50 & 6 & 0 \\
\hline & $\mathrm{RCPR} \bullet \bullet$ & 52 & 4 & 0 & 0 & 0 \\
\hline & $\mathrm{F}_{1}^{\bullet}$ & 0 & 0 & 9 & 0 & 0 \\
\hline \multirow[t]{3}{*}{ Ají Amarillo \# 269 x Ch. de Bispo } & $\mathrm{F}_{1}^{\bullet \bullet}$ & 0 & 28 & 17 & 0 & 0 \\
\hline & $\mathrm{F}_{2}^{\bullet \bullet}$ & 113 & 242 & 180 & 65 & 0 \\
\hline & $\mathrm{F}_{1}^{\bullet}$ & 0 & 1 & 4 & 4 & 0 \\
\hline \multirow[t]{3}{*}{ Pimenta x Chapéu de Bispo } & $\mathrm{F}_{1}^{\bullet \bullet}$ & 0 & 43 & 14 & 3 & 0 \\
\hline & $\mathrm{F}_{2}^{\bullet \bullet}$ & 154 & 274 & 149 & 13 & 0 \\
\hline & $\mathrm{F}_{1}^{\bullet}$ & 6 & 3 & 0 & 0 & 0 \\
\hline \multirow[t]{2}{*}{ Ají \# 263 x BGH 2994} & $\mathrm{~F}_{1}^{\bullet \bullet}$ & 56 & 4 & 0 & 0 & 0 \\
\hline & $\mathrm{F}_{2}^{\bullet \bullet}$ & 371 & 164 & 32 & 8 & 2 \\
\hline
\end{tabular}

Resultados obtidos em fevereiro de 2002 (primeira avaliação) - na obtenção da geração $F_{1}$.

• Resultados obtidos em setembro de 2002 (segunda avaliação) - na obtenção da geração $F_{2}$.

1. $\quad$ PR - Progenitor resistente, PS - progenitor suscetível, RC PR - retrocruzamento, TS Testemunha suscetível. 
Tabela 10. Estimativas de médias, variâncias, do número de locos segregantes e da herdabilidade $\left(\mathrm{h}^{2}\right)$ nas diferentes gerações de cinco cruzamentos e ganho de seleção esperado em $\mathrm{F}_{3}(\mathrm{Gs})$,. C. baccatum. 2003

\begin{tabular}{|c|c|c|c|c|c|c|c|c|}
\hline & & & & & & ocos & $\mathbf{h}^{2}$ & Gs \\
\hline Gerações & & $\mathbf{n}$ & Médias & Variâncias & Freq & Fórm. & $(\%)$ & (\%) \\
\hline & $\mathrm{PR}^{\bullet}$ & 9 & 1,55 & 0,278 & & & & \\
\hline Chapéu de Bispo & $\mathrm{PR}^{\bullet \bullet}$ & 48 & 1,50 & 0,255 & & & & \\
\hline & $\mathrm{PR}^{\bullet}$ & 9 & 1,00 & 0,000 & & & & \\
\hline Ají \# 286 & $\mathrm{PR} \bullet$ & 50 & 1,00 & 0,000 & & & & \\
\hline & $\mathrm{PR}^{\bullet}$ & 9 & 1,00 & 0,000 & & & & \\
\hline BGH 2994 & $\mathrm{PR}^{\bullet \bullet}$ & 20 & 1,00 & 0,000 & & & & \\
\hline & $\mathrm{PS}^{\bullet}$ & 9 & 4,00 & 0,000 & & & & \\
\hline Ají \# 263 & $\mathrm{PS}^{\bullet \bullet}$ & 60 & 4,42 & 0,247 & & & & \\
\hline & $\mathrm{PS}^{\bullet}$ & 9 & 2,78 & 0,194 & & & & \\
\hline Ají Amarillo \# 269 & PS •• & 40 & 3,37 & 0,240 & & & & \\
\hline & $\mathrm{PS}^{\bullet}$ & 9 & 2,55 & 0,278 & & & & \\
\hline Pimenta & $\mathrm{PS}^{\bullet \bullet}$ & 48 & 3,52 & 0,255 & & & & \\
\hline & $\mathrm{TS}^{\bullet}$ & 9 & 5,00 & 0,000 & & & & \\
\hline Magali R & $\mathrm{TS}^{\bullet \bullet}$ & 40 & 5,00 & 0,000 & & & & \\
\hline & $\mathrm{TS}^{\bullet}$ & 9 & 5,00 & 0,000 & & & & \\
\hline Margarita & $\mathrm{TS}^{\bullet \bullet}$ & 40 & 5,00 & 0,000 & & & & \\
\hline & $\mathrm{F}_{1}^{\bullet}$ & 9 & 2,44 & 0,278 & & & & \\
\hline Ají \# 263 x Ch. de & $\mathrm{F}_{1} \bullet \bullet$ & 57 & 2,47 & 0,254 & & & & \\
\hline Bispo & $\mathrm{F}_{2} \bullet \bullet$ & 518 & 2,50 & 1,256 & $\geq 2$ & 2 & 79,90 & $-30,0^{\boldsymbol{\Lambda}}$ \\
\hline & $\mathrm{F}_{1}^{\bullet}$ & 9 & 2,00 & 0,000 & & & & \\
\hline Ají \# $286 \times$ x Ají \# & $\mathrm{F}_{1} \bullet$ & 25 & 1,36 & 0,240 & & & & \\
\hline 263 & $\mathrm{~F}_{2} \bullet \bullet$ & 574 & 1,53 & 0,487 & $\geq 4$ & 6 & 62,63 & $-7,2^{\mathbf{\Lambda}}$ \\
\hline & $\mathrm{RCPR}^{\bullet \bullet}$ & 56 & 1,07 & 0,067 & & & & \\
\hline & $\mathrm{F}_{1}^{\bullet}$ & 9 & 3,00 & 0,000 & & & & \\
\hline Ají Amarillo \# 269 & $\mathrm{~F}_{1} \bullet \bullet$ & 45 & 2,37 & 0,240 & & & & \\
\hline x Ch. de Bispo & $\mathrm{F}_{2} \bullet \bullet$ & 600 & 2,33 & 0,815 & & & 70,06 & $-19,3$ \\
\hline & $\mathrm{F}_{1}^{\bullet}$ & 9 & 3,33 & 0,500 & & & & \\
\hline Pimenta x Chapéu & $\mathrm{F}_{1} \bullet \bullet$ & 60 & 2,33 & 0,328 & & & & \\
\hline de Bispo & $\mathrm{F}_{2} \bullet \bullet$ & 590 & 2,04 & 0,601 & & & 51,58 & $-10,3^{\boldsymbol{\Lambda}}$ \\
\hline & $\mathrm{F}_{1}^{\bullet}$ & 9 & 1,33 & 0,250 & & & & \\
\hline Ají \# $263 \times$ BGH & $\mathrm{F}_{1} \bullet \bullet$ & 60 & 1,07 & 0,063 & & & & \\
\hline 2994 & $\mathrm{~F}_{2} \bullet \bullet$ & 577 & 1,45 & 0,484 & $\geq 3$ & 5 & 80,78 & $-7,6^{\mathbf{\Lambda}}$ \\
\hline
\end{tabular}

•Resultados obtidos em fevereiro de 2002 (primeira avaliação) - na obtenção da geração $F_{1}$.

- Resultados obtidos em setembro de 2002 (segunda avaliação) - na obtenção da geração $F_{2}$.

$\triangle$ Ganho de seleção superestimado, calculado em função de $\mathrm{h}^{2}$ no sentido amplo.

1. PR - Progenitor resistente, PS - progenitor suscetível, RC PR - retrocruzamento, TS Testemunha suscetível 
Tabela 11. Estimativas dos valores da heterose ( $\mathrm{H} \mathrm{e} \mathrm{H} \%)$ e de efeitos da epistasia (C) com significância pelo teste t. C. baccatum. 2003

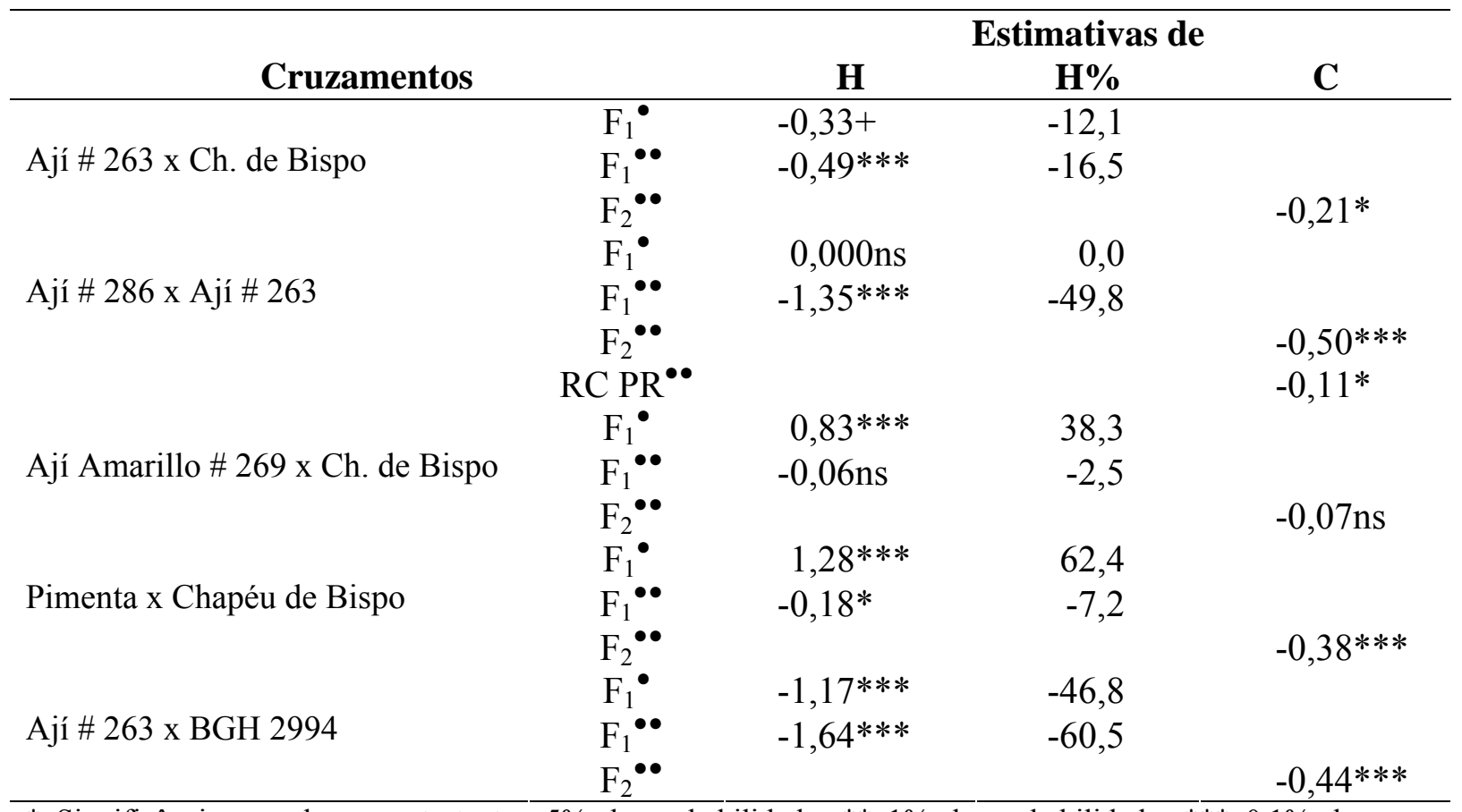

* Significância com base no teste $\mathrm{t}$ a $5 \%$ de probabilidade; $* * 1 \%$ de probabilidade; $* * * 0,1 \%$ de probabilidade; + entre e $5 \%$ e $10 \%$ de probabilidade; ns- não significativo.

-Resultados obtidos em fevereiro de 2002 (primeira avaliação) - na obtenção da geração $F_{1}$.

• Resultados obtidos em setembro de 2002 (segunda avaliação) - na obtenção da geração $F_{2}$. 

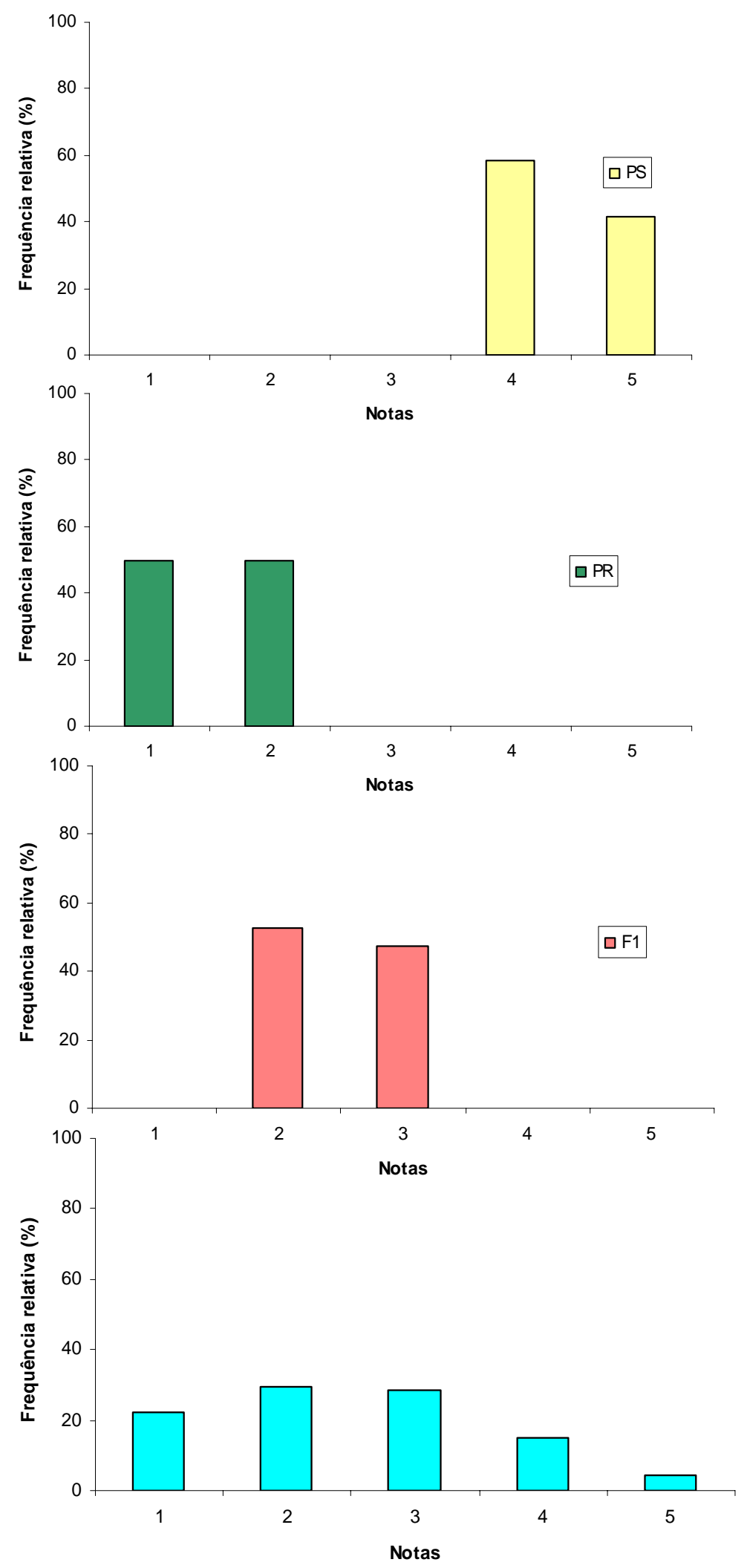

Figura 2 - Histograma de distribuição de freqüência do número de plantas em cada classe de notas nas gerações $P_{R}, P_{S}, F_{1}, F_{2}$ para o cruzamento Ají \# 263 x Chapéu de Bispo. Capsicum baccatum. 2003 

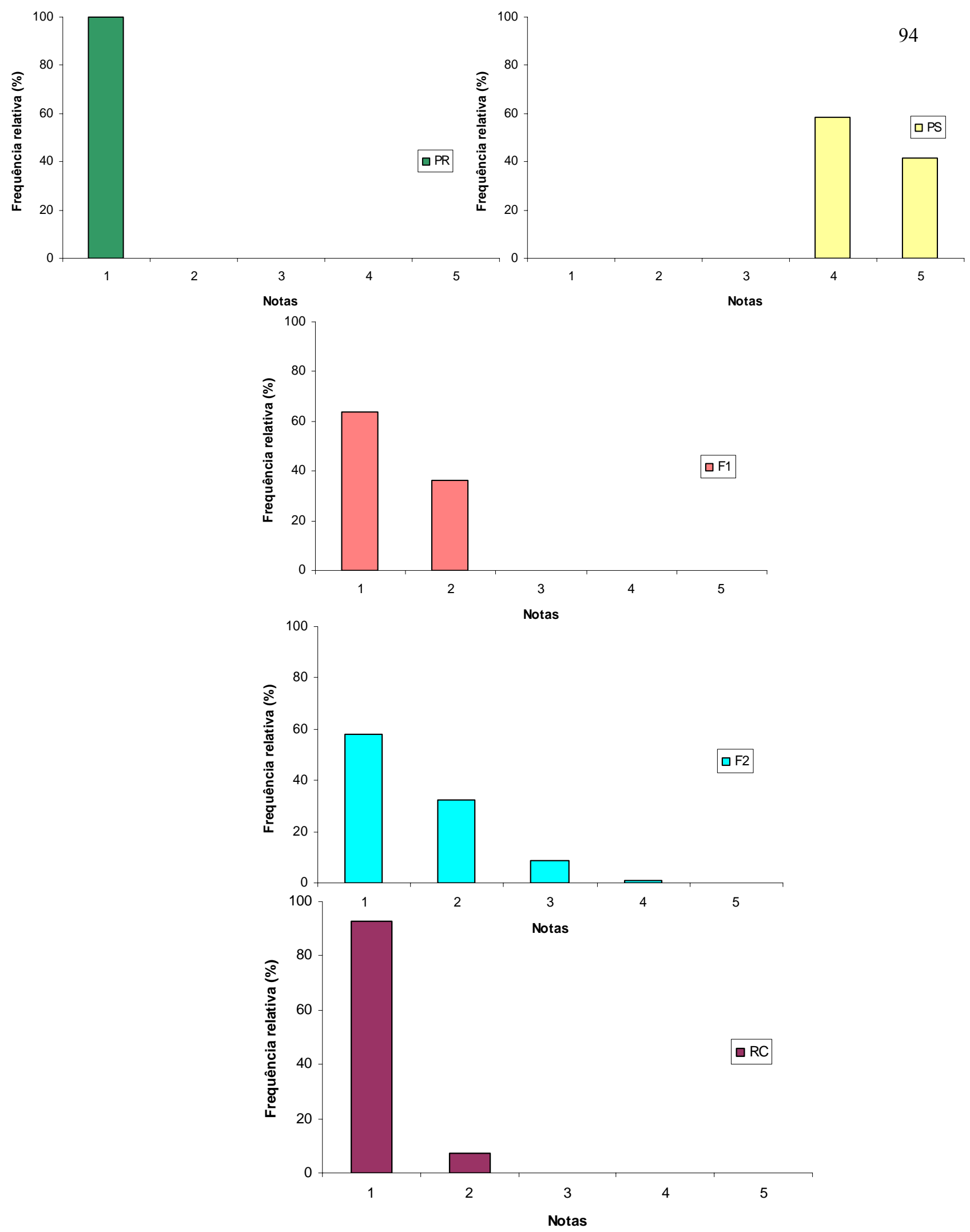

Figura 3 - Histograma de distribuição de freqüência do número de plantas em cada classe de notas nas gerações $P_{R}, P_{S}, F_{1}, F_{2}$ e retrocruzamento para $o$ cruzamento Ají \# 286 x Ají \# 263. Capsicum baccatum. 2003 

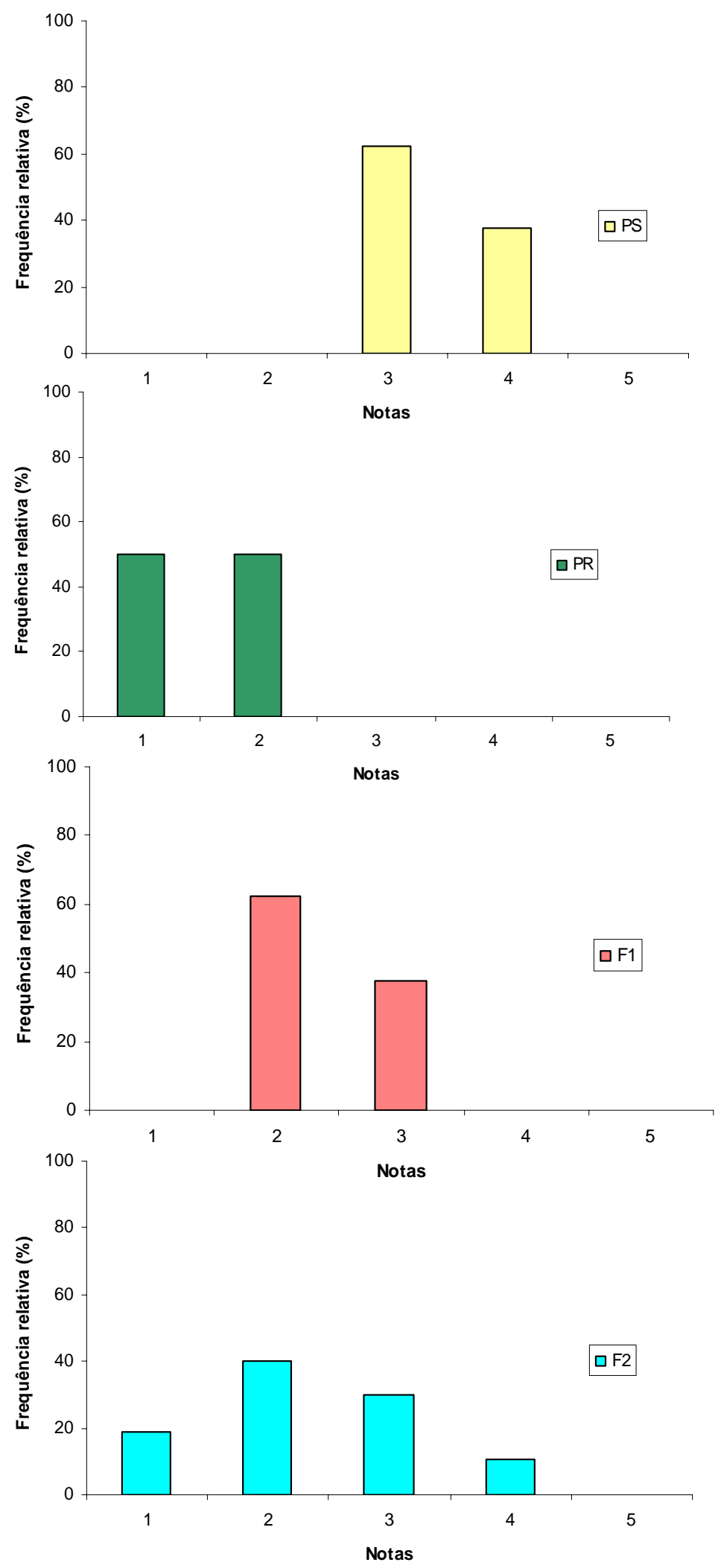

Figura 4 - Histograma de distribuição de freqüência do número de plantas em cada classe de notas nas gerações $\mathrm{P}_{\mathrm{R}}, \mathrm{P}_{\mathrm{S}}, \mathrm{F}_{1}, \mathrm{~F}_{2}$ para o cruzamento Ají Amarillo \# 269 x Chapéu de Bispo. Capsicum baccatum. 2003 

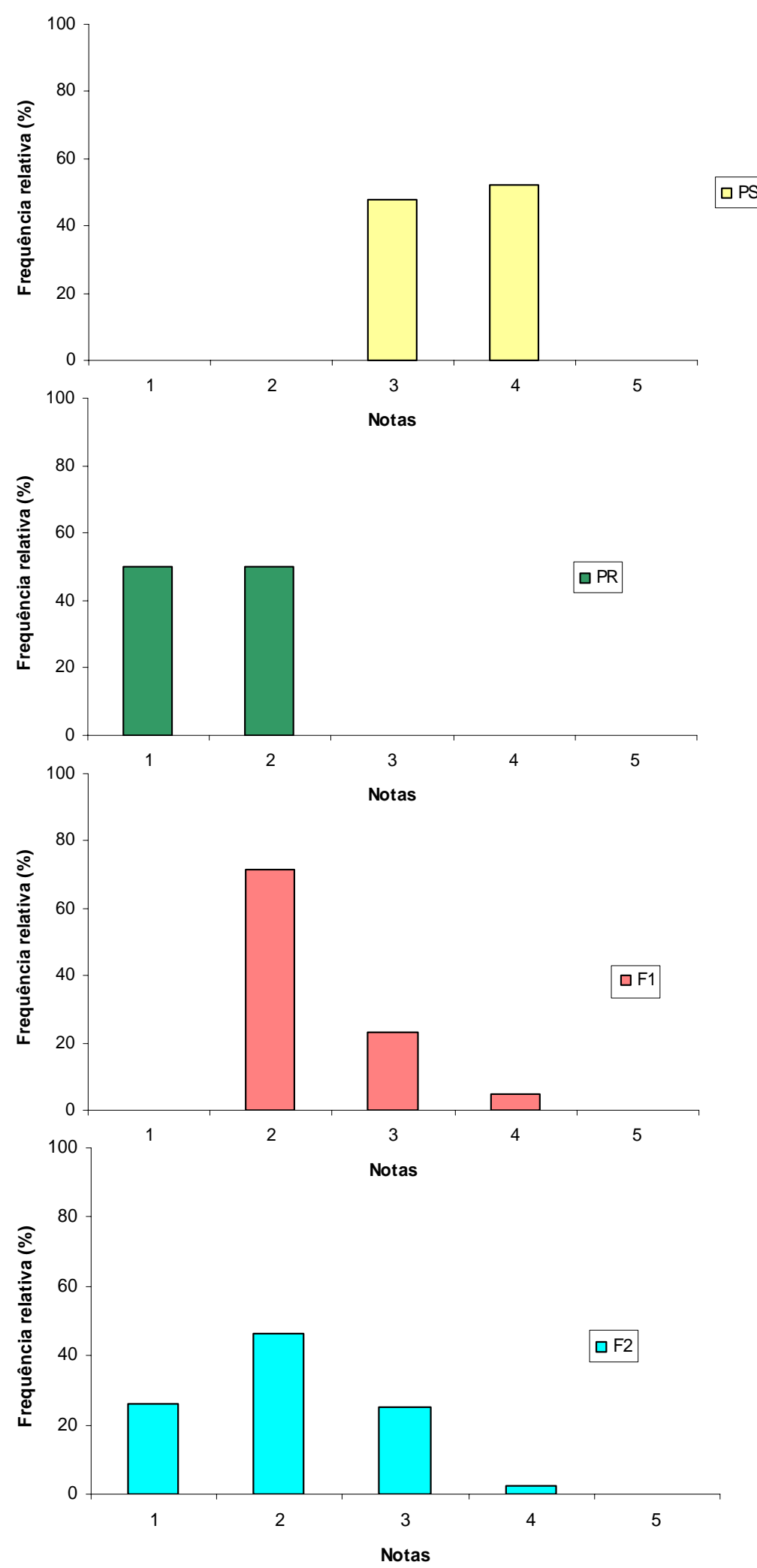

Figura 5 - Histograma de distribuição de freqüência do número de plantas em cada classe de notas nas gerações $\mathrm{P}_{\mathrm{R}}, \mathrm{P}_{\mathrm{S}}, \mathrm{F}_{1}, \mathrm{~F}_{2}$ para o cruzamento Pimenta $\mathrm{x}$ Chapéu de Bispo. Capsicum baccatum. 2003 


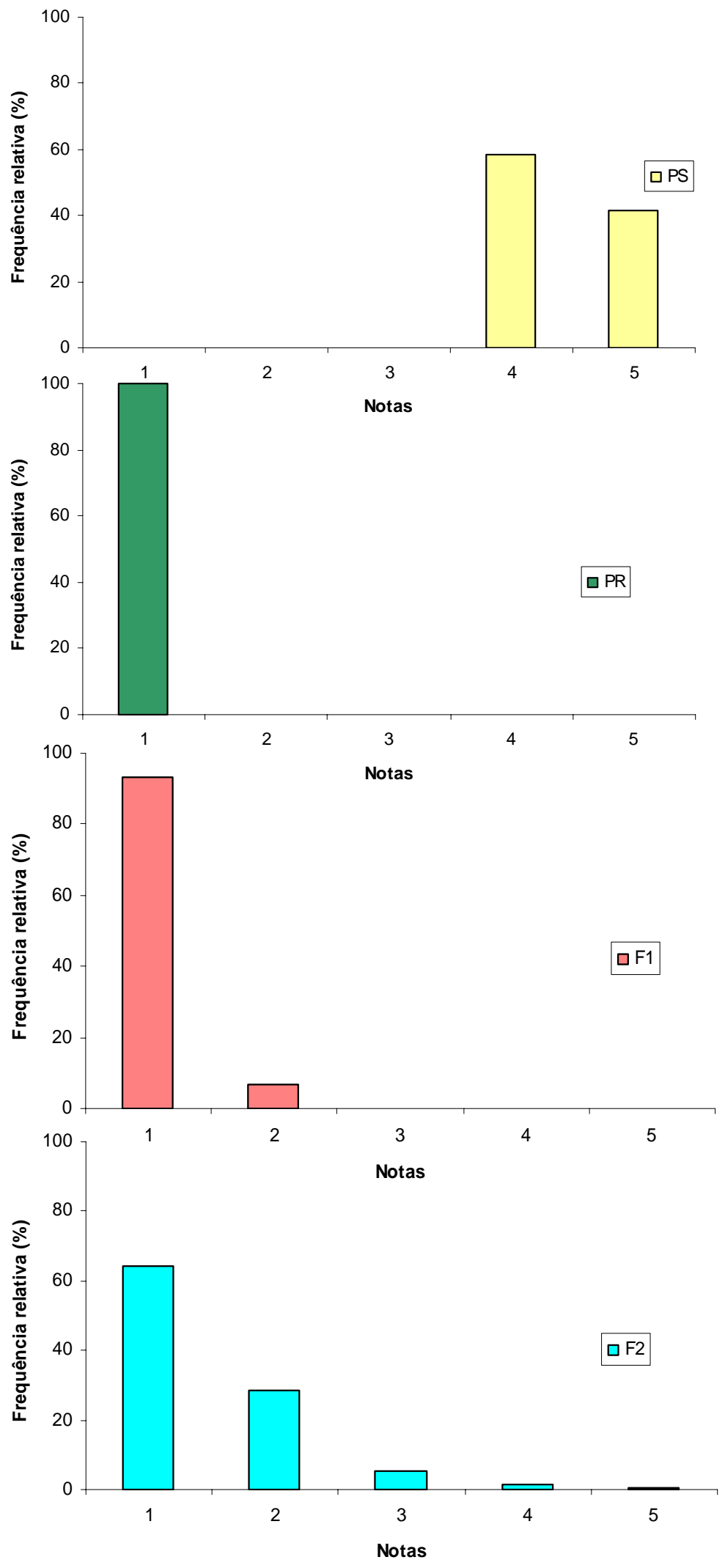




\subsubsection{Reação de híbridos obtidos de cruzamentos entre progenitores resistentes}

A reação ao oídio apresentada pela espécie C. baccatum, tem uma característica fenológica muito diferenciada de C. annuum. Ocorreu uma intensa defoliação em conseqüência da reação de hipersensibilidade (descrita no item 4.3.1). Uma grande parte dos acessos resistentes dessa espécie, na presença das linhas espalhadoras, ou seja, em condições de alta pressão de inóculo, apresentaram pequenas lesões necróticas que coalesceram e posteriormente causaram queda das folhas. Esse sintoma de defoliação também foi observado por Lima (2002) nesta espécie. Todos os progenitores apresentaram variações de graus de resistência entre as notas 1 e 2 (Tabelas 12 e 13).

O mecanismo de resistência dessa espécie não é similar ao da fonte HV-12 de $C$. annuum L, que além de não permitir a penetração do patógeno, não ocorre defoliação. Segundo Tokeshi ${ }^{2}$, o tipo de reação apresentado pela espécie C. baccatum é tipicamente relacionada com resistência horizontal. De acordo com Van Der Plank (1968), a resistência horizontal é governada por muitos genes, cada qual apresentando um pequeno efeito, retardando e diminuindo o progresso da doença.

Observou-se pelos resultados nas reações dos progenitores e híbridos que a severidade do oídio na segunda avaliação foi menor que na primeira avaliação (Tabela 13). Essas diferenças podem ser explicadas pelos efeitos ambientais em cada época de avaliação e diferenças nas pressões de inóculo, sendo maior na primeira avaliação.

Apesar das médias da geração $F_{1}$ apresentarem-se ligeiramente superiores às médias dos seus respectivos progenitores, ocasionando uma heterose de efeito positivo, essa não foi significativa, indicando que os efeitos de dominância não se manifestaram para estes cruzamentos. $\mathrm{O}$ mesmo ocorreu na geração $\mathrm{F}_{2}$, apesar da média observada ter sido maior que a esperada, levando a um valor de epistasia positivo, também não se detectou significância (Tabela 13). Assim esses resultados indicam que essa maior severidade foi de efeito ambiental e não genético.

O fato de a dominância e epistasia não terem se manifestado nos cruzamentos entre acessos resistentes, evidencia que a herança que governa a resistência em $C$. baccatum não é tão complexa e indica maior similaridade genética dos progenitores.

${ }^{2}$ TOKESHI, H. Comunicação pessoal, 2003. 
O uso de híbridos de pimenta nas espécies $C$. baccatum e $C$. chinense ainda não é uma prática explorada como no caso de C. annuum. A qualidade de frutos de pimenta não depende do seu tamanho e formato, o que facilita e viabiliza o uso de híbridos, associando resistência ao oídio com outras resistências à patógenos. O segmento de pimenta baseado em C. baccatum e C. chinense é restrito só para a América do Sul. No restante do mundo, como Índia, Coréia, México e EUA, este segmento é dominado preferencialmente por variedades e híbridos de C. annuum, sendo essas todas suscetíveis ao oídio. Portanto o fato de ter sido encontrado um grande número de acessos e híbridos em C. baccatum com resistência ao oídio, evidencia a possibilidade de se desenvolver pimentas resistentes ao oídio em curto prazo. 
Tabela 12. Número de plantas em cada classe, de acordo com a escala de notas para resistência a Leveillula taurica em condições de casa de vegetação. C. baccatum. 2003

\begin{tabular}{|c|c|c|c|c|c|c|}
\hline Gerações $^{1}$ & & $\begin{array}{c}\mathbf{R} \\
\text { Nota } 1 \\
\end{array}$ & $\begin{array}{c}\text { MR } \\
\text { Nota } 2 \\
\end{array}$ & $\begin{array}{c}\text { MS } \\
\text { Nota } 3 \\
\end{array}$ & $\begin{array}{c}\text { S } \\
\text { Nota } 4\end{array}$ & $\begin{array}{c}\text { AS } \\
\text { Nota } 5\end{array}$ \\
\hline & $\mathrm{PR}^{\bullet}$ & 1 & 8 & 0 & 0 & 0 \\
\hline \multirow[t]{2}{*}{ Aji \# 284} & $\mathrm{PR}^{\bullet \bullet}$ & 8 & 34 & 0 & 0 & 0 \\
\hline & $\mathrm{PR}^{\bullet}$ & 4 & 5 & 0 & 0 & 0 \\
\hline \multirow[t]{2}{*}{ Chapéu de Bispo } & $\mathrm{PR}^{\bullet \bullet}$ & 24 & 24 & 0 & 0 & 0 \\
\hline & $\mathrm{PR}^{\bullet}$ & 9 & 0 & 0 & 0 & 0 \\
\hline \multirow[t]{2}{*}{ Aji Amarillo \#267 } & $\mathrm{PR}^{\bullet \bullet}$ & 41 & 5 & 0 & 0 & 0 \\
\hline & $\mathrm{PR}^{\bullet}$ & 2 & 7 & 0 & 0 & 0 \\
\hline \multirow[t]{2}{*}{ BGH 0620} & $\mathrm{PR}^{\bullet \bullet}$ & 17 & 29 & 10 & 0 & 0 \\
\hline & $\mathrm{TS}^{\bullet}$ & 0 & 0 & 0 & 0 & 9 \\
\hline \multirow[t]{2}{*}{ Magali R } & $\mathrm{TS}^{\bullet \bullet}$ & 0 & 0 & 0 & 0 & 40 \\
\hline & $\mathrm{TS}^{\bullet}$ & 0 & 0 & 0 & 0 & 9 \\
\hline \multirow[t]{2}{*}{ Margarita } & $\mathrm{TS}^{\bullet \bullet}$ & 0 & 0 & 0 & 0 & 40 \\
\hline & $\mathrm{F}_{1}^{\bullet}$ & 0 & 7 & 2 & 0 & 0 \\
\hline \multirow[t]{3}{*}{ Aji \# 284 x Ch. de Bispo } & $\mathrm{F}_{1}^{\bullet \bullet}$ & 10 & 19 & 1 & 0 & 0 \\
\hline & $\mathrm{F}_{2}^{\bullet \bullet}$ & 197 & 290 & 70 & 3 & 0 \\
\hline & $\mathrm{F}_{1}^{\bullet}$ & 4 & 5 & 0 & 0 & 0 \\
\hline \multirow[t]{3}{*}{ Aji Amarillo \#267 x Ch. de Bispo } & $\mathrm{F}_{1}^{\bullet \bullet}$ & 33 & 20 & 0 & 0 & 0 \\
\hline & $\mathrm{F}_{2}^{\bullet \bullet}$ & 373 & 170 & 43 & 0 & 0 \\
\hline & $\mathrm{F}_{1}^{\bullet}$ & 1 & 8 & 0 & 0 & 0 \\
\hline \multirow{2}{*}{ BGH 0620 x Chapéu de Bispo } & $\mathrm{F}_{1}^{\bullet \bullet}$ & 16 & 42 & 1 & 0 & 0 \\
\hline & $\mathrm{F}_{2}^{\bullet \bullet}$ & 220 & 266 & 95 & 7 & 0 \\
\hline
\end{tabular}

-Resultados obtidos em fevereiro de 2002 (primeira avaliação) - na obtenção da geração $F_{1}$.

• Resultados obtidos em setembro de 2002 (segunda avaliação) - na obtenção da geração $\mathrm{F}_{2}$.

1. $\quad$ PR - Progenitor resistente, TS - Testemunha suscetível. 
Tabela 13. Número total de plantas (n), estimativas de médias, variâncias, valores da heterose (H e H\%) e epistasia (C) com significância pelo teste t. C.baccatum, 2003

\begin{tabular}{|c|c|c|c|c|c|c|c|}
\hline Gerações $^{1}$ & & $\mathbf{n}$ & Médias & Variâncias & $\mathbf{H}$ & H\% & C \\
\hline \multirow{3}{*}{ Aji \# 284} & $\mathrm{PR}^{\bullet}$ & 9 & 1,87 & 0,111 & & & \\
\hline & $\mathrm{PR}^{\bullet \bullet}$ & 42 & 1,81 & 0,158 & & & \\
\hline & $\mathrm{PR}^{\bullet}$ & 9 & 1,55 & 0,278 & & & \\
\hline \multirow[t]{2}{*}{ Chapéu de Bispo } & $\mathrm{PR}^{\bullet \bullet}$ & 48 & 1,50 & 0,255 & & & \\
\hline & $\mathrm{PR}^{\bullet}$ & 9 & 1,00 & 0,000 & & & \\
\hline \multirow[t]{2}{*}{ Aji Amarillo \#267 } & $\mathrm{PR}^{\bullet \bullet}$ & 46 & 1,11 & 0,099 & & & \\
\hline & $\mathrm{PR}^{\bullet}$ & 9 & 1,78 & 0,194 & & & \\
\hline \multirow[t]{2}{*}{ BGH 0620} & $\mathrm{PR}^{\bullet \bullet}$ & 56 & 1,87 & 0,475 & & & \\
\hline & $\mathrm{TS}^{\bullet}$ & 9 & 5,00 & 0,000 & & & \\
\hline \multirow[t]{2}{*}{ Magali R } & $\mathrm{TS}^{\bullet \bullet}$ & 40 & 5,00 & 0,000 & & & \\
\hline & $\mathrm{TS}^{\bullet}$ & 9 & 5,00 & 0,000 & & & \\
\hline \multirow[t]{2}{*}{ Margarita } & $\mathrm{TS}^{\bullet \bullet}$ & 40 & 5,00 & 0,000 & & & \\
\hline & $\mathrm{F}_{1}^{\bullet}$ & 9 & 2,22 & 0,194 & $0,50^{*}$ & 29,07 & \\
\hline \multirow{3}{*}{$\begin{array}{l}\text { Aji \# } 284 \text { x Chapéu } \\
\text { de Bispo }\end{array}$} & $\mathrm{F}_{1}^{\bullet \bullet}$ & 30 & 1,70 & 0,286 & $0,05 \mathrm{~ns}$ & 3,03 & \multirow{3}{*}{$0,10 \mathrm{~ns}$} \\
\hline & $\mathrm{F}_{2}^{\bullet \bullet}$ & 560 & 1,78 & 0,452 & & & \\
\hline & $\mathrm{F}_{1}^{\bullet}$ & 9 & 1,55 & 0,278 & $0,27 \mathrm{~ns}$ & 21,18 & \\
\hline \multirow{3}{*}{$\begin{array}{l}\text { Aji Amarillo \#267 x } \\
\text { Ch. de Bispo }\end{array}$} & $\mathrm{F}_{1} \bullet \bullet$ & 53 & 1,38 & 0,239 & $0,07 \mathrm{~ns}$ & 5,38 & \multirow{3}{*}{$0,09 \mathrm{~ns}$} \\
\hline & $\mathrm{F}_{2}^{\bullet \bullet}$ & 586 & 1,43 & 0,393 & & & \\
\hline & $\mathrm{F}_{1}^{\bullet}$ & 9 & 1,89 & 0,111 & $0,22 \mathrm{~ns}$ & 13,21 & \\
\hline \multirow{2}{*}{$\begin{array}{l}\text { BGH } 0620 \text { x Chapéu } \\
\text { de Bispo }\end{array}$} & $\mathrm{F}_{1}^{\bullet \bullet}$ & 59 & 1,75 & 0,227 & $0,07 \mathrm{~ns}$ & 4,17 & \multirow[b]{2}{*}{$0,09 \mathrm{~ns}$} \\
\hline & $\mathrm{F}_{2} \bullet \bullet$ & 588 & 1,81 & 0,549 & & & \\
\hline
\end{tabular}

* Significância com base no teste t a $5 \%$ de probabilidade; ns- não significativo.

- Resultados obtidos em fevereiro de 2002 (primeira avaliação) - na obtenção da geração $\mathrm{F}_{1}$.

- Resultados obtidos em setembro de 2002 (segunda avaliação) - na obtenção da geração $F_{2}$.

1. $\quad$ PR - Progenitor resistente, TS - Testemunha suscetível. 

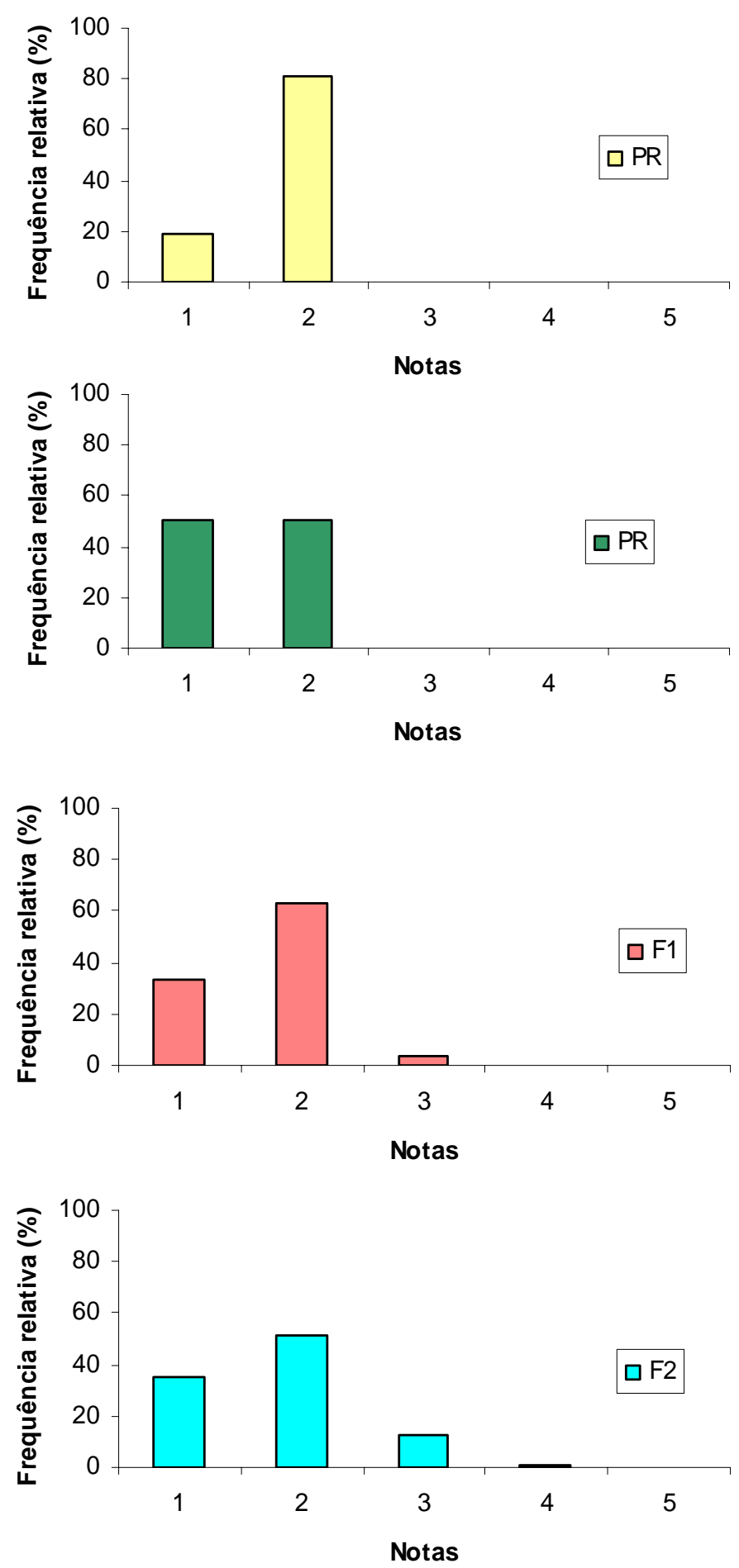

Figura 7 - Histograma de distribuição de freqüência do número de plantas em cada classe de notas nas gerações $\mathrm{P}_{\mathrm{R}}, \mathrm{P}_{\mathrm{R}}, \mathrm{F}_{1}, \mathrm{~F}_{2}$ para o cruzamento Aji \# $284 \mathrm{x}$ Chapéu de Bispo. Capsicum baccatum. 2003 

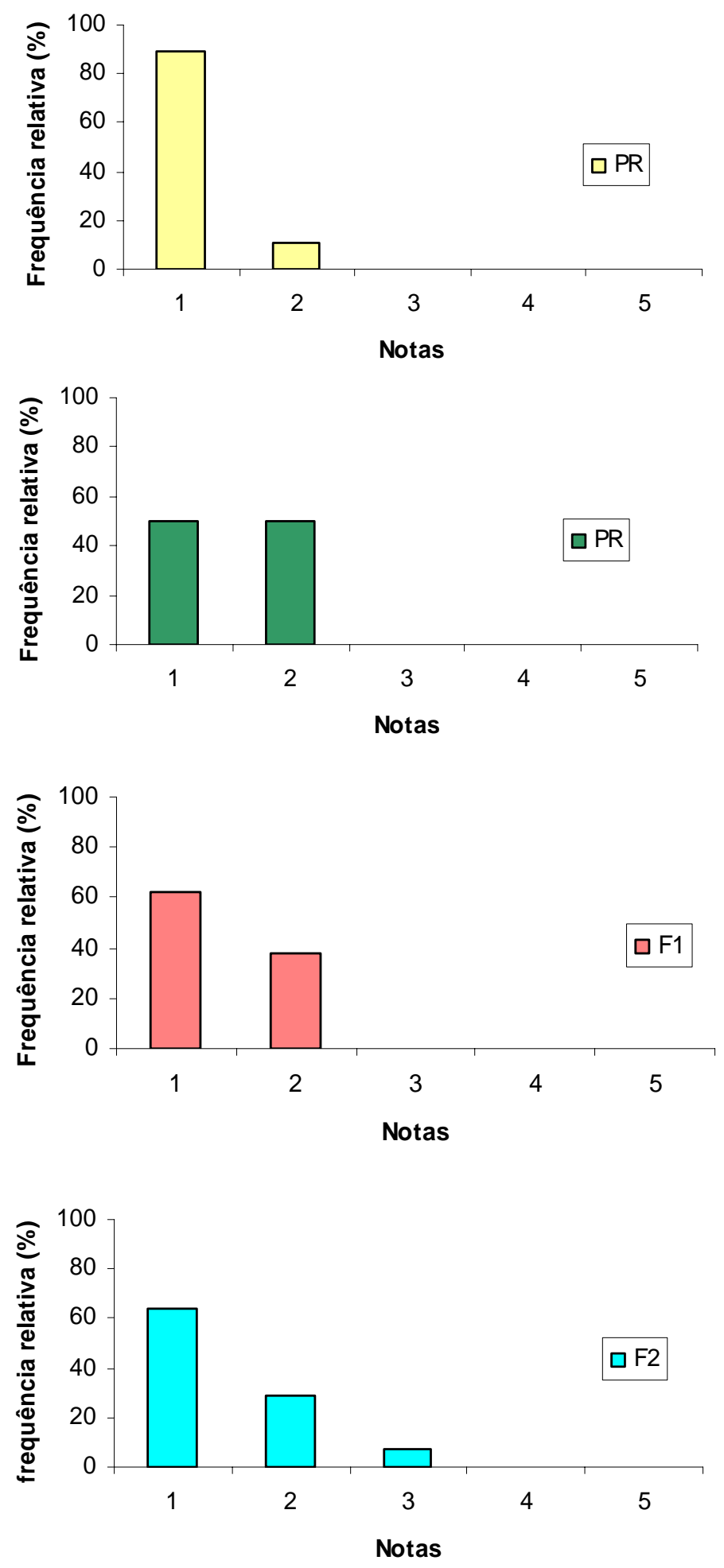

Figura 8 - Histograma de distribuição de freqüência do número de plantas em cada classe de notas nas gerações $\mathrm{P}_{\mathrm{R}}, \mathrm{P}_{\mathrm{R}}, \mathrm{F}_{1}, \mathrm{~F}_{2}$ para o cruzamento Aji Amarillo \#267 x Chapéu de Bispo Capsicum baccatum. 2003 

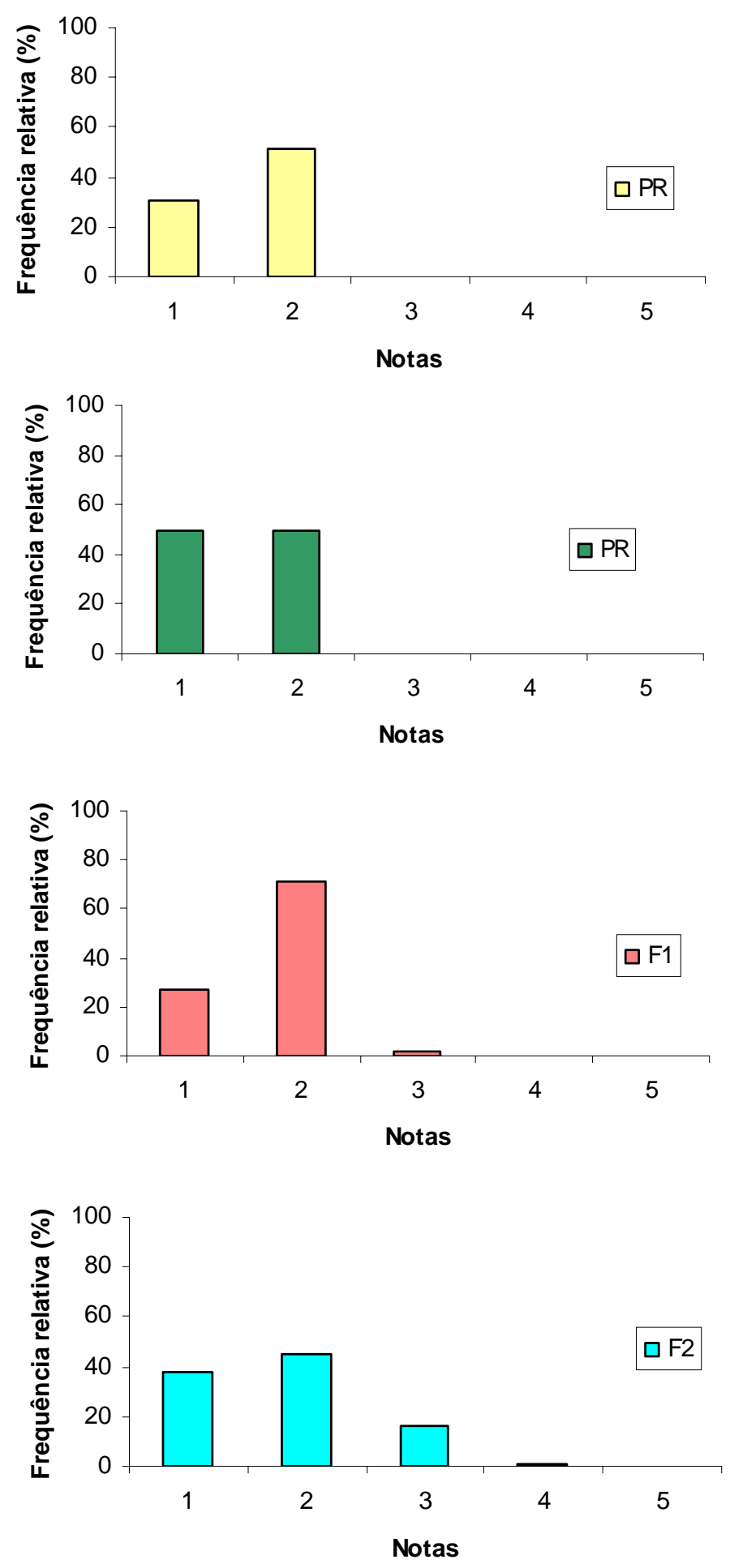

Figura 9 - Histograma de distribuição de freqüência do número de plantas em cada classe de notas nas gerações $\mathrm{P}_{\mathrm{R}}, \mathrm{P}_{\mathrm{R}}, \mathrm{F}_{1}, \mathrm{~F}_{2}$ para o cruzamento $\mathrm{BGH} 0620 \mathrm{x}$ Chapéu de Bispo Capsicum baccatum. 2003 


\subsection{Conclusões}

- Dentre os acessos triados, $84 \%$ foram resistentes ao oídio.

- A queda foliar, como resultado de uma reação de hipersensibilidade ao fungo ocorreu em quase todos os acessos.

- A resistência mostrou-se dominante em todas as gerações $\left(F_{1}\right.$ e $\left.F_{2}\right)$ de cada cruzamento. As variâncias genéticas aditivas, dominante e epistáticas manifestaram-se para todos os cruzamentos com exceção de Aji Amarillo \# 269 x Chapéu de Bispo, no qual somente a ação aditiva ocorreu.

- A herança da resistência ao oídio mostrou ser controlada por no mínimo de 2 a 6 pares de genes segregantes.

- Os valores de herdabilidade foram altos, acima de 50\% em todos os cruzamentos, indicando que o desenvolvimento de variedades resistentes ao oídio em C. baccatum é promissor.

- Tanto as reações de resistência quanto os mecanismos de resistência dos progenitores são similares, não indicando diferenças alélicas. 


\title{
5 HERANÇA DA REAÇÃO DE Capsicum chinense AO OÍDIO
}

\author{
Autora: SALLY FERREIRA BLAT \\ Orientador: Prof. Dr. CYRO PAULINO DA COSTA
}

\section{Resumo}

As espécies C. chinense e C. baccatum tem sido consideradas as melhores fontes de resistência ao oídio, porém a herança dessa resistência não tem sido estudada nessas espécies. O objetivo deste trabalho foi triar os acessos da coleção de C. chinense da ESALQ/USP, identificando as fontes de resistência e obter informações sobre a herança dessa reação. Um total de 20 acessos de $C$. chinense foi avaliado quanto a suas reações ao oídio. A partir dessas reações seis híbridos foram obtidos sendo três realizados a partir de acessos resistentes versus suscetíveis e os outros três entre quatro acessos resistentes. As gerações $\mathrm{F}_{2}$ também foram avaliadas. As avaliações das reações ao oídio foram feitas na época da frutificação, através de uma escala de notas de acordo com a severidade da doença de 1 (resistente) a 5 (altamente suscetível). A partir das reações obtiveram-se: estimativas do número de locos segregantes, dos coeficientes de herdabilidade, dos progressos esperados com a seleção, o tipo de ação gênica envolvida e avaliadas as reações dos híbridos entre progenitores resistentes. Dentre os materiais triados $85 \%$ foram considerados resistentes. A segregação transgressiva em $\mathrm{F}_{2}$ indicou que a herança é poligênica e o tipo de ação gênica envolveu os componentes aditivos, dominantes e epistáticos. A dominância e epistasia detectadas nos cruzamentos se mostraram negativas, a favor da resistência. As reações dos híbridos e das gerações $F_{2} \mathrm{e}$ a análise genética dos cruzamentos entre progenitores resistentes mostraram a similaridade genética dos progenitores, não indicando diferenças alélicas. 


\title{
INHERITANCE REACTION IN Capsicum chinense TO POWDERY MILDEW
}

\author{
Author: SALLY FERREIRA BLAT \\ Adviser: Prof. Dr. CYRO PAULINO DA COSTA
}

\section{Summary}

The species Capsicum chinense and C. baccatum has been the best sources of resistance to powdery mildew, but their resistance inheritance is unknown. The present work aimed to screen 20 C. chinense the ESALQ/USP Capsicum collection, to identify resistant sources and to elucidate the powdery mildew inheritance reaction for this species. Six hybrids were obtained, three between resistant and susceptible accesses and three from among four resistant parental crosses. $F_{2}$ generations and one backcross was obtained. Reaction evaluations to powdery mildew were carried out during the fruit production using a rating system based on score disease severity using scale varying from 1 (resistant) to 5 (highly susceptible). Estimations of segregating loci number, heritability and expected selection gains was made, to investigate the gene action and to evaluate hybrid powdery mildew reaction obtained from crossing between resistant progenitors. Eighty-five percent of the evaluated accesses were considered resistant. The transgressive segregation in $\mathrm{F}_{2}$ indicated polygenic inheritance and additive, dominant and epistatic gene action. Reactions to powdery mildew of hybrids resistant versus resistant and their respectively $\mathrm{F}_{2}$ showed genetic similarities with no allelic difference.

\subsection{Introdução}

O Brasil é considerado um importante centro secundário e de diversidade das espécies domesticadas de pimenta Capsicum annuum, C. baccatum e C. frutescens. Estas teriam sido introduzidas no país a partir dos centros de diversidade andinos e o processo seletivo criou novos tipos morfológicos diferentes daqueles encontrados nas áreas originais. Em relação a espécies C. chinense a história é diferente. C. chinense é provavelmente, a mais importante espécie cultivada ao Leste dos Andes. A área de maior diversidade é a bacia Amazônica. Desse fato pode-se concluir que foi domesticada 
pelos indígenas amazônicos e, portanto, trata-se da mais brasileira dentre as espécies domesticadas. Possui flores brancas esverdeadas sem manchas difusas na base das pétalas da corola. É morfologicamente similar a espécies C. frutescens. Encontra-se distribuída pela América Central, Caribe e região central da América do Sul e tem seu centro de maior diversidade na região Amazônica. Ocorre também no Peru e Bolívia se sobrepondo aos limites geográficos de C. annuum e C. baccatum (Nuez, 1996, Bertão, 1993).

Dentro da espécie $C$. chinense os tipos mais consumidos são a pimenta de cheiro e pimenta de bode. A pimenta de cheiro é encontrada em tons amarelo-leitoso, amareloclaro, amarelo forte, alaranjado, salmão, vermelho, até preto e predomina no nordeste, norte e centro-oeste do Brasil. Na região sudeste é mais comum o cultivo da pimenta de bode, cujas plantas produzem frutos arredondados com cerca de $1 \mathrm{~cm}$ de diâmetro, e as cores creme e vermelho dos frutos maduros são as mais comuns. Tanto a pimenta de cheiro quanto a de bode possuem pungência e um aroma característico que permite sua diferenciação das demais pimentas, sendo a razão da preferência dos consumidores que a apreciam.

No Brasil a área plantada de pimenta e pimentão chega a 12.000 ha. O volume comercializado do ano de 1998 no CEASA-MG foi de $170.785 \mathrm{~kg}$, sendo $300 \mathrm{~kg}$ de procedência do estado do Espírito Santo, 168.000 de Minas Gerais e 2.485 de São Paulo (FAO, 1999).

Atualmente uma das mais preocupantes e importantes doenças do gênero Capsicum é o oídio, causado pelo fungo Leveillula taurica e segundo a literatura as melhores fontes de resistência se encontram nas espécies $C$. chinense e C. baccatum (Bidari, 1985; Anand et al., 1987; Souza, 2000, Blat, 2002 e Lima, 2002). Segundo Reifschneider et al. (2000), por serem espécies menos trabalhadas pelo homem seus genes que conferem resistência foram mantidos durante o processo de domesticação.

Zewdie (1994), avaliaram 44 linhagens para incidência de oídio (0-100\%). A incidência de oídio foi severa na maioria das linhagens. O registro da doença apareceu nas linhagens PBC376, PBC210, PBC233, PBC266, PBC270, PBC374 e PBC378 e as folhas colonizadas pelo patógeno caíram após alguns dias. A linhagem PBC376 mostrou 
maior tolerância em produção do que o padrão suscetível. Os acessos PBC151 e PBC171, pertencentes à espécie Capsicum baccatum e C. chinense, mostraram alto nível de resistência em condições de campo.

Daubeze et al. (1995) avaliando acessos de Capsicum quanto as suas reações ao oídio identificaram resistência parcial ao oídio em condições de campo nos acessos 'PM 803' (C. chinense), 'PEN 26' (C. baccatum) e particularmente nos acessos 'PI 322719' e 'H3' (C. annuum).

Souza (2000), avaliou a reação de acessos de Capsicum do Banco de germoplasma da Embrapa hotaliças a L. taurica. Identificaram-se oito acessos imunes: HV12, 4638 e pimentas como ABE (CNPH 36), Kurimoto (CNPH 38), Nélio redonda (CNPH 50), Nélio fina 2 (CNPH 52), Escabeche (CNPH 279) e Malagueta (CNPH 288). A maioria dos acessos de C. baccatum, C. frutescens e C. chinense foi resistente.

Lima (2002) avaliando a reação de acessos de Capsicum ao oídio em telado e casa de vegetação verificou que as espécies C. baccatum, C. chinense e C. frutescens foram pouco variáveis quanto a sua morfologia e apresentaram a maior proporção de acessos resistentes ao oídio, sendo assim indicadas na busca de fontes de resistência ao oídio. Em C. chinense, nenhum acesso foi considerado suscetível, o acesso Pimenta peixe-deboi (CNPH 434) foi altamente resistente, os acessos Pimenta Olho de Ganso (CNPH 289), Pimenta de Cheiro (CNPH 55), Pimenta do Maranhão (CNPH 436), Pimenta do Maranhão (CNPH 503) e Pimenta Picante (CNPH 573) foram resistentes e os acessos Pimenta de Cheiro (CNPH 600) e Pimenta (CNPH 670) foram moderadamente resistentes.

A reação de resistência ao oídio na espécie $C$. chinense tem sido estudada e mostra grande potencial a ser explorado, porém o modo de herança dessa reação é ainda desconhecido. A coleção de C. chinense da ESALQ/USP foi triada identificando-se os acessos resistentes e suscetíveis e posteriormente cruzamentos entre acessos resistentes versus suscetíveis e resistentes versus resistentes foram realizados visando obter maiores informações sobre a genética dessa resistência. 


\subsection{Material e Métodos}

\subsubsection{Triagem da coleção de Capsicum chinense.}

A reação ao oídio de um total de vinte acessos de Capsicum chinense da coleção da ESALQ/USP foram triadas para identificar fontes de resistência. As respectivas origens de cada germoplasma constam nas Tabelas 7 e 8 .

\subsubsection{Produção de mudas, condução, inoculação e avaliação.}

Os experimentos foram conduzidos em casa de vegetação junto ao Departamento de Produção Vegetal da Escola Superior de Agricultura "Luiz de Queiroz”, no município de Piracicaba, SP, que está a uma latitude de $22^{\circ} 42^{\prime} 30^{\prime}$ ' sul, longitude $47^{\circ} 38^{\prime} 00^{\prime}$ " oeste e uma altitude de 546 m (Kuabara, 1984). Segundo a classificação de Köppen, o clima da região é Cwa: subtropical úmido, com três meses mais secos (jun./jul./ago.), chuvas de verão e seca de inverno, temperatura do mês mais quente maior que $22^{\circ} \mathrm{C}$ e média de $21,4^{\circ} \mathrm{C}$.

A semeadura dos acessos foi feita no mês de setembro de 2000 em bandejas de poliestireno expandido de 128 células. Quando as mudas apresentavam de 3 a 5 pares de folhas verdadeiras, foi realizado o transplante para vasos plástico de oito litros contendo três partes de areia lavada, duas de vermiculita e uma de condicionador de solo.

O sistema de irrigação adotado foi o de gotejamento, regulado eletronicamente por um temporizador. A adubação foi feita utilizando-se Kristalon ${ }^{\circledR}$ 13-40-13, $1 \mathrm{~g} / 1$ na fase de muda e após o transplante Kristalon ${ }^{\circledR}$ 12-12-36 mais micronutrientes, nitrato de cálcio $(300 \mathrm{~g} / 2501), \mathrm{Ca} / \mathrm{B}(70 \mathrm{ml} / 2501)$ e sulfato de magnésio $(400 \mathrm{~g} / 2501)$ fornecidos via fertirrigação, monitorados por um condutivímetro.

O tutoramento das plantas foi feito através de espaldeira dupla onde as duas linhas de plantas foram tutoradas por fios de arame. No controle preventivo de pragas e doenças foi utilizado Confidor ${ }^{\circledR}$ (Imidacloprid), Vertimec $\AA$ (Abamectina) e Aplaud $®$ (Buprofezin) nas dosagens recomendadas. Visando não interferir a reação natural de cada acesso nenhum fungicida foi aplicado. 
Para estabelecer e promover a epidemia de oídio no processo de triagem dos acessos de $C$. chinense, utilizou-se uma relação de uma planta altamente suscetível de pimentão híbrido (C. annuum) previamente infectada, servindo como linha espalhadora da doença, para cada 15 acessos a serem triados.

As avaliações semanais das reações foram feitas com o surgimento dos sintomas, iniciando-se na fase de frutificação, totalizando seis avaliações. Foi utilizada uma escala de notas de 1 a 5, de acordo com a severidade da doença, proposta por Ullasa et al. (1981) (Tabela 1). Com o objetivo de treinar a reconhecer e efetuar o critério visual, folhas com diferentes níveis de sintomas foram coletadas e passadas por um medidor de área foliar (Leaf Área Meter, modelo LI-3000 da Licor) obtendo-se a área foliar total e lesionada. Com base nesta medida estimou-se a severidade da doença. Usando estes modelos referenciais, foi possível padronizar a avaliação. Para monitorar a expressão da doença foram usadas testemunhas referenciais com reações conhecidas baseadas tanto por produtores quanto pela literatura (Tabela 2).

Tabela 1. Escala de notas para avaliação da reação de Capsicum a Leveillula taurica

\begin{tabular}{ccc}
\hline Notas & Sintomas & Reação \\
\hline 1 & Resistente, sem sintomas & $\mathrm{R}$ \\
2 & Moderadamente resistente, com 10\% da área foliar afetada & $\mathrm{MR}$ \\
3 & Moderadamente suscetível, com 11-20\% da área foliar afetada & $\mathrm{MS}$ \\
4 & Suscetível, com 21-50\% da área foliar afetada & $\mathrm{S}$ \\
5 & Altamente suscetível, com 51\% ou mais da área foliar afetada & $\mathrm{AS}$ \\
\hline
\end{tabular}

Tabela 2. Testemunhas referenciais de resistência e suscetibilidade com relação à reação a Leveillula taurica

\begin{tabular}{clcc}
\hline Hospedeiros referenciais & Espécie & Procedência & Reação \\
\hline HV12 & C. annuum & SVS, Paulínia & $\mathrm{R}$ \\
PI 152225 & C. chinense & USDA-USA & $\mathrm{R}$ \\
Margarita & C. annuum & Syngenta & $\mathrm{S}$ \\
Magali R & C. annuum & Sakata & $\mathrm{S}$ \\
\hline
\end{tabular}




\subsubsection{Análise estatística.}

O delineamento experimental foi em blocos casualizados com quatro plantas por vaso, totalizando 80 plantas.

Os dados obtidos foram submetidos à análise estatística pelo método GLIM, realizado com auxílio do Professor José Eduardo Corrente, Departamento de Ciências Exatas, ESALQ/USP. Na análise levaram em conta todos os dados das seis avaliações. O programa GLIM utiliza-se de um modelo logístico acumulado, onde se supõe que a distribuição original dos dados é Poisson. Deste modo, com as estimativas dos pontos de corte da análise original, pôde-se caracterizar a reação dos acessos resistentes através das estimativas dos efeitos dos parâmetros (acessos) ajustados e dos respectivos desviospadrão.

Visando-se comparar os resultados obtidos na primeira análise foi aplicado Teste de Tukey a $5 \%$ de probabilidade aos dados coletados. A análise de variância consta no anexo A.

\subsubsection{Herança da reação}

\subsubsection{Estimação de parâmetros genéticos.}

Após a etapa de triagem, dois acessos identificados como moderadamente suscetíveis e dois resistentes foram usados como progenitores obtendo-se de três cruzamentos (Tabela 3). O processo de hibridação foi feito através da emasculação de botões florais eliminando-se as anteras, seguida de polinização usando flores recém abertas (Nuez et al., 1996). Cada cruzamento foi devidamente identificado através de etiquetas amarradas ao pedicelo da flor e os frutos resultantes da autofecundação foram eliminados.

Tabela 3. Relação dos híbridos de pimenta

\begin{tabular}{cc}
\hline Híbridos & Reações \\
\hline Pimenta Doce IH-1761 x Pimenta Cheiro 1 & Moderadamente suscetível x resistente \\
Pimenta Índio x PI 152225 & Moderadamente suscetível x resistente \\
Pimenta Doce IH-1761 x PI 152225 & Moderadamente suscetível x resistente \\
\hline
\end{tabular}




\subsubsection{Produção de mudas, condução, inoculação e avaliação dos híbridos $\left(F_{1}\right)$ e progenitores.}

A semeadura das gerações $F_{1}$, progenitores e testemunhas foi feita em bandejas de poliestireno expandido de 128 células, preenchidas com substrato para hortaliças (Gioplant ${ }^{\circledR}$ ). O transplante para vasos plásticos de oito litros contendo mistura de solo, vermiculita e condicionador de solo (3:1:1) foi realizado no mês de outubro de 2001. As plantas foram dispostas em fileiras duplas espaçadas de 1,0 m entre elas.

Os tratos culturais foram os tradicionais do cultivo em estufa, já descritos no item 5.2.1.1. O delineamento experimental foi inteiramente casualizado com três plantas por vaso (parcela), três repetições e nove tratamentos, sendo três híbridos, quatro progenitores e duas testemunhas suscetíveis, totalizando 81 plantas.

A técnica de inoculação e estabelecimento da epidemia de oídio foi feita através plantas de pimentão com alta incidência e esporulação, que funcionaram como linhas espalhadoras da doença. As avaliações das reações dos acessos de C. chinense foram feitas por meio de escala de notas de acordo com a severidade da doença como descrito por proposta por Ullasa et al. (1981) (idem item 5.2.1.1). Adotou-se o critério de encerrar as avaliações quando as testemunhas referenciais de suscetibilidade, Magali R e Margarita, obtiveram nota máxima 5, considerando assim a reação de cada acesso referente a nota dada nessa avaliação.

A geração $F_{1}$ foi avaliada em duas etapas, na ocasião de sua obtenção e junto a geração $\mathrm{F}_{2}$ onde esta foi plantada novamente, visando-se ter as mesmas condições ambientais de avaliação da geração $\mathrm{F}_{2}$.

\subsection{Retrocruzamento}

O híbrido Pimenta Índio x PI 152225 foi retrocruzado para seu progenitor resistente, PI 152225, com o objetivo de aumentar a freqüência gênica da resistência para fins de melhoramento e auxiliar na elucidação da herança da resistência. 


\subsection{Produção de mudas, condução, inoculação e avaliação $\operatorname{dos} F_{2}, F_{1}$, retrocruzamentos e progenitores.}

A semeadura das gerações $F_{2}, F_{1}$, retrocruzamento e progenitores, foi realizada no mês de abril de 2003 e o transplante no mês de junho de 2003 para vasos plásticos de

oito litros, contendo substrato formulado pela Multiplanta Substrato Agrícola com a seguinte composição: casca de Pinus composta, granulação $10 \mathrm{~mm}$, vermiculita expandida, turfa processada, macro e micro nutrientes (fosfato super simples e Humix), areia $(5 \%)$ e elemento dispersante de umidade.

Os tratos culturais realizados foram os usualmente utilizados para a cultura: irrigação, tutoramento e tratos fitossanitários prevenindo pragas e doenças, já detalhados nas etapas anteriores. (item 5.2.1.1).

O delineamento experimental foi inteiramente casualizado com cinco plantas por vaso, totalizando 2.203 plantas (Tabela 4).

A inoculação e disseminação foram feitas através de plantas de pimentão com alta intensidade de esporulação, servindo como linhas espalhadoras da doença, na proporção de 1:20 como já descrito no item 5.2.2.1.1. Quando as plantas testemunhas, Magali R e Margarita, atingiram nota máxima 5 foi realizada a avaliação das gerações a serem testadas, fazendo a leitura da reação da planta ao patógeno. A avaliação foi feita através da escala de notas de acordo com a severidade da doença como descrito nas etapas anteriores. 
Tabela 4. Número de plantas avaliadas por geração

\begin{tabular}{lc}
\hline \multicolumn{1}{c}{ Gerações } & $\mathbf{N}^{\mathbf{0}}$ de Plantas \\
\hline (Pimenta Doce IH-1761 x Pimenta Cheiro 1) $\mathrm{P}_{1}$ & 55 \\
$\mathrm{P}_{2}$ & 55 \\
$\mathrm{~F}_{1}$ & 50 \\
$\mathrm{~F}_{2}$ & 522 \\
$\left(\right.$ Pimenta Índio X PI 152225) $\mathrm{P}_{1}$ & 60 \\
$\mathrm{P}_{2}$ & 50 \\
$\mathrm{~F}_{1}$ & 55 \\
$\mathrm{~F}_{2}$ & 540 \\
Retro P & 106 \\
$\left(\right.$ Pimenta Doce IH-1761 x PI 152225) $\mathrm{P}_{1}$ & 55 \\
$\mathrm{P}_{2}$ & 50 \\
$\mathrm{~F}_{1}$ & 55 \\
$\mathrm{~F}_{2}$ & 470 \\
Testemunha Magali R & 40 \\
Testemunha Margarita & 40 \\
\hline
\end{tabular}

\subsection{Análise biométrica dos dados.}

Para a realização das análises biométricas foram utilizados os dados das gerações, $\mathrm{P}_{1}, \mathrm{P}_{2}, \mathrm{~F}_{1}$ e $\mathrm{F}_{2}$ e retrocruzamento. Como havia sido comentado anteriormente, os progenitores e as gerações $F_{1}$ foram avaliadas em duas etapas, na ocasião de sua obtenção e novamente junto a avaliação da geração $F_{2}$. Para que todas as gerações tivessem influência das mesmas condições ambientais utilizaram-se para o cálculo das análises os dados referentes a segunda avaliação.

O número de plantas dentro de cada classe de notas foi totalizado e a partir disso, estimadas as médias ponderadas [m], o somatório dos efeitos de aditividade [a] e dominância [d], usando o método de escala conjunta proposto por Cavali e descrito por Mather e Jinks (1984), baseado nas médias esperadas do caráter para as gerações, desconsiderando os efeitos epistáticos. Visando determinar os tipos de ação gênica 
envolvidas no modelo genético aditivo-dominante, tem-se os seguintes valores esperados:

$$
\begin{gathered}
\mathrm{E}\left[\overline{\mathrm{Y}}_{(\mathrm{PR})}\right]=\mathrm{m}-[\mathrm{a}] \\
\mathrm{E}\left[\overline{\mathrm{Y}}_{(\mathrm{PS})}\right]=\mathrm{m}+[\mathrm{a}] \\
\mathrm{E}\left[\overline{\mathrm{Y}}_{(\mathrm{F} 1)}\right]=\mathrm{m}+[\mathrm{d}] \\
\mathrm{E}\left[\overline{\mathrm{Y}}_{(\mathrm{F} 2)}\right]=\mathrm{m}+(1 / 2)[\mathrm{d}] \\
\mathrm{E}\left[\overline{\mathrm{Y}}_{(\mathrm{RCPR})}\right]=\mathrm{m}-(1 / 2)[\mathrm{a}]+(1 / 2)[\mathrm{d}]
\end{gathered}
$$

Sendo: $\mathrm{m}=$ média geral do caráter;

[a] = somatório dos efeitos aditivos;

[d] = somatório dos efeitos de dominância;

$\mathrm{E}[\overline{\mathrm{Y}}]=$ esperança matemática da média das gerações $\mathrm{P}_{\mathrm{R}}, \mathrm{P}_{\mathrm{S}}, \mathrm{F}_{1}, \mathrm{~F}_{2}$ e $\mathrm{RC}_{\mathrm{PR}}$

Admitindo que a maioria dos genes favoráveis para as características estudadas estão acumuladas em uma das linhagens genitoras e os desfavoráveis na outra e que as médias esperadas são expressáveis conforme acima, foi possível estimar os efeitos de m, [a] e [d] considerando as médias das diversas gerações.

Após o cálculo das variâncias foi feito um ajuste do número de graus de liberdade conjunto, para citações de heterogeneidade nas variâncias das gerações conforme Gomes (1990).

A adequação do modelo genético aditivo-dominante, adotado com base nos três parâmetros, m, [a] e [d] foi verificada pelo teste t por meio de contrastes entre médias segundo Gomes (1990). Nesses testes comparou-se a média observada da geração $F_{2}$ com seu valor esperado, conforme o modelo. Em caso de significância do teste t, adotouse modelo com efeitos epistáticos, componentes das médias das gerações $(\mathrm{PR}=\mathrm{m}-[\mathrm{a}]+$ $[\mathrm{i}] ; \mathrm{PS}=\mathrm{m}+[\mathrm{a}]+[\mathrm{i}] ; \mathrm{F}_{1}=\mathrm{m}+[\mathrm{d}]+[1], \mathrm{F}_{2}=\mathrm{m}+(1 / 2)[\mathrm{d}]+(1 / 4)[1]$ e $\mathrm{RC}_{\mathrm{PR}}=\mathrm{m}-(1 / 2)[\mathrm{a}]+$ $(1 / 2)[\mathrm{d}]+(1 / 4)[1])$, além dos efeitos aditivo e dominante. Para mensurar esses efeitos, considerou-se o conteúdo genético do contraste:

$$
\mathrm{C}=\overline{\mathrm{Y}}_{\mathrm{F} 2}-(1 / 4)\left(\overline{\mathrm{Y}}_{\mathrm{PR}}+\overline{\mathrm{Y}}_{\mathrm{PS}}+2 \overline{\mathrm{Y}}_{\mathrm{F} 1}\right)
$$


Cuja esperança matemática é

$$
\mathrm{E}(\mathrm{C})=(1 / 2)[\mathrm{i}]+(1 / 4)[1]
$$

Nesta esperança de C, o parâmetro [i] é a soma dos efeitos epistáticos do tipo aditivo x aditivo e o parâmetro [1] a soma dos efeitos epistáticos do tipo dominante $\mathrm{x}$ dominante (Mather e Jinks, 1984). Evidentemente E(C) será nula no caso de ausência de efeitos epistáticos.

Foram construídos histogramas de distribuição de freqüência de plantas para a realização de uma análise exploratória dos dados, com o intuito de visualizar melhor o comportamento das médias dentro de cada classe de notas nas diferentes gerações.

Como na coleção de $C$. chinense da ESALQ/USP não foram identificados acessos que pudessem ser considerados suscetíveis, sendo, portanto a reação dos progenitores usados nos cruzamentos não contratantes, o número de locos segregantes não pode ser calculado.

Os coeficientes de herdabilidade também foram calculados para cada cruzamento conforme segue:

$$
\mathrm{h}^{2}=\sigma_{\mathrm{g}}^{2} / \sigma_{\mathrm{f}}^{2}
$$

onde, $\mathrm{h}^{2}=$ coeficiente de herdabilidade

$\sigma_{\mathrm{g}}^{2}=$ variância genética

$\sigma_{\mathrm{f}}^{2}=$ variância fenotípica

A variância genética e a variância fenotípica foram estimadas por:

$$
\begin{gathered}
\sigma_{g}^{2}=\sigma_{F 2}^{2}-\left[\left(\sigma_{P 1}^{2}+\sigma_{P 2}^{2}+2 \sigma_{F 1}^{2}\right) / 4\right] \\
\sigma_{f}^{2}=\sigma_{F 2}^{2}
\end{gathered}
$$

A partir dos coeficientes de herdabilidade foram calculados os ganhos de seleção esperados para a geração $F_{3}$. Simulou-se seleção das plantas com notas 1 e 2 .

$$
\mathrm{Gs} \leq \mathrm{ds} \cdot \mathrm{h}^{2}
$$

Onde, Gs = ganho de seleção

ds = diferencial de seleção

$\mathrm{h}^{2}=$ coeficiente de herdabilidade 
Sendo o diferencial de seleção calculado por:

$$
\mathrm{ds}=\overline{\mathrm{Y}}_{\mathrm{s}}-\overline{\mathrm{Y}}_{\mathrm{F} 2}
$$

Onde, $\overline{\mathrm{y}}_{\mathrm{s}}=$ média geral das progênies selecionadas.

$\overline{\mathrm{Y}}_{\mathrm{F} 2}=$ média da geração $\mathrm{F}_{2}$.

Os coeficientes de herdabilidade e os ganhos de seleção foram calculados com base na herdabilidade no sentido amplo. Essa estimativa do progresso (Gs) é adequada em casos de ausência de dominância. Havendo evidência de dominância o valor de Gs estará super estimado, servindo apenas como referencial.

As análises biométricas foram feitas com auxílio do Prof. Dr. Roland Vencovsky do Departamento de Genética da ESALQ/USP.

\subsubsection{Reação de híbridos de pimenta resistentes ao oídio em $C$. chinense}

Nesta etapa, visando-se verificar se os genes que controlam a resistência ao oídio, nos diferentes progenitores resistentes teriam os mesmos mecanismos, quatro progenitores identificados como resistentes na etapa de triagem foram cruzados entre si dando origem a três gerações $F_{1}$ e $F_{2}$ e suas reações avaliadas (Tabela 5).

Tabela 5. Relação dos híbridos

\begin{tabular}{cc}
\hline Híbridos & Reações \\
\hline Habanera x Pimenta Cheiro Laranja & Resistente x resistente \\
Habanera x PI 152225 & Resistente x resistente \\
Santarém \#50 x PI 152225 & Resistente x resistente \\
\hline
\end{tabular}

\subsection{Produção de mudas, condução, inoculação e avaliação dos híbridos $\left(F_{1}\right)$ e progenitores.}

A produção das mudas, tratos culturais, inoculação e as avaliações foram realizadas da mesma maneira já descrita no item 5.2.1.1. O delineamento experimental foi inteiramente casualizado com três plantas por parcela, três repetições e 9 tratamentos (três híbridos, quatro progenitores e duas testemunhas suscetíveis), totalizando 81 plantas. 
5.2.2.2.2 Produção de mudas, condução, inoculação e avaliação $\operatorname{dos} F_{2}, F_{1}$, e progenitores.

As metodologias para a realização das etapas, desde a produção de mudas até as avaliações, foram realizadas da mesma forma já relatada no item 5.2.2.1.3. O delineamento experimental foi inteiramente casualizado com cinco plantas por vaso, compondo um total de 1903 plantas: (Tabela 6).

Tabela 6. Número de plantas por geração de C. chinense avaliadas segundo escala de notas

\begin{tabular}{lc}
\hline \multicolumn{1}{c}{ Gerações } & $\mathbf{N}^{\mathbf{0}}$ de Plantas \\
\hline (Habanera x Pimenta Cheiro Laranja) $\mathrm{P}_{1}$ & 45 \\
$\mathrm{P}_{2}$ & 50 \\
$\mathrm{~F}_{1}$ & 20 \\
$\mathrm{~F}_{2}$ & 527 \\
$\left(\right.$ Habanera X PI 152225) $\mathrm{P}_{1}$ & 45 \\
$\mathrm{P}_{2}$ & 50 \\
$\mathrm{~F}_{1}$ & 50 \\
$\mathrm{~F}_{2}$ & 527 \\
(Santarem \#50 X PI 152225) $\mathrm{P}_{1}$ & 45 \\
$\mathrm{P}_{2}$ & 50 \\
$\mathrm{~F}_{1}$ & 30 \\
$\mathrm{~F}_{2}$ & 384 \\
Testemunhas & \\
Magali R & 40 \\
Margarita & 40 \\
\hline
\end{tabular}

\subsection{Análise biométrica dos dados.}

Para a realização das análises biométricas foram utilizados os dados das gerações, $\mathrm{P}_{1}, \mathrm{P}_{2} \mathrm{~F}_{1}$ e $\mathrm{F}_{2}$. Como havia sido comentado anteriormente, os progenitores e as gerações 
$\mathrm{F}_{1}$ foram avaliadas em duas etapas, ou seja, em dois ensaios, na ocasião de sua obtenção e novamente quando a geração $F_{2}$ foi avaliada. Para que todas as gerações tivessem influência das mesmas condições ambientais utilizaram-se para o cálculo das análises os dados referentes a segunda avaliação.

Feita as avaliações, o número de plantas dentro de cada classe de notas foi totalizado e estimadas as médias ponderadas [m], o somatório dos efeitos de aditividade [a] e dominância [d] visando verificar se havia ou não diferenças entre os mecanismos genéticos dos progenitores. A adequação do modelo foi verificada pelo teste t por meio de contrastes entre médias segundo Gomes (1990). Em caso de significância do teste t, adotou-se modelo com efeitos epistáticos. Após o cálculo das variâncias foi feito um ajuste do número de graus de liberdade conjunto, para citações de heterogeneidade nas variâncias das gerações conforme Gomes (1990). Um melhor detalhamento dessa análise foi descrito no item 5.2.2.1.4.

Histogramas de distribuição das gerações foram feitos para visualizar melhor o comportamento das médias dentro de cada classe de notas nas diferentes gerações.

\subsection{Resultados e Discussão}

\subsubsection{Triagem da coleção de Capsicum chinense.}

Assim como em C. baccatum, e mais uma vez confirmando os resultados obtidos por Shifriss et al. (1992), Daubeze et al. (1995), Souza \& Café Filho (2000) e Lima (2002), a espécie C. chinense foi altamente resistente, representando $85 \%$ dos acessos testados (Tabela 7). Pela análise GLIM apenas os acessos Pimenta Índio, Pimenta Doce IH-1761 e Pimenta Doce IH-1763, cujas médias foram 2,50, 2,25 e 2,75, apresentaram reações diferenciadas da resistência dos demais acessos, sendo consideradas moderadamente suscetíveis.

Como já havia sido comentado nos capítulos anteriores, as reações dos acessos nas espécies $C$. baccatum e também em C. chinense foram diferentes das observadas em $C$. annuum. Nessas espécies a esporulação foi mínima e o sintoma de "fleck" típico de reação de hipersensibilidade ao fungo foi freqüente, como exemplo no acesso Pimenta Índio (foto anexo E). A espécie C. chinense se comparada a C. baccatum apresenta uma 
proporção ainda maior de acessos resistentes. Mesmo os três acessos diferenciados, considerados moderadamente suscetíveis apresentaram menor intensidade de esporulação quando comparada aos acessos com notas similares de C. annuum. Segundo Reifschneider et al. (1998), nas espécies C. baccatum, C. chinense e C. frutescens os genes de resistência a pragas e doenças foram altamente preservados em sua domesticação. Nessas espécies é bastante comum a resistência ao crescimento do patógeno, descrita por Russel (1976), no qual o desenvolvimento do fungo é inibido afetando a patogênese, aumentando o período de latência (Figura 1).

Os acessos da espécie $C$. chinense, mostraram-se com altos níveis de resistência e, portanto excelentes fontes de resistência a ser explorada.

Tabela 7. Listagem dos acessos resistentes e médias de suas reações, por avaliação. $C$. chinense. 2001

\begin{tabular}{lcc}
\hline \multicolumn{1}{c}{ Acessos } & Origem & Médias \\
\hline PI 152225 & USDA - USA & $1,00 \mathrm{~B}$ \\
Pimenta Cheiro Laranja & Belém - PA & $1,00 \mathrm{~B}$ \\
Pimenta Cheiro 2 & Belém - PA & $1,00 \mathrm{~B}$ \\
Pimenta Doce IH-1749 & Benjamin Constant - AM & $1,00 \mathrm{~B}$ \\
Pimenta Doce & Belém - PA & $1,00 \mathrm{~B}$ \\
Muripi IH-1477 & Manaus - AM & $1,00 \mathrm{~B}$ \\
Pimenta n 2 & Manaus - AM & $1,25 \mathrm{~B}$ \\
Bode & Recife - PE & $1,25 \mathrm{~B}$ \\
Rabo de Macaco & Piauí - PI & $1,50 \mathrm{AB}$ \\
Pimenta n 5 & Manaus - AM & $1,50 \mathrm{AB}$ \\
Muripi IH-1490 & Manaus - AM & $1,50 \mathrm{AB}$ \\
Pimenta Cheiro 1 & Belém - PA & $1,75 \mathrm{AB}$ \\
Pimenta Doce IH-1750 & Benjamin Constant - AM & $1,75 \mathrm{AB}$ \\
Pimenta Doce IH-1766 & Benjamin Constant - AM & $1,75 \mathrm{AB}$ \\
Santarem \#50 & Santarém - PA & $2,00 \mathrm{AB}$ \\
ICA \#39 & Colômbia & $2,00 \mathrm{AB}$ \\
Habanera & México & $2,00 \mathrm{AB}$ \\
\hline 1. Médias seguidas pela mesma letra na coluna, não diferem entre si, ao nível de 5\% de probabilidade pelo \\
teste de Tukey.
\end{tabular}


Tabela 8. Listagem dos acessos moderadamente suscetíveis e médias de suas reações. $C$. chinense. 2001

\begin{tabular}{lccccccc}
\hline & & \multicolumn{5}{c}{ Média de notas por avaliação (dias) $^{\mathbf{1}}$} \\
\multicolumn{1}{c}{ Acessos } & Origem & $\mathbf{7}$ & $\mathbf{1 4}$ & $\mathbf{2 1}$ & $\mathbf{2 8}$ & $\mathbf{3 5}$ & $\mathbf{4 2}$ \\
\hline Pimenta Índio & Belém - PA & 1,00 & 1,00 & 1,50 & 2,00 & 2,50 & $2,50 \mathrm{AB}$ \\
Pimenta Doce IH-1761 & Benj. Constant - AM & 1,00 & 1,50 & 2,00 & 2,25 & 2,25 & $2,25 \mathrm{AB}$ \\
Pimenta Doce IH-1763 & Benj. Constant - AM & 1,50 & 2,00 & 2,25 & 2,25 & 2,75 & $2,75 \mathrm{~A}$ \\
\hline
\end{tabular}

1. Médias seguidas pela mesma letra na coluna, não diferem entre si, ao nível de $5 \%$ de probabilidade, pelo teste de Tukey.

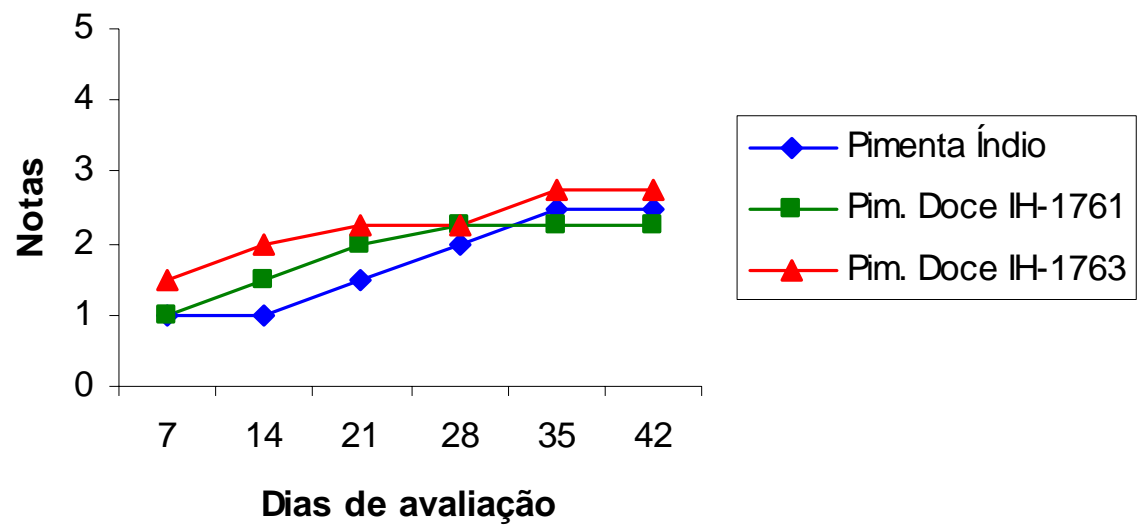

Figura 1 - Progresso da doença dos acessos moderadamente suscetíveis de C.chinense

\subsubsection{Herança da reação}

\subsubsection{Estimação de parâmetros genéticos.}

Os progenitores resistentes e moderadamente suscetíveis mantiveram suas reações apenas com pequenas variações nos valores se comparados aos mesmos na etapa de triagem. Os progenitores resistentes Pimenta cheiro 1 e PI 152225 que apresentaram na etapa de triagem realizada no ano de 2001, médias de 1,75 e 1,00, na última avaliação (junto as gerações $F_{2}$ ) em 2003, apresentaram médias de 1,45 e 1,24 respectivamente. Do mesmo modo ocorreu com os progenitores moderadamente suscetíveis Pimenta Doce IH-1761 e Pimenta Índio, que na primeira etapa de triagem apresentaram médias de 2,25 e 2,50 e na última avaliação médias de 2,56 e 2,63 respectivamente (Tabela 10). Essas variações são normais e de influência ambiental (Lima, 2002, Reuveni 1974). 
Um fato interessante observado nos acessos e gerações posteriores nesta espécie foi a constante defoliação como reação ao oídio mesmo nos acessos resistentes (Foto anexo F). Segundo Lima (2002) esse fenômeno ocorre também nas espécies $C$. baccatum e $C$. frutescens e está atribuindo à característica fenológica da planta e a variações de umidade e temperatura. Sugere-se uma outra explicação relacionada ao tipo de mecanismo de resistência da planta, sendo uma reação de hipersensibilidade tanto ao patógeno em si, como a intensidade ou pressão de inóculo presente durante o experimento (Russel, 1976; Carver et al., 1995 e Zeyen et al., 1995). Acredita-se que em situação de cultivo em larga escala, sem adjacência de fonte de inóculo do patógeno, haja maior retenção foliar.

Os resultados observados na segunda avaliação da geração $F_{1}$ mostram que para todos os cruzamentos o número de plantas se encaixam nas classes 1 e 2 , indicando alta resistência com médias de 1,74 para o cruzamento Pim. Doce IH-1761 x Pim. Cheiro 1, 1,73 para Pimenta Índio x PI 152225 e 1,18 para Pimenta Doce IH-1761 x PI 152225. O mesmo ocorreu para as respectivas gerações $\mathrm{F}_{2}$, onde a proporção de plantas com notas 3 e 4 foi de apenas $4,0 \%, 6,6 \%$ e $4,8 \%$ respectivamente e plantas com nota 5 foram inexistentes (Tabela 9, Figuras de 2 a 4).

Os resultados dos parâmetros heterose e epistasia mostraram que a herança da resistência em $C$. chinense é dominante quanto a reação de resistência, concordando com C. baccatum. Os resultados da análise genética indicaram que houve manifestação de dominância e de epistasia em todos os cruzamentos realizados, sendo essas negativamente significativas. $O$ fato de esses parâmetros terem se apresentado significativos é extremamente valioso para o melhoramento em questão, pois mostra, no caso dos valores de heterose, que as gerações $F_{1}$ apresentaram menor severidade da doença do que a média da severidade dos progenitores. No caso dos valores de epistasia em $F_{2}$, mostraram que a freqüência de plantas $F_{2}$ suscetíveis observada foi menor que a esperada. Quando se pretende explorar o vigor híbrido esse fator é muito útil e vantajoso para o melhorista (Tabela 11).

A epistasia apresentada no retrocruzamento (Pimenta Índio x PI 152225) x PI 152225 confirmou os resultados obtidos na geração $F_{2}$ tendo também sido significativa. 
O número de plantas com notas 1 e 2 aumentou em 2,9\% no retrocruzamento e a média ponderada passou de 1,56 para 1,32 .

A análise genética realizada para o germoplasma utilizado neste trabalho em questão, mostrou que os componentes que envolvem a variância genética nos cruzamentos foram aditivos, dominantes e epistáticos $\left(\sigma^{2} g=\sigma^{2 a}+\sigma^{2} d+\sigma^{2} i\right)$.

Apesar dos materiais utilizados neste germoplasma não permitirem a identificação do número de locos segregantes, devido à proximidade nas reações entre os progenitores resistentes e suscetíveis, não sendo contrastantes. Poderíamos afirmar que essa herança, assim como em C. annuum e C. baccatum, é de natureza poligênica sendo governada por mais de dois genes. Tal afirmação pode ser feita em função da ocorrência de tipos transgressivos apresentados na geração $F_{2}$. Para todos os cruzamentos avaliados, enquanto os progenitores resistentes apresentam reações dentro das notas 1 e 2 e suscetíveis entre as notas 2 e 3, os indivíduos da geração $F_{2}$ apresentam variações de até nota 4 , ou seja, além das médias de seus progenitores, caracterizando uma herança poligênica (Tabela 9).

Os valores de herdabilidades e ganhos de seleção foram moderados, sendo de $35,5 \%$ e 1,7\% para o cruzamento Pimenta Doce IH-1761 x Pimenta Cheiro 1, de 50,4\% e 3,5\% para Pimenta Índio x PI 152225 e de 49,0\% e 2,7\% para Pimenta Doce IH-1761 x PI 152225 (Tabela 10). Como não se realizou retrocruzamentos para ambos os progenitores, resistentes e suscetíveis, calculando-se a herdabilidade apenas no sentido amplo, pode-se inferir que estes valores estão superestimados. Os valores de herdabilidade fornecem importantes informações sobre a genética da resistência. Quanto maior for o valor de herdabilidade, menor será a possibilidade de interferências ambientais, facilitando o progresso seletivo para a resistência.

Os resultados observados em $C$. chinense são similares aos apresentados em $C$. baccatum. Poderia-se postular que a herança da resistência nessas espécies são semelhantes. Esse fato já era imaginado já que elas parecem ter mecanismos de resistência parecidos. Convém ressaltar que o número de acesos resistentes (notas 1 e 2) em C. chinense e C. baccatum é notadamente maior que em C. annuum. Infelizmente essas espécies têm limitações no uso de híbridos interespecíficos. Só existe a 
possibilidade de usar $C$. chinense em cruzamentos interespecíficos com C. annuum desde que sejam identificadas combinações varietais compatíveis em ambas as espécies.

Tabela 9. Número de plantas em cada classe, de acordo com a escala de notas para resistência a Leveillula taurica em condições de casa de vegetação. C. chinense. 2003

\begin{tabular}{|c|c|c|c|c|c|c|}
\hline Gerações $^{1}$ & & $\begin{array}{c}\mathrm{R} \\
\text { Nota } 1 \\
\end{array}$ & $\begin{array}{c}\text { MR } \\
\text { Nota } 2 \\
\end{array}$ & $\begin{array}{c}\text { MS } \\
\text { Nota } 3 \\
\end{array}$ & $\begin{array}{c}\text { S } \\
\text { Nota } 4 \\
\end{array}$ & $\begin{array}{c}\text { AS } \\
\text { Nota } 5 \\
\end{array}$ \\
\hline & $\mathrm{PR}^{\bullet}$ & 0 & 6 & 3 & 0 & 0 \\
\hline \multirow[t]{2}{*}{ Pimenta Cheiro 1} & $\mathrm{PR}^{\bullet \bullet}$ & 30 & 25 & 0 & 0 & 0 \\
\hline & $\mathrm{PR}^{\bullet}$ & 9 & 0 & 0 & 0 & 0 \\
\hline \multirow[t]{2}{*}{ PI 152225} & $\mathrm{PR}^{\bullet \bullet}$ & 38 & 12 & 0 & 0 & 0 \\
\hline & $\mathrm{PMS}^{\bullet}$ & 0 & 2 & 7 & 0 & 0 \\
\hline \multirow[t]{2}{*}{ Pimenta Doce IH-1761 } & $\mathrm{PMS}^{\bullet \bullet}$ & 0 & 24 & 31 & 0 & 0 \\
\hline & $\mathrm{PMS}^{\bullet}$ & 0 & 3 & 6 & 0 & 0 \\
\hline \multirow[t]{2}{*}{ Pimenta Índio } & $\mathrm{PMS}^{\bullet \bullet}$ & 0 & 22 & 38 & 0 & 0 \\
\hline & $\mathrm{TS}^{\bullet}$ & 0 & 0 & 0 & 0 & 9 \\
\hline \multirow[t]{2}{*}{ Magali R } & $\mathrm{TS}^{\bullet \bullet}$ & 0 & 0 & 0 & 0 & 40 \\
\hline & $\mathrm{TS}^{\bullet}$ & 0 & 0 & 0 & 0 & 9 \\
\hline \multirow[t]{2}{*}{ Margarita } & $\mathrm{TS}^{\bullet \bullet}$ & 0 & 0 & 0 & 0 & 40 \\
\hline & $\mathrm{F}_{1}^{\bullet}$ & 0 & 5 & 4 & 0 & 0 \\
\hline Pim. Doce IH-1761 x Pimenta Cheiro & $\mathrm{F}_{1} \bullet$ & 13 & 37 & 0 & 0 & 0 \\
\hline \multirow[t]{2}{*}{1} & $\mathrm{~F}_{2} \bullet \bullet$ & 298 & 203 & 19 & 2 & 0 \\
\hline & $\mathrm{F}_{1}^{\bullet}$ & 0 & 9 & 0 & 0 & 0 \\
\hline \multirow[t]{4}{*}{ Pimenta Índio x PI 152225} & $\mathrm{~F}_{1} \bullet \bullet$ & 15 & 40 & 0 & 0 & 0 \\
\hline & $\mathrm{F}_{2} \bullet \bullet$ & 277 & 227 & 31 & 5 & 0 \\
\hline & $\mathrm{RC} \mathrm{PR}^{\bullet \bullet}$ & 76 & 26 & 4 & 0 & 0 \\
\hline & $\mathrm{F}_{1}{ }^{\bullet}$ & 9 & 0 & 0 & 0 & 0 \\
\hline \multirow[t]{2}{*}{ Pimenta Doce IH-1761 x PI 152225} & $\mathrm{~F}_{1} \bullet \bullet$ & 45 & 10 & 0 & 0 & 0 \\
\hline & $\mathrm{F}_{2} \bullet \bullet$ & 291 & 156 & 21 & 2 & 0 \\
\hline
\end{tabular}

- Resultados obtidos em fevereiro de 2002 (primeira avaliação) - na obtenção da geração $\mathrm{F}_{1}$.

• Resultados obtidos em setembro de 2002 (segunda avaliação) - na obtenção da geração $F_{2}$.

1. PR - Progenitor resistente, PMS - progenitor moderadamente suscetível, RC PR retrocruzamento, TS - Testemunha suscetível 
Tabela 10. Estimativas de médias, variâncias e da herdabilidade $\left(\mathrm{h}^{2}\right)$ nas diferentes gerações de cinco cruzamentos e ganho de seleção esperado em $\mathrm{F}_{3}(\mathrm{Gs})$. C. chinense. 2003

\begin{tabular}{|c|c|c|c|c|c|c|}
\hline Gerações $^{1}$ & & $\eta$ & Médias & Variâncias & $h^{2}(\%)$ & Gs (\%) \\
\hline \multirow{3}{*}{ Pimenta Cheiro 1} & $\mathrm{PR}^{\bullet}$ & 9 & 2,33 & 0,250 & & \\
\hline & $\mathrm{PR}^{\bullet \bullet}$ & 55 & 1,45 & 0,252 & & \\
\hline & $\mathrm{PR}^{\bullet}$ & 9 & 1,00 & 0,000 & & \\
\hline \multirow[t]{2}{*}{ PI 152225} & $\mathrm{PR}^{\bullet \bullet}$ & 50 & 1,24 & 0,186 & & \\
\hline & $\mathrm{PMS}^{\bullet}$ & 9 & 2,78 & 0,194 & & \\
\hline \multirow[t]{2}{*}{ Pimenta Doce IH-1761 } & $\mathrm{PMS}^{\bullet \bullet}$ & 55 & 2,56 & 0,250 & & \\
\hline & $\mathrm{PMS}^{\bullet}$ & 9 & 2,67 & 0,250 & & \\
\hline \multirow[t]{2}{*}{ Pimenta Índio } & $\mathrm{PMS}^{\bullet \bullet}$ & 60 & 2,63 & 0,236 & & \\
\hline & $\mathrm{TS}^{\bullet}$ & 9 & 5,00 & 0,000 & & \\
\hline \multirow[t]{2}{*}{ Magali R } & $\mathrm{TS}^{\bullet \bullet}$ & 40 & 5,00 & 0,000 & & \\
\hline & $\mathrm{TS}^{\bullet}$ & 9 & 5,00 & 0,000 & & \\
\hline \multirow[t]{2}{*}{ Margarita } & $\mathrm{TS}^{\bullet \bullet}$ & 40 & 5,00 & 0,000 & & \\
\hline & $\mathrm{F}_{1}^{\bullet}$ & 9 & 2,44 & 0,278 & & \\
\hline Pim. Doce IH-1761 x & $\mathrm{F}_{1}^{\bullet \bullet}$ & 50 & 1,74 & 0,196 & & \\
\hline \multirow[t]{2}{*}{ Pim. Cheiro 1} & $\mathrm{~F}_{2}^{\bullet \bullet}$ & 522 & 1,47 & 0,346 & 35,5 & $-1,70^{\wedge}$ \\
\hline & $\mathrm{F}_{1}^{\bullet}$ & 9 & 1,78 & 0,194 & & \\
\hline Pimenta Índio $\mathrm{x}$ PI & $\mathrm{F}_{1}^{\bullet \bullet}$ & 55 & 1,73 & 0,202 & & \\
\hline \multirow[t]{3}{*}{152225} & $\mathrm{~F}_{2}^{\bullet \bullet}$ & 540 & 1,56 & 0,417 & & $-3,53^{\wedge}$ \\
\hline & $\mathrm{RCPR}^{\bullet \bullet}$ & 106 & 1,32 & 0,296 & 50,4 & \\
\hline & $\mathrm{F}_{1}^{\bullet}$ & 9 & 1,00 & 0,000 & & \\
\hline \multirow{2}{*}{$\begin{array}{l}\text { Pimenta Doce IH-1761 } \\
\text { x PI } 152225\end{array}$} & $\mathrm{~F}_{1}^{\bullet \bullet}$ & 55 & 1,18 & 0,151 & & \\
\hline & $\mathrm{F}_{2}^{\bullet \bullet}$ & 470 & 1,43 & 0,361 & 49,0 & $-2,73^{\wedge}$ \\
\hline
\end{tabular}

'Resultados obtidos em fevereiro de 2002 (primeira avaliação) - na obtenção da geração $\mathrm{F}_{1}$.

- Resultados obtidos em setembro de 2002 (segunda avaliação) - na obtenção da geração $F_{2}$.

^ Ganho de seleção superestimado, calculado em função de $\mathrm{h}^{2}$ no sentido amplo.

1. PR - Progenitor resistente, PMS - progenitor moderadamente suscetível, RC PR retrocruzamento, TS - Testemunha suscetível 
Tabela 11. Estimativas dos valores da heterose ( $\mathrm{H}$ e $\mathrm{H} \%$ ) e de efeitos da epistasia (C) com significância pelo teste t. C. chinense. 2003

\begin{tabular}{|c|c|c|c|c|}
\hline \multirow{2}{*}{\multicolumn{2}{|c|}{ Cruzamentos }} & \multicolumn{3}{|c|}{ Estimativas de } \\
\hline & & $\mathbf{H}$ & H\% & C \\
\hline \multirow[t]{4}{*}{ Pim. Doce IH-1761 x Pim. Cheiro 1} & $\mathrm{~F}_{1}^{\bullet}$ & $-0,11 \mathrm{~ns}$ & $-4,3$ & \\
\hline & $\mathrm{F}_{1}^{\bullet \bullet}$ & $-0,26 * * *$ & $-13,0$ & \\
\hline & $\mathrm{F}_{2}^{\bullet \bullet}$ & & & $-0,40 * * *$ \\
\hline & $\mathrm{F}_{1}^{\bullet}$ & $-0,05 n s$ & $-2,7$ & \\
\hline \multirow[t]{4}{*}{ Pimenta Índio x PI 152225} & $\mathrm{~F}_{1}^{\bullet \bullet}$ & $-0,20 * * *$ & $-10,4$ & \\
\hline & $\mathrm{F}_{2}^{\bullet \bullet}$ & & & $-0,27 * * *$ \\
\hline & $\mathrm{RCPR}^{\bullet \bullet}$ & & & $-0,16^{*}$ \\
\hline & $\mathrm{F}_{1}^{\bullet}$ & $-0,89 * * *$ & $-47,1$ & \\
\hline \multirow[t]{2}{*}{ Pimenta Doce IH-1761 x PI 152225} & $\mathrm{~F}_{1}^{\bullet \bullet}$ & $-0,72 * * *$ & $-37,9$ & \\
\hline & $\mathrm{F}_{2}^{\bullet \bullet}$ & & & $-0,11 *$ \\
\hline $\begin{array}{l}\text { * Significância com base no teste t a } 5^{\circ} \\
\text { probabilidade; }+ \text { entre e } 5 \% \text { e } 10 \% \text { de proba }\end{array}$ & $\begin{array}{l}\text { de probal } \\
\text { lidade; } n s\end{array}$ & $\begin{array}{l}\mathrm{e} ; * * 1 \% \mathrm{de} \\
\text { ignificativo. }\end{array}$ & babilidad & \\
\hline 'Resultados obtidos em fevereiro de 2002 & rimeira ava & - na obtençã & geração & \\
\hline
\end{tabular}



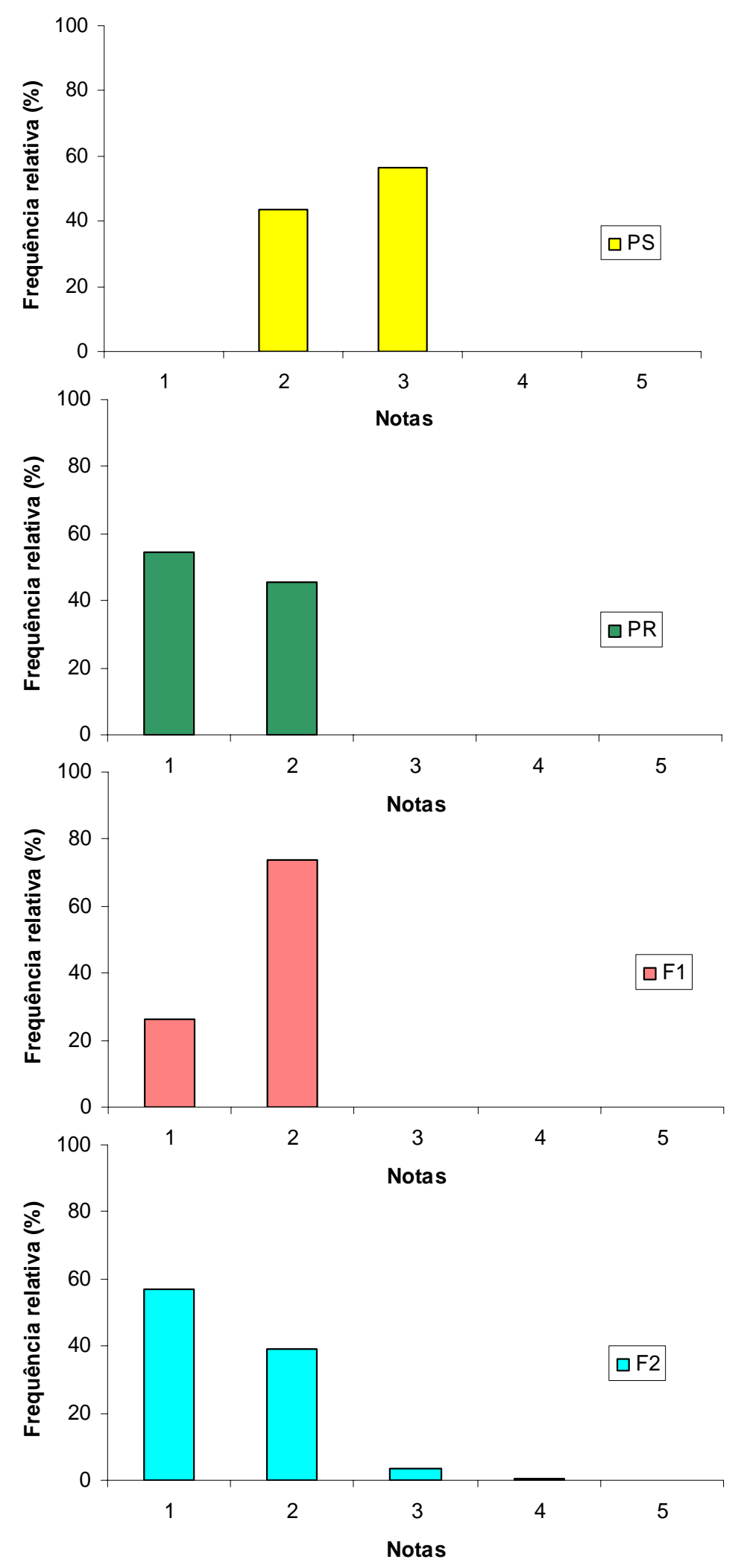

Figura 2 - Histograma de distribuição de freqüência do número de plantas em cada classe de notas nas gerações $\mathrm{P}_{\mathrm{R}}, \mathrm{P}_{\mathrm{MS}}, \mathrm{F}_{1}, \mathrm{~F}_{2}$ para o cruzamento Pim. Doce IH1761 x Pim. Cheiro 1. C. chinense. 2003 

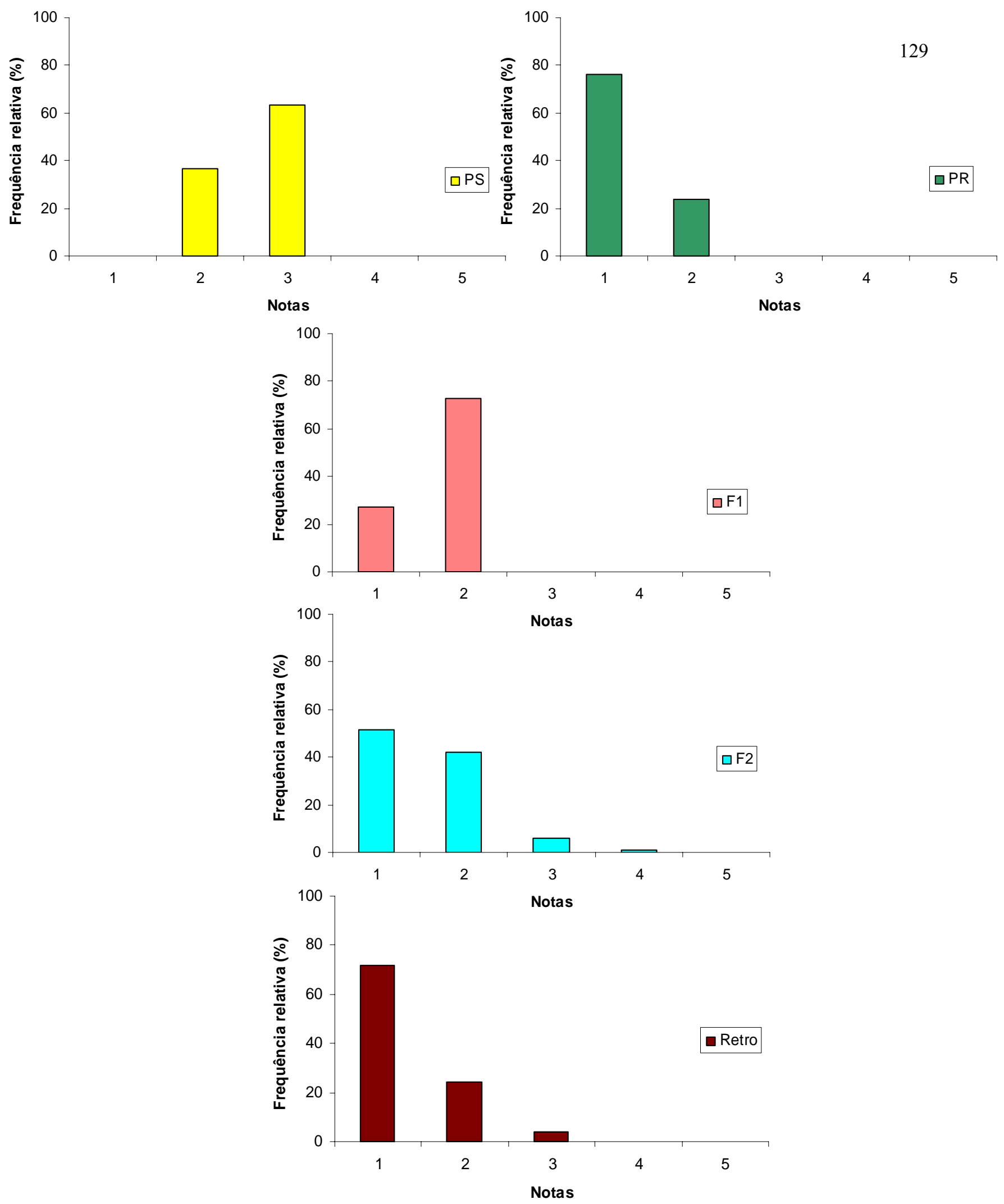

Figura 3 - Histograma de distribuição de freqüência do número de plantas em cada classe de notas nas gerações $\mathrm{P}_{\mathrm{R}}, \mathrm{P}_{\mathrm{MS}}, \mathrm{F}_{1}, \mathrm{~F}_{2}$ para o cruzamento Pimenta Índio x PI 152225. C. chinense. 2003 

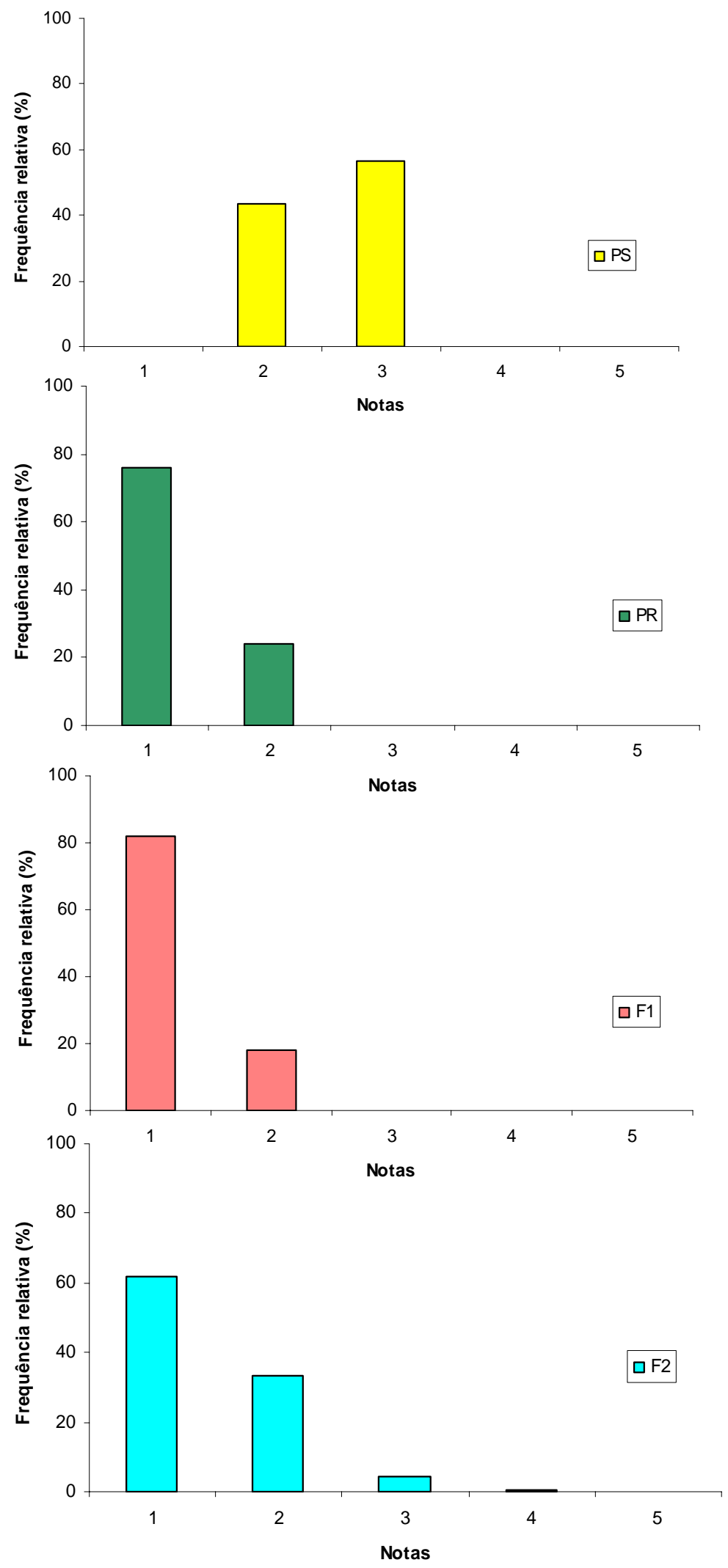

Figura 4 - Histograma de distribuição de freqüência do número de plantas em cada classe de notas nas gerações $\mathrm{P}_{\mathrm{R}}, \mathrm{P}_{\mathrm{MS}}, \mathrm{F}_{1}, \mathrm{~F}_{2}$ para o cruzamento Pimenta Doce IH-1761 x PI 152225. C. chinense. 2003 


\subsubsection{Reação de híbridos de pimenta resistentes ao oídio em $C$. chinense}

A principal característica observada nesta espécie e também em C. baccatum foi a reação de hipersensibilidade através de defoliação, já mencionada no item 5.3.2.1. Este mecanismo observado em todos os progenitores e gerações seguintes ocorre em condições de alta pressão de inóculo adjacente e representa o tipo de mecanismo de resistência expressado para essas espécie na presença do patógeno. Acredita-se que este mecanismo seja fisiológico e associado a produção de etileno induzida pela presença do patógeno. Este tipo de mecanismo se comparado ao da fonte HV-12 de C. annuum é bem distinto, pois este na presença de fontes de oídio não permite sua penetração e apresenta grande retenção foliar. As fontes de resistência encontradas na espécie $C$. chinense demonstram ter uma herança do tipo horizontal onde a forte restrição e redução da esporulação, o pequeno número de lesões e o longo período de latência foram sintomas marcantes e que caracterizam esse tipo de resistência.

Os progenitores, gerações $F_{1}$ e $F_{2}$ mantiveram suas reações apenas com pequenas variações nos valores, nas duas avaliações (Tabelas 12 e 13). Essas pequenas variações são normais e de natureza ambiental caracterizadas pelas avaliações em anos diferentes. A característica primordial para se dar início a um programa de melhoramento de resistência ao oídio é identificar e distinguir as reações de cada acesso ou híbrido de maneira adequada: resistentes variando entre notas 1 e 2, moderadamente suscetível com nota 3 e suscetível, notas 4 e 5 . Um outro fator de fundamental importância quando se pratica seleção visando resistência, é a pressão de inoculo utilizada nos experimentos, devendo ser igual, na mesma proporção em todas as etapas do programa de melhoramento.

As gerações $F_{2}$ derivadas tanto de cruzamentos entre progenitores resistentes versus suscetíveis quanto de resistentes versus resistentes resultaram na ocorrência de indivíduos transgressivos em relação aos progenitores. No caso dos cruzamentos entre progenitores resistentes, enquanto os progenitores se classificaram entre as notas 1 e 2 , a geração $\mathrm{F}_{2}$ apresentou plantas com notas de 1 a 5 (Tabela 12, Figuras 5 à 7)).

Quando se cruzou dois progenitores resistentes, observou-se nos três cruzamentos que tanto a média da geração $F_{1}$, como da $F_{2}$ foram relativamente superiores a médias de 
seus respectivos progenitores. Quando essas médias foram comparadas pelo teste $t$, verificou-se que elas não têm diferenças significativas, mostrando que essas diferenças são de natureza ambiental e não genética, indicando que a herança não é tão complexa e que há certa relação alélica entre os progenitores. Para o cruzamento Habanera x Pimenta Cheiro Laranja, a média da geração $F_{1}$ foi de 1,55 e a média dos pais de 1,43, sem diferenças; a média da geração $F_{2}$ observada foi de 1,60 e a esperada seria de 1,49, também em diferenças estatísticas. O mesmo ocorreu para o cruzamento Habanera x PI 152225, onde média do híbrido foi 1,38 enquanto a dos progenitores foi de 1,28, na geração $\mathrm{F}_{2}$ observada em estufa a média foi de 1,43, enquanto a esperada seria de 1,33. Para o cruzamento Santarem \#50 x PI 152225 apesar das diferenças numéricas nas médias, estas não diferiram estatisticamente, sendo a média da geração $F_{1}$ foi 1,33 e a dos progenitores 1,22 , em $F_{2}$ a média observada foi de 1,32 e a esperada seria de 1,27, (Tabela 13).

Essa semelhança estatística entre as médias, mostrou que não houve manifestação de heterose e nem de efeitos epistáticos significativos nas gerações dos cruzamentos. Portanto com base nos sintomas de reação de resistência apresentados pelos progenitores como reação de hipersensibilidade com defoliação e ausência e manifestação de heterose e epistasia apresentadas para os cruzamentos, pode-se concluir que os sistemas genéticos dos progenitores em questão são semelhantes.

Esses resultados indicam que seria interessante se desenvolver o primeiro híbrido de pimenta $C$. chinense resistente ao oídio, o que seria inédito mercado de pimentas. Como os dois progenitores seriam resistentes para oídio poderíamos com o híbrido estar agregando vigor em produtividade, homeostase, precocidade e combinar características de frutos e qualidade. A seleção para características desejáveis nos progenitores, como tipos de frutos, cores, seria muito importante visando obtenção de combinações para a demanda do segmento de pimentas.

A espécie Capsicum chinense é uma pimenta tropicalizada, adaptada as regiões Norte, Nordeste e regiões do Caribe. O uso de híbridos resistentes ao oídio poderia ser uma alternativa para o cultivo intensivo em estufas de plástico ou telado, ambientes favoráveis quanto à ocorrência de oídio. 
Tabela 12. Número de plantas em cada classe, de acordo com a escala de notas para resistência a Leveillula taurica em condições de casa de vegetação. C. chinense. 2003

\begin{tabular}{|c|c|c|c|c|c|c|}
\hline Gerações $^{1}$ & & $\begin{array}{c}\mathbf{R} \\
\text { Nota } 1\end{array}$ & $\begin{array}{c}\text { MR } \\
\text { Nota } 2\end{array}$ & $\begin{array}{c}\text { MS } \\
\text { Nota } 3\end{array}$ & $\begin{array}{c}\text { S } \\
\text { Nota } 4\end{array}$ & $\begin{array}{c}\text { AS } \\
\text { Nota } 5\end{array}$ \\
\hline & $\mathrm{PR}^{\bullet}$ & 9 & 0 & 0 & 0 & 0 \\
\hline \multirow{2}{*}{ Habanera } & $\mathrm{PR}^{\bullet \bullet}$ & 30 & 15 & 0 & 0 & 0 \\
\hline & $\mathrm{PR}^{\bullet}$ & 0 & 9 & 0 & 0 & 0 \\
\hline \multirow[t]{2}{*}{ Pimenta Cheiro Laranja } & $\mathrm{PR}^{\bullet \bullet}$ & 23 & 27 & 0 & 0 & 0 \\
\hline & $\mathrm{PR}^{\bullet}$ & 9 & 0 & 0 & 0 & 0 \\
\hline \multirow[t]{2}{*}{ PI 152225} & $\mathrm{PR}^{\bullet \bullet}$ & 38 & 12 & 0 & 0 & 0 \\
\hline & $\mathrm{PR}^{\bullet}$ & 5 & 4 & 0 & 0 & 0 \\
\hline \multirow[t]{2}{*}{ Santarem $\# 50$} & $\mathrm{PR}^{\bullet \bullet}$ & 36 & 9 & 0 & 0 & 0 \\
\hline & $\mathrm{TS}^{\bullet}$ & 0 & 0 & 0 & 0 & 9 \\
\hline \multirow[t]{2}{*}{ Magali R } & $\mathrm{TS}^{\bullet \bullet}$ & 0 & 0 & 0 & 0 & 40 \\
\hline & $\mathrm{TS}^{\bullet}$ & 0 & 0 & 0 & 0 & 9 \\
\hline \multirow[t]{2}{*}{ Margarita } & $\mathrm{TS}^{\bullet \bullet}$ & 0 & 0 & 0 & 0 & 40 \\
\hline & $\mathrm{F}_{1}^{\bullet}$ & 3 & 6 & 0 & 0 & 0 \\
\hline \multirow{3}{*}{ Habanera x Pimenta Cheiro Laranja } & $\mathrm{F}_{1} \bullet \bullet$ & 9 & 11 & 0 & 0 & 0 \\
\hline & $\mathrm{F}_{2}{ }^{\bullet \bullet}$ & 277 & 193 & 50 & 5 & 2 \\
\hline & $\mathrm{F}_{1}^{\bullet}$ & 9 & 0 & 0 & 0 & 0 \\
\hline \multirow[t]{3}{*}{ Habanera x PI 152225} & $\mathrm{~F}_{1} \bullet \bullet$ & 31 & 19 & 0 & 0 & 0 \\
\hline & $\mathrm{F}_{2} \bullet \bullet$ & 346 & 145 & 29 & 7 & 0 \\
\hline & $\mathrm{F}_{1}^{\bullet}$ & 9 & 0 & 0 & 0 & 0 \\
\hline \multirow{2}{*}{ Santarem \#50 x PI 152225} & $\mathrm{~F}_{1} \bullet \bullet$ & 20 & 10 & 0 & 0 & 0 \\
\hline & $\mathrm{F}_{2}^{\bullet \bullet \bullet}$ & 289 & 78 & 9 & 4 & 4 \\
\hline
\end{tabular}

•Resultados obtidos em fevereiro de 2002 (primeira avaliação) - na obtenção da geração $F_{1}$.

• Resultados obtidos em setembro de 2002 (segunda avaliação) - na obtenção da geração $F_{2}$.

1. $\quad \mathrm{PR}-$ Progenitor resistente, TS - Testemunha suscetível 
Tabela 13. Número total de plantas (n), estimativas de médias, variâncias, valores da heterose ( $\mathrm{H}$ e H\%) e epistasia (C) com significância pelo teste t. C. chinense, 2003

\begin{tabular}{|c|c|c|c|c|c|c|c|}
\hline Gerações & & $\mathbf{n}$ & Médias & Variâncias & $\mathbf{H}$ & $\mathrm{H} \%$ & C \\
\hline & $\mathrm{PR}^{\bullet}$ & 9 & 1,00 & 0,000 & & & \\
\hline \multirow{2}{*}{ Habanera } & $\mathrm{PR}^{\bullet \bullet}$ & 45 & 1,33 & 0,227 & & & \\
\hline & $\mathrm{PR}^{\bullet}$ & 9 & 2,00 & 0,000 & & & \\
\hline \multirow{2}{*}{ Pimenta Cheiro Laranja } & $\mathrm{PR}^{\bullet \bullet}$ & 50 & 1,54 & 0,253 & & & \\
\hline & $\mathrm{PR}^{\bullet}$ & 9 & 1,00 & 0,000 & & & \\
\hline \multirow{2}{*}{ PI 152225} & $\mathrm{PR}^{\bullet \bullet}$ & 50 & 1,24 & 0,186 & & & \\
\hline & $\mathrm{PR}^{\bullet}$ & 9 & 1,33 & 0,250 & & & \\
\hline \multirow[t]{2}{*}{ Santarem $\# 50$} & $\mathrm{PR}^{\bullet \bullet}$ & 45 & 1,20 & 0,164 & & & \\
\hline & $\mathrm{TS}^{\bullet}$ & 9 & 5,00 & 0,000 & & & \\
\hline \multirow[t]{2}{*}{ Magali R } & TS $\bullet \bullet$ & 40 & 5,00 & 0,000 & & & \\
\hline & $\mathrm{TS}^{\bullet}$ & 9 & 5,00 & 0,000 & & & \\
\hline \multirow[t]{2}{*}{ Margarita } & $\mathrm{TS}^{\bullet \bullet}$ & 40 & 5,00 & 0,000 & & & \\
\hline & $\mathrm{F}_{1}^{\bullet}$ & 9 & 1,67 & 0,250 & $0,17 \mathrm{~ns}$ & 11,3 & \\
\hline Habanera $x$ Pimenta & $\mathrm{F}_{1}^{\bullet \bullet}$ & 20 & 1,55 & 0,353 & $0,12 \mathrm{~ns}$ & 8,4 & \\
\hline \multirow{2}{*}{ Cheiro Laranja } & $\mathrm{F}_{2}^{\bullet \bullet}$ & 527 & 1,60 & 0,533 & & & $0,11 \mathrm{~ns}$ \\
\hline & $\mathrm{F}_{1}^{\bullet}$ & 9 & 1,00 & 0,000 & $0,00 \mathrm{~ns}$ & 0,0 & \\
\hline \multirow{3}{*}{ Habanera x PI 152225} & $\mathrm{~F}_{1} \bullet^{\bullet}$ & 50 & 1,38 & 0,240 & $0,10 \mathrm{~ns}$ & 7,8 & \\
\hline & $\mathrm{F}_{2} \bullet \bullet$ & 527 & 1,43 & 0,435 & & & $0,10 \mathrm{~ns}$ \\
\hline & $\mathrm{F}_{1}^{\bullet}$ & 9 & 1,00 & 0,000 & $-0,16 n s$ & $-13,8$ & \\
\hline Santarem $\# 50 \quad x \quad P I$ & $\mathrm{~F}_{1} \bullet$ & 30 & 1,33 & 0,230 & $0,11 \mathrm{~ns}$ & 9,0 & \\
\hline 152225 & $\mathrm{~F}_{2}^{\bullet \bullet}$ & 384 & 1,32 & 0,454 & & & $0,05 \mathrm{~ns}$ \\
\hline
\end{tabular}

* Significância com base no teste t a 5\% de probabilidade; ns- não significativo.

- Resultados obtidos em fevereiro de 2002 (primeira avaliação) - na obtenção da geração $F_{1}$.

• Resultados obtidos em setembro de 2002 (segunda avaliação) - na obtenção da geração $F_{2}$.

1. PR - Progenitor resistente, TS - Testemunha suscetível 

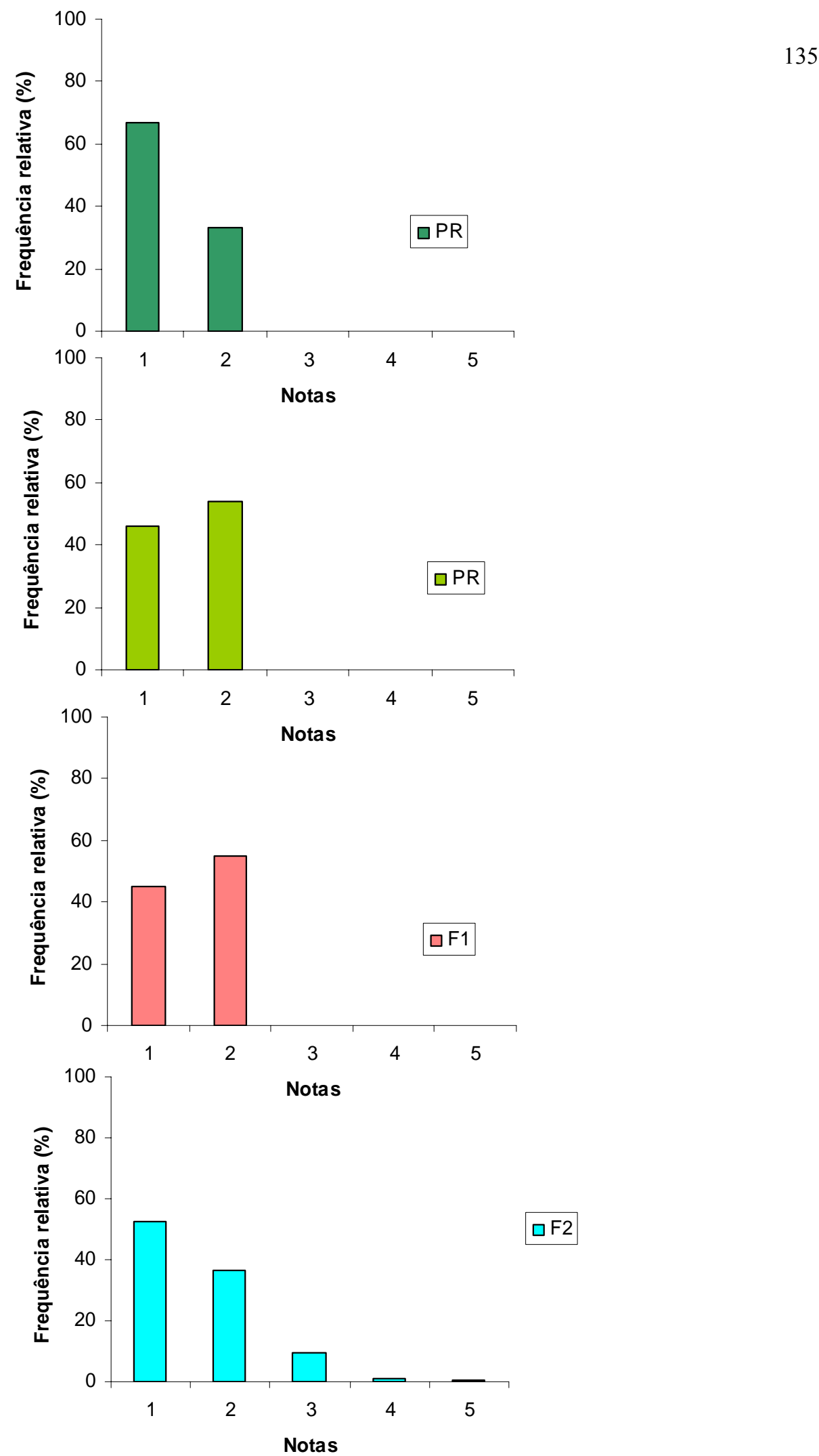

Figura 5 - Histograma de distribuição de freqüência do número de plantas em cada classe de notas nas gerações $P_{R}, P_{R}, F_{1}, F_{2}$ para o cruzamento Habanera $x$ Pimenta Cheiro Laranja. C. chinense. 2003 

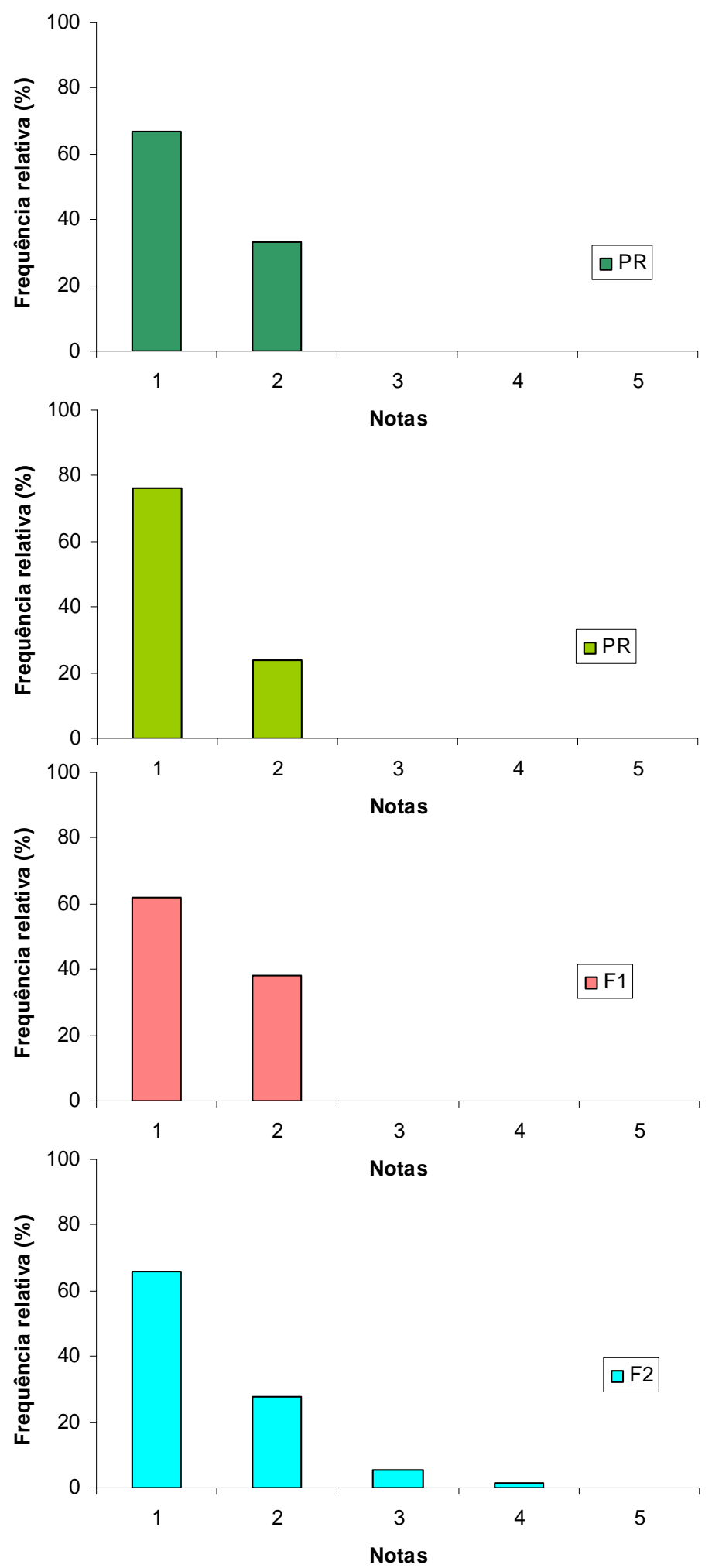

Figura 6 - Histograma de distribuição de freqüência do número de plantas em cada classe de notas nas gerações $\mathrm{P}_{\mathrm{R}}, \mathrm{P}_{\mathrm{R}}, \mathrm{F}_{1}, \mathrm{~F}_{2}$ para o cruzamento Habanera x PI 152225 C. chinense. 2003 


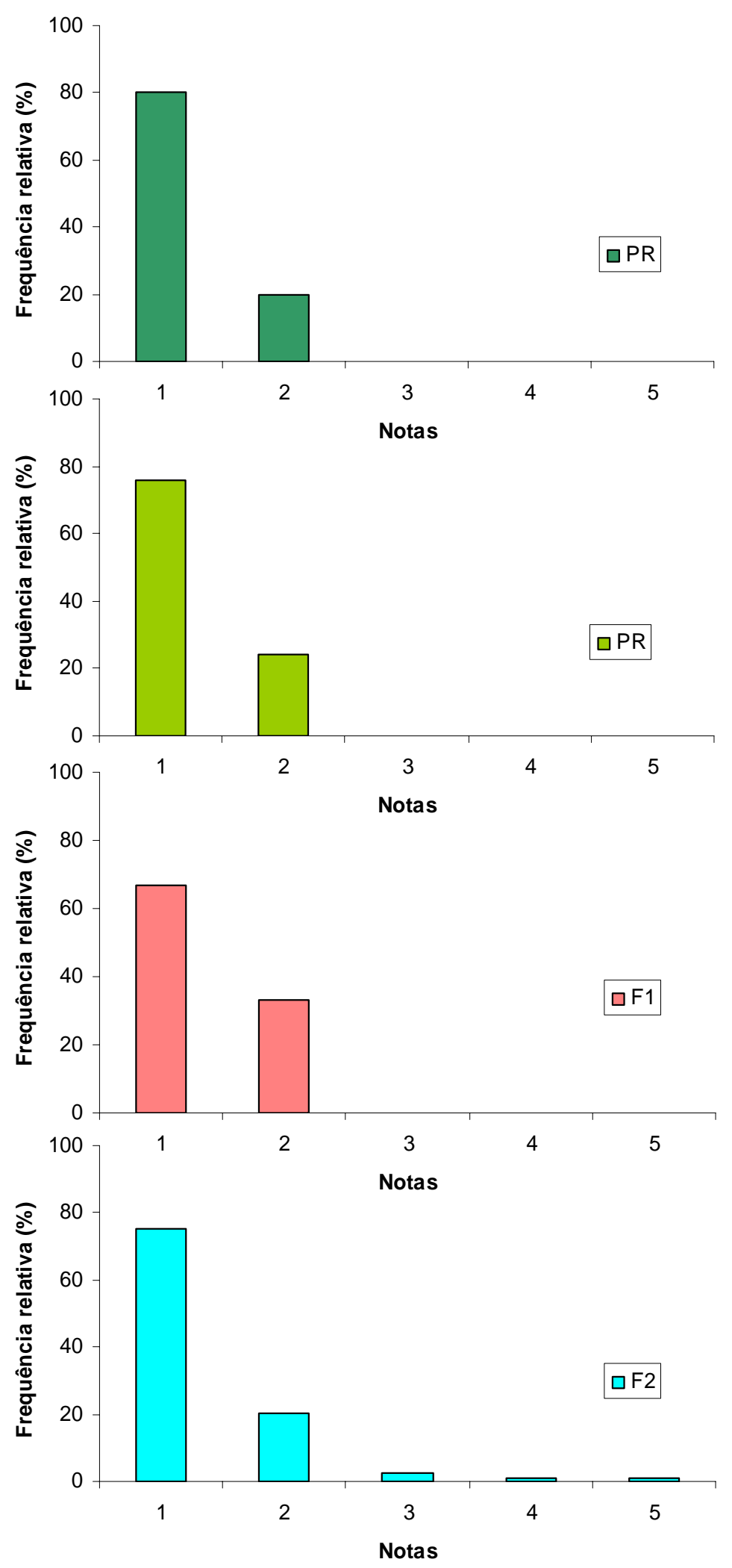

Figura 7 - Histograma de distribuição de freqüência do número de plantas em cada classe de notas nas gerações $P_{R}, P_{R}, F_{1}, F_{2}$ para o cruzamento Santarem \#50 x PI 152225. C. chinense. 2003 


\subsection{Conclusões}

- Dentre os acessos triados, 85\% foram resistentes ao oídio. Apenas os acessos Pimenta Índio, Pimenta Doce IH-1761 e Pimenta Doce IH-1763 apresentaram-se como moderadamente suscetíveis.

- Uma intensa defoliação, como resultado de uma reação de hipersensibilidade ao fungo foi característica marcante na expressão de resistência tanto dos progenitores quanto das suas gerações.

- Os resultados da análise genética indicaram que houve manifestação de dominância e de epistasia na expressão da resistência, em todos os cruzamentos realizados. Constatou-se envolvimento de variâncias aditivas, dominantes e epistáticas.

- A presença de indivíduos transgressivos na geração $F_{2}$ indicou uma herança poligênica.

- Os valores de herdabilidades e ganhos de seleção foram moderados, numa amplitude de $35,5 \%$ à $50,4 \%$ e de $1,70 \%$ à $3,53 \%$ respectivamente.

- As reações apresentadas pelas gerações obtidas nos cruzamentos entre progenitores resistentes e a análise genética mostraram que os genótipos desses progenitores têm o mesmo sistema genético que controla a resistência, não indicando diferenças alélicas. 


\section{CONCLUSÕES GERAIS}

- A porcentagem de acessos resistentes identificada nas espécies $C$. baccatum e $C$. chinense foi contrastante a de C. annuum. Em C. annuum esta proporção foi de apenas 5\% enquanto em C. baccatum foi de $84 \%$ e em C. chinense de $85 \%$.

- A fonte HV-12 teve um tipo de mecanismo de resistência diferenciado. Apresentou uma forte resistência a penetração do patógeno e uma alta retenção foliar, enquanto as demais fontes de C. annuum, C. baccatum e C. chinense mostraram uma de reação de hipersensibilidade ao patógeno com conseqüente defoliação.

- A herança da resistência ao oídio em Capsicum mostrou ser poligênica. Em Capsicum annuum pelo menos quatro pares de genes governam a herança, enquanto em $C$. baccatum de dois a seis pares de genes segregantes mostraram-se envolvidos e em $C$. chinense a segregação em $\mathrm{F}_{2}$ com indivíduos transgressivos indicam que a herança também é poligênica.

- A ação gênica envolvida para a maioria dos cruzamentos de C. annuum, C. baccatum e C. chinense envolveram as variâncias aditivas, dominantes e epistáticas. A diferença foi que em $C$. annuum estas estimativas caracterizaram uma herança recessiva e em $C$. baccatum e C. chinense dominante.

- Os valores de herdabilidade foram altos indicando boas perspectivas no progresso de seleção para todas as espécies de Capsicum. Em Capsicum annuum o progresso observado na geração $F_{3}$ confirmou a eficiência seletiva para resistência ao oídio.

- Os sistemas genéticos dos progenitores resistentes em Capsicum annuum possuem diferentes mecanismos genéticos e expressões de resistência. Enquanto em C. baccatum e $C$. chinense os mecanismos de resistência mostraram serem similares, havendo alelismo entre as fontes. 
ANEXOS 
Anexo A. Resumo da análise de variância da reação dos acessos da coleção de Capsicum ao oídio (Leveillula taurica).

\begin{tabular}{lcccccc}
\hline Fontes de & & G.L. & & \multicolumn{3}{c}{ Quadrados Médios } \\
Variação & C. annuum & C. chinense & C. baccatum & C. annuum & C. chinense & C. baccatum \\
\hline Blocos & 3 & 3 & 3 & $0,0057^{\mathrm{NS}}$ & $0,0192^{\mathrm{NS}}$ & $0,0125^{\mathrm{NS}}$ \\
Acessos & 22 & 20 & 35 & $0,2811^{* *}$ & $0,1232^{* *}$ & $0,2975^{* *}$ \\
Erro & 66 & 60 & 105 & 0,0985 & 0,0853 & 0,0866 \\
CV\% & & & & 9,91 & 12,07 & 11,83 \\
\hline
\end{tabular}

(NS) Não significativo, ao nível de 5\% de probabilidade, pelo teste de F.

(**) Significativo, ao nível de $1 \%$ de probabilidade, pelo teste F.

Anexo B. Escala de notas de 1 à 5 de acordo com os níveis de severidade ao oídio.

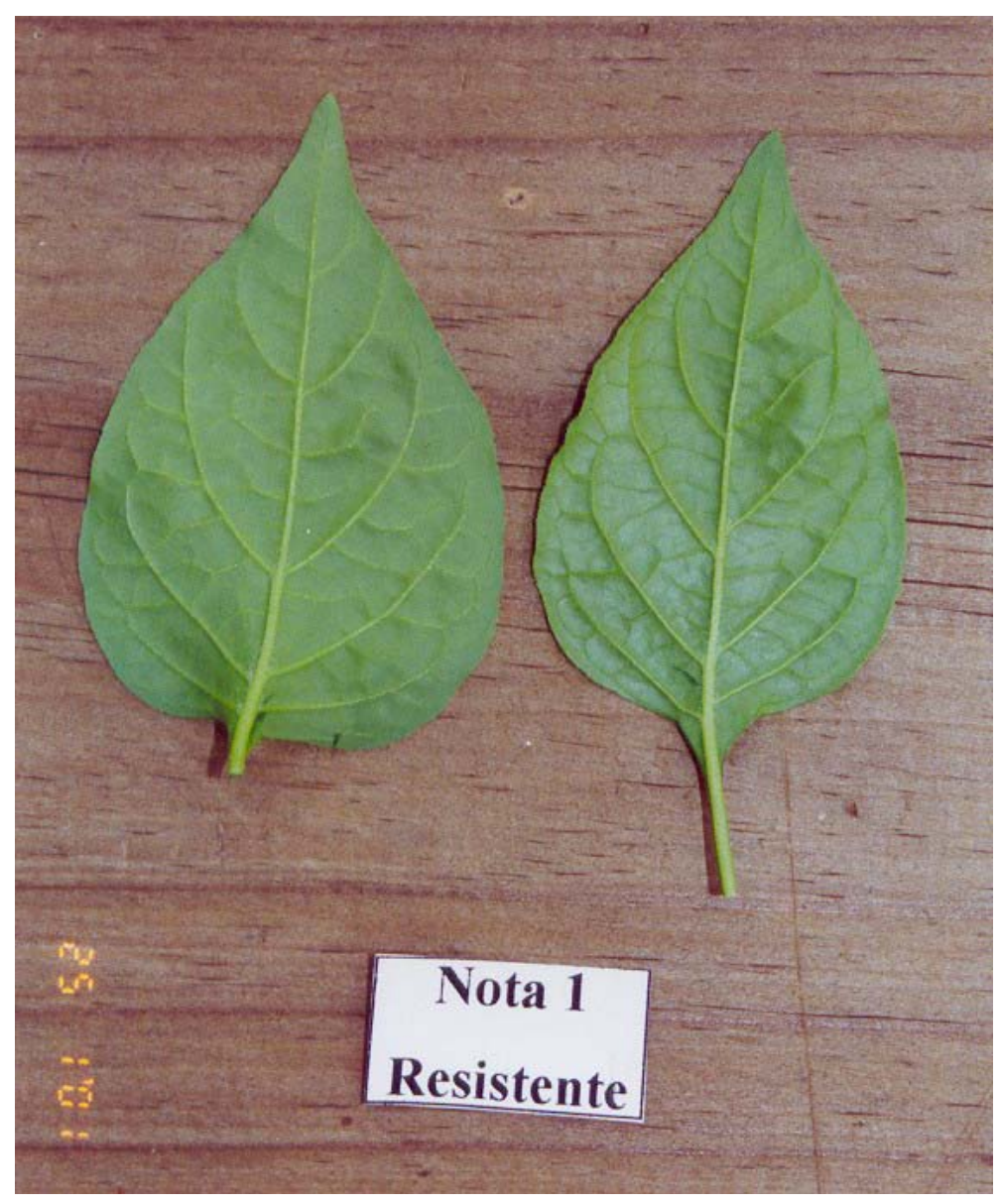



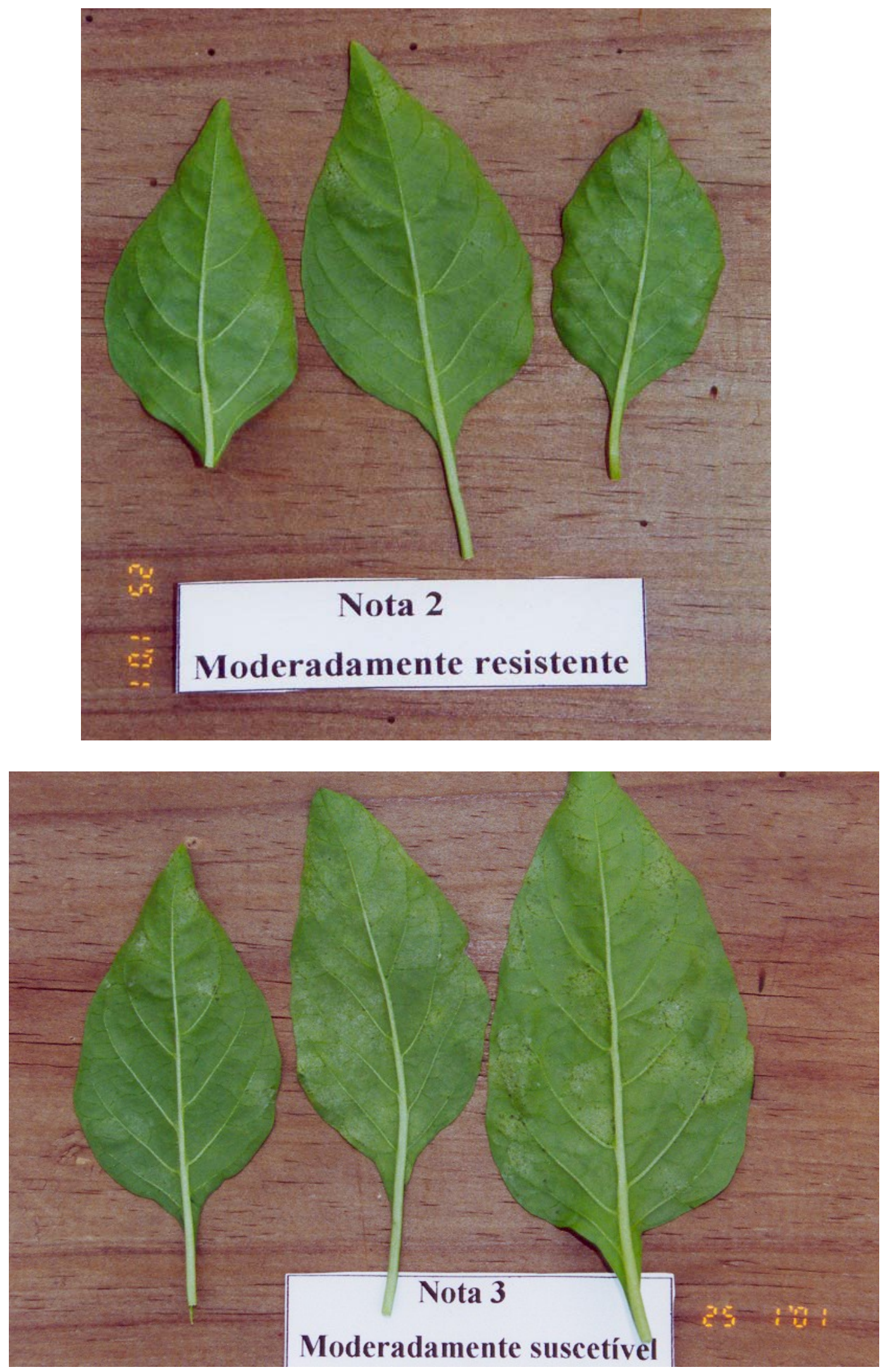

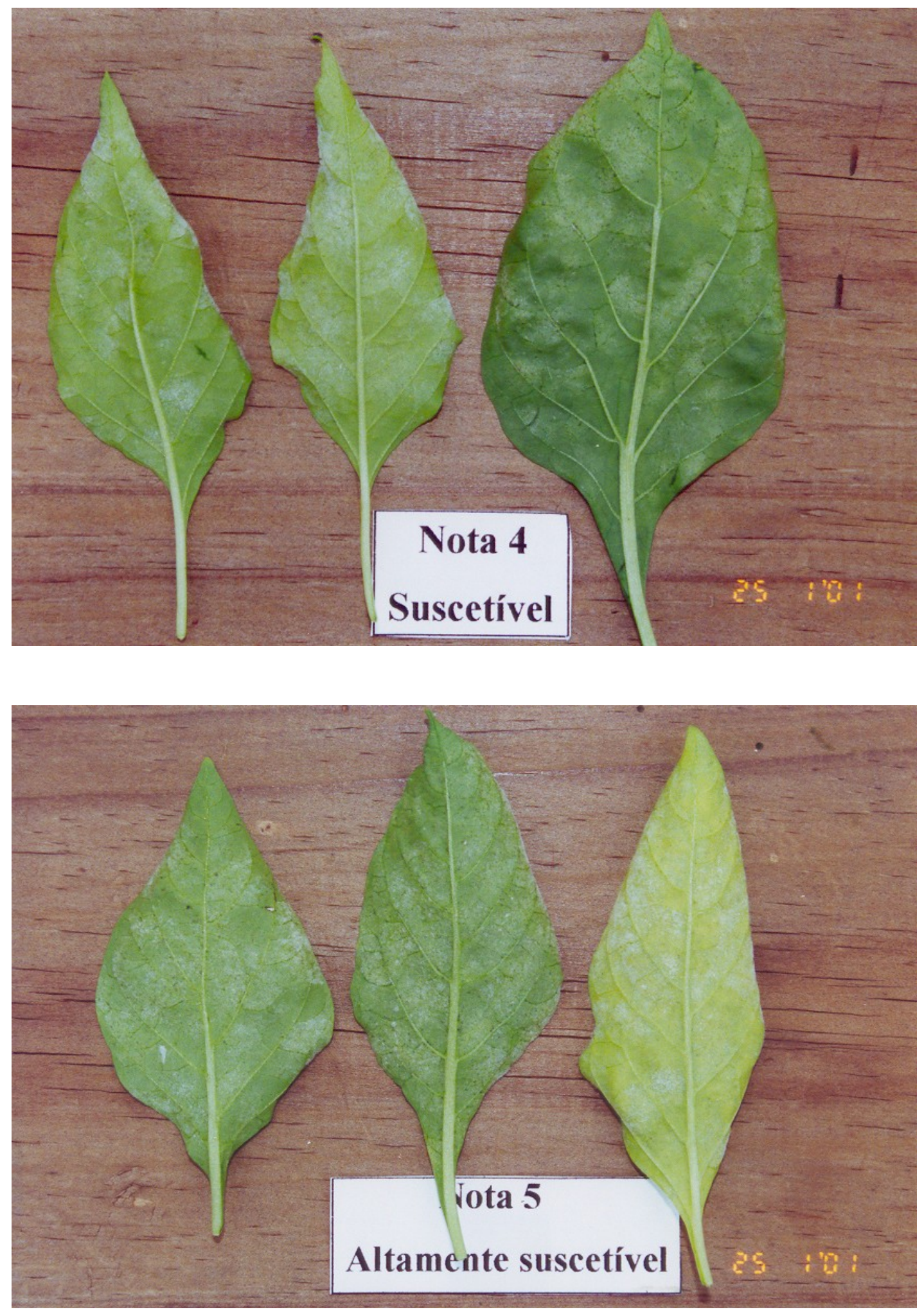
Anexo C. Segregação para tipos de frutos na geração $F_{2}$.
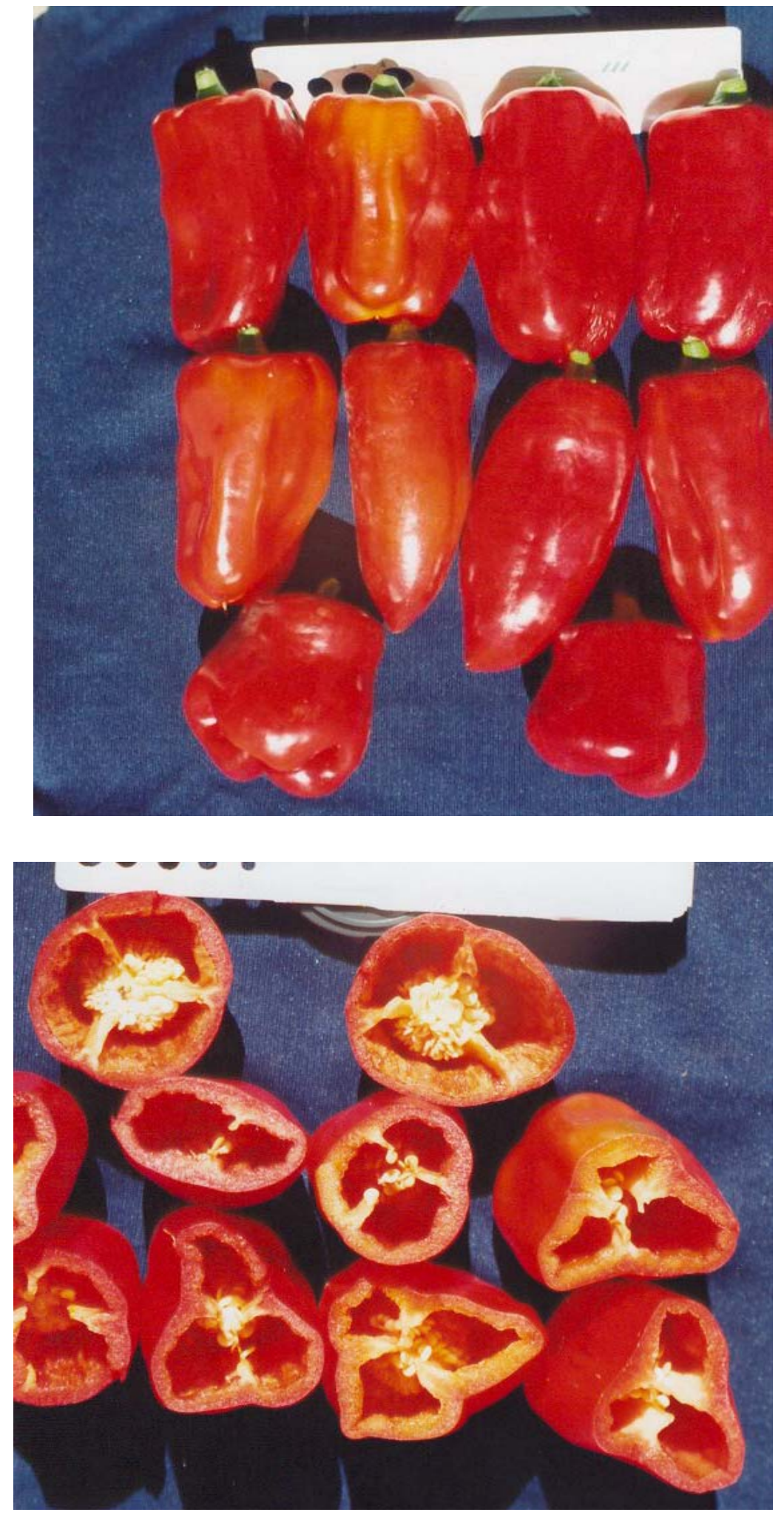
Anexo D. Reações ao oídio: a esquerda Magali R (altamente suscetível), no centro HV12 (resistente) e a direita Chilli (resistente com manchas cloróticas - “fleck”).

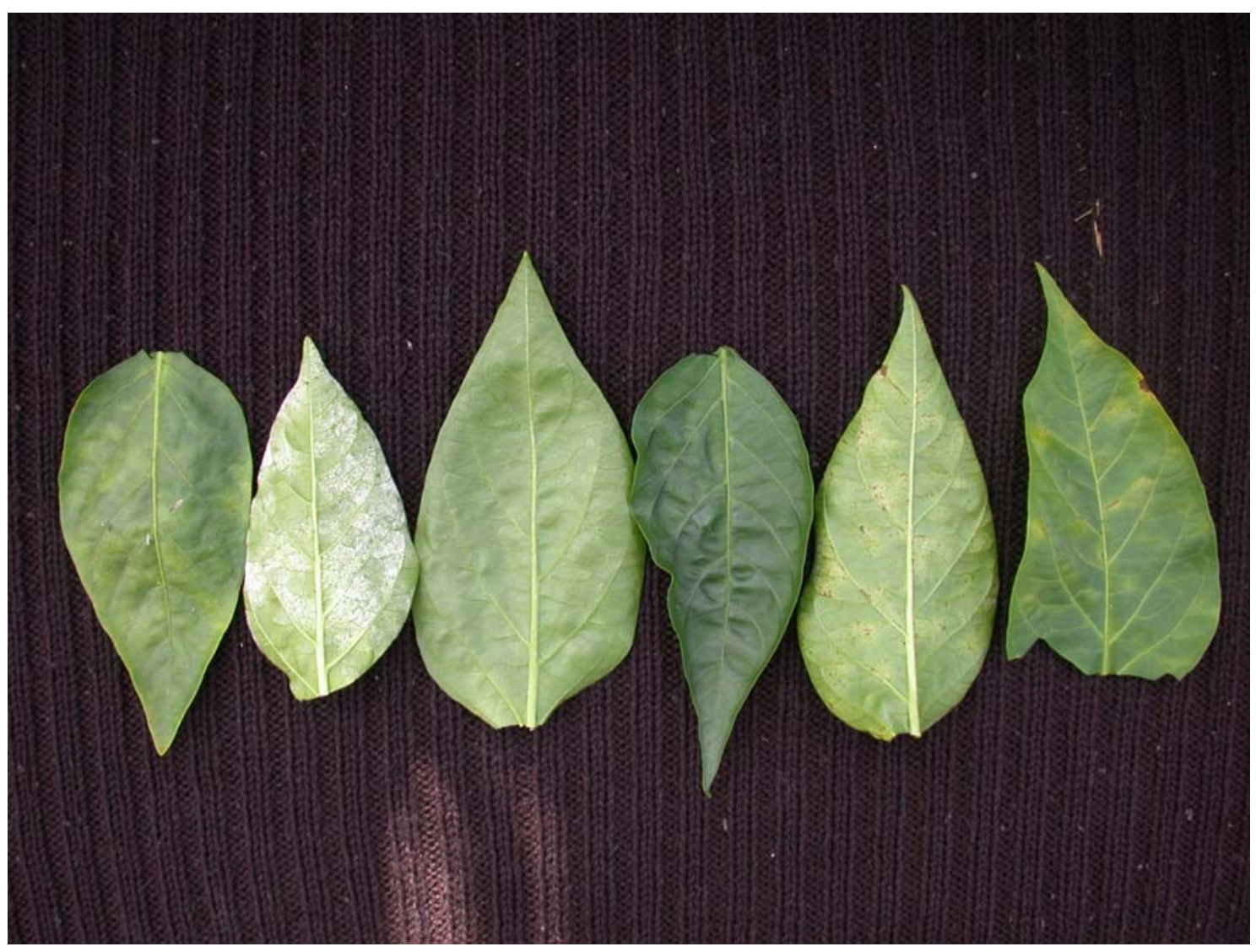


Anexo E. Sintoma de oídio em Capsicum chinense.

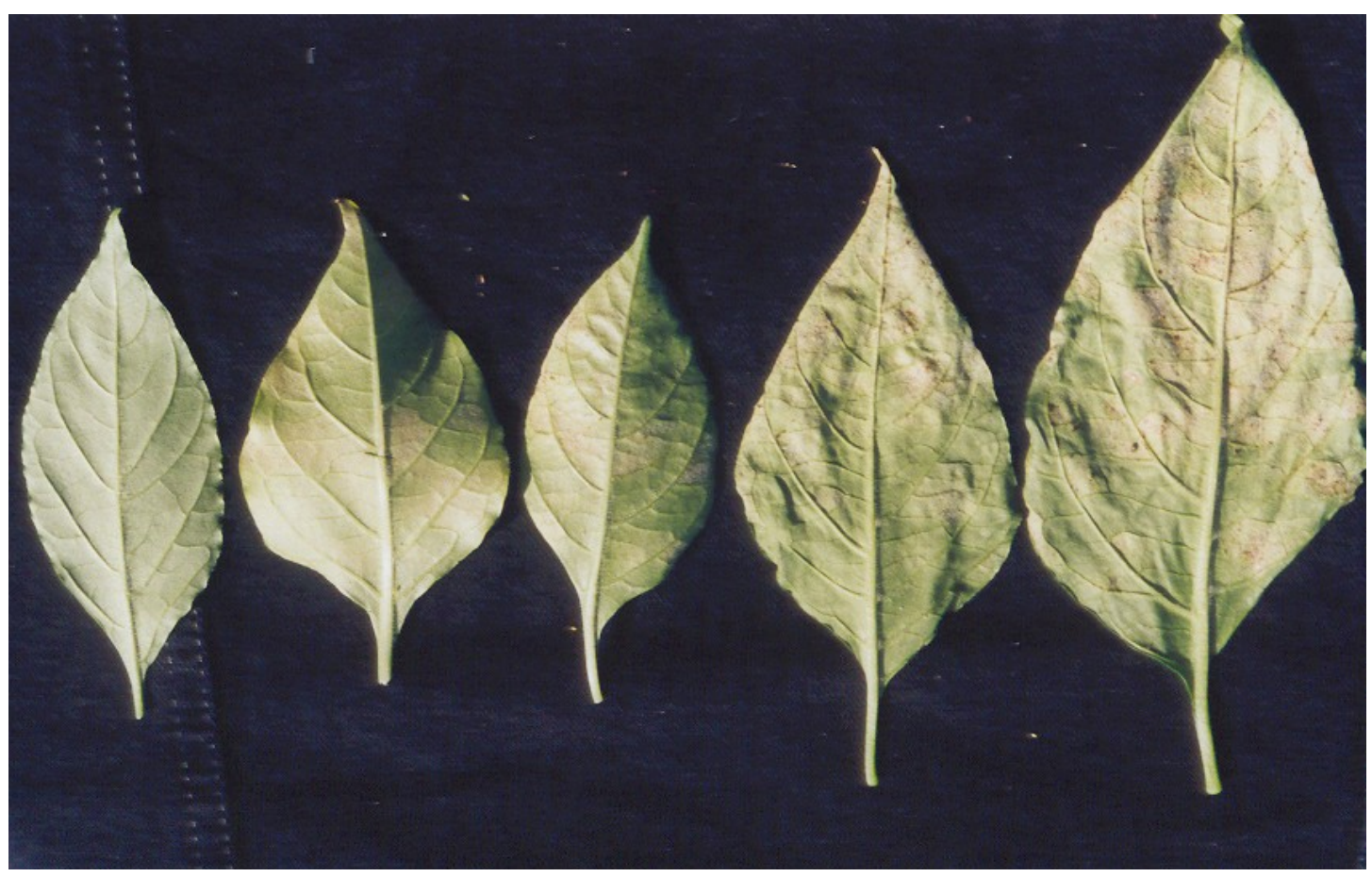

Anexo F. Desfolha em Capsicum chinense.

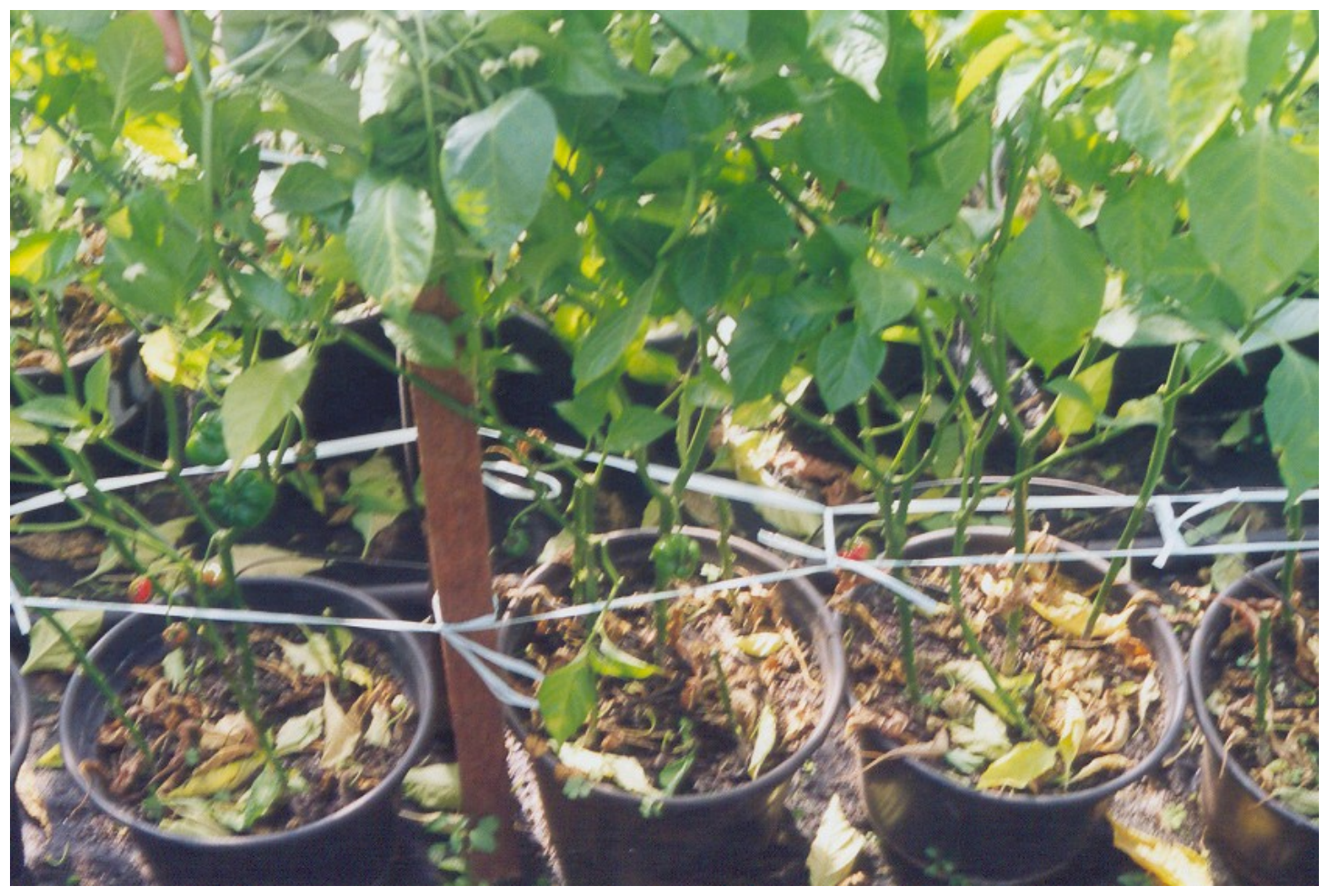




\section{REFERÊNCIAS BIBLIOGRÁFICAS}

AHMED, A.E.; ELJACK, A.E.; SULIMAN, M.E.; MOHAMED, Y.F. Evaluation of hot peppers (Capsicum annuum L.) local gerplasm for powdery mildew (Leveillula taurica (lev.) arn.) resistance in the Sudan. (Compact disc). Sudan Journal of Agricultural Research, v.1, n.1, p.53-55, 1998.

AMORIM, L. Colonização e reprodução. In: BERGAMIN FILHO, A.; KIMATI, H; AMORIN, L. (Ed). Manual de Fitopatologia, princípios e conceitos. São Paulo: Agronômica Ceres, 1995. p. 316-319.

ANAND, N.; DESPHANDE, A.A.; SRIDHART, T.S. Resistance to powdery mildew in a accession of Capsicum frutescens and its inheritance pattern. Capsicum and Eggplant Newsletter, v.6, p.77-78, 1987.

BECHIR, A.M. Evaluation of pepper genotypes to Leveillula taurica Lev. (Arn.) resistance in Tunisia. Capsicum and Eggplant Newsletter, v.12, p.81-82, 1993.

BERGAMIN FILHO, A., KIMATI, H., AMORIM L. Manual de fitopatologia: princípios e conceitos. 3 ed. São Paulo: Ceres, v.1, 1995. 919p.

BERTÃO, M.R. Evolução Cariotípica no gênero Capsicum (Solanaceae). Piracicaba, 1993. 148p. Dissertação (Mestrado) - Escola Superior de Agricultura "Luiz de Queiroz”, Universidade de São Paulo.

BIDARI, V.B.; BHAT, B.N.; HEDGE, R.K. Reaction of different genotypes of chilli against Leveillula taurica (Lev.) Arn. Indian Journal of Agricultural Science, v.55, n.9, p.557-559, 1985.

BLANCARD, D.; ROUXEL, F.; LAFON, R. Endermidades de las hortaliças. Madrid: Ed. Mundi-Prensa, 1995. 576p. 
BLAT, S.F.; COSTA, C.P; SALA, F.C. Reação de pimentão e pimenteiras à Leveillula taurica. Horticultura Brasileira, v.20, n.2, p.346, 2002. Suplemento 1.

BLAZQUEZ, C.H. A powdery mildew of chilli caused by Oidiopsis sp. Phytopathology, v.66, p.1155-1157, 1976.

BOITEUX, L.S.; CUPERTINO, F.P.; SILVA, C.; DUSI, A.N.; MONTE-NESHICH, D.C. Resistance to potato vírus Y (pathotype 1-2) in Capsicum annuum and Capsicum chinense is controlled by two independent major genes. Euphytica, v.87, p.53-58, 1996.

BRAUN, U. The genus Leveillula taurica - A preliminary study. Nova Hedwigia, v.32, p.565-583. 1980.

BURTON, G.M. Quantitative inheritance in pearl millet (Penisetum glaucum). Agronomy Journal., v.43, p.409-417, 1951.

CAFÉ FILHO, A.C.; COELHO, M.V.S.; SOUZA, V.L. Oídios em hortaliças. In: STADINIK, M.J., RIVERA, M.C (Ed.). Oídios. Jaguariúna, Embrapa Meio Ambiente, p. 285-302, 2001.

CARVER, T.L.W.; ZEYEN, R.J.; LYNGKJAER, M.F. Plant cell defences to powdery mildew of Graminae. Aspects of Apllied Biology, v.42, p. 257-266, 1995.

CERKAUSKAS, R.F. First report of powdery mildew of greenhouse pepper caused by Leveillula taurica in British Columbia, Canada. Plant Disease, v.87, p.1151, 2003.

CERKAUSKAS, R.F.; BROWN, J.; FERGUSON, G.; KHOSLA, S. First report of powdery mildew of greenhouse pepper caused by Leveillula taurica in Canada. Plant Disease, v.83, n.8, p.781,1999.

CHANDER, M.S. Biochemical properties associated with resistance to powdery mildew in chillies. Plant Disease Research, v.9, n.1, p.103-104, 1994.

CNPH, Projeto Capsicum. Hortaliças. http://www.cnph.embrapa.br/projetos/capsicum/index.html, 2001.

CORRELL, J.C.; GORDON, T.R.; ELLIOTT, V.J. Host range, specificity, and biomatrical measurements of Leveillula taurica in California. Plant Disease, v.71, n.3, p.248-251, 1987.

COSTA, C.P. Melhoramento de Hortaliças. Piracicaba: Fealq, 1977. 319p. (Apostila). 
CUARTERO, J.S. Breeding new tomato cultivars for protected cultivation in winter climates. In: COCKSHULL, K.E.; TUZEL, Y.; GUL, A. Acta Horticulturae, n.366, p.209-220,1999. /Second symposium on protected cultivation of solanaceae in mild winter climates. Netherlands/.

DAMICONE, J.P.; SUTHERLAND, A.J. First report of pepper powdery mildew caused by Leveillula taurica in Oklahoma. Plant Disease, v.83, p. 1072, 1999.

DAUBEZE, A.M.; HENNART, J.W., PALLOIX, A. Resistance to taurica in pepper (Capsicum annuum) is ologogenically controled and stable in Mediterranean regions. (Compact disc). Plant Breeding, v.114, v.4, p.327-332, 1995.

DAUBEZE,A.M.; POCHARD, E.; PALLOIX. Inheritance of resistance to Leveillula taurica and relation to other phenotypic characters in the haplodiploid progeny issued from na African pepper line. (Compact disc) Eucarpia VIIth meeting on genetics and breeding on capsicum and eggplant, 27-30, p.229-32, 1989.

ECHER, M.de M. Reação de pimentão (Capsicum annuum L.) a Phytophthora capsici e Potato Vírus Y (PVY ${ }^{\mathrm{m}}$ ). Piracicaba, 2001. 62p. Tese (Doutorado) - Escola Superior de Agricultura “Luiz de Queiroz”, Universidade de São Paulo.

FAO. FAOSTAT - Database Results. URL: http://apps.fao.org/Lim500/nph?Production.crops.Primary\&Domain=Sua. Fao Org (abr. 1999).

GOMES, F.P. Curso de estatística experimental. 13. ed. Piracicaba: Nobel, 1990. 467p.

KUABARA, M.Y. Reação de abobrinha (Cucurbita moschata Duchesne) ao vírus do mosaico da melancia raça-1 (WMV-1). Piracicaba, 1984. 69p. Dissertação (Mestrado) - Escola Superior de Agricultura "Luiz de Queiroz”, Universidade de São Paulo.

LIMA, M.L.P Resistência genética e aspectos epidemiológicos, fisiológicos e anatômicos da infecção de Oidiopsis taurica em Capsicum spp. Brasília, 2002. 130p. Dissertação (Mestrado) - Instituto de Biociências, Universidade de Brasília.

MATHER, K.; JINKS, J.L. Biometrical genetics. 3. ed. Greath Britain: Butler \& Tanner, 1981. 382p. 
MATHER, K.; JINKS, J.L. Introdução à genética biométrica. São Paulo, Sociedade Brasileira de genética, 1984. 242p.

MC LEOD, M.J.; GUTTMAN, S.I.; ESHBAUGH, W.H. Early evolution of chille peppers (Capsicum). Economic Botany., v.36, n.4, p.361-368, 1982

MOLOT, P.M., LECOQ, H. Les Oidiums des Cucurbitacées. Données bibliographiques. Travaux préliminairees. Agronomie, v. 6, p. 355-362, 1986.

MOLOT, P.M.; LEROUX, J.P.; DIOP-BRUCKLER, M. Leveillula taurica (Lev.) Arn: Culture axenique, biologie et spécificité parasitaire. Agronomie, v.10, p. 551-559, 1990.

MULGE, R.; ANAND, N. Identification of sweet pepper (Capsicum annuum L.) lines to develop $\mathrm{F}_{1}$ hybrids resistant to powdery mildew. The Indian Journal of Genetics \& Plant Breeding, v. 57, n.2, p.193-199, 1997.

MUNEEM, K.C.; VERMA, S.K.; PANT, K.C. Performance of some chillies against leaf spot, powdery mildew and fruit rot in Kumaon Hills. Indian Phytopathology, v.48, n.2, p.206, 1995.

MURTHY, H.M.K.; DESHPANDE, A.A. Studies on genetics of powdery mildew (Leveillula taurica (Lév.) Arn.) resistance in chilli (Capsicum annuum L.). Vegetable_Science, v.24, n.2, p. 127-131, 1997.

NAGAI, H. Melhoramento de pimentão (Capsicum annuum L.) visando resistência ao vírus Y. Horticultura Brasileira, v.1, n.2, p.3-9, 1983.

NOUR, M.A. Studies on Leveillula taurica (Lév.) Arn. and other powdery mildews. Transactions of the British Mycological Society. V.41, p.17-38, 1958.

NUEZ, F.; ORTEGA, R.G.; COSTA. J. El cultivo de pimentos, chiles y ajies. Madrid: Mundi-Prensa, 1996. 607p.

PALLOIX, A. Disease of pepper and perspectives for genetic control. In: EUCARPIA MEETING ON GENETICS AND BREEDING ON CAPSICUM AND EGGPLANT, 8., Meeting Rome, 1992. p. 120-126.

PALTI, J. The Leveillula mildews. Botanical Review, v.54, p.423-535, 1988.

REIFSCHNEIDER, F.J.B. Capsicum: Pimentas e pimentões no Brasil. Brasília: Embrapa, 2000. 113p. 
REIFSCHNEIDER, F.J.B.; RIBEIRO, C.S.C.; LOPES, C.A. Pepper production and breeding in Brazil, and a Word on eggplants. Capsicum and Eggplant Newsletter, v.17, p.13-18, 1998.

REUVENI, R., ROTEM, J. Epidemics of Leveillula taurica on tomatoes and peppers as affected by conditions of humidity. Phytopathologische Zeitschrift., v.76, p.153157, 1973.

REUVENI, R.; PERL, M. Peroxidase isoenzyme specificity in abscission zone fragments of pepper leaves affected by powdery mildew or stress condition. Phytopathologische Zeitschrift, v.96, p.208-214, 1979.

REUVENI, R.; PERL, M.; ROTEM, J. The effectt of Leveillula taurica on leaf abscission in peppers. Phytopathologische Zeitschrift, v.80, p.79-84, 1974.

REUVENI, R.; PERL, M.; ROTEM, J. Inhibition of shedding of pepper leaves infected with powdery mildew (Leveillula taurica) by application of auxins. Phytoparasitica, v.4, p. 197-199, 1976.

RUSSELL, G.E. Characterisation of adult-plant resistance to yellow rust in wheat. In EUROPEAN AND MEDITERRANEAN CEREAL RUSTS CONFERENCE, 4., Proceedings Switzerland, 1976. p.21.

SEQUEIRA, L.; STEEVES, T.A. Auxin inactivation and its relation to leaf drop caused by the fungus Omphalia flavida. Plant Physiology, v.29, p.11-16. 1954.

SHIFRISS, C.; PILOWSKY, M.; ZACKS, J.M. Resistance to Leveillula taurica mildew (=Oidiopsis taurica) in Capsicum annuum. Phytoparasitica, v.20, n.4, p.279-283, 1992.

SINAGAGLIA， C.; COUTINHO, L.N.; CARVALHO, J.R.FIGUEIREDO, M.B. Primeira constatação do mildeo pulverulento do pimentão (Capsicum annuum) causado por Leveillula taurica (Erysiphaceae), um fungo pouco estudado no Brasil. Arquivos do Instituto de Biologia, v.62, p.57, 1995. (Suplemento).

SMITH, R.; KOIKE, S.T.; DAVIS. M.; SUBBARAO, K.; LAEMMLEN, F. Several fungicides control powdery mildew in peppers. California Agriculture, v.53, n.6, p.40-43, 1999. 
SOUZA, V.L. Epidemiologia e controle de oídio Oidiopsis taurica (Lév.) Salmon em genótipos de Capsicum. Brasília, 2000. 117p. Dissertação (Mestrado) - Instituto de Ciências Biológicas, Universidade de Brasília.

SOUZA, V.L.; CAFÉ FILHO, A.C. Efeito do estádio fenológico e da pressão de inóculo na reação de genótipos de Capsicum a Oidiopsis taurica, Fitopatologia Brasileira, v.25, p.404, 2000. (resumo).

SOUZA, V.L.; CAFÉ-FILHO, A.C. Resistance to Leveillula taurica in genus Capsicum. Plant Pathology, v.52, p.613-619, 2003.

STADNIK, M.J.; RIVERA, M.C. Oídios. Jaguariúna: Embrapa Meio Ambiente. 2001. 484p.

SUlINAM, M.E., BARDIN, M., DAUBÉZE, A.M., MOHAMED, Y.F., NICOT, P. Aggressiveness of Leveillula taurica on pepper. Capsicum and Eggplant Newsletter, v.18, p.83-86, 1999.

ULLASA, B.A.; RAWAL, R.D.; SOHI, H.S.; SINGH, D.P. Reaction of sweet pepper genotypes to Anthracnose, Cercospora leaf spot, and Powdery Mildew. Plant Disease, v.65, n.7, p.600-601, 1981.

VAN DER PLANK, J.C. Plant Diseases: epidemics and control. London: Academic Press, 1963. 349p.

VAN DER PLANK, J.E. Disease resistance in plants. New York: Academic Press, 1968. 206p.

VELÁSQUEZ, V.; VALLE G. First report of powdery mildew of pepper in NorthCentral Mexico. Plant Disease, v.83, n. 3, p.302, 1999.

VENCOVSKY, R.; BARRIGA, P. Genética biométrica no fitomelhoramento. Ribeirão Preto: Revista Brasileira de Genética, 1992. 496p.

WIESE, M.V.; DEVAY, J.E. Growth regulator changes in cotton associated with defoliation caused by Verticillium albo-atrum. Plant Physiology, v.45, p.304-309, 1970.

WILLIAMSON, C.E. Ethylene, a metabolic product of diseased or injured plants. Phytopathology, v.40, p.205-208, 1950. 
ZEYEN, R.J.; BUSHNELL, W.R.; CARVER, T.L.W.; ROBBINS, M.P.; CLARK, T.A.; BOYLES, D.A.; VANCE, C.P. Inhibiting phenylalanine ammonia lyase and cinnmayl alcohol dehydrogenase supresses Mla1 (HR) but not mlo5 barley powdery mildew resistances. Physiological and Molecular Plant Pathology, v.47, p.119140, 1995.

ZEWDIE, Y. International hot pepper trial network (Inthope) at Nazareth, Ethiopia. Capsicum and Eggplant Newsletter, v.13, p.40-43, 1994. 